

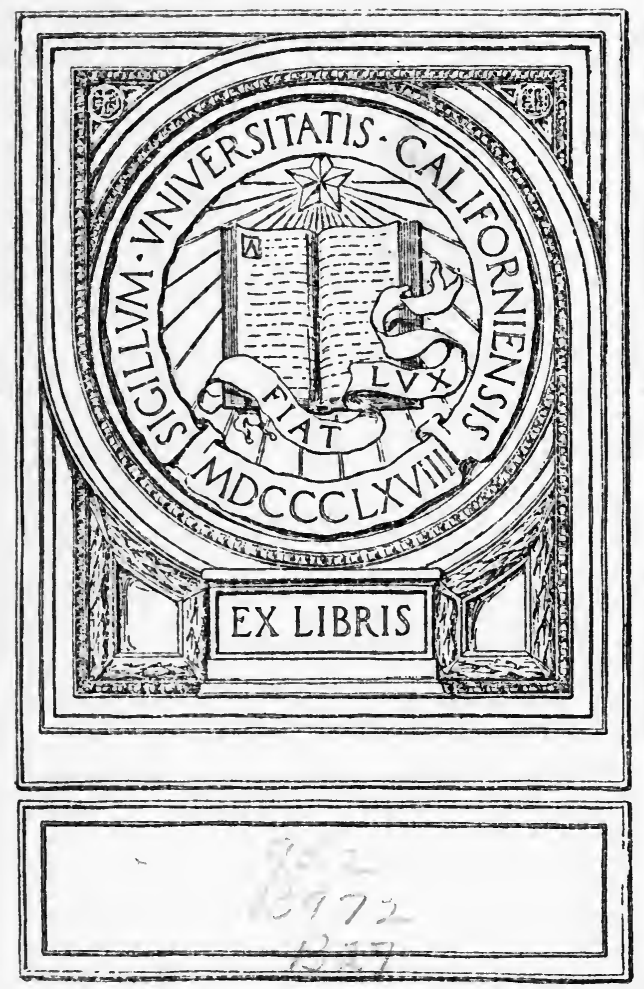



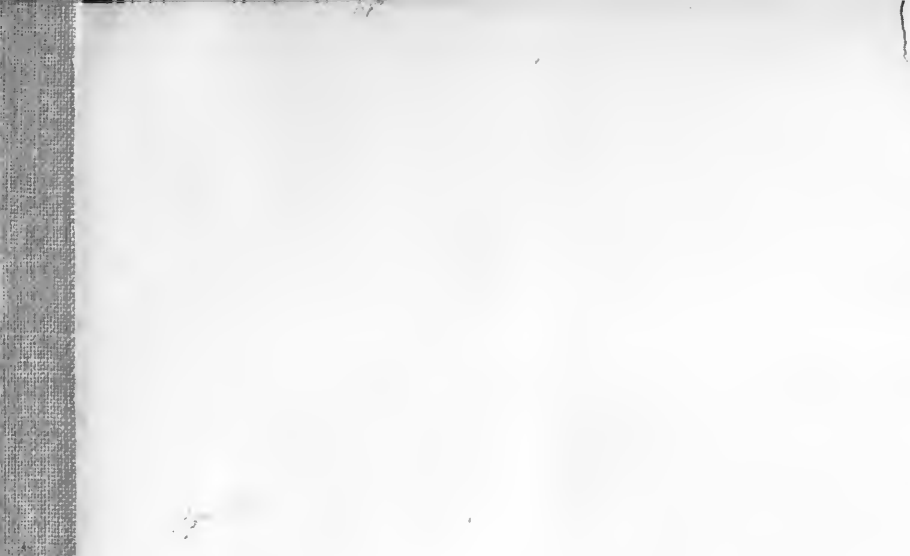

i.

s. 


\section{JOHN BURROUGHS BOY AND MAN}




\section{BOOKS BY THE SAME AUTHOR}

OUR FRIEND, JOHN BURROUGHS, Including Autobiographical Sketches by Mr. Burroughs

NURSING THE INSANE 



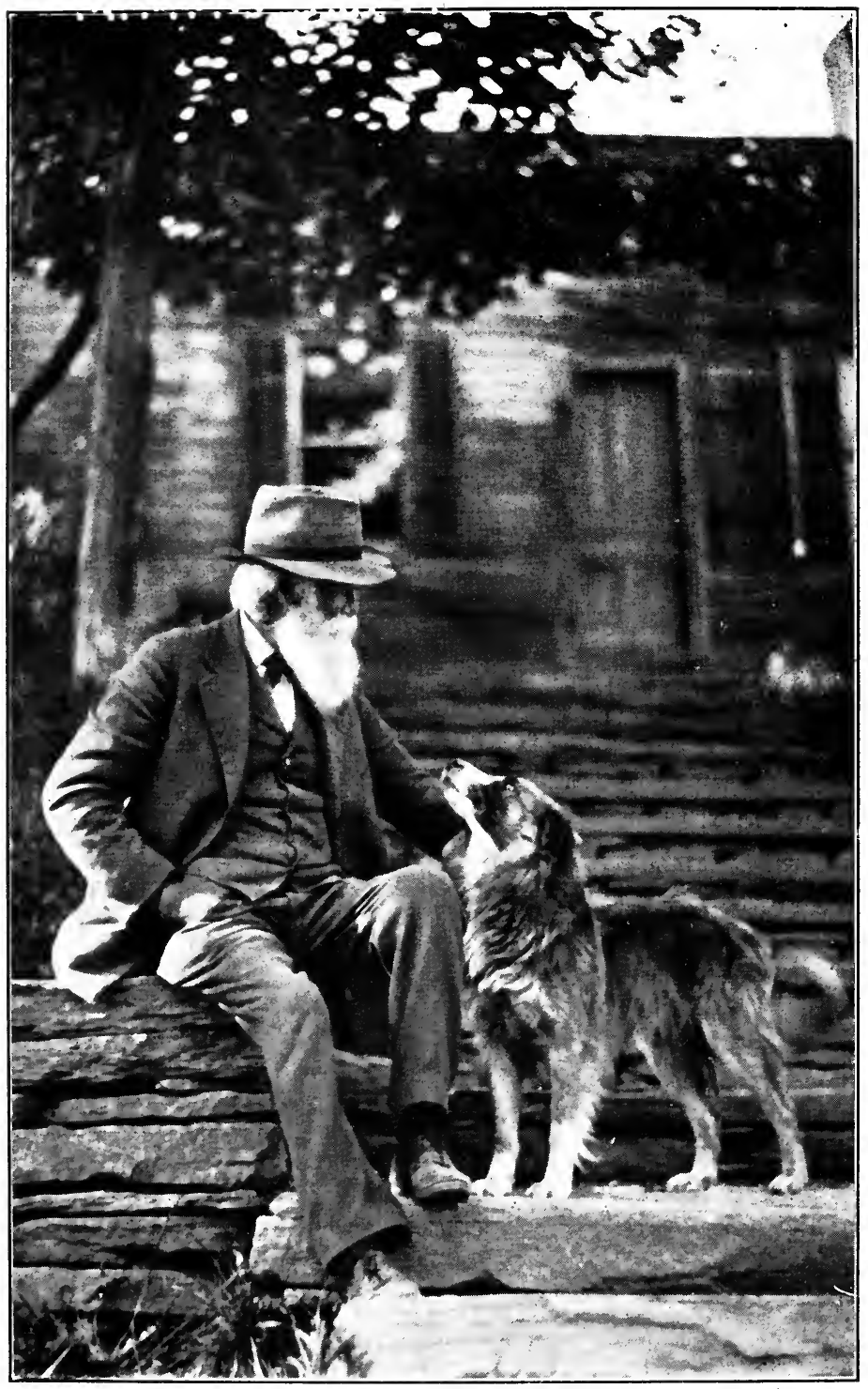

CHUMS

John Burroughs at his birthplace 


\title{
JOHN BURROUGHS
}

Boy and Man

\author{
BY \\ CLARA BARRUS, M.D.
}

AUTHOR OF

"OUR FRIEND, JOHN BURROUGHS"

WITH ILLUSTRATIONS FROM PHOTOGRAPHS AND COLOURED PLATES

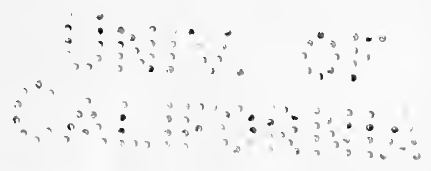

GARDEN CITY

NEW YORK DOUBLEDAY, PAGE \& COMPANY 1920 


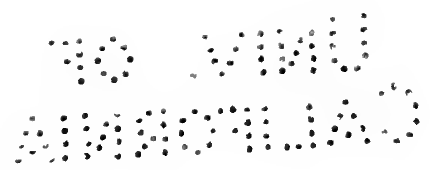

COPYRIGHT, 1920, BY

DOUBLEDAY, PAGE \& COMPANY

ALL RIGHTS RESERVED, INCLUDING THAT OF TRANSLATION INTO FOREIGN LANGUAGES, INCLUDING THE SCANDINAVIAN 


\section{PREFACE}

GIRLs and boys who read the books of John Burroughs, and grown-up girls and boys as well, usually decide that he would make a jolly outdoor companion, and many of them write and tell him so. They ask all sorts of questions about his youth - where he lived, what he did when he was a boy, what games he played, what sports he enjoyed, what books he read, what studies he liked best, how he came to know so much about birds and animals, and how he learned to write about them.

This book aims to answer such questions. It also aims to acquaint the reader with significant incidents and experiences in his boyhood and youth as well as to give a picture of him throughout adult life, and in his advanced years.

The incidents here related have been told me by $\mathrm{Mr}$. Burroughs himself, and are sanctioned by him. During the midsummer and fall for many years past I have wandered with him over the fields and hills and through the woods where he roamed as a boy. In these rambles he has pointed out the places where the narrated events occurred. He has explained in detail the curious and interesting ways and means of long ago-old-time ways which will never come again. And not only in his youthful haunts, but also during many an evening by the fireside at The Nest, he has again recounted the childish recollec- 
tions, the boyish pastimes, and the youthful dreams recorded here; furnishing me also with the information (or the records from which I could gather it) which has enabled me to picture his adult years before my personal acquaintance with him began.

This book was originally intended as a Boy's Life of John Burroughs, but as the work neared completion it seemed advisable to arrange it with a view to interesting grown-up boys and girls as well.

The Nest at Riverby, CLARA BARRUS

West Park, N. Y. 


\section{CONTENTS}

CHAPTER

PAGE

I. A GROWN-UP BoY • . . . . . . 3

II. JoHN's ForebEARS . • . . . . . 11

\section{CHILDHOOD}

III. Early Memories of Farm and HearthSTONE • • • • • • • • • • 25

BOYHOOD

IV. BoyHood Recollections . . . . . 45

V. Ways and Means in John's Boyhood . 65

VI. Chores and Pastimes . . . . . . 81

VII. More Chores and Pastimes . . . . 99

VIII. The Anti-Rent WAR . . . . . . 123

IX. SchOOL DAYS . . . . . . . .

YOUTH

X. Teacher and Student - . . . 165

XI. Student and Teacher $\cdot . \quad \cdot \quad \cdot \quad \cdot(201)$

XII. WORKING FOR UNCLE SAM . . . . 224 


\section{MATURITY}

XIII. STILL Working For UNCle SAM • • . 255

XIV. The Fruit FARMer . . • . • . 273

XV. Dog Friends ANd A Boy Chum • • 294

XVI. DAYS OFF • • • • • • • , . 307

XVII. WORK aNd Play IN Later Years • . 324

XVIII. WORK AND Play IN LATER Years (CONTINUED) • . • • • • • • 


\section{LIST OF ILLUSTRATIONS}

Chums

Frontispiece

FACING PAGE

A brigand steak in the beechwoods . . . . . . . . . 28

On the porch at Woodchuck Lodge . . . . . . . . . 28

Johnnie Burroughs and his friends . . . . . . . . . . 29

Where Johnnie learned his letters . . . . . . . . 36

"Baba" and the grandchildren on his boyhood rock . . . . 37

John Burroughs on the "Giant Stairs" . . . . . . . . 72

John Burroughs scattering corn for the chipmunks at Woodchuck

Lodge . . . . . . . . . . . . . . . . 73

A dog-churn . . . . . . . . . . . . . . 88

Sugar-making at Riverby . . . . . . . . . . . . 89

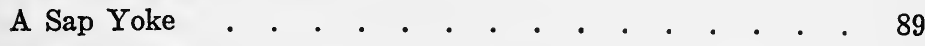

Planting a tree . . . . . . . . . . . . . 89

The West Settlement pupil taking honorary degree at Yale . . 184

The West Settlement Schoolhouse . . . . . . . . . 184

Slabsides . . . . . . . . . . . . . . . . . 185

The stone house at Riverby . . . . . . . . . . 185

The bark study and summer house . . . . . . . . 185

John Burroughs swimming in a mountain stream . . . . 200

Driving his car on the farm where he drove oxen as a boy . 200

The Nest at Riverby . . . . . . . . . . . . . 201

John Burroughs with Theodore Roosevelt in the Yellowstone . 312

In Yosemite with John Muir . . . . . . . . . . . 312

The Laird of Woodchuck Lodge . . . . . . . . . . 313

John Burroughs showing Edison glacier marks on the home farm. 328

Good-bye! . . . . . . . . . . . . . 329 



\section{JOHN BURROUGHS}

BOY AND MAN 


\section{MY DEAR Young FRIENDS:}

The most precious things of life are near at hand, without money and without price. Each of you has the whole wealth of the universe at your very doors. All that I ever had, and still have, may be yours by stretching forth your hand and taking it.

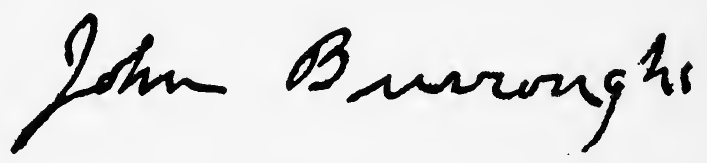




\section{JOHN BURROUGHS BOY AND MAN}

\section{CHAPTER I}

\section{A GROWN-UP BOY}

MARK TwaIN said of Thomas Bailey Aldrich in his later years: "I am tired of waiting for that fellow to grow old." Some men are like that. They keep the heart of a boy and snap their fingers in the face of Father Time. John Burroughs is such a man. Although he has lived on this round earth for more than eighty-three years, he is still getting fun out of life, and is as interested about the earth itself and all the creatures on it as when he was a boy on his father's farm in the Catskills. Probably this is why he keeps so young.

Last spring, with a Boy Scout and his father, a Scout Master, he visited a beavers' colony in a wild wooded chasm in the Dutchess County hills, and was the most interested of that interested three in the work of those beavers-in the trees they had cut down and peeled, and the dam they had built. He brought away some of their chips, and a maple walking-stick-a strong straight stick which they had cut and bevelled at either end in a thoroughly workmen-like way, and now he carries that beavermade cane on all his tramps afield. 
"Sparrowhawk" and his father made a fire and then taught this experienced camper-out one thing he had never heard of-how to make a brigand steak: They selected, peeled, and sharpened a straight maple limb, six or eight feet long, which tapered to the size of a lead pencil, peeling about two feet of the tapering end. On this peeled end the Scout Master strung the pieces of steak, sliced very thin and cut in portions about one and one-half inches square, the folded slices of bacon, and the tender young onions, like beads on a string. Placing a big stone back of the fire on which to rest the tip of the long stick, they slowly turned the stick, thus roasting the meat and onions over the flame. And when all was done to a turn-several of them-in this picturesque rotisserie, and their appetites were whetted to distraction by the savoury smell, the salt added, the string unstrung, the three boys of varying age and size, but each with a brigand's appetite, fell to, and made way with the feast.

Only three days after that and the grown-up boy began to hanker after another brigand steak! "The very name makes me ravenous," he said- "the flavour of the smoke in it - and the smell of it!-I've got to have some more!"

So he built a fire out by his Bark Study at Riverby* and we had our picnic there in far tamer surroundings than that wild solitude of the beavers' haunts. Still his appetite was not appeased, and a few days later, with a party of friends, he climbed to Slabsides, his mountain cabin in the woods a mile or more from home, where, on the rock-girt plain in front of the cabin, we all turned brigands and made merry under the greenwood trees. And often after that, at his midsummer home in the Cats-

\footnotetext{
* His home at West Park, N. Y.
} 
kills, he served brigand steaks under the apple trees, or in the beechwoods, to friends who visited him at Woodchuck Lodge.

Last year in Life, in the Historic Boys Series by E. Foster Lincoln, there appeared a clever caricature of $\mathrm{Mr}$. Burroughs. It represents Johnnie Burroughs as a small barefoot boy in short trousers and checked shirt, but with the white hair and flowing beard we all know. He is holding a rabbit in his hands, butterflies are resting on the crown of his head, a bird is perched on one shoulder, the tail of a grey squirrel is sticking out of one pocket, a red squirrel is running up one leg, and a chipmunk is peeking out of another pocket. A bird has built its nest in his hat, and birds and butterflies and many other wild creatures are hanging around as chummy as you please. It is pretty true to life, this caricature, except that the expression of the boy's face should be happier. He usually has a twinkle in his eye instead of the somewhat worried look the caricaturist has given. But it represents him having a good time out of doors with his wild friends, as he has had throughout his boyhood of more than four-score years.

Probably the most of my young readers learned to know John Burroughs in the Little Nature Series, Birds and Bees, and Squirrels and Other Fur Bearers. I wonder if you remember about the venturesome mouse which he found swimming vigorously in the middle of a mountain lake, its little legs looking like swiftly-revolving wheels; and how the mouse dived as he came near, but came up like a cork, and ran up the oar and shook hands with him. Perhaps you learned to know Lark, his little black and tan, the dog with the gentle heart, who joined him on so many excursions to the woods; and his cat, Nig, who kept 
warm on cold days by sitting on the back of Prince, the horse. Then there was Peggy Mel of such sweet memory, who dwelt in a hive; and Molly Cottontail who lived under his study, faring sumptuously on sweet apples, and thumping her thanks on the floor, or maybe asking for more.

Well, he is just as fond of pets as ever, as you will see if you read his latest book, Field and Study, where he talks about his fussy and quarrelsome wren neighbours, his wood waifs, his tame chipmunks, and his companion, the dog. $\mathrm{He}$ is as fond of a scrap, too, as other boys are, even if it is only a scrap between a wren and a bluebird.

As a rule boys don't hanker after "English" very much, but I imagine it is quite a relief when they come upon "The Apple" in their prescribed work-nothing dry and tasteless about that! Only the worst of that essay is, it makes you so hungry for an apple that you can never read it through without stopping to go down cellar after one-if you are lucky enough to have a cellar, and apples in it. And from that you are pretty sure to read on and on just for the pleasure of it, finding in whatever volume you take up descriptions of things you know and delight in, and discovering others of which you have never dreamed.

To a boy especially keen about birds there is a regular "bonanza" in "The Return of the Birds," "The Tragedies of the Nests," and "Birds' Eggs." In this last chapter "the Bird Man," as some children I knew affectionately named him, teaches you to collect eggs yet leave them in the nest. For the angler there is "Speckled Trout." For the boys who are good campers and trampers there are "Birch Browsings" and "A Bed of Boughs." 
For those who like to hobnob with wild creatures there are "The Snow Walkers," "Hard Fare," and "Winter Neighbours"; and whatever your special bent, you will enjoy paddling with the author down the Pepacton on that summer voyage he took so long ago, mighty sorry you were not there on the spot when he launched his boat in Dry Brook at Arkville (which was not dry at all), and was wishing for a boy just about your age to go along.

Do you wonder why you so enjoy reading those essays - even forget that you are reading? It is because he had such a good time writing them. We usually do well what we like to do. When anyone finds something he especially likes to do, and can do just a little better than anyone else, and in a way all his own, it is probably his particular work in the world. It is often nearer than he dreams.

Among the writings of John Burroughs the things we most enjoy are those which have grown out of the homely experiences of the farm. "Our Rural Divinity" (the cow) was raised on the dairy farm while its author was being "raised" there, too. The Apple essay grew in the orchard at his old home. The "Strawberries" grew there. The Red Fox and the Snow Walkers roamed there-all these and many more grew on the farm and became a part of the boy himself, and behold! when he unpacked his boyhood treasures, there were his books already more than half written! Of course he had to add something of his own, just as the bee has to add a drop of itself to the nectar it gets from the flowers before it can make honey. When that farm-boy was tending sheep, when the wayward creatures led him on many a ramble, and he had to be "dog, fence, and pasture" for them, he was (though he knew it not) doing some "wool-gathering" of another 
kind-he coralled bluebirds, swallows, bobolinks, hermit thrushes and goldfinches in an invisible enclosure, and although they still soared and sang at liberty over the mountain meadows, they will always sing and soar for us from the pages of the one-time boy-shepherd of those breezy hills.

His young correspondents always seem curious as to how he came to write about the birds and wild life, for it is one thing to have a good time out of doors, and quite another to tell about it on paper so that others can have a good time reading it. Some students of rhetoric a few years ago wrote him that they especially liked his Strawberry essay and wished he would tell them how to learn to write as he does. This is what he sent them in reply:

Ah! but I loved the strawberry; I loved the fields where it grew; I loved the birds that sang there, and the flowers that bloomed there; and I loved my mother who sent me forth to gather the berries. I loved all the rural sights and sounds. I felt near them, so that when, in after years, I came to write my essay, I had only to obey the old adage which sums up all the advice which can be given in these matters, "Look into thy heart and write."

The same when I wrote about the apple. I had apples in my blood and bones. I had not ripened them in the haymow and bitten them under the desk and behind my slate so many times in school for nothing. Every apple-tree I ever shinned up and dreamed under of a long summer day, while a boy, helped me to write that paper. The whole life of the farm, and love of home, and of father and mother, and of my brothers and sisters, helped me to write it.

He often says he can never think of his books as works because so much play went into the making of them. He has gone out of doors in a holiday spirit, had a good time, and never lost his relish for his outings. Life has been one long opportunity to learn and enjoy and, through his books, to share his enjoyment with others. He has not 


\section{A GROWN-UP BOY}

had to go away from home to have a good time. He has never lost his appetite for each new day; has kept the same sensitiveness to impressions that he had as a boy; has kept his keenness for adventure; and while most of his enjoyment has come from things and places near home, he has also kept his early curiosity about new things and new lands.

The two books I have oftenest seen in his hands this spring are Darwin's Naturalist's Voyage Round the World, which he is reading for the fourth time, and McMillan's Four Years in the White North. And to-day he is eager to go to Greece and Rome, and to Egypt, and hopes to do so as soon as the world gets steadied down from the great upheaval caused by the World War.

As for the War itself, there was no boy or man in America more interested than he was, and, since he could not fight with sword or gun, he fought valiantly with his pen. Still, fighting is not his forte. His paths have been, like the cowpaths on the home farm, paths of peace.

He still enjoys his farm-boy pastimes with some others that his boyhood never knew. He goes trout fishing every June, every summer hunts birds' nests, climbs trees and picks cherries; he shoots the woodchucks that pilfer in his garden, and hoes among his peas and beans. In the fall he gathers apples from the same trees where he gathered them as a boy. But he also drives his Ford car; and plays by the seashore with his grandson; camps and tramps with him; and sometimes goes on an auto-camping trip with Thomas A. Edison, Henry Ford, H. S. Firestone, and others. Through the winter months, unless he journeys to a warmer clime, though writing in the forenoon, he spends a certain part of each day sawing and splitting 
wood for his study fire. For recreation he walks through the snow-choked woods, or ambles along on the back of his little donkey-Sally in our Alley-a cantankerous beast, so changeable and fickle, and so rebellious at having been transplanted from the Rocky Mountains to the Hudson River Valley, that she finally forced him to part company with her. He even has an ambition to go up in an aeroplane, and declares he will the first good chance he gets. He confidently expects before long to see other friends than the birds flying over his head and alighting near. Alive to all the thrilling things that are happening in the world to-day, he is, in truth, a grown-up boy. 


\section{CHAPTER II}

\section{JOHN'S FOREBEARS}

I PITY the boy who does not remember his grandfather and grandmother. He has missed something that can never quite be made up to him, even by father and mother. The boy is especially rich who remembers two grandfathers and grandmothers. Grandparents had such queer interesting things happen to them, things that they love to tell about and we love to hear, and when they tell what their grandparents did, it is queerer still.

Some persons always skip the parts of a biography that tell about the ancestors, but since boys like to hear about bears, why not a little about forebears?

We are all answers to long sums in addition, and it may be interesting to look back a little ways in the long double column of figures that, when added up, gives the answer, John Burroughs.

One of the early figures in the ancestral column was an English navigator of the sixteenth century, Stephen Burroughs, who made two voyages to discover a northeast passage around the eastern continent (in 1553 and 1558), doubling Cape North on the last voyage, touching at Nova Zembla, and reaching the highest north latitude that had then been reached. He published an account of his discoveries and observations on returning to England. $\mathrm{He}$ was the first to discover the declination of the magnetic needle. 
The men from whom John Burroughs descended came to America from the West Indies in 1690, settling chiefly in Connecticut and Massachusetts. One of their descendants was a Stephen Burroughs, born in Connecticut in 1729, shipbuilder, surveyor, astronomer, and mathematician. He was the inventor of the system of Federal money adopted by Congress in 1790. His brother, Ephraim Burroughs, born in 1740, was the great-grandfather of John Burroughs. But before coming nearer let us glance at two more remote ancestors: There was still another Stephen Burroughs, whose career, if less praiseworthy than that of the English navigator, is picturesquely interesting. He was an adventurer. Born in New Hampshire in 1765, the son of a Congregational clergyman, he certainly made things hum from very tender years. Running away from home at the age of fourteen and enlisting in the army, he was a Revolutionary soldier for awhile, but deserted; entered Dartmouth College, but on getting into a serious fracas there, ran away, becoming in turn, ship's physician, preacher, and schoolmaster.

While serving as preacher in Pelham, Massachusetts, he was much liked and respected, although he confessed later that he palmed off as his own sermons of his father's. (One wonders how he managed to keep them by him in all his varying fortunes.) While carrying on this life as a preacher, he was discovered to belong to a gang of men engaged in making counterfeit money.

Later in life he became a Roman Catholic, and, living at Three Rivers, Canada, was tutor to wealthy Canadian youths. At his death, in 1840, he had a fine library, and had earned the reputation of being an excellent teacher. 
It is said his pupils were enthusiastically attached to him. And why not? With his experiences, he must have had many a racy tale to hold their interest.

To offset this scape-grace Stephen, we find another ancestral figure of most exemplary life and character-the reverend George Burroughs, a graduate of Harvard College in 1670; a victim of the Salem witchcraft, his offence being that he had a mind of his own. Openly asserting that he did not believe in witchcraft, he incurred the enmity of Parris, a rival clergyman, and of the reverend Cotton Mather, who had preached and written about it. For his independence he was declared to be bewitched himself and sentenced to be hanged.

The day before the execution, Margaret Jacobs, a young woman who had testified against the condemned man, sought an audience with him and, confessing her guilt, begged forgiveness. He not only forgave her, but prayed with her. Many of the people, convinced of his innocence, implored Cotton Mather to spare his life, but that inhuman divine, reminding them that the Devil was often transformed into a very angel of light, declared this apparently saintly man to be the vilest of the vile.

The prosecutors had claimed that the witches, or wizards (for I suppose that is the masculine of witches) could not repeat the Lord's Prayer, but even though the accused did repeat it, composedly and reverently, while standing on the scaffold, his persecutors would not relent. Friends sobbed and moaned and entreated, but Cotton Mather, dashing among them on horseback, mocked the victim, and, uttering maledictions on those who would show mercy, drove the hangman to his work.

At about the close of the Revolutionary War, Ephraim 
Burroughs, the great-grandfather of John Burroughs, came into New York State from Connecticut. He was a farmer, and lived near Stamford in the Catskills. Now, as the Bible records would say, Ephraim begat Eden, and Eden begat Chauncey, and Chauncey begat John, and so we reach the "answer" from one side of the ancestral column.

Eden Burroughs and Rachael Avery, John's paternal grandparents, moved into Delaware County from Stamford, in 1795 , slowly and laboriously, by cutting their way through the woods, and hauling all that they owned in the world on a sled drawn by a yoke of oxen.

They settled down amid the Delaware County hills at the foot of Old Clump,* a high wooded mountain with an altitude of 3500 feet, near the village of Roxbury (or Beaver Dam as it was originally called). There they made themselves a rude shelter until they could build a more substantial one. The first shelter consisted of four crotched-poles driven in the ground with horizontal plates laid across, and with two taller crotched-poles to support the ridge-pole. Over this was spread a covering of elm bark. Elm bark was also used for the floor. The pioneer then felled a huge maple for a back-log, and built his fire in front of this shelter, and there his wife cooked their food in a kettle suspended over the fire. Their furniture was home-made. The table was of rough slabs into which holes were bored and legs fitted, and their chairs, bedsteads and other furniture were of the rudest kind.

In the little clearing which they made, John's grandparents soon put up a log house, building it with their own hands, helped by the neighbours. It was the custom

\footnotetext{
* Re-named the Burroughs Mountain, in 1915, by the citizens of Roxbury.
} 
when a newcomer came into the county for the neighbours to make a "bee"* and vie with one another in their efforts to help him build his house. The roof of this house was of black-ash bark, and the rough-hewn floor of white-ash logs. They also made a huge stone fireplace with mortar of red clay. Grandmother Burroughs said it was the happiest day of her life when the little house was done and they moved in it. There in that little hut in the woods they lived and toiled, clearing the land of the trees and rocks, raising their crops and their children, and finding life sweet, even if they did live close to the bone. Grandmother Burroughs used to help in the fields and at sugarmaking in the sap-bush, and later on, rode long distances to mill through the woods, herself, a baby, and the mealbags carried by the faithful horse.

Great grandmother Avery came to live with these grandparents after a little, a sensitive woman of petulant disposition. One day when something had gone wrong, she went off and hid in the bushes and sulked, and they had a long hunt for her-" "a family trait," her greatgrandson admits-"I'm a little that way, I guess."

In this humble log house the father of John Burroughs was born, and over a hill and down in another valley, in a little, weather-worn, unpainted farm-house, John Burroughs himself was born one early April day in 1837. That house is no longer standing, it having been moved to the orchard (and later torn down) when, in 1850, the present house, which Mr. Burroughs calls the Old Home, was built on the old site. His father bought his farm of three hundred and fifty acres of a neighbour, Widow

* A gathering of neighbours for work or amusement, e.g., husking bees, moving bees. 
Bartram, who had bought it of Desbrosses, the man for whom Desbrosses Street in New York is named.

At the time that Eden Burroughs came into Delaware County, there were probably not more than one hundred persons in the whole county. It was largely a wilderness of pine and hemlock. Shortly before this the Indians along the Delaware had had their settlements, trapping for beaver, otters, and martens, but had then gone along the Susquehanna, and still farther west, in search of better hunting-grounds.

Some years after Eden Burroughs came to Delaware County, the stocks and a whipping-post were erected at Dimmick's Corners, ten miles distant. The first person to be punished in the stocks was a carpenter in 1797 who had been caught stealing grist. He was put in the stocks, barefooted, for a day and a night, and the small boys were allowed to tickle his feet, and mock him, after which he was given fifty lashes at the whipping-post, and sent about his business.

Grandfather Burroughs was a spare man, a seriousminded, hard-working farmer, a lover of peace and solitude. Grandmother Burroughs was of Celtic origin; she had a sandy complexion; was warm-hearted, and cheery of disposition.

John has heard them tell how his grandfather every fall used to ride forty miles to get a bag of apples, and seedlings at that, bringing it home on horseback. (Perhaps they were the ancestors of the fruit from which that Apple essay grew.) Once on leaving home at three in the morning to make the long journey, he and his horse were badly frightened by the screaming of a panther as they went through a narrow pass in the mountains. 
Although John remembers but little about these grandparents who died when he was very young, he well remembers his maternal grandparents, Edmund Kelly and Lovina Liscom, the Granther and Granny of his boyhood years.

Granther Kelly was a short man with a big head and distinctly Irish features. He was born in 1767. His long blue army coat with brass buttons and his red-top boots were the admiration of John's boyhood. He was a soldier under Washington in the War of 1776. Going into the war in the last two years as a lad of fourteen, he served at first in some humbler capacity, later carrying a musket as a regular soldier. He saw Lafayette. He was with the army at Valley Forge. What tales he used to tell of that terrible winter the army spent there! "Zuckers! but it was monstrous cold," he used to say. (Granther never swore, but he put a good deal of vim into that word "Zuckers!" "Zounds!" was another of his favourite words.)

Granther was keen for adventure, and liked the life of the soldier far better than the humdrum one of farmer and provider for a large family. When the War of 1812 broke out, and one of his sons was drafted, he went in his stead. He was gone a year or two, and though not actually in battle, was in some lively skirmishing. John remembers his tale of bivouacking one night in a hollow in the ground made by an overturned tree-he slept soundly through a rain-storm, and on awaking found his cradle half-full of water.

When Granther was given his discharge from the army, he "footed it" from New York, going through the river towns on the east bank of the Hudson. He tried house 
after house, asking for a night's lodging, and was refused. They were evidently all Tories and so refused hospitality to a soldier in Yankee uniform. Wearied, he finally crawled in an out-building near a house that looked no more promising than the others, and there spent the night. In the morning, on leaving, feeling disgruntled, he gave them a parting shot, shooting through the peak of the house. This brought out the man who, on seeing a soldier with his musket, asked what the shot meant. Granther explained that he had slept in the shed and thought he would give them a salute for his night's lodging; then, seeing the mystified expression of the farmer, who seemed friendly in spite of this strange conduct, he rehearsed, somewhat abashed, his hard luck of the preceding night.

"Too bad, too bad! my friend-if you had only come to the door, you should have had the best in the house."

His soldier grandfather was a great hero in John's eyes, and the lad thought when he grew up he would be a soldier, too.

Brave as Granther was, he was afraid of spooks and hobgoblins, and would tell his grandsons tales about them that made their hair fairly stand on end. He believed his own stories, too, shuddering with the frightened lads as they huddled around him and listened, trembling as they listened.

An expert trout-fisherman, he and Johnny were real pals. Many's the time they went over in the West Settlement or down in the Hemlocks fishing, and when past eighty he would steal along the streams and deftly "snake" out the trout.

His only reading was the Bible, but he spent a good deal of time poring over that. In fact, he went from Book to 
Stream, and from Stream to Book with great regularity, but was not a bit fond of work. Granny, a big, thrifty woman, who had her hands full with ten children to feed and clothe, often took him to task for his shiftlessness. But however poor a provider he was, in trout season, as a rule, he was ready to supply the fish, though it is doubtful if there was always fat in the house to fry them in. John says Granny was big enough to take Granther across her knee and spank him, though he never saw her do it. He confesses that he gets his "dreamy, shirking ways" from Granther Kelly, as well as his love of the woods and streams and all outdoors.

Moving over to Roxbury from Red Kill in their last years, Granther and Granny lived in a little house on the east end of the home farm. John was there one morning when they had a coloured man who had stayed over night. After breakfast the man prayed-“oh! how lustily he prayed!"-and shortly after went quietly away. He was probably a fugitive slave. It was a few years after the Fugitive Slave Law had been enacted.

John remembers that once when walking along the road with Granther in those days, and carrying the old musket, as they stopped on the Giant Stairs to rest, Granther suggested, "Now, Johnny, let me see how well you can shoot"; but the thrifty lad, resisting the temptation to show off, replied, "I don't want to waste my shot," and Granther, easy-going and improvident as he was, did not press the matter, though he must have wondered who the boy "took after" to be so saving.

He was fond of game, and toward the very last of his life, the boys got him a good fat 'coon, which he ate with relish. 
A brother of Granther's, who was something of a hermit, or, as he used to say, "a monstrous queer man," lived by himself in a hut in the woods - the original Slabsides, perhaps. They would hear him talking to himself as they neared the hut; it sounded as if there were half a dozen there. He had a habit when walking along the road of stopping, standing still, and gazing all around. In telling of this Mr. Burroughs says he has the trait himself, but his gaze is surely not as unseeing and aimless as his hermit ancestor's probably was.

John Burroughs, as we have seen, comes from a long line of farmer folk. Although his father had been a school teacher in youth, he knew nothing of higher education. He was first, last and always a farmer, and a good one, too; a sturdy man, with red hair and a ruddy, freckled face; unselfconscious and unsophisticated. His voice was harsh and strident. Emotional but tender-hearted, he would refuse his boys the days off for which they coaxed, with a great show of severity, but usually ended by granting them; his bark was worse than his bite. He made many a threat to take a gad to the boys, but few were the fulfillments of the same. John remembers getting only one flogging. It was when he had let some cows get into a clover-meadow after having been warned to keep them out.

Farmer Burroughs worked hard himself and believed in boys doing their share, too, and a boy's work on a dairy. farm was no "cinch," as we shall see.

Amy Kelly, John's mother, was a plain, unlettered woman, who, though she never read one of her son's books, had an inkling, even while he was a boy, that he was going to do something big some day. Treating him with marked 
tenderness, she took his part when his odd ways annoyed his father, often inveigling the latter into granting some of John's desires, though he usually declared they were all nonsense while granting them. She had a serious, brooding cast of mind, and a yearning heart.

There were ten children in the Burroughs family. Imagine the way their mother had to work to keep them all clothed and mended and darned and fed, and yet attend to her numerous duties as a farmer's wife on a dairy farm! Still she found time to go a-berrying, roaming over the hill meadows with little John, the best berry-picker of all her children. In fact, her happiest times were when she was in the fields after berries; it was almost the only recreation in her life of constant toil. 

CHILDHOOD 



\section{CHAPTER III}

\section{EARLY MEMORIES OF FARM AND HEARTHSTONE}

We have no photograph of the boy John Burroughs, but his memories of babyhood and childhood will help us to picture to ourselves the kind of a child he was. Strangely enough, for one who was later, for good reasons, to be nicknamed "John o' Birds," his earliest recollection is about a great bird: One summer when he was perhaps three years old, while playing along the road by the big hill some distance beyond the house, he saw a great hawk sailing round and round in big circles, high above him. Like many another hero, ours began by being afraid. Just what he was afraid of he doesn't know, but the sight of that great bird filled him with fear, and, creeping behind a stone wall, he crouched there a long time till the hawk either soared up and up into the blue, or perhaps dropped from his trackless voyage in the sky and pounced upon a meadow-mouse which thought itself hidden in the grass. At length, on peering out and seeing no swooping hawk, Johnnie went marching home.

\section{THE STOLEN CAP}

Back of the house where he was born is a long broad hill, a lower slope of Old Clump-the mountain in the lap of which the homestead rests. This hill is steep and smooth and fertile. Many an April he has seen it grow 
ruddy under the plough, its soil of decomposed old red sandstone showing red like a robin's breast in the spring.

In front of the house a long flight of stone steps of rude masonry, built of the native stone, led from the doorway to the road below. On these steps the child of three experienced his first grief: One day as he was playing there the "hired girl," coming out to sweep the door-stones, mischievously snatched his little cap from his head and threw it down the long flight of steps. This seemed a great indignity to the child. He remembers just how disconsolately he stood there, that warm spring day, crying over his stolen cap; how abused he felt; how wistfully he looked up to where his father, with bag slung across his breast, was striding across the side-hill, scattering seedgrain. As he wept he longed for him to come down and punish the girl for throwing his cap down the steps. The injured feeling, the helpless anger, and the desire for justice to be visited upon the culprit which that child then experienced are vividly recalled by the man to-day.

\section{THE OLD KITCHEN}

The old kitchen was a plain homely room in which centre some of the tenderest recollections of John Burroughs.

Sealed overhead and on the sides, it was painted a dull red. It was a gloomy room by night with only the fire-light and one flickering candle. There was no carpet or rug on the ash floor. Two windows looked toward the road and one toward the "sapbush,"* and opening off from it were many doors - the outside door, one to the buttery, one to Mother's bedroom, with the back-bedroom on beyond, the door leading upstairs, with a step

* A grove of sugar maple trees. 
from the stairs coming out into the room, and one to the hallway, from which one went down cellar, or on into the "other room," as the parlour was always called.

A tall, blue-grey cupboard stood in one corner with the dishes above-they were the mulberry pattern-and victuals below.

The walls were nearly bare. An old Terry clock stood on the shelf, with its quaint scene on the door of a picturesquely clad swain blowing a hornpipe, and a lassie in yellow gown and black slippers dancing. Under the shelf was the Farmer's Almanac. A home-spun roller towel of true democracy hung near the buttery, and a boot-jack by the wood-box.

On the mantelpiece Farmer Burroughs kept his pipes and tobacco, and there were the iron candlesticks, the brass snuffers, and the sulphur matches near by; but when 'John's father wanted to light his pipe or a candle, he took a live coal from the fire with the tongs, and blew on it, thus making the matches go farther.

Besides the cupboard, there was the cherry drop-leaf dining-table, a stand with the mending basket, the little low blue cradle, a Boston rocker, some wooden-bottom chairs, a few splint-bottom chairs, and the washbench.

The picturesque part of the room, of course, was the deep stone fireplace in which great logs were burned, and the brick oven close by with its heavy, charred door of pine. This oven was deep enough to accommodate twelve loaves and more.

Overhead, at certain seasons, on poles suspended from the ceiling, hung strings of dried apples and rings of pumpkins. On the table, in the winter evenings, sat a pan of apples which one of the boys would bring up from 
the cellar after supper. There were not many left in it by bed-time.

A humble, homely room it was, but there the boy John Burroughs lounged and dreamed by the fire, and read and pondered in the candle-light. "How far that little candle throws its beams!"

\section{THE BLACK HOLE}

By day the doorway leading to Mother's bedroom was just a doorway, nothing more, but by night it was another story. Granther Kelly's tales of hobgoblins caused strange things to happen after dark. One night when John's parents had been to Red Kill, eight miles over the mountain, to visit Uncle Martin, and were late in returning, and that docrway was as dark as Podunk, as the lad's father used to say, the goblins certainly seemed hovering just beyond that opening. Huddled in the furthest corner of the dimly-lighted kitchen sat little John with his brothers and sisters, all of them watching uneasily that blackness of darkness.

What fearsome creatures lurk there? How long will they stay hidden? What hideous shapes will they take when they loom up in that doorway? Will Mother never come? How the wind howls! How the shutters rattle! And that black doorway on which their gaze is riveted!

But, Joy! the sound of wheels!

"They've come! They've come!"

Father's voice is heard shouting for the lantern. The huddled group scatters. Glad cries and skurrying feet greet Mother's return to her frightened bairns. As she comes hurrying in at the door, Fear flies out at the window, and in the bustle and talk the lurking spectres vanish, too. 


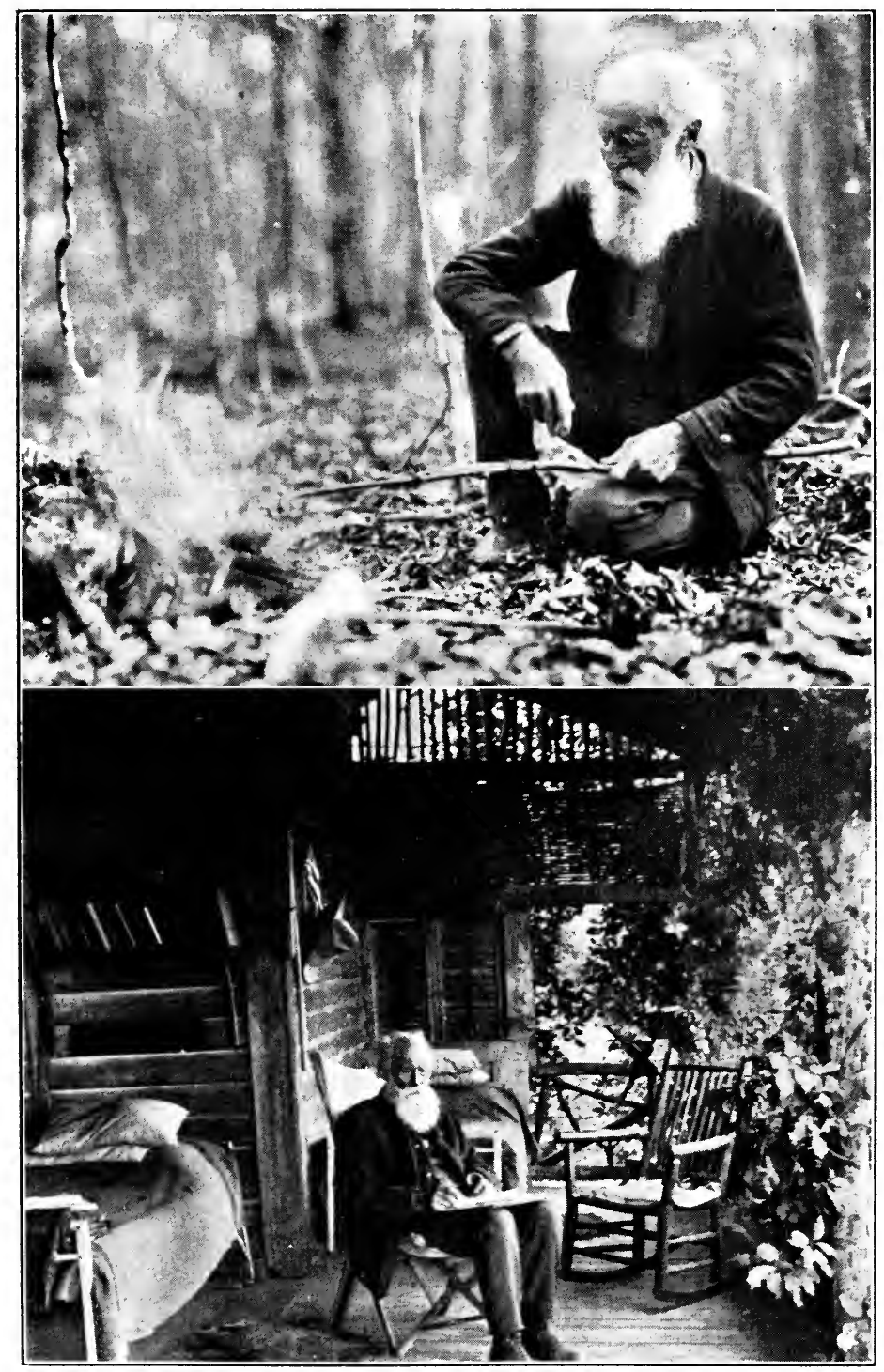

A brigand steak in the beechwoods

Photo by George E. Stone

On the porch at Woodchuck Lodge

Photo by Dr. G. Clyde Fisher 


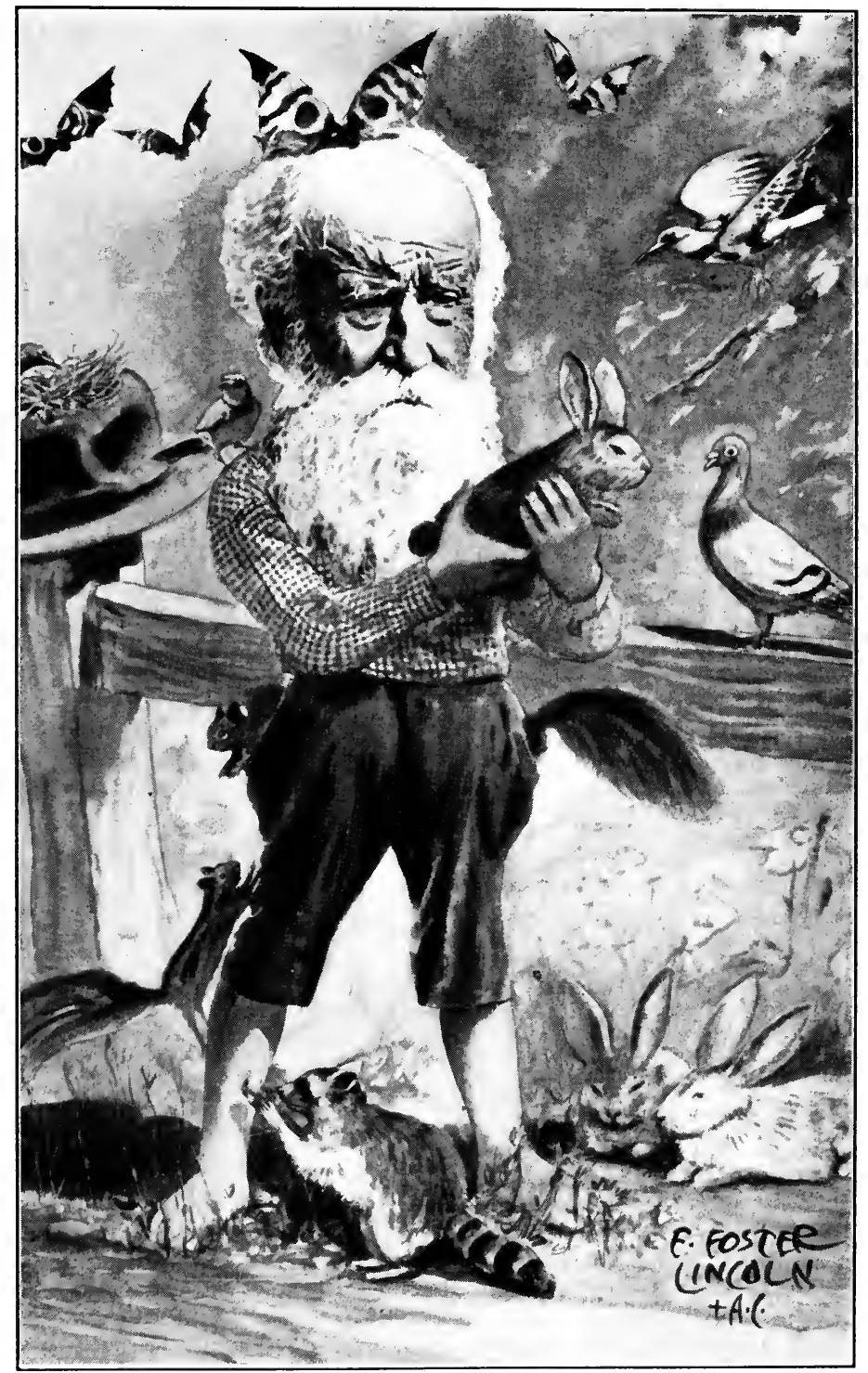

(c) Life Pub. Co.

Johnnie Burroughs and his friends 
The little bedroom is soon cheery with candle-light. The trundle-bed is drawn out from under the big bed, and John and Eden, tucked in by Mother's comforting hands, forget all about the great black hole as they drowsily slip away to the Land of Nod.

\section{ROUGH AND TUMBLE (As told by John)}

"One day when Sister Jane and I-we must have been very young-were playing in the unused chamber overhead, we found an old keg and proceeded to ride about on it, leaning on with our chests and pushing with our feet.

"When we came to the head of the stairs, the long flight did not give us pause. We rolled on down, struck the door at the foot, and burst into the kitchen like a catapult, and there we sprawled! It nearly scared Mother to death. I was knocked senseless and only remember waking up in the back-bedroom with the smell of camphor pervading the room. How Jane fared, I don't remember."

\section{A TORCHLIGHT PROCESSION}

Martin Van Buren was President of the United States when John was born, and John was three and a half years old when the campaign was on for the election of Harrison and Tyler. He remembers that well. Of course he did not know what it all meant, nor why they shouted "Tippecanoe and Tyler, too!" and "Van, Van, is a used-up man!" It was many years later before he understood the significance of those rallying cries of the Whigs, or learned of the old hero's defeat of Tecumseh at Tippecanoe Creek so many years previous; but he clearly recalls the men going by with torches in a lumber wagon, with a 'coon 
hoisted high on the end of a pole. He has no recollection of the log cabin with its latch-string hanging out, or of the hard cider that also figured so conspicuously in the spectacular processions of the Harrison-Tyler campaign.

\section{THE RED BIRD}

One day in May when Johnnie, a child of four, was playing near the hearthstone, the housemaid came in with a pail of chips on which there lay a bright red bird found in the chip-yard. When the child spied the bright bird with its coal black wings (a scarlet tanager), he jumped up and ran eagerly to the maid; but the next instant discovered that the bird was limp and lifeless. From the brilliant little creature he got his first realization of death.

Tears filled his eyes as he turned away to his corner on the hearth; a queer ache came in his throat-love and sympathy for the little bird were born together in his heart; but curiosity was born also, and he soon turned back, and taking the dead bird in his hand, stroked its scarlet plumage.

\section{MINDING THE BABY}

"Come, John, and mind the baby!" his mother used to call, and John, a boy of five or six, would come and rock the little low pine cradle where lay baby Abigail, while his mother went to her spinning in the chamber above. Sitting on the cradle at its foot and rocking back and forth, back and forth, he listened to the monotonous humming of the spinning-wheel till, falling asleep himself, he dropped over by the side of the baby, where his mother would come and find them both. 


\section{THE CRICKETS ON THE HEARTH}

He liked to lie on the hearth in front of the big fire of an evening and watch the light-coloured, long-horned crickets; and the crickets liked the warm cozy corner as well as John did. He had a grudge against the greedy creatures, for Granther had told him they ate holes in his stockings.

Night after night he lay there and watched his mother patiently darning, her tallow dip hung on the back of a chair. He pitied her; the pile of stockings always stayed the same size. He wondered just which hungry crickets made those big holes in the heels which took her so long to mend; and not knowing, caught and killed every one he could. They were lively things and jumped a long ways with those long legs, but John was lively too, and grew very spry, pouncing on them as they came up out of the cracks in the floor.

\section{RUINED CASTLES}

Hiram, Wilson, and Curtis, the elder brothers, often sat around the hearth in the long winter evenings shelling corn into a bushel basket. A long frying-pan handle thrust through the ears of the basket was held in place at either end by chairs on which the shellers sat as they scraped the yellow ears against the iron. John and Eden hovered near, delighting in the rattle of the kernels and the golden shower falling into the basket. When there were enough empty cobs they seized upon them and built houses, bridges, and castles that towered uncertainly.

"Here! pick up them kernels!" the elder boys would shout, and as John and Eden scrambled about in quest of the scattered corn, the shellers mischievously toppled over 
their carefully-built structures. Angry, but undismayed, the little builders set to work to reconstruct their ruined castles.

\section{THE FIRST JOURNEY}

The child loved best to play about the hearth and the door-stones, but there came a day, when he was four or five years old, when a new desire burned within, and he made his first journey out into the world.

Out past the watering-trough and the barn he ran, up the hill, past the "Pennyroyal Rock," past the turn in the road, and then started on down the Deacon road as fast as his sturdy little legs could carry him, all the ardor of the explorer urging him on; but on suddenly looking back and seeing how far he was from home, he was seized by a panic and ran back as fast as he could.

"I have seen a young robin do the very same thing on its first journey from the nest," said the man in recalling this episode.

\section{THE FIRST DAY AT SCHOOL}

Before John was five years old he was sent to school a mile and more away, to the old stone school-house down on the Hardscrabble road.

"He may as well be learning his $a-b a b s$ in school as getting underfoot at home," his mother said. So she dressed him in his first suit; it was of striped blue and white cotton; he had watched her make it, and was especially proud of the little caps on the shoulders that flopped as he ran.

How excited he was as he started out over the hills with his sister, Olly Ann!

"Who lives here?" "And here?" he asked as they passed the few houses along the way. 
The walls of the schoolroom were of rough, unhewn stone, whitewashed. The floor was built on an incline, so that the back seats were higher than those in front. The smaller fry sat around the wall on a bench made of a broad hemlock slab with widely slanting legs, the seat so much too high that John's feet dangled uncomfortably.

A few days later, when some of the newness of school had worn off, the little fellow fell asleep and, tumbling off the bench backward, cut his head on the rough stone wall.

He fainted and was carried to a neighbour's, where camphor was rubbed on his temples, and the ugly cut dressed with liniment. Even now, when past eighty-three, the smell of camphor recalls that darkened room, the high bed on which he found himself on coming to, and his bandaged head.

He learned his letters from the old Cobb spelling-book, and had a hard time before he could tell $b$ from $d$ and $c$ from $e$; but he conquered these difficulties before Hen Meeker, a much bigger boy, did, and one day when Hen stuck on $e$, the teacher shamed him by saying:

"Why, even little Johnnie Burroughs can tell what letter that is. Come here, Johnnie!- what is that?" And sliding down from the high bench, Johnnie proudly marched to the teacher's desk and announced that it was $e$ !

There in a corner of the school-yard he experienced his first betrayal: Something having happened to cause him deep chagrin, he had gone there to be by himself and weep. An older boy, the meanest boy in school-and he became the meanest man in the town-found him snivelling and sulking under a tree, and promised him a fine long slate-pencil if he would tell him what he was cry- 
ing about. John hesitated, but that pencil did the business. As soon as he confessed, however, the scoundrel ran away with the pencil, shouting the secret to the other boys!

Some months later John's sense of justice was satisfied when his brother Wilson had a fight with that boy and "licked" him. The fight had started over some other mean trick. Wilson threw the rascal down and, sitting on his back, grabbed him by the hair and jammed his face down on the crusty snow till it bled. The other boys, egging him on, cried, "Give it to him, Wilson! Give it to him!"

"Wilson, I'll take the law"- the victim tried to protest, and down would go his face again in the snow.

Little John, remembering his own grievance, and the older boys, with many an old score charged to the culprit, looked on, gloating to see the bully get what was coming to him.

\section{THE FIRST SWEETHEART (As told by John)}

"I can see her now, as she came running down the hill from the school-house, the cape of her little pink sunbonnet fluttering in the breeze," said Mr. Burroughs as he pointed out the course she took down the road to her home.

"I must have been between five and six years old. I had gone over to Neighbour Bartram's in the West Settlement with Father on a stone-boat* drawn by the oxen. Father probably went there to help him draw stones for a new piece of wall-they used to exchange work in that way.

"I can hear her father's voice as he sent it over the hills

* A drag or sled without runners, used for hauling stone. 
to the school-house- he had a prodigious voice- 'Eleanor, come home!' And soon she came flying down the road to play with me.

"We played by the barn on a little mound of hay. I remember we made a nest there-I can see her now as she took a wisp of hay and pinched it together, making believe it was an egg and that she was a hen-I can see the sharp angles of the shining hay as she tried to shape it like an egg before she hovered it in the nest."

The time to leave little Eleanor came all too soon. John felt very forlorn as he and his father followed the oxen homeward, and the little pink sunbonnet down there in the valley grew smaller and smaller, and finally was entirely lost to view.

\section{THE STRANGE BIRD IN THE DEACON WOODS}

One Sunday in May when John was seven or eight years old, as he and his brothers were in the Deacon woods after wintergreens, and he lay on the ground idly gazing into the branches above him, he spied a small bluish bird with a white spot on each wing, flitting amid the branches.

Excited, he questioned his brothers as to what it was. They neither knew nor cared, but it was a great event to him. Right here in these woods come strange birds from distant lands! It fired his imagination: "I must be on the lookout for them-Where can I find out what they are?-I wonder if this one will ever come again"thoughts like these flashed through the mind of the curious boy as he watched the little visitant hopping in the beech trees before it flew away.

It was not till near twenty years after that he learned its name-the black-throated blue warbler. There were 
no bird books to help boys in those days. The one who started the making of many books of this kind was then just getting his first lessons from the Book of Nature; he was, in fact, at this stage, only looking at the illustrations.

A few weeks later, again the Burroughs boys, with a neighbour, were roaming the same woods when a brown bird with a speckled breast flew from a bush to the ground in front of them.

"What is it?" asks John, the ever-curious.

"A brown thrasher," replies the older boy, and John knows no better then. But years later, remembering the ways and looks of that bird, he decided that it was a hermit thrush. He had it "for keeps" in eye and memory long before he knew its name.

\section{THE BOY AND THE ELFIN PIPER}

In the bright March days of the spring when our lad was eight years old he grew very curious as to what it was making those shrill cheery sounds in the swampy places. What bird is it wetting its whistle down in the bog, he wondered. He asked everybody around, but as no one could tell him, decided to find out for himself.

One evening while it was yet light, going to the rushes alone and creeping in among them, he scrooched down and stayed there a long time, as still as a mouse.

Soon a tiny, yellowish-brown, mottled frog, less than an inch long, with pointed nose and bulging eyes, climbed the bulrush, hand over hand, as a sailor climbs a mast.

John held his breath. He was afraid the little creature would hear his heart thumping and jump out of sight. But lo! the bag-pipe that the midget carries under his chin swelled up as though it would burst and Phee, phee, 


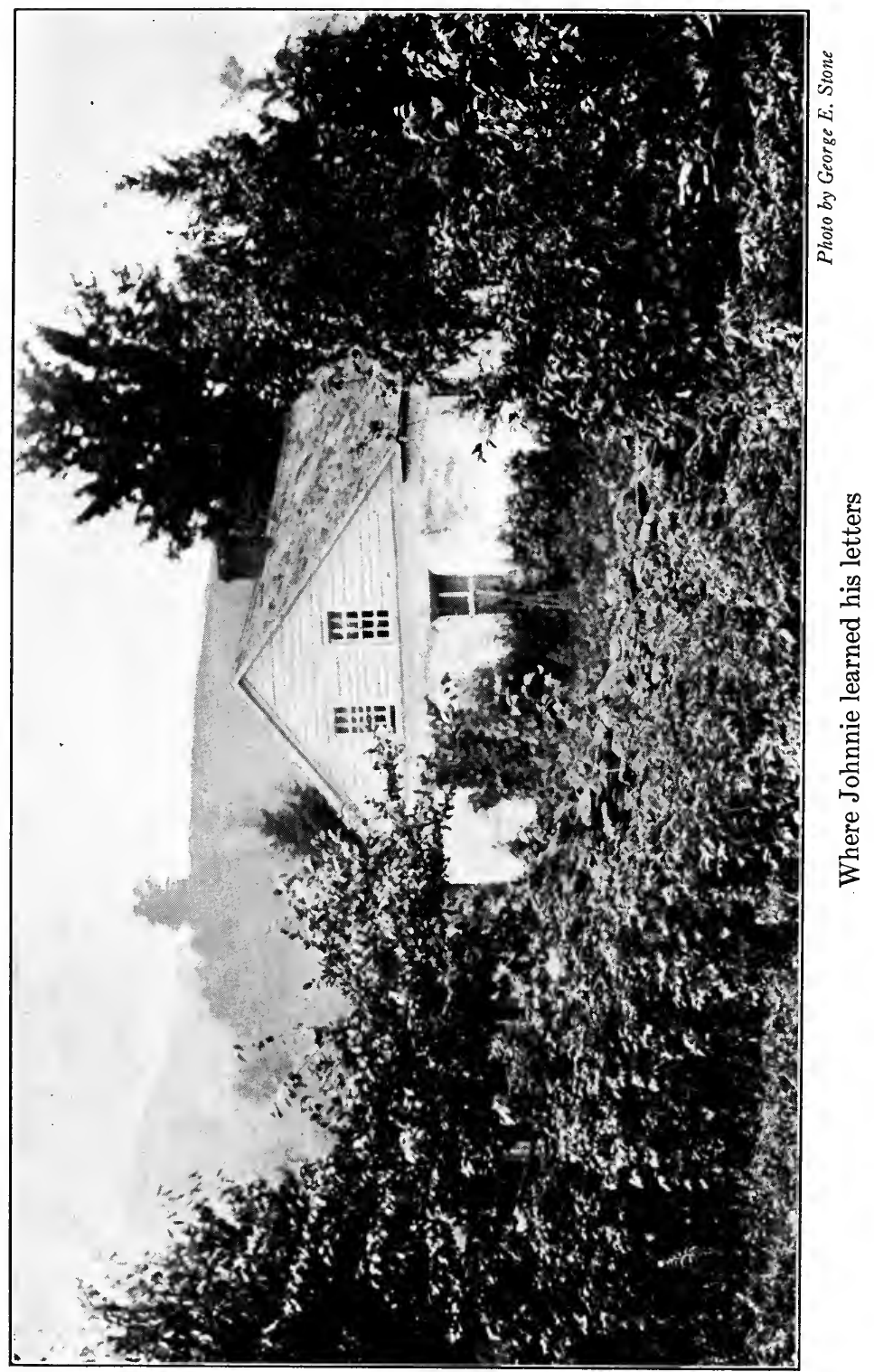




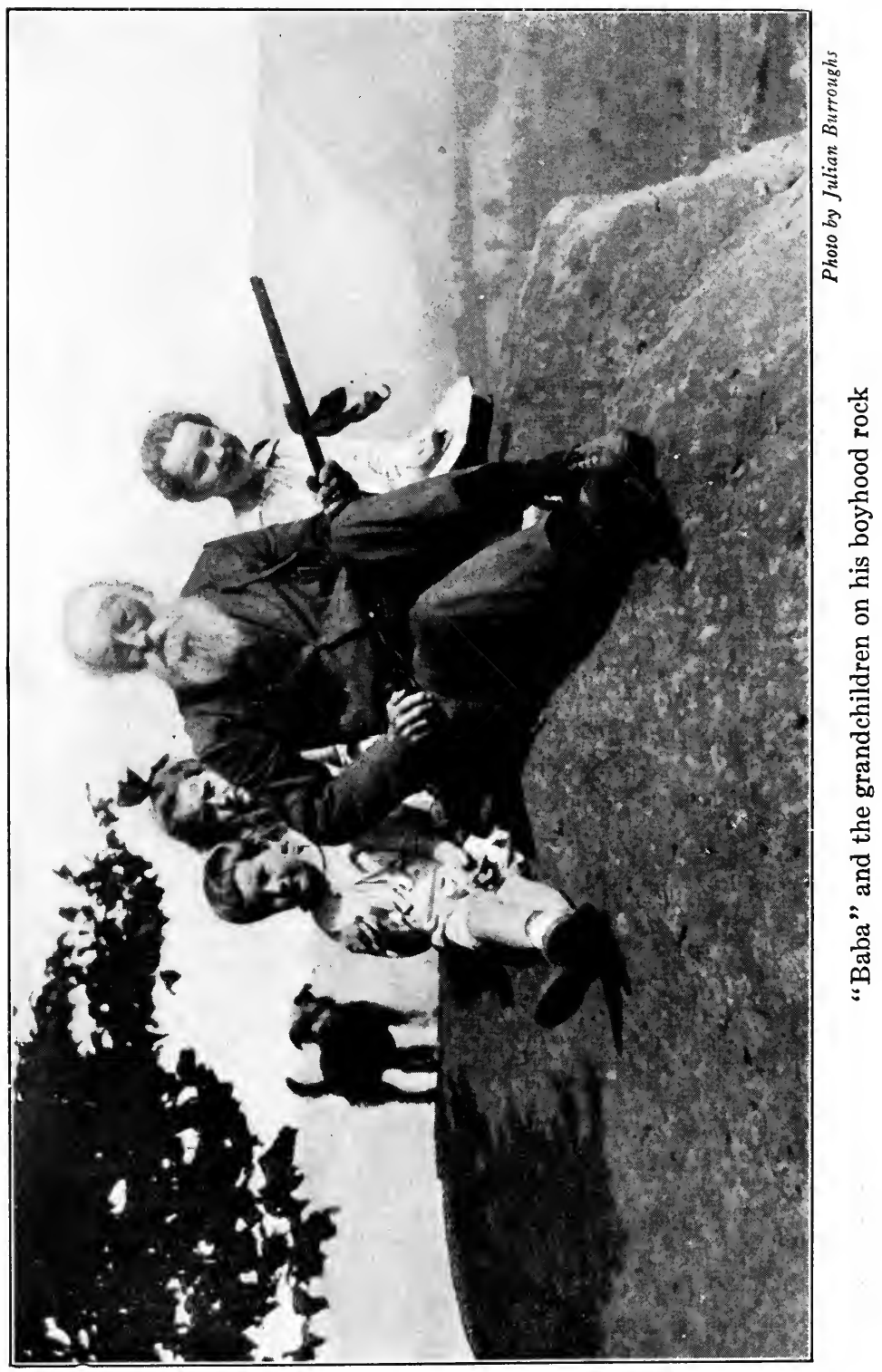


phee! shrilly called the elfin piper, just a few inches from the ears of the patient lad.

Cautiously he stretched forth his hand and grasped the elf. After a long time, when the tiny creature had become accustomed to his new perch, he inflated his throat and piped from the boy's hand!

It was the spring peeper* (Hyla crucifier) whose shrill pipings we hear in the marshes in early spring.

\section{THE LITTLE SAWMILL}

In John's boyhood it was an unheard of thing to have pleasures planned for boys and girls. Life was a serious matter for the grown-ups, and they tried, though in vain, to make the youngsters regard it in the same light. Play was not considered a preparation for life's activities as it happily is to-day. Toys were rare articles. Boys had to make their playthings or go without. Holidays were as scarce as hen's teeth, or as white blackbirds, and it sometimes keeps one guessing to see where the boys, with all their chores to do, got in any fun. But they managed it somehow, gleaning it here and there, from day to day.

By the roadside, in a little stream that overflowed from the watering-trough, Hiram helped him build a small sawmill when John was about ten years old. He made the little dam himself, working at it in the long summer forenoons as, barefooted, he splashed about in the mud, lugging the pieces of sod and the stones, and fitting them snugly in place.

The flume consisted of an old pump-log with a tin horn at the end. The slant was at an angle of about thirty degrees. The water came out at the end of the horn with

\footnotetext{
* Formerly called Pickering's Frog (Hyla pickeringi).
} 


\section{8}

JOHN BURROUGHS-BOY AND MAN

a good deal of force and struck the buckets of the wheel, causing the wheel to revolve pretty swiftly. It was an overshot wheel with tin buckets. On the shaft of the wheel they fixed a little crank with a frame and a small saw, the saw having been cut out of a piece of tin. The gate was like the gate of a regular sawmill, and this held the saw which played up and down in a proper groove of the upright frame. There was a little carriage which they had to move by hand, on which the log rode; and for a sawlog he used huge cucumbers, sawing them up into the desired lengths.

One day a farmer and his wife driving along paused and watched him working at his little mill.

"Hello, there!" the farmer called out. "What's the price of cucumber logs to-day?" And as they drove on the goodwife exclaimed, "I declare, that boy's as odd as Dick's hat-band!"

As he grew older he did not relish being called odd. "An odd 'un" was a phrase often applied to him. It always struck him as something not quite nice, he did not know exactly why. When strangers came to the house, and singling him out, asked, "Whose boy is that?-he ain't your boy," he would hang his head in shame.

Uncle William and Aunt Nora who came from Rochester evidently liked the "odd" boy, and tried to get Farmer Burroughs to let them have him to bring up. The lad thought he wanted to go with them, but his parents couldn't make up their minds to give up their "odd 'un."

\section{THE OLD DOCTOR}

One summer day when John was digging potatoes out beyond the orchard, he heard Gould Bouton, who had been 
hunting with Elihu Meeker up on Old Clump, shout down that Elihu had fallen from a ledge and was badly hurt. Farmer Burroughs and Hiram went up there with the sled and the oxen and brought him down to the house, and Curtis hurried down to the "Hollow" for old Doctor Newkirk.

The man's groans were terrible to hear, and to John and Eden, looking on and watching for the doctor, it seemed an eternity. They feared Elihu would die before the doctor could get there.

Finally they spy him as he appears over the top of the hill-a tall man, urging on his horse, his big leather saddlebags bobbing up and down behind on the horse's back.

"The doctor's coming!" the boys shout, running to the house, and they feel a great load lifted-Elihu will be saved now, the doctor has come! What utter confidence they feel in his mere presence!

There were times, however, when the doctor's coming was not so welcome to the boys, the times when there were teeth to be pulled. That was a fearful ordeal: With his turnkey wound with his red bandanna to keep it from slipping, the old doctor would clamp on the instrument of torture and twist and twist. It had a swinging-hook that came out at the side of the lever, like a cant-hook, which grasped the tooth, and the more he twisted, the harder it gripped. It would lift one out of his chair if he didn't hang on to the rungs, and after a while something had to give way.

John used to hang on for dear life.

"The old doctor certainly went to the root of the matter," his victim said, reminiscently. 


\section{THE FIRST CIRCUS}

Our lad was twelve years old before he went to a circus. He almost jumped out of his skin when he found he could go, and when the great day arrived-the Day! - he hustled through his chores with amazing speed. Wheedling his mother into giving him his dinner earlier than usual, he did not wait even for a second piece of pie.

Just as he was starting off alone, all a-quiver with excitement, to go across the hills and down to the "Hollow," something happened: His father shouted that one of the new cows had got out and had started back toward her old home.

"Go and head her off-right away!"

"Why can't Curt do it?" John urged, but his father's verdict was uttered in no uncertain tones:

"You've got to get that cow before you go!"

"I ran all the way down to 'Riah Bartram's and headed her off, and brought her back," said he, "and then ran 'cross lots down to the circus, lickety-split."

The circus was down in the village on the great flats where General Training was annually held. (Every spring neighbourhood companies congregated on the flats to go through the manual of arms-Company Training - but in the fall more companies gathered from far and wide for General Training. Echoes from the Mexican War were still keeping up an interest in military matters. The boys thought Major Preston a great soldier as he rode about on his spirited horse like a general on the field of battle.) But General Training was a tame affair compared to a circus! There were the great white tents gleaming in the 
sunlight, the Pepacton* winding in the rear-bustle, gaiety, and throbbing excitement everywhere - the Babel of voices, the splendid gilded wagons, the music of the brassband, the calls of the wild animals - all the novel sights and sounds and smells on every hand! John stumbled over guy-ropes as he hurried along. How his heart thumped against his chest! "By cracky!" but wasn't he glad he was there!

He had no money for side shows, but borrowed a sixpence of Abe Meeker and went into one where he saw a woman handling snakes. They were winding around her arm and writhing in her lap. He also saw a blind girl reading the Bible! Never having heard of this method of reading for the blind, he stood in open-mouthed wonderment watching the girl's sensitive fingers trace the raised letters rapidly while she read aloud from the queer-looking colourless page.

Once inside the magic tent, first one allurement, then another distracted the bewildered boy. What a delicious feeling as he walked over the carpet of straw in the subdued light! Which tier of those seats shall he choose? How can he watch them all? Why do they go so fast?the bare-back riders, the jugglers, the rope-walkers, the acrobats in their pink tights, and the dancers!-It will all be over too soon!

Best of all was the jolly painted clown who jumped and rubbed his legs as if it hurt whenever the Ring Master cracked his whip. John remembers one of the jokes to this day:

"Why is 'lasses candy like a hoss?"

\footnotetext{
* Pepacon is the Indian name for the East branch of the Delaware, which flows through Roxbury.
} 
" 'Cause the more you lick it, the faster it goes,"-and Crack! goes the whip again!

A pity that such delights must end! but long before the show was over John had an uncomfortable sense of preparations being made on all sides for the packing up and moving on. Suddenly he realized that it was all over. How he longed to hang around and see the last of the splendid caravan! Why, all this stir and commotion and lightning speed are as good as the circus itself! But, looking at the sun, he suddenly remembered the chores; he became conscious, too, of a gnawing feeling in his stomach; and, with one long last glance at the hurly-burly on the flats, he faced toward home and slowly climbed the hills, his head whirling from all that he had seen. 
BOYHOOD 



\section{CHAPTER IV}

\section{BOYHOOD RECOLLECTIONS}

From now on John, a lad of eleven, is beginning more and more to want to do things, to experiment, to find out about the myriad forms of life near at hand, and to learn what is going on beyond the hills that enclose his little world. Still, with all his life of activity and enforced usefulness, he remains a dreamer and a saunterer, and, though reaching out in imagination to the cities and towns where the circus goes, he finds endless content in the woods and streams and hillsides on his father's farm. He finds his own thoughts and speculations a never-failing source of interest. The world within is a powerful rival to the world without, and the world of the minute engages him, as well as the world of larger things. A schoolmate of his who sometimes comes back to spend her summers at Roxbury, says she remembers him as a little boy sitting by himself, for long periods, in the school-yard, engrossed in watching the ants in their colonies.

His life during that early period seems to have been a happy combination of dreaming and doing.

\section{AMBROTYPES}

Ambrotypes were old-fashioned pictures made on glass. John's mother had some on the centre table in the "other room." You had to hold them just right or they looked 
like plain glass. The word itself means "an immortal impression."

This is what he has to tell of his own way of making ambrotypes:

I seem to have had the faculty when very young of stamping things on my mind. I remember once when Uncle John and Aunt Abby had been to visit us, as they were driving away I said to myself, "There they go! Look at them! You may never see them again." And it was the last time. It is engraved there as in adamant.

I remember when a boy of twelve, perhaps, stamping Mother on my mind in the same way: she used to come upstairs and tuck Abigail and Jane and Evaline in bed, then come across to us boys and tuck us in.

One night I remember lying there and, on hearing her go to the girls' room, I said to myself, "Now look at your mother-she's going to come out with the candle and stand in the door there-look at her! and remember her when you get old!" I can see her to-day standing there as plainly as I saw her then.

There have been other conscious efforts to stamp things on my mind so that they have never faded-I see them as distinctly as I saw them when a boy.

\section{THE BIG ROCK IN THE PASTURE}

There is a big rock in a hillside pasture over at the east end of the Burroughs farm, near the part of it which for about a hundred years has been called "the Rundle place" (now Woodchuck Lodge); on which as a boy John often sat and dreamed. It is a huge drift boulder of red sandstone dropped there by a glacier tens of thousands of years ago, or "before Adam was a kitten," as the grown-up boy sometimes says.

The everlasting rock, its sheltering iron-wood tree, a perennial spring a few yards away, the wooded hill above, and the great panorama of valley and mountains spread out to view, combined to make a haunt dearly loved by the boy. It is dearer still to the man who climbs there 
now, who fondly calls it "my boyhood rock," and who as the afternoon wanes loves to sit there and watch the shadow of Old Clump thrown on the broad mountain slope across the wide valley.

"Here I climbed at sundown when a boy to rest from work and play, and to listen to the vesper sparrow sing, and here I hope to rest when my work and play are overwhen the sun goes down-here by my boyhood rock."

He used to go there in the spring and listen to the call of the highhole or flicker as it came up from the beechwoods, and in summer to hear the bobolinks as they soared and sang over the high mountain meadows. Sometimes he roamed the meadows in search of their nests, sometimes he found one, though it is the hardest nest in the world to find, so completely is it a part of the meadow bottom in colour and in material. If he did find one, he went there day after day to watch the eggs, and then the young.

Sometimes he loafed for long hours on the rock, speculating with half-closed eyes, as to what the world was made of. Observing the tiny, irregular, drifting forms that floated before his eyeballs, he concluded that those are the stuff of which the world is made. And with all his philosophizing in later years, he says he has not arrived at a much more satisfactory explanation.

In June he often wandered far afield, returning home at dinner time with a lining of wild strawberries in his hat. When he ate those berries in a bowl of bread and milk he was as happy as a king - or as kings were in the days when kings were in fashion. In his trips through the woods he sometimes found a few of the scarce wood-berriessmall, pointed, dark-red and shiny.

In August from his rocky throne on the hillside he 
watched the high-sailing hawks, delighting in their majestic movements. Often he saw one being attacked by a kingbird which would harry it spitefully until the hawk, wheeling, would mount and mount, and the kingbird, losing its reckoning, would abandon the pursuit.

From the same high vantage-ground, before he was old enough to take a hand himself, he looked leisurely down upon the haymakers in the hill meadows.

Some mornings from the big rock he watched the great lake of fog that often settled in the valley. After a while it would begin to stir restlessly in its bed, like a spirit surprised by the rising sun. It ran to and fro, it climbed the hills, it reached helpless arms toward the sky, then cowered again in its bed; but finally some unseen power would lift it and spirit it away, and all the valley would be flooded with sunlight, with only a soft fleecy cloud or two left sailing over the mountain tops.

On sunny June mornings, John would stop near the foot of the pasture where the foundation stones of an old house lay in tumbled piles, and gather from some clustered bushes a large, fragrant, deep-pink rose which he would wear all day in the brim of his torn straw hat.

A favourite resting-place for the lad in his journeys to and from the cow pasture was the Giant Stairs. They were two huge boulders which Time has cut away so as to leave mammoth steps of stone. They still afford a tarrying place by the roadside for the contemplative man.

As Old Cuff usually did the biggest part of the cow driving, John got in the way of trusting a good deal to him while he investigated the flying grasshoppers that in late summer gathered on those rocky stairs during the night. Stealing up there he would catch them before they got 
warmed up in the morning. Curious creatures! Why do the females hover in the air, poised on wing, with shuffling sound? John did not have the patience of a Fabre, or he would have found out, but he never tired of watching them as they worked their curved abdomens into the ground and deposited their eggs there.

\section{A WELL-BUILT DAM}

John wanted a swimming-hole, and as there was none nearer than Stratton Falls, which was too far off, he decided to make one in the pond in the valley below the house. None of his brothers cared about it, so wouldn't lend a hand, but he set at it alone and worked, mostly Sundays, rain or shine, till he had a wall as high as his head, water-tight, built of stone and sod. It was no easy job. He had to carry the chunks of sod a long way in his arms, and the stones, many of which were as big as he could lug. With the farm dogs at his heels, he worked there for weeks, carrying, in all, a good many wagon loads of sod and stone. He was often a sorry sight on coming home from work, for he had to stand in water up to his waist while building the dam.

But it paid, though he usually had to have his fun alone, since his brothers seemed always to have an antipathy for water. Sometimes the Scudder boys from a distant farm came over and went in with him. Sometimes in the sweltering days of midsummer, when haying, he jumped in with his clothes on. It is seventy-two years or more since he built that dam, but much of the old wall is still standing, though the pond in the pasture is long since gone dry. "I builded better than I knew," he said one day as we tarried there at the site of the old swimming-hole. 


\section{AN UNWILLING VOYAGER}

One summer John's ambition for a big kite soared higher than ever before, and he made one three feet long, with a tail of rags, and a half mile or more of string.

Such an airship, he decided, must have a passenger. So catching a meadow-mouse and placing it on the back of the kite, he tied it by one of its legs and launched it into the blue.

What a hop-off for the timid creature who hardly dares show itself above ground five minutes at a time for fear a hawk will pounce upon it! And now-to be suddenly sent up into the very region where those cruel creatures soar! It was surely a case of going to meet danger more than half way.

What a mouse's eye-view it must have had of its sinuous runways in the grass!

He kept tight hold of the long string while the mouse soared aloft, and then, carefully superintending the landing of the monoplane, released the Lilliputian aviator, whose eyes were shining, and tiny heart beating, more wildly than ever.

\section{DARTS AND CROSS-GUNS}

Besides kites, the boys fashioned things they called "darts," which they threw with the hand at a mark. These were made from pieces of broom handle, about six inches long, with a sharp wire in one end, and a bunch of henquills in the other.

They got the wire out of old tin pans or other discarded utensils, and drove it in the handle a good ways, grinding it very sharp on the grind-stone. These could be thrown with force and directness for fifty feet or more. 
They also made what they called a kite (though it bore no resemblance to the regulation kite), which they whittled out from a shingle. It was really an arrow, and they shot it from a bow and string at random in the air.

A much more complicated weapon was a crude crossgun which John made when a small boy-a rather dangerous thing for a lad to handle. He had never seen or heard of one till he made this. It had a lock which he figured out himself. The barrel was made of pine, and the lock of ash, and he whittled out arrows for it. On dropping an arrow into the barrel and releasing the trigger, the arrow would fly far afield. It was fun to drive the arrows deeply into the trunks of trees. He sometimes shot chipmunks with them, bowling over the little creatures as they paused to reconnoitre on the top of a stone wall. It is hard to realize that he could ever have shot this little friend of later years, but the truth must be told-he did it with his little cross-gun. But boys grow wiser and kinder as they grow older, and learn what good chums the chipmunks are if one makes friends with them instead of shooting them.

At that time John made war on them with even a more formidable weapon: A part of his duties when ten or twelve years old (and he did not shirk the duty) was to hunt these little marauders of the cornfield. His father would load the old flintlock musket for him (before he was big enough to do it for himself) with small gravel stones or hard peas, and send him forth to shoot the chipmunks round the corn. Earlier in the season, in March, when the woodpeckers began to drum, John knew it was time for the chipmunk to poke his nose above ground, and for a 
time would not molest him. He delighted in watching the clean, pert little fellow as he stood on the top of a stone wall, eyeing him, with hands beseechingly spread on breast. Let John move ever so little, Stripe-Coat would dart in the wall, or into his hole with a flirt that seemed to the lad as though he slammed the door behind him. The Clever Beasties seemed never more than one jump from home, yet with the old flintlock the boy often severely wounded the little creatures, at a range of six or seven yards, as they peeped at him over the walls.

One day when he was sitting in the bar-way of the horse-lot up by the "sap-bush," watching for chipmunks, a troop of weasels tried to cross there. Of course he fired at them, just to thwart them. He disabled one, but another from the troop, seizing the wounded one, carried it over, and the pack disappeared in the wall. Even a bloodthirsty animal like the weasel, then, has some fellow feeling; as there is honour among thieves, so is there esprit de corps among weasels, and yet this is not always the case: A farmer John knew told him of once coming upon two weasels contesting so earnestly over a mouse that he was able to grab them each by the back of the neck and cage them. The next day, and for two days thereafter, when he offered them food they refused it; but some days later, on going to the cage, he was amazed to find the food still there, and only one weasel, while the bones of the other, picked clean, were lying on the bottom of the cage!

\section{DOWN IN THE BARK-PEELING}

The old bark-peeling was a large devastated place in the valley, in the hemlocks, where the woodmen, after felling the great trees, left them to rot, hauling the bark 
to the tanneries. It was a wasteful practice which would not be allowed in our day with Boy Scouts to spot such senseless waste.

John came upon all sorts of interesting things down there while following the cow paths and the over-grown woodroads, climbing over decayed logs, wading knee-deep through the ferns, and making his way through briers and hazels.

Early in the season he would hear there the rapid copious strain of the purple finch, and wait about till he could catch a glimpse of the shy songster-a brownish bird which, he says, looks as though it had been dipped in diluted pokeberry juice and needed two or three more dippings. In a secluded swampy corner in midsummer he found the purple fringed orchids. The raspberries and blackberries were thick down there, and in berry season there was little loitering; but there were sometimes other things than berries in the bushes: In reaching out his hand for berries, John sometimes put it into a bird's nest. Trout lurked in the brook, squirrels scampered along the fences, foxes left their footprints here and there, and 'coons came down to feed and splash in the stream; turning the stones over with their noses, they rooted like a pig, in search of food beneath the stones.

One midsummer day as John loitered in the bark-peelling he was startled by a whirr, and spied a brood of partridges (ruffed grouse) scattering in every direction. Hiding behind the ferns he listened while the wild hen called together her brood. That soft, persuasive cooing of the hen, then the faint, timid Yeap of the young! Now the cooing grows louder, now it is a clucking call, and the chicks move cautiously in her direction. But as the lad 


\section{JOHN BURROUGHS-BOY AND MAN}

steals from his hiding-place all sounds cease-the wild bird and her brood elude even the wary boy!

But the male partridge as it drummed on a mossy log did not always elude him. Many a time when skulking under the hemlocks he caught the drummer in the act. Standing erect on a decayed log, expanding its ruff, and spreading its tail, the bird would give two introductory blows, pause, then resume, striking faster and faster, till the sound became a continuous whirr, lasting a half minute or more. The bird's wings barely touch the log-the drumming sound is produced by the force of the blows upon the air.

\section{THE GRAVEYARD AND THE HAUNTED BARN}

Even when in his early teens, an unwelcome companion named Fear used to hover about John at nightfall. By day he would go over to Uncle Henry's, marching up the hill and around the little old graveyard as boldly as a soldier, but on his return at dusk Fear would suddenly approach, nudge him, and remind him of the frightful tales Granther Kelly used to tell. One story of Granther 's which made his blood run cold had a way of coming to mind just as he rounded the bend of the road by the lonely graves: Once, in Granther's youth, when he was going by a cemetery one pitch-dark night, all alone, with no sound to be heard but the hoot of an owl in the nearby woods, he suddenly saw a light rising above a low headstone. It moved swiftly. It came his way, rolling and tumbling as it came, and all of a sudden whirled by him in the road. It was a big ball of fire- "monstrous big, as big as a wash-tub!- some Evil Spirit that could not rest in its grave!" 
This gruesome recital, told as only Granther could tell it, and emphasized with his "Zounds!" and "Zuckers!" seemed to John to have happened in that very locality. How he tiptoed around the bend of the road lest a gang of ghosts dog his heels! but when he got down the road a ways how he did cut and run!

Darkness always held such shapeless, nameless terrors for him! To go alone along the edge of the beechwoods at nightfall was a frightful experience, though he preferred roaming the woods alone by day, or with only Cuff, the yellow, bob-tailed mastiff, or Spot, the hound, for companion. And how he dreaded cleaning the stables in the big barn on the hill, even in the day-time, because of that great black hole underneath!

He envied the happy, fearless eave-swallows, diving in and out of the barn, chattering and squeaking as they built beneath the eaves. They could dart out and off in a jiffy if they saw anything unpleasant in there. Poor lad!

Peering timidly into that black abyss, fearful of what might be lurking there, he would send Cuff in first to scare 'em out, before he tackled the job. Once in there, he worked as Hercules worked at a similar task, breathing freely only when again under the open sky with the phantoms behind him, and the light of day enveloping him once more.

\section{THE RIDE TO CATSKILL}

Put yourself back, if you can, to those days of John's boyhood, say in 1848, when there were few railroads in the country, and none nearer his home than fifty miles, no cheap post, no free press, no telephones, the telegraph 
just beginning to be known, no phonographs, no wireless, no trolleys, no bicycles, no automobiles, no aeroplanes, no dirigibles, no electrical contrivances, no Movies!!! no battleships, not even any ocean liners-just sailing vessels. In fact, there were none of the thousand and one other things that boys are interested in nowadays. Realizing the difference, perhaps you can imagine how much a long ride in his father's farm wagon, through a strange country to a town that seemed very big to him, would mean to him at eleven years of age-how real an adventure it was.

Perhaps you think his boyhood must have been a tame affair, but it was not. Life itself was one big Adventure to him; for that matter, it is so still. He has never reached that dull time when he complains that "there's nothing going on." The universe is going on; there are a number of things, little and big, to claim his attention. As boy and man he has always felt a lively interest in the Big Show.

That journey to Catskill was at the time the biggest thing that had happened to him. It was a ride of fifty miles-the annual fall trip which his father made to take a load of butter to the Catskill market.

He dreamed of that journey for weeks ahead. His elder brothers had made the trip one by one, on previous years, and wonderful were the tales they told of what they had seen. Now it was his turn. He was to see the sights of the town of Catskill, the Hudson river, and a steamboat!

Such a state of excitement as he was in as the momentous day drew near! Would his mother have his clothes ready? Would the weather be too cold? Would the world come to an end before the hour of starting? In fact, he 
was, as his brothers said, in a dreadful pucker those last few days.

The day before starting he went up in the woods above his boyhood rock where he so often idled and dreamed, but this time there was no dreaming or dawdling. He had the old musket in his hand which his father had loaded for him, and he had a definite errand: he was after game to add to the provisions they were to carry on the journey.

Sitting on his haunches on the edge of the woods he watched and waited, but had not waited long when he spied a partridge on a log, her mottled plumage blending with the bark and weeds. "Quit, quit, quit," she called. Resting his gun on a little bush about two feet high, John was about to shoot when a twig broke, letting the gun down in the leaves.

"Don't hurry, little boy-I'll wait," the bird seemed to say. So getting his gun up again he shot. The bird fell off the log and fluttered in the leaves just as a hen flops about when her head's cut off.

His first partridge!

Surprised at such good fortune, he took the partridge by the leg, shouldered the musket, and started for home, almost walking on air.

In going past the beechwoods, hearing a great commotion among the crows in the woods beyond, and guessing that there was something unusual over there, he ran to see what it was. At his approach the crows scattered. While he stood looking about for the cause of the cawing, out of a stump close by came a great horned owl! The owl looked at John, and John looked at the owl which turned and softly flew to a tree where it sat and solemnly bent its blinking eyes upon the lad. 
Bang! went the gun! Down fell the owl!

Triumphantly the young Nimrod marched home with his brace of birds, but they only cooked one of them.

On these trips to Catskill the thrifty farmers took along their victuals for the four days instead of squandering their money at the inns, though they did have to expend a shilling for lodging, and another shilling each for breakfast.

How the lad worked the night before starting to help load the heavy firkins on the wagon!

They took a ton or more of butter-twenty firkins-to Catskill every trip, and usually made two trips in the fall, in the spring selling their butter at Roxbury. The price they got for butter in those days was sixteen to eighteen cents a pound for fall butter, and twenty cents, as a rule, for spring butter.

The next morning before daylight the big box of food was stowed away in the wagon, and oats for the horses. John put on the old family overcoat which all the boys, in turn, had worn on this trip-a coat with a tremendous collar, made by the neighbourhood tailoress, from the wool of their own Merino and South-Down sheep.

When all was in readiness, and his mother had reminded his father for the last time of the purchases he was to make, they set out. There was one purchase which, as we shall see, the boy was not likely to let his father forget.

The wagon rattled over the frozen ground, and John, a happy, eager, wide-awake boy, perched on the high spring-seat, took in the wonders along the way.

They stayed at the tavern at Cairo over night in going, and at Steele's tavern, near Ashland, on the return trip. Other farmers were at Cairo, too. In the morning John 
overheard his father bragging to them what a smart boy he was for his age. Soon after his father told him to go to the barn and drive out the team. Anxious to justify the praise he had heard of himself, he got nervous, bungled in driving out, and struck the hub of the wheel against the door-jamb, to his own and his father's mortification; so it was a crestfallen lad that surrendered the lines to his father as they drove off. But as they crossed the Catskill mountain and looked down into the great valley of the Hudson, John forgot his troubles, carried away with the glory and the wonder of that view!

Catskill was by far the biggest town he had ever seen. The noble river itself was a revelation to him-to this boy who had been till now shut in by the mountains! His imagination went cruising away to the sea with the white sails, and the wheeling gulls that he beheld for the first time. And yes, "By cracky! there's a steamboat! and a train of cars, far away, across the river!" Life holds few richer moments than this!

Awed by the strangeness of all that he saw, John stuck pretty close to his father. But while standing on the street waiting for his father to come out of a store, he was hailed by a drover passing with some cows:

"Hey, Bub! turn them cows up that street, will ye?"

Now John was used to cows, so did it in a jiffy, glad of something familiar in this strange scene. The drover gave him four copper pennies for the job.

The altercation which his father had with Old Dowie, the butter buyer, left a lasting impression on the boy's mind: As they were unloading the butter, Dowie questioned the weight of a certain firkin. (The weight of butter and firkin was marked on each firkin, after which the 
firkin's weight was deducted.) A hot dispute arose between Farmer Burroughs and Old Dowie over the suspected firkin, and the farmer, angered at his honesty being questioned, shouted: "We'll strip it off and weigh the butter!" And he did.

There stood the naked butter on the scales. John, looking anxiously on, was greatly relieved when the scales showed that the butter weighed what his father had claimed. Old Dowie grunted, and Farmer Burroughs looked triumphant as they put the exonerated butter back in the firkin.

After that there was the marketing to do-a barrel of flour to get, salt, tea, and other purchases, to carry back in the otherwise empty wagon box. (They had no coffee in those days; the tea used was green tea.)

Driving down to Catskill Point, they bought several hundred herring to be salted down at home. They also took back gypsum to use on the fields. And there was clothing to purchase, calico and delaine for Mother and the girls, boots for the older boys, and a new cap for John. It was a wool cap trimmed with a band of musk-rat fur. With what pride he wore it on the return trip!

It was dark on reaching home after the four eventful days. When they reached the crest of the big hill and saw the lights in the windows, the old place looked very good to John, experiencing his first home-coming.

The loud rattle of the wagon brought his mother and the girls and boys to the door. Shouts of welcome greeted the cold and hungry travellers. Hiram lighted the candle in the old tin lantern and brought it out to the barn. While he and Curtis helped to unharness and look after the horses, Eden and the girls carried in the purchases. 
John sought his mother's side and showed her his furtrimmed cap. Soon all were seated at the supper-table. discussing the trip and the food with lively dispatch.

\section{THE BATTLE OF BEARSVILLE CREEK}

In his twelfth year when John went with a drover to take his cattle to Moresville (now Grand Gorge), ten miles from home, he had a real adventure on the return trip:

After having been paid off, he strolled about the little village eating his lunch of crackers and raisins, and taking in the novel sights.

Nearing the bridge over the creek and seeing some village boys congregated there, he lingered to scrape acquaintance. Presently a large group of children, little and big, collected on the bridge. They stared at the strange boy. Who is he? Where does he come from? What is he here for? their looks seemed to say. He felt vaguely uncomfortable. There seemed an unfriendly feeling in the air.

Soon the larger boys edged nearer and challenged the newcomer to jump with them. This was better; he felt easier already. Jumping, he cleared their farthest mark. Emboldened by his success, he gave them a sample of his stone-throwing. They threw stones, too, but he excelled them all. This didn't set well, and John grew unmistakably aware that the entire crowd was against him.

The little girls and boys began, half-playfully, halfspitefully, throwing pebbles and lumps of earth at him. Soon they ran up and switched his legs. Then they struck him tentatively with sticks. Then the larger boys took a hand; finally the whole pack was arrayed against him. 
Keeping them at bay awhile with a stick, as he saw the feeling rising higher and higher, he suddenly broke through their ranks and made for home, the hostile pack at his heels, wildly throwing their sticks and stones.

Gradually the girls and the smaller boys dropped out of the race, then some of the larger ones till, at the end of about fifty rods, only two boys about John's size were hotly pursuing him, wrath and determination in their faces.

On he ran as though ghosts and hobgoblins were at his heels. At length, he outdistanced his pursuers, and they turned back, permitting him, badly wounded, to continue his homeward journey in peace-not a very famous victory, perhaps, for our hero, but surely discretion was the better part of valor here.

\section{A GLORIOUS FOURTH}

The Fourth of July when John was fourteen years old was a memorable one for him. He was granted three days off with Rube Scudder, a boy about his age. He and Rube debated the question for days as to where and how they should spend the time, finally deciding on a long hike to Lexington, where Olly, John's married sister, lived.

John and Rube were fast friends. They had swimming matches sometimes, and often roamed the woods together. Rube was always good company; he could dance the "juba" as well as the men in the shows could.

John had a brand-new straw hat for the occasion, and wore his new suit of Kentucky "Jane."* Of course the boys usually went barefoot in the summer. To save shoe

* (Jean) -a kind of cotton cloth dyed with walnut bark which was bought by the piece, cut by the village tailor, and made up by Mary Montgomery, who came to their house every year for a fortnight and helped his mother make their clothes. 
leather? Yes, but also because they liked it. Oh, that feel of the earth to his bare feet as he ran up and down the red road for the first time in the spring! but for this momentous outing he wore his cowhide boots made by the cobbler in the village.

Rube stayed with John the night before. Starting out at sun-up, after a hurried breakfast, the boys went down by Hardscrabble Creek, crossed the flats and on up through Montgomery Hollow, through Wild Cat Pass, down into Johnson's Hollow, and on to Lexington, twenty-five miles away.

It took them all day to go. The rye bread and butter and maple-sugar cookies which they carried in their pockets disappeared long before they had gone half way, but they picked berries, ate spearmint, regaled themselves with Adam's ale at many a delicious spring, and were as happy as boys on a holiday usually are, and perhaps a bit happier. They never had had three days off before! They were rich, too-each boy had a sixpence in his pocket with which to celebrate the Fourth!

In the mountain meadows bobolinks were singing their gayest, summer being for them a perpetual Fourth of July. One of Rube's stunts was to mimic the bobolinks. Pausing amid their berry-gathering, the boys rested in the sunny meadows, while Rube called out:

Pe-teu, pe-teu, pe-timble, pe-timble, pe-timble! spiddleywitt, spiddley-witt, spiddley-witt, witt, witt, witt, phee, phee, phee!

The next day the boys were up bright and early to see the wonders of the town of Lexington, and hear the spread-eagle orator hold forth. They stood in openmouthed wonder at his sweeping gestures and the steady 
outpouring of his big words, especially delighted when he talked dramatically about hanging some one as high as Haman; they wondered how high that was, and where it was that Haman was hung, and what they hung him for. John wondered if that was the hanging over the Delhi that his father and Aunt Mary once went to see, when Aunt Mary fainted away at the wrong time-just as the man was swinging off! He had heard the story many times, but was uncertain whether or not the man's name was Haman.

They saw a real cannon fired at a mark on the side-hill half a mile away - a brass six-pounder, and searching out the spot, tried in vain to dig the balls out of the ground into which they were lodged.

On the third day they reluctantly faced homeward.

A young fellow in a buggy overtook the pedestrians, giving them a lift as far as Prattsville where, stopping at a tavern, he announced that that was as far as he went, and that now it was their turn to treat. Treat! their sixpences were spent two days ago! Confessing that they had nothing to treat with, Rube and John slunk away in humiliation, and trudged on home, their spirits a little dampened by the encounter. But in the meadows, with the sun shining and the bobolinks rollicking, and with all they had to talk over, they soon forgot that passing cloud, so it was a glorious Fourth just the same! 


\section{CHAPTER V}

\section{WAYS AND MEANS IN JOHN'S BOYHOOD}

SEVENTY and eighty years make quite a difference in the customs and methods of people living in the same locality and following, in the main, the same pursuits as their ancestors. Our ways and means to-day seem quite commonplace to us so accustomed to them, but eighty years hence they may hold a great deal of interest for our children and grandchildren, just as the way they did things when John Burroughs was a boy interests us to-day.

\section{BAKING DAY}

In those days they could not step out to a grocery and buy a loaf of bread. It would not have gone far in such a big family. A baking - ten big loaves of rye and two of wheat-had to be pieced out with pancakes, Johnny cakes, and biscuits.

On baking-day the old kitchen was all a-bustle. The great brick oven was heated piping hot before the bread went in, by building a fire in it where the loaves were later to go. Such a skurrying as there was among the boys when their mother called for more and yet more light, flashy wood!

"One more armful-quick!" she cried, when they would think their job done. Then they watched her as, opening the door and testing the oven with her hand, she 
pronounced it hot enough; quickly raked out the coals and ashes, and put in the loaves with the long-handled iron shovel. An hour later, when the big wooden door was opened, and the brown crusty loaves drawn out-was there ever a more delicious smell!! And sometimes Mother Burroughs cuts one of the warm rye loaves for her hungry boys - "Um! Um! Guess I don't mind getting oven wood, after all!"

There was also a little Dutch oven made of tin, closed at the sides, back, top, and bottom, like a little shed. This was set down with its opening close to the fire; in this their mother could bake Johnny cake or biscuit in a hurry, when company came unexpectedly.

\section{DAIRY WORK}

Before John was old enough to do any milking, he saved his mother many steps by helping with the pans. There were about ten pailfuls of milk at each milking, morning and night; it took four pans to a pail, so there were forty milk pans to skim and wash twice a day. Starting to skim about three in the afternoon, it usually took her an hour, with John carrying the pans. A boy had to mind his p's and q's with those full pans. Perhaps it is due to that early task that we never find him "slopping over" in later years.

How deftly his mother skimmed the cream! With a case-knife she would sweep around the pan, then slip the thick yellow mass, looking like a leather apron, into the cream-jar. When the milk was "lobbered" they saved out some for pot-cheese, and ate some, sweetened with maple sugar, as "bonny clabber," but the most of it, with the skim milk, was fed to the pigs. 


\section{THE DOG-CHURN AND THE CHURNERS}

In summer the butter was made by means of the dogchurn-a large wheel set at an angle, which went round and round as the old mastiff, standing in one place, would tread it. The cogs on the wheel turned a shaft which had a crank, the crank worked the sweep, and the sweep lifted the churn-dasher. It was a dull, tiresome round, even for a dog, usually taking half a day. Old Cuff got so he knew when churning was to be done and at such times contrived to have important business with the woodchucks in a distant field.

When Cuff quit his job they pressed an old ram into the service, but after a time he proved fractious, hanging back and settling down and refusing to make the wheel go round. When that was the case, John and Eden had to take their turn at the tiresome treadmill. They soon learned to outwit the balky fellow: Rigging up the hetchel behind him so that when he started to settle down the teeth of the hetchel would prod him sharply, they forced him to do his stunt, willy-nilly.

There came a day when, utterly weary of the many unlucky turns of Fortune's wheel, the ram decided to make an end of it. He jumped off the wheel and hanged himself with the rope by which he was tied. John and Eden, for reasons, mourned the death of that ram more than did any others in the Burroughs household.

(Once when Mr. Burroughs was past seventy I was with him in an old mansion at Johnstown, N. Y., where numerous implements of auld lang syne were on exhibition -spinning-wheels, looms, distaffs, swifts, warming-pans, horse-pistols, and so on-and when some one asked, 
"Have you ever seen a dog-churn?" he retorted quickly, "Yes, yes, and I've been the dog," and fled down the attic stairs as though afraid of being pressed into service again.)

In winter and early spring when there was less milk, they used a hand-churn, and two of the boys had to ply that dasher up and down interminably-work which they cordially disliked. They did not dislike the delicious buttermilk, though, with the little flecks of butter swimming about in it, which their mother dipped for them from the old blue churn after their glad shouts of triumph-"Butter's come!"

\section{CHEESE-MAKING}

John's mother made cheese only three or four times a year; they could not afford it oftener as it took a whole milking.

Into the big kettle of milk went the rennet (the dried stomach of a calf) to curdle it. When it was a solid curd, John would dip out the thin yellow whey and feed it to the pigs, taking frequent toll of the sweet curd as he dipped. One day he took such heavy toll he was completely cloyed, and it was a month of Sundays before he wanted to taste it again.

The curd, suspended in an old table cloth, dripped for hours, and then was packed in the big hoop, or cheese mold, and put in the press; a kettle filled with stones hanging on the end of the lever of the press affording the weight. The green cheese stood in the press for weeks, and when released was dry and solid. Stored in the back bedroom, it was not cut until seasoned, and then only when company came.

"And that's the cheese of it," was slang in John's boyhood. 


\section{CANDLE-MAKING}

The boys liked to watch their mother make candles.

"Go and fetch me the rods and bars-I'm going to dip candles this afternoon,". their mother would say, and John and Eden would bring the candle-bars and the bundle of candle-rods from the attic, placing the bars with their ends resting on the backs of chairs, in readiness to support the rods. These, about three feet long, were whittled by the boys out of elder wood.

The tallow, obtained from a beef they had killed, was put into the big caldron of hot water. Twelve pieces of wicking about sixteen inches long were hung over each rod a few inches apart, and twisted and tied. (This left a loop at the top of each candle, which had to be burnt off when first lighted.)

The boys made themselves useful in handing the rods to their mother, who, after dipping the dangling wicks in the melted tallow, rested the rods on the long bars. By the time she had dipped them all, the first rod-full was ready for the second dipping; and so on till all were dipped thirty or forty times. It was fun to see them grow bigger with each tallow bath till large enough to fit the candlesticks. Sometimes, looking critically at a rod-full, she would decide that they needed one more dip, so in they would go again. When they were cool enough, she would carefully straighten them, and John and Eden would slip them off the rods, smooth the butt ends, and pack them away from rats and mice on a shelf in the wash-house. Many a time of a winter evening John would hear the familiar injunction, "Run and fetch a candle, John-this is 'most burnt out." 
Those dipped candles looked quite different from the symmetrical paraffine candles we use to-day; yellowish white, and bigger at the butt-end, they tapered to a rather small calibre at the top. Because of this slender top, they would burn down very fast when first lighted. The wicks, much larger than those of modern candles, were "big as a rye-straw," and required frequent snuffing. Farmer Burroughs used to do it quickly with thumb and finger, and John himself got so he could snuff them deftly without burning himself, but his mother and the girls used the brass snuffers on the mantelpiece.

Later the farmers' wives bought tin moulds and, arranging the wicks in them, poured the tallow in the mouldsa much quicker process, and one resulting in candles of uniform size.

The iron candlesticks had an arrangement on the side for moving the candle up as it burned away, and at the top was a little hook by which they hung the candlestick to the back of a chair. It was extravagant to have more than one candle lighted, unless there was company. Of an evening, John would bring his book and sit close to his mother as she sat mending and leaning toward the chairback where the lighted candle hung. The round base of the candlestick was sharp on the rim. They used this rim to scrape the bristles from the hogs' backs at hog-killing time.

\section{SOAP-MAKING}

The boys helped with soap-making by filling the leachtub with ashes after having put in straw through which to strain the lye. The leach-tub was usually a hollow basswood tree which held many bushels. It stood on a slant with the smaller end down, on a big flat stone out by the 
wash-house. A groove in the stone conducted the lye to a big cauldron. If a suitable tree could not be found, a triangular tub was made by a carpenter-a reversed truncated cone, held together with a square frame.

The ashes in, they poured water through from time to time, and after a while, out from below flowed the dark brown lye. They judged when this was strong enough by dropping in an egg which floated only when the lye was of the required strength.

Into the cauldron with the lye they dumped all the grease collected since the last soap-making; all the scraps tried out from the lard since hog-killing time-ham rinds, pork fat, and all other waste grease-in it all went. Then, with a fire under the kettle, someone stirred the mass with a long stick from time to time. From this there finally resulted the brown, jelly-like, slippery soft soapthe only soap which they had to use. A little wooden dish of it always stood on the end of the wash-bench in the kitchen, and when the boys wanted to scrub up, they would dip in their fingers and besmear their hands with the glairy, strong-smelling liquid. There may have been some kind of toilet soap in the best bedroom, but if there was, John has no recollection of it now.

\section{FRUIT-GATHERING}

The boys and girls helped with fruit-gathering and drying. John and his mother usually gathered the most of the berries, for, as has been said, he was her best berrypicker. He knew where the biggest berries grew. Day after day they would go out in the hill-meadows and down in the bark-peeling. Oh, those strawberry days amid the daisies, the tall timothy, and the bobolinks! There was 
no other berry John liked so well, it delighted so many of his senses; eye, ear, nose, and tongue came in for their share; beautiful as a flower to look upon, it snapped and crackled as he severed it from the stem; it smelled-Oh, how good it smelled! and tasted!- -but there's no describing its taste! A handful of the dead ripe berries in a bowl of bread and milk, and the king in his parlour eating bread and honey were an object of pity in comparison!

They went along the borders of the fields for "rozberries," down in the bark-peeling for blackberries, and up on Old Clump for huckleberries. In these excursions John always brought home a good deal besides berries, yet always had a heaping measure of them.

The girls had the dull work of looking over the berries and spreading them on plates to be dried in the sun, or, after the advent of the kitchen stove, in the oven. The berries had to be stirred and turned till thoroughly dried. That was drudgery. John had the best of the bargain.

When they dried apples, Hiram, the handy one, pared them, sitting astride the machine he had made, while the others cut and cored them, stringing them on heavy linen thread, after which they were hung on poles and suspended from the kitchen ceiling. Hiram also made the knives for the machine from parts of an old scythe-blade. None of the farmers anywhere round had as good paring-knives as Hiram's. He was in great demand at the apple-cuts.

Our lad always had a sweet tooth, but it wasn't often catered to. "Lock jaw," made from maple sap, and wild honey were the lollypops that Mother Nature offered him, but there was little candy or sweetmeats, and little canning or preserving in those days. Store sugar was 


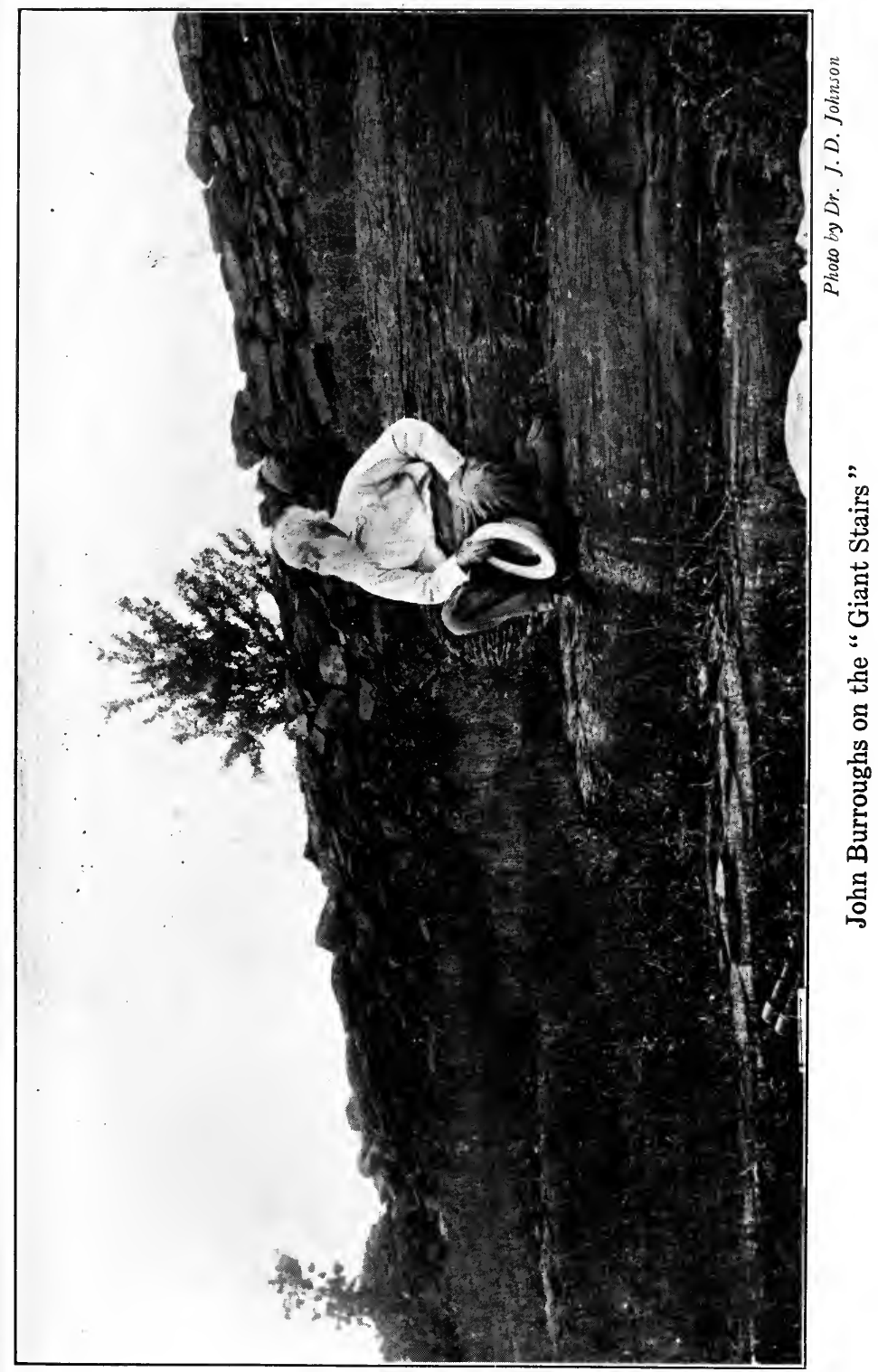


John had a hankering after them which grew as the pears grew. Their scheme was this: Jane was to go to the house and engage "Aunt" Dolly in the liveliest conversation of which she was capable, while John was to whisk around to the pear tree and occupy himself diligently for a brief but fruitful period.

While fulfilling his part of the bargain with the utmost diligence, likewise pockets, and stomach, wondering meanwhile what topics of conversation were occurring to the none-too-ready Jane, behold what John doth see- "Aunt" Dolly, rushing around the corner of the house, her white cap flopping indignantly, her tongue lashing unstintingly! The fruit-gatherer, standing on the fence, with protruding pockets, is suddenly arrested. Apparently his labours in this line are at an end. He is speedily persuaded to come to the ground. He is furthermore persuaded to empty his pockets of every last pear. One by one they go reluctantly into "Aunt" Dolly's out-held apron. Discomfited, Jane and John return across the fields, a sorry pair (poor Jane, after all her efforts, not having had a single taste!), while "Aunt" Dolly triumphantly carried the gathered fruit into the house.

\section{THE OLD-TIME WATER SYSTEM}

In John's time the water was brought down to the house from the spring on the hillside in a primitive way, by means of pump-logs bored out with an augur and laid in a trench under the ground, thence conducted to the penstock-an upright hollowed-out poplar log into which the water poured through a strainer, and from which it flowed out of a spout into the watering-trough at the rear door. When Farmer Burroughs had to renew his pump-logs 
he would take the boys with him up on the mountain and cut and haul down the "popple" logs, after which a man from Moresville came with his big augur to bore them. It was great fun to watch the man with his fifteen-foot augur bore the holes. John remembers the laying of two sets of pump-logs in his time, besides the occasional boring of some which would decay from time to time.

\section{PICKING GEESE}

"John, you and Eden go and shut up the geese-I'm going to pick them after dinner," their mother would say, and such a squawking as was heard when the boys drove them into the stable!

Sitting on a low chair in the barn, and, taking a struggling goose from one of the boys, tucking its head under her arm, their mother deftly and quickly plucked it on belly, sides, and back. It was a sorry sight when plucked! Shouting derisively, the boys would liberate it, bring her another protesting victim which, in time, they would let out to its fellows, squawking as it went. When she plucked the old gander, disreputable as he looked, he always returned to his wives bragging ludicrously, though what he had to brag about, unless that he had escaped with his life, was hard to guess.

The feathers were later made into beds and pillows. It was the custom in those days, besides keeping up the supply for the family, to make extra beds and pillows, from time to time, so that each boy and girl, when married, could have a feather-bed and a pair of pillows. John's head for many a later year rested on the feathers of those squawking geese he had coralled for his mother to pluck. 


\section{THE BEDS OF AULD LANG SYNE}

Spring beds were unknown in John's boyhood. The four-posted cord-bedsteads, mostly of cherry (mahogany only for the well-to-do), were strung across and criss-cross, making squares of strong cord which supported the mattress, or straw-tick. The bed-cord was tightened with a home-made tool fashioned for the purpose. In winter, feather-beds were used on top of the straw-ticks. Sometimes a corn-husk mattress was used in place of, or above, the straw.

From time to time the oat-straw had to be renewed, for, when broken, it matted and became lumpy. It was then the boys' stunt to take up their beds and walk with them to the stables or the pig-pen, where henceforth the straw served as bedding in a humbler capacity. The ticks, filled with fresh, springy straw-oh! how luxuriously they sank down into them at night!

Their pillows were of goose-feathers, the sheets and pillow-cases of home-made linen, made from flax which the boys had helped gather, and their mother had spun. The patchwork quilts, pieced by the girls and their mother, were quilted by friends and neighbours who came to the quilting-party from miles around. Willingly the boys brought down the quilting-frames from the attic and set them up in the "other room," knowing that, besides other goodies, they were pretty sure to have white bread, new cheese, and preserved pears for supper! The comfortables, wadded, chintz-covered affairs, sparsely tied with bits of bright-coloured yarn, were also tied off at the quilting-bees.

Over quilts and comfortables was spread the blue and white "kiverlid" woven from the wool that grew on the 
sheep which the boys had chased over the breezy hills, driven to be washed in Hardscrabble creek, and collected in the barn to be sheared.

"As ye make your bed, so shall ye lie in it." I wonder if sleep would not be a little sweeter and sounder on such a bed, home-made and home-grown, than on our spring beds with glittering brass bedsteads, hair, or felt, mattresses, ready-made sheets, rose blankets, and the modern counterpane. But a boy's sleep is pretty sure to be sound and sweet anyhow, whether he rest on an up-to-date mattress or on a downy bed of Auld Lang Syne.

\section{NEIGHBOURHOOD CHARACTERS}

There was "Aunt" Debby Scudder who lived alone in a little brown house over on the cross-roads. She kept six cows, milking and foddering them herself, worked her own garden, and did many a job ordinarily done by men, doing the work well, and letting neither the grass nor the weeds grow under her busy feet.

She was a meek and pious soul, yet one Sunday as the Burroughs family were driving by in their "pleasure wagon,"* on the way to the old yellow meeting-house at Shacksville, they were dumbfounded to see "Aunt" Debby out by the side door, rubbing away at the wash-tub.

"Deborah Scudder! what do you mean by washing on Sunday?"

Throwing up her hands dripping with suds, "Aunt" Debby cried aghast, "Sunday! is to-day Sunday?" When convinced that it was, without another word she dried her

\footnotetext{
* A three-seated wagon, made by hand, by Nell Dart, and taken to Enderlin's blacksmith shop in the Hollow to be "ironed." It cost seventy-five or eighty dollars, a good deal of money then, and was the source of pardonable pride to any farmer thrifty enough to own one.
} 
hands on her apron, left her tubs without a glance back, and hurried into the house, presumably to wrestle with the Lord for her offence in having broken His Commandment. Certain it is she did not go to hear Elder Hewitt that day.

The boys went to church only occasionally, walking across lots (which compensated some), while their parents and the girls rode in the pleasure wagon. Groaning in spirit to exchange the sunlit fields for that ugly old church, they seated themselves in the gallery where they could look down upon the worshippers (the men on one side, the women on the other), managing, somehow, to live through the two long hours that Elder Hewitt spent in his chaotic discourse. "He was a solemn old raven, but a man of solid worth and sterling qualities," said the man who sat so unwillingly under his preaching as a lad. He never got anywhere. There was no reasoning-just a lot of texts strung together, with occasional emotional outbursts. These outbursts were oases in the solemn, lugubrious delivery that at last came to an end and let the sufferers escape into the sunshine again.

When the old elder had his fling at the unregenerate Armenians, as the Methodists were then called, the boys liked it immensely, for then there was some "git up and git" to what he said. How he used to roll out those magic words, "foreordination," and "predestination"-words which meant that the chosen few, the Old School Baptists, had their names written forever in theLamb'sBook of Life! Their "calling and election" were sure. That sect, to which John's parents belonged, believed that one was "saved by grace," not by "works"; that there was no such a thing as "free salvation," as the Armenians ad- 
vocated, but that one's name had to be on the roll-call from all eternity, if one was to be saved.

The Yearly Meetings were welcome breaks in the usual solemn Sunday observances, the human element being more in evidence then. The families would come from far and near; the sheds and the church-yard, too, would be filled with wagons and horses. Each family brought great baskets of provisions. Although the forenoon and afternoon sessions were long, drowsy affairs, the noon hour, with the decorous picnic on the grass, atoned for a multitude of texts. Then the men stood or sat around on the ground, discussing the weather and the crops. The women bustled about, spreading out the victuals, and gossipping about their weaving and dyeing, their patchwork, and their carpet-rags. The hungry boys hovered near, eyeing the good things which made their mouths water, and longing for the time when, the long grace ended, they could fall to and dispose of the things predestined to be devoured. After that the men lounged about and smoked, the women walked reverently among the graves of kindred and neighbours, speaking in low tones, sometimes secretly wiping away a tear, pulling a weed here and there, and reading over the lines on the headstones. Then it was that the boys quietly stole away to Stratton Falls, their absence from the afternoon session being tacitly agreed upon. Once there, forgetting all about the weighty doctrines Elder Hewitt was so earnestly expounding in the dismal church, they gave themselves up to the good times it was foreordained from the beginning that boys in all ages shall enjoy.

Sometimes instead of going to church at Shacksville the Burroughs family rode over to Brag Hollow to hear 
Elder Jim Meade hold forth. John's father was sometimes so carried away by the eloquence of this simple, fine old man, that he knew not whether he was in the body or out of the body. The Elder worked his little farm on weekdays and preached on Sundays. Coming into the schoolhouse barefooted and, standing up among his neighbours, he would open his mouth and trust to the Lord to fill it, while his hearers sat awed by his homely eloquence.

Sylvester Preston, the carpenter who built the wagonhouse for John's father, was quite a wag and had his little joke at the expense of Farmer Burroughs:

"Chauncey, it's the rule for a carpenter to take home twenty nails with him every night, and I shall have to follow the rule," he said, as the first day's work was drawing to a close.

"By Phagus!" ejaculated Farmer Burroughs, as he thought of how much those wrought nails cost, and what an item it would be before 'Vester got the wagon-house done. But he added resignedly, "Well, if that's the rule, 'Vester, I suppose you'll have to," and he went about with a worried look, helplessly pondering the injustice of it. When night came he stood there ruefully, expecting to see Sylvester take his twenty nails. Then, with a loud guffaw, the carpenter made him understand that the nails he was to carry home were those which Mother Nature had forged for him, and that he would bring the same ones back with him every morning. 


\section{CHAPTER VI}

\section{CHORES AND PASTIMES}

BEING a boy is pretty much the same everywhere. The odd jobs so easily turned over to the boy differ in different places and times, but, as a rule, since Cain and Abel were "kids," boys have been expected to do the hundred and one things that no one else seems to have time, or inclination, to do. Whatever inner rebellion is feltrat the unending nature of the chores, most boys face the music and do their stunts, and still squeeze out time for more important matters.

Our boy was no exception to other boys when it came to a choice between chores and pastimes; he found joy in the things that boys usually do, and found certain tasks irksome, as boys do, have done, and will do, the world over; and yet, much of his work was play, or if not, he managed, somehow, to get a pretty full measure of enjoyment even though not escaping the work.

Sometimes his father found him dreaming under the apple trees, or behind the wood-pile with a book, the chores still undone, and an uneasy fear haunted him concerning the lad; he was afraid John would never be a good farmer, and, with that queer hankering after books, might even become a Methodist minister. To an Old School Baptist like Farmer Burroughs, that was about the worst end imaginable! Why, John sometimes saw his father and their Methodist neighbour, Jerry Bouton, almost come to 
blows as, sitting with Bibles on knees, they argued hotly over "free salvation," "predestination," and other religious beliefs in their diverse creeds.

Farmer Burroughs believed that all his other boys would eclipse John: There was Hiram who did so many things well. He was handy at making all sorts of implements used on the farm which had to be made by handneck-yokes, axe-handles, hay-rigging, cradle-fingers, sledrunners, and so on. And he could graft trees, blast rocks, and lay stone walls, in none of which things John showed any aptitude.

Now, while it is true that John never acquired Hiram's skill and handiness, nor Wilson's boldness, thoroughness, and thrift, nor Curtis's expertness as a milker, nor Eden's orderliness and system, yet, as a matter of fact, he equalled and even excelled his brothers in much of the farm work, in spite of his thirst for knowledge. He usually tackled his jobs, when "forced put," with more vim than the others showed, as well as with more "gumption," chiefly because he wanted to get through with them and get to something more interesting. Tasks were, with him, nearly always means to other ends, and with these ends in view, he could keep his nose to the grindstone, saw wood, hoe out his row, plough a straight furrow, and cut as broad and clean a swath as the next one.

There were a few things he failed to do well: he was not good at loading hay on a wagon, or at building a stack, and he never learned to manage a team of horses, or a yoke of oxen as well as his brothers, but in most of the farmwork he did his tasks well-when he could not get out of doing them!

There was one thing about John as a lad that pleased 
his father: he was always ready to hunt straying sheep and salt them on the hills. His father never knew how much he brought back besides the sheep on those rambles. As a matter of fact, John felt a keen interest in sheep, more especially sheep with a fancy strain in them; also in fancy breeds of poultry. He and Eden used to hang around Neighbour Chase's poultry-yard, their eyes completely filled with the extra large top-knots of the fowl there. Although his father did not realize it, it was that extra touch which fascinated the boys-not merely the everyday breeds-it was like a bit of poetry; it appealed to their imaginations. In later years John has said that had he not become a writer, he would probably have become a fancy-stock farmer. Eden, on a small scale, followed his boyish bent. The high-bred lords and ladies in his poultry domain were watched and tended with much the same interest and affection that his more gifted brother has bestowed upon the wild birds and other creatures of forest and field.

\section{HIS FATHER'S KINE}

Nowadays, one sometimes hears Mr. Burroughs exclaim with a sigh:

\section{"Ah, well-a-day! for the good old days When I kept my father's kine!"}

though he doubtless sighed for other reasons when keeping them.

He knew those kine as he knew the members of his family. The herd of thirty or more cows was made up mostly of Durhams and Ayrshires. The "old Sam Scudder cow" was the leader, a peaceful, well-behaved creature, slender-horned, deep-shouldered, large-uddered, whose will was law in yard and stable and field. The boys 
gave her the first place everywhere. She had her choice of standing-room when milked; was first served when the herd was foddered; was given the juiciest pumpkins, and tacitly granted the best and softest places in the field. She ruled as with the breath of her nostrils-a sniff and a threatening look, and everyone gave way to her.

There were Old Brockleface, Old Bob-tail, the Far' cow (the farrow cow), the Brindled heifer, the Dun heifer, White-foot, Lop-horn, the Muley cow, and many others of varying appearances and character. There were timid cows in the herd, awkward cows, forlorn cows, kicking cows, benevolent cows, fractious cows-each with its special character, which the boys grew to know as they knew one another. They learned to keep a sharp eye on the ring-leaders in all the mischief-the ones who jumped the fences and led the others into the corn. Then there was the butt of the herd; and there was the bully, who was always pushing, crowding and goring the others. There were gentle, soft-eyed cows with faces like a deer's-all kinds and conditions made up the Burroughs herd.

One became expert at understanding the creatures. John learned to interpret their lows-whether of hunger, of impatience, of distress, of danger, of unrest, or of frenzy. He loved to watch them grazing, or lying under the trees, chewing their cuds, or standing belly-deep in the streams. He especially loved the sight of them silhouetted against the sky at twilight, as they grazed along the level summit of the side-hill above the house. He delighted to watch them eating pumpkins or apples. In fact, John loved the cow, and found most of her ways, ways of pleasantness, her paths, paths of peace. She was, in truth, the Rural Divinity at whose shrine he bowed. 


\section{DRIVING THE COWS TO PASTURE}

It oftenest fell to John and the dog to drive the cows to and from the pasture over beyond the beechwoods, half a mile or more, and they had a good many adventures by the way.

"Co' boss! Co' boss! Co' boss!" he would stand in the bar-way and call while Cuff would run down and round them up. The cows being disposed of, he and Cuff were ready for whatever might come up. It was often a chase for a woodchuck which whistled shrilly as it took to the stone wall. Now boy and dog were sworn enemies of those bold rodents that burrowed in every hillside and made raids upon the grass and clover, and even upon the garden, and the pursuit of them was swift and deadly.

Such a yelping and a pawing as there was when the dog, baffled, saw his prey escape! but they were not to be outwitted thus. The two of them were much too much for the wretched 'chuck. John would pull down the rocky sanctuary, Cuff would seize his victim, and soon the flabby rodent would be only a lifeless, bloody, disembowelled mass, when boy and dog would march away home, glad that there was one less ugly "varmint" in the fields. He remembers one woodchuck black as jet which he got when fourteen or fifteen years old; it weighed fourteen pounds.

More peaceful pastimes, however, claimed many of the summer hours. He wandered in the beechwoods to listen to the mellow flute of the veery, or to watch the antics of that Puck of the woods, the red squirrel, as he snickered and scampered amid the trees. On frosty mornings he sometimes saw him beating the "juba" on a 
limb-a regular breakdown performance, his own squeals and snickers furnishing the applause

Sometimes in poking about the woods John discovered where the red squirrel had hoarded his small savings: not far from his nest he would tuck a butternut here, a black walnut there, in the crotches of the trees, for all the world as though he had heard the warning against putting all one's eggs into one basket. He had great respect for this shrewd rodent who always seemed to know just where to gnaw into a nut the best to expose the meat; every nut he examined showed that the frisky creature had known on which side his bread was buttered.

Loitering in the beechwoods he occasionally found in a hollow tree, the stores of the little white-footed, whitebellied mouse - a quart or more of beech nuts, every nut shelled as clean as a whistle!

When going along the road with the cows he often saw the junco, or slate-coloured snow-bird, dart from a low bank in the roadside, her white petticoat fluttering as she flew. On searching the bank, there under its brink, cunningly concealed, was the nest of dry grass and moss, with its lining of finer grass and hair, and its greenish-white eggs, each with a wreath of brownish spots at the larger end.

Oftener still when in the sheep pastures he would see the modest little vesper sparrow (th? grass finch) in its dress of mottled brown, skulking in the stubble. The bird would start up at his approach, run along a few yards before him, then, flitting a pace or two, again alight upon the ground, only to start up as he came near-luring him on and on, the two white quills showing in its tail during flight. He loved this bird of the stony pastures, and at dusk often wandered out on the hills alone where, sitting 
on his Boyhood Rock, he listened to its tender strain. Little poet of the pastures! its three long, silvery notes, followed by low trills and quavers subtly expressed to him that peaceful scene-the brown stubble, the quiet herds, and the warm twilight among the hills. The bird builds on the ground in the open with no protection except, perhaps, a thistle or a yarrow to guard its door. John used to amuse himself by stealing upon it, clapping his hat over the nest, peering under at the little prisoner, and sometimes taking it in his hand when, after stilling its alarm, he would let it go-a practice that was doubtless more fun for the boy than comfortable for the bird.

\section{YOKING UP THE OXEN}

Oxen were the only horses the earliest settlers had, ar.d even in John's time old Brock and Bright, his father's oxen, figured prominently in the farm life; but in the pioneer days those patient, hulking animals were real heroes; they hauled the farmer and his belongings from one dwelling-place to another, over rough trails through the woods; they broke the first soil for the settlers; they never balked at the tasks required of them; they could live where moose and deer could live, browsing on birch and lindens until their owners could raise a crop of hay.

Brock and Bright were great handsome, sweet-breathed creatures with long, glistening, wide-spreading horns. It was often John's task to yoke them up before he was big enough to guide them about.

Going into the stall, untying Brock, and leading him out by the horns, John would take down the heavy, birchen-wood yoke, remove the key, and pulling out one of the bows, lift the end of the yoke up on his shoulder, and from 


\section{8}

\section{JOHN BURROUGHS-BOY AND MAN}

there on to the shoulder of Brock, the off ox. Then putting the ends of the bow up through the holes in the yoke, he fastened them with the key. Lifting the other end of the yoke, he would then call to the nigh ox, "Come, Bright!" and Bright would walk in and be yoked up also; in went the key, and the job was done.

\section{BOYS AND BEES}

John and Eden were keen for spying out the bumblebees and digging them out of their nests. Of course they got stung, but they expected that. They learned to distinguish three kinds of bumblebees - the red-waisted bees, the yellow-banded ones, and the white- or cream-banded ones. The first kind built on the ground, or in the braces of barns, and from them the boys got masses of comb as big as their fists. The cells of the comb are not hexagonal, like those of honey bees, but round sacs stuck together. The yellow-banded often took possession of a meadow mouse's nest. The vicious white-banded ones chased the boys out of the meadow, settled in their hair, got up their trouser legs, and gave John and Eden many a savage thrust for their interference. The boys found swatters whittled out of shingles helpful in their combats with the bees.

Once John succeeded in collecting two pounds of bumblebee honey. He squeezed it out of the comb, securing a good-sized bottleful, a great rarity. Hiding it in the attic away from the other boys, the Honey-Gatherer tiptoed up there at rare intervals to taste sparingly of the precious store. 


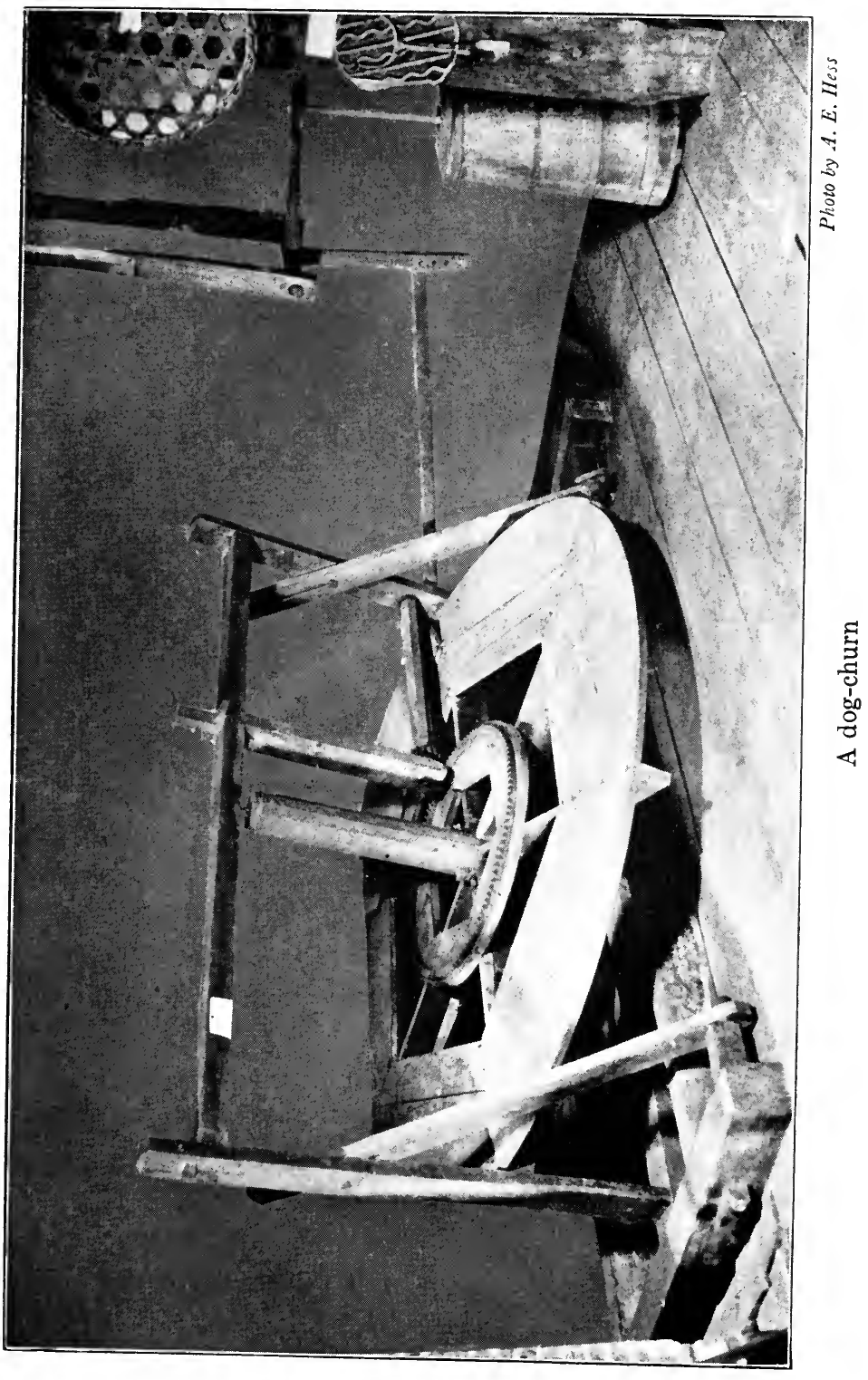




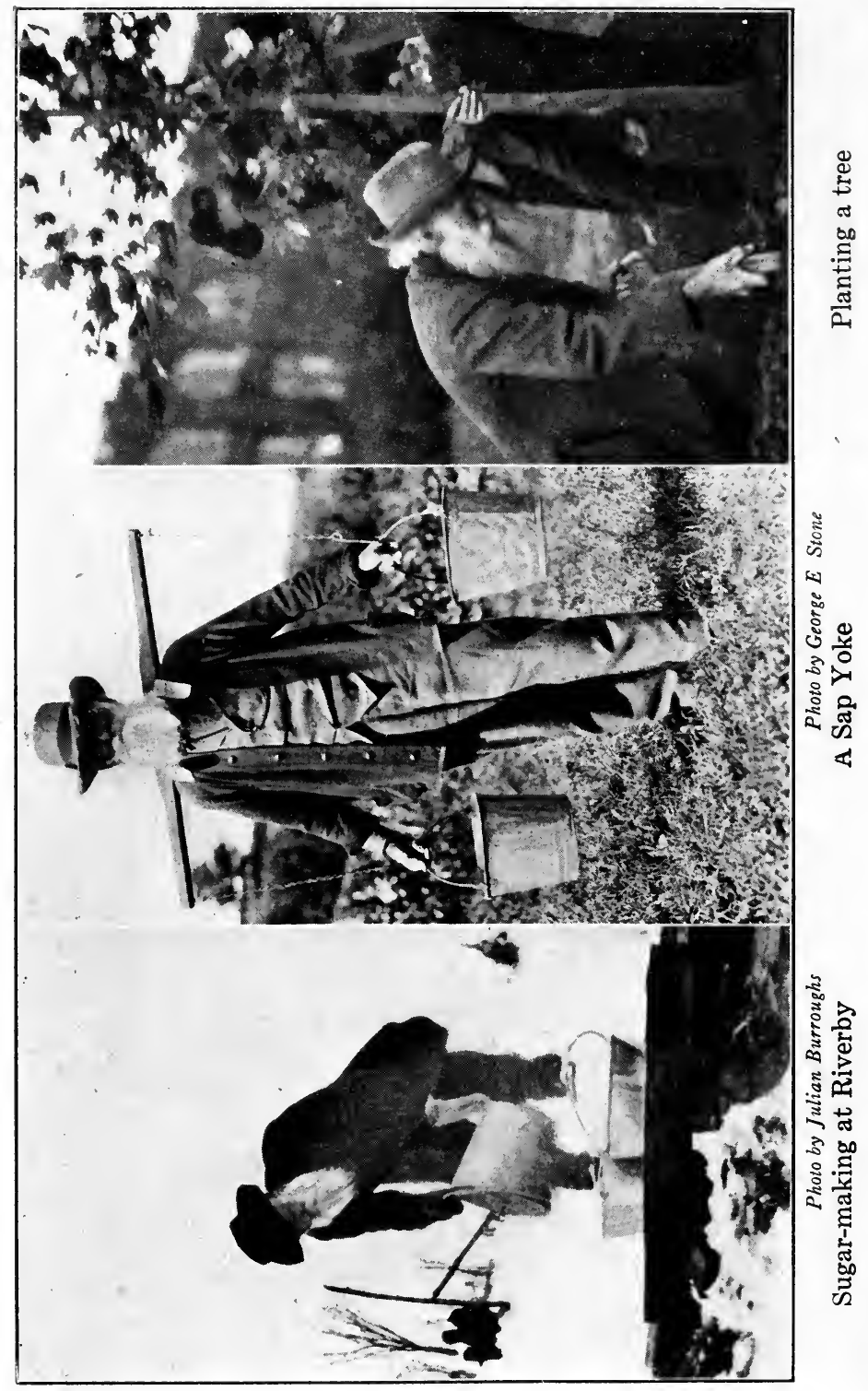




\section{HOEING BEANS}

It was bad enough to hoe beans when they had to do it at home, but when their father would send Curtis and John across lots to Noah Woolheitzer's to hoe his beans, it was a chore that did not set well. They never lingered over the job, and were at no great pains to do it so well that their services would be sought again. Having ideas of their own as to the propriety of their being impressed into old Noah's service in that way, they adopted a unique method of hoeing his beans: On coming to a fine-looking hill, regarding it long and admiringly, they decided that that hill needed no hoeing; and on coming to a poor-looking hill, they decided that that was not worth the hoeingit would be a waste of time; and so, putting nearly all the hills in one or the other' of these classes, they got along with very little hoeing of beans, and were soon ready to go home, making leisurely pauses along the trout brooks in the valley, chuckling, while lingering there, as to how expeditiously they had hoed Noah's beans.

\section{SUGAR-MAKING}

Maple sugar-making was a chore that was not a chore, but a joyous pastime. April days were a delight to the Burroughs boys, sugar-making atoned for all their hardships-it covered a multitude of chores. Even the preparation for the work in the "bush" was eagerly made with something of the zest the angler feels when, as the trout season draws near, he gets out his tackle and sorts his hooks and flies. The night before the tree-tapping the boys sharpened the old basswood spiles and made some new ones, and bright and early in the morning loaded the 
big sled with the hogsheads, kettles, pans and spiles, Brock and Bright hauling them to the boiling place under the maples. While Farmer Burroughs and Hiram cut the gashes in the trees and drove in the spiles, Curtis, Eden, and John put the pans in place on the sunny side of the trees, and soon were listening to the musical dripping in the pans. The bees smell the sap and hover near; sugarloving bugs settle on the spiles; squirrels come to sip it; the cattle and sheep, unless watched, drink it eagerly, the silly sheep being so fond of it, they will, unless prevented, drink enough to kill themselves. Of course the boys take frequent toll as it sparkles in the pans. Sometimes they find a little orange-eoloured salamander drowned in a bath of sap.

The boys frisked about the old "bush," almost as madly as did the calves in spring when let out into the barnyard. Everything was a fresh delight: the blue smoke rising in the crisp air, Phoebe announcing her name, Downy drumming his reveille to spring, squirrels snickering, and robins laughing and running about like happy children. John's cup of joy was filled to the brim; the pans were filled to the brim, too, on the days when it was good sap weather - when it froze at night and thawed by day, the contest between sun and frost so nearly equal as to make a kind of see-saw-the sun seeming to draw the sap up, and the frost to draw it down.

The boys cut and gathered birch and beechwood for the fire, the sound of their axes ringing through the woods; they built and tended the fire, pushing up the burnt ends, and adding fresh logs from time to time. Sometimes when John was absorbed watching the wild geese flying northward, or a chipmunk frisking along the wall, he 
would be brought back to the work in hand by hearing Hiram shout for a piece of salt pork, whereupon he would make his legs "clappit" for the house, returning soon with the pork which he would throw into the foaming sap to keep it from boiling over.

Later in the afternoon they collected the sap, storing it in hogsheads from which the supply in the cauldrons was replenished. (Nowadays much quicker results are obtained by the more extended evaporating surface of large, shallow, rectangular pans.)

The boys got so they knew the capacity of the whole two hundred trees in the "bush," just as they knew the individual cows in their father's herd. Some stood in little groups or couples. Some climbed the hill, others strayed out in the sunny fields; a file of six or more stood sentry to the woods above. Besides the rank and file of the commoner trees, there were certain favourites. One of these, at the head of the spring, lifted a gaunt bare arm above the woods; it was a resting-place for hawks and crows, and in it, every year, a flicker reared her brood. Then there were the Siamese twins with their bushy heads; and the two rough-coated brothers who stood in the forks of the wood-road embracing each other; and there was the old cream-pan tree which would run a cream-pan full while the others would be running only an ordinary pan full. Next to this, the best milcher in the lot was a shaggy, deformed tree on the edge of the field, while the poorest milcher was a short-bodied, heavy-topped tree near the run, which seldom gave more than a half gallon of sap in a season, but that sap was four times as sweet as sap from the other trees.

The cream-pan tree is gone long ago, but for many years 
its bones lay bleaching in the woods where they fell. Some of the old trees still stand like faithful friends, yielding their life-blood for the present generation, but at every visit to the old homestead in these later years, the boy that used to be notes with sadness others that have fallen, while the ranks are kept filled with many that his boyhood never knew.

On the second day's boiling they had the fun of making "jack-wax," or "lock-jaw": Boiling some of the syrup down to a waxy consistency, and dipping it out with a big spoon, they spread it on a pan of snow, and then the fun began! Armed with whittled sticks, or forks, they lifted the golden wax from the snow, twisted it round and round, and, on putting the toothsome gobs in their mouths, found their jaws pretty effectually locked for varying periods, depending on the size of the gobs.

A sap-run usually lasted about three days. The trees then had to be, as it were, wound up again. It had to come off cold before the sap would take a fresh start.

One hundred and fifty pails a day was a good day's yield from the Burroughs "sap-bush." Usually at the end of the second day's boiling, they syruped off: Carefully dipping the concentrated sweetness out into the pails, the men adjusted the sap-yokes, and, very gingerly, carried the heavy syrup down to the house in the gathering darkness, the boys going ahead with the lanterns. To stumble and spill a pail of syrup would mean spilling fifty pails of sap, and two pailfuls! - but that is a calamity that never visited any worker in the Old Home "sap-bush." The women folks strained the syrup while it was hot through an old home-spun sheet into a firkin, the next day reducing much of it to sugar over the fire, making it 
into cakes, but putting some in cans for immediate use on their buckwheat cakes. From three hundred to five hundred pounds was the average annual yield in the Burroughs "bush."

As the early bird catches the worm, so the early boy, boiling the first run of sap, reaped the shining coins. When the sap first began to stir, before the buds swelled, or the grass greened in the meadow hollows, John, needing funds of his own, anticipated the general tapping in the bush, and gathered annually a little harvest from scattered trees along the sunny borders of the woods. The bees, knowing that the sap was mounting, were on hand for the first run also, and boy and bees worked diligently.

Carrying the sap to the house, John boiled it down in a deep kettle on the kitchen stove (for by that time the fireplace was not used except as a place to pile stove-wood in) much to the annoyance of his mother. Even when he did not let it boil over (which seldom happened), it was a nuisance to have him pottering about. He took great pains with it, reducing it about twelve times. After allowing it to settle for half a day, clearing it by pouring in a little milk, he ran it into small, greased, patty-pans, making little white cakes, pure as wax, and with a delicacy of flavour that only sugar from the first run can have.

Every spring when he appeared in the village with his little basket of white sugar-cakes, his customers hailed him eagerly. No one else made such white sugar, or got it to market so early. The money he earned from this industry looked bigger than any he has ever had since. One season he earned twelve silver quarters that way, and, carrying them in his pockets for weeks, jingled them in the faces of his envious school-fellows, at intervals feasting 
his own eyes upon them. With some of that money he bought a little double-barrelled shot-gun. If the truth must be told it wasn't much of a gun-one barrel was bigger than the other, and one was not straight; sometimes it would go off, and sometimes it wouldn't, but it was a prized possession just the same.

One spring Curtis, deciding to compete with John in his early sugar-making, tapped some trees and proceeded to gather sap also. John, preferring a monopoly, proposed after one day's run to buy him out, so one morning offered him four cents for that day's sap. Curtis, always weather-wise, quickly closed the deal; but alas! that day the trees were on a strike; the sap wouldn't run. "It made a big hole in my reserve," said John; "I almost suspended specie payment."

One spring just after John had got his sugar made, a little sweetheart from the village, his Lowland Mary, came up to the farm to spend the day. He was very glad to have a sugar-cake to offer her, and stood by in bashful delight as she devoured it, but when she did not stop there, but ate more, and yet more, of his little cakes, he looked on ruefully, fearing his entire store would thus disappear; and he wanted that season's yield to bring him enough to buy an algebra!

What did the young Sap-gatherer of ten or twelve think and dream about in those far-off years under the maples while tending the kettles? Sometimes he beguiled the time by fancying himself going forth into the world as a young man, and acquiring great wealth, then returning to the old homestead in a splendid equipage, astonishing family and friends by his style and liberality. As he stood before the fire of the great arch and looked forth upon the 
homely familiar scenes, he pictured the look on his mother's face, the comments of his father, the envious glances of his school-fellows. We shall see later on how his dreams turned out.

\section{FISHING WITH GRANTHER}

About the most fun in summer was when Granther Kelly would come over the mountain from Red Kill to spend a few days. Some of these times he went fishing alone, but generally took John with him; when they saw him slip out into the garden without saying anything, taking along the hoe to dig for worms, they knew he was going alone; but on other days, when he said, "Johnny, get the bait," the lad knew he was to go along. "We'll go and get a powerful string of fish, Johnny," Granther would add, and the boy would hustle and get the worms or the grasshoppers. Then, reaching down his beech-pole, with creel slung on shoulder, Granther would start off, the boy close at his heels. (Their fish-lines, home-made, were of braided horse hair.)

How briskly the old man steps off! John has hard work to keep up with him! If they take a piece of rye bread and butter in their pockets, as a rule, John has his eaten long before he reaches the brook. They were usually gone three or four hours and 'most always came back with a "powerful" catch, and powerful appetites as well.

How coyly the old man throws in his hook! He knows just where the trout hide. How nicely he measures the distance, how dexterously he avoids the overhanging limbs!

"If the trout were not eager," John says, "Granther humoured them by seeming to steal by them; if playful, he 
matched their mood; if frank, he met them half-way. You see he baited his hook with his heart, so the fish had to bite!"

Sometimes Granther was magnanimous and surrendered the rod to the lad for a period all too brief, but fishing with Granther usually meant just tagging along, letting Granther have the most of the fun. Still he would not have missed it for anything.

The last time the two cronies went together, Granther was past eighty, but spry as a cricket. They went down in the Hemlocks that day and got a good catch. On the way back, stopping at a stone wall to rest, the old man, without knowing it, sat on the boy's hand as it lay on the top of the wall. It hurt, but John sat beside him motionless until he was ready to get up and walk on.

When Granther no longer went with him John used to go alone. His first solitary trouting was down in the Hemlocks, but he just went on the edge of the deep, dark woods, dropping his line in the first pool he came to, and standing where he could still look . back upon the sunlit fields. He felt no desire to penetrate alone into the gloom and mystery of those woods. The trout he took from that pool were big and black, but the shadows beyond were still blacker. Little by little, however, on each excursion, he pushed a little deeper into the woods, so that, after a year or two, he not only penetrated them, but also went on to the pastures and woods still farther away. Yet the fishing he liked best was in the meadow brooks with the gay buttercups and marsh marigolds around him, and bobolinks singing overhead. That was where he fished when he could get only a few hours off; when he had half a day, the Hemlocks was by far the favourite stamping- 
ground; but on the rare real holidays, with a whole day at his disposal, he went through meadows and pastures and beechen woods, three or more miles from home, to Montgomery Hollow. If the trout fever raged too fiercely, when no holidays were forthcoming, John was forced to play hookey, the good "catch" he usually had so pleasing his father that he escaped "catching it" on reaching home.

"Father was very fond of trout," he says nowadays, "and when they came on the table, always selected my biggest ones for himself. Well, I'm glad he did, but I was not glad, then."

He has always had the true angler's ardour; could never possess his soul in patience after getting within sight of the brook, but always had to run the rest of the way; and until he could make a few casts and perhaps get a fish or two, could never calm down enough to arrange his tackle properly.

I once went fishing with him and his brother over in Montgomery Hollow when both men were past threescore years. As we neared the stream, Mr. Burroughs began to fidiget:

"Isn't it about time to get out, Curtis?"

"Not yet, John, not yet."

We drive on. Presently he suggests, more pointedly, "Curtis, I think this would be a good place to stop." But Curtis thinks we better drive on still further before going down to the stream, and the eager angler is on pins and needles at the delay. Finally, asking no more questions, nor standing upon the order of his going, he jumps from the wagon and plunges down to the mountain stream as though drawn there by a powerful magnet, as indeed he 
98 JOHN BURROUGHS-BOY AND MAN

was. Well may he say that trout streams gurgled around the roots of his ancestral tree. "It looks as though I should never be too old to go a-fishing," he said somewhat apologetically the summer of his eighty-third year while eagerly getting his tackle ready for his June trouting in the Neversink. 


\section{CHAPTER VII \\ MORE CHORES AND PASTIMES}

Does it seem as though John's chores would never end? If it does to you, how must it have seemed to John? But luckily the pastimes were pretty well sandwiched in between the chores, and the more chores there were, the more he had to exert his ingenuity to wrest some fun out of them. Necessary evils, they certainly were, but trust a boy to endure such evils with some degree of comfort, not to say pleasure, since they could not actually be cured!

There was a deep pool below the grist-mill down in Hardscrabble creek where, of a warm May-day, the farm hands would drive the sheep for their annual bath, preparatory to the shearing. John helped only with the driving, the rest was work for men. Once down in that deep cool gorge by the waterfall, they dragged the victims from the huddled frightened herd on the rocks and doused and rinsed them one by one, in spite of their objections, John looking on somewhat ruefully, his sympathies always with the bleating sheep. As the work progressed, he clambered about on the rocks in a general tour of inspection. Every year he found a phœbe's mossy nest with its five or six white eggs, cunningly placed under the grey ledges, within easy reach of his hand, yet safe from minks and skunks, and well-protected from the storms.

The shearing of the sheep was usually done in June. Bringing the wayward creatures from the fields, the boys 
shut them up in the barn where the farm hands ruthlessly divested them of their woolly coats. Poor, protesting, struggling creatures! their shorn hides presented many a bleeding jab after these tussles. As fast as they were sheared and released by the boys, they went bleating up on the mountain again, their lambs and their tails behind them.

The wool was taken to the fulling-mill over in Meeker's Hollow, where it was carded or combed on a wire brush, made up into rolls, and then spun into yarn by the womenfolks, on the big spinning-wheel.

The yarn was dyed in a primitive way with chamberlye and indigo. The skeins, previously wound with strings, were thrown into the dye-tub where they lay for weeks, after which, on being wrung out and the strings removed, they presented the variegated blue and white appearance of the yarn then so commonly used.

A familiar sound of John's boyhood was that crescendo and diminuendo of his mother's spinning-wheel $\overline{Z-z-z-z-r h}$ ! $Z \overline{z-z-z-z-r h !}$ as his mother would walk up to the wheel and retreat, while spinning the yarn.

Coverlids and coats were made from that wool, and yarn for their stockings, mittens, wristlets, and comforts. Overcoats were not common, but the long knit comforts that went around the necks, crossing the chests, and around the waists, kept them good and warm.

\section{FLAX-GATHERING AND WEAVING}

John's father grew the flax and his mother spun it into thread and wove it into linen for their sheets, towels, shirts, and summer trousers. When we buy a yard of 
linen at a shop to-day we little think what slow, laborious work went into its making; this was especially true in those days of crude processes and primitive ways.

When the flax was ripe in the fall the boys pulled it, laying it on the ground to rot. When gathered into the barn, it was broken with a crackle-a machine for breaking up the woody parts, but not the fibre; it was like a glass rod encased in a cloth, the rod would be shattered, but the cloth left intact.

The next step, to swingle it, or to get out the woody fibre, was done by means of an upright board and a swingling-knife. The farmer would throw great handfuls of the flax over the edge of the board, striking it again and again with the swingle-a wooden implement about two feet long, shaped something like a sword, with one edge thinner than the other. The shives, or small particles of the brittle, woody stalks, would drop down, and, in due time, the flax be comparatively freed from them. But before the flax could be used, it had to be hetchelled, or combed out on a board set full of sharp teeth. Although it was a combing process, instead of running the comb through the hair, the hair was in this case run through the comb till it was clean; the pieces, probably twenty inches long, were like strands of silky hair.

In the hetchelling process great wads of tow-the shorter and coarser pieces of flax-were combed out. From this the boys made twine for bag-strings, to tie up the corn, oats, and rye. They claimed the surplus tow themselves, making of it a glorious bonfire down in the meadows in the early autumn evenings.

Next came the quilling, or winding the thread on the distaff, and from there on the spools, after which the 


\section{2 JOHN BURROUGHS-BOY AND MAN}

thread was woven into cloth on the loom. The boys made the spools by pushing out the pith from pieces of elder. Even when quite a little fellow John used to sit on a low stool and help his mother with the quilling. When the thread was on the spools, and the spools were in the shuttle, his mother would stand and throw the shuttle back and forth, while weaving the cloth.

The cloth was of a greyish hue, and, as some of the shives always remained in, in spite of the hetchelling, the new shirts and towels were pretty harsh, or "hash," as they used to say, so that breaking in a flax-made shirt, and wiping on a new towel were among the rough experiences of John's boyhood which have left a smarting recollection behind. It was like wiping on a brier bushthat home-made towel. Well that it did not scratch out both his eyes, for he has made very good use of those organs, has even taught some of the rest of us why we have two eyes in our heads. After each washing, the shirts would bleach a little, and when about worn out, were nearly white. Those shirts and trousers were tough and strong. If a boy fell out of a tree catching by his trousers on the way down, he would hang wherever caught, until released.

\section{SALTING THE YOUNG CATTLE}

Sunday mornings John's father sent him up on the sidehill toward Old Clump with a pail of coarse salt for the sheep and young cattle, a chore about which he never murmured. It was a job that could be indefinitely prolonged, and there was always much to see by the way. The prairie horned larks flitted before him with their shuffling, jingling, lisping calls; goldfinches soared above in 
their billowy flight, calling gaily, "Here we go, here we go!" the vesper sparrow kept companionably near; the indigo bunting sang incessantly from the trees along the fence borders; butterflies sailed around him; and grasshoppers danced in a merry maze wherever he started them up as he climbed.

Then there were springs to be visited-the one high up toward the mountain-top, under the ledges, and others in the pastures, these, especially, often needing his attention. Whenever he found one fouled with leaves and trodden by cattle he cleared it out, on his return finding the water clear and cool. The salting of the cattle itself was a never-failing delight. The knowing creatures, seeming to divine when it was Sunday, were waiting for him at their "lick," instead of rambling here, there, and everywhere. How they would follow him about, eagerly licking up the salt as he scattered it on the smooth stones! He loved to watch them smack their lips over it, and gnaw the sward for the last bit. It was almost as good fun as to watch them eat pumpkins or apples, which always made his mouth water.

Sometimes a cow would be missing from the herd pastured below the beechwoods. This meant that the boys had to go on a hunt for her-another agreeable task. They never had the wondrous adventure, though, that Granther once had in that vicinity, years before: One night while wandering around in search of the lost Io, he heard something in the brush, and lo! out in his path there stepped a bear! The bear did not get him, nor did he get the bear. Bruin ran away even more scared than was Granther. 


\section{BURNING STUMPS}

When the early settlers had come in that region, they had to cut the birch, beech, maple, and basswood to browse their cattle, there being, of course, no hay until they could clear the land, raise and rake in the rye, sow grass seed, and thus secure a crop of hay. As a result of their tree-cutting, numerous stumps dotted the cleared land, and in John's boyhood a part of the spring work for boys was the burning of those stumps.

As they would come down to breakfast in the early April mornings, their father would say:

"John, you and Eden go up to the clover meadow to-day and burn stumps."

This was a lark. Building a huge fire, they would work with a will the long forenoon through, working merrily day after day. The sparks burnt holes in their clothes, burning them more and more each day, till after several days at the job, they were almost past wearing. One day Eden's new hat got afire and a big hole was burned in it. That wasn't so much fun when they got back to the house.

Sometimes they found a stump with a bluebird's nest in it. They always spared that stump. Approaching it stealthily, and clapping his hat over the nest, John could usually catch the bird in his hand. Then, on lifting his hat, he would free the little prisoner, which would rush out with a glad cry. Granther Kelly used to do the same thing when a boy. Once, when putting his hand in a stump to feel for bluebirds, he felt something peculiar, something "comical," he used to say, and on withdrawing his hand hastily, out came the head and neck of a black snake! $\mathrm{He}$ ran, and the snake ran after him. It had almost 
reached him when a ploughman struck the snake with his ox-whip. Safe to say John never questioned this story when Granther told it, but nowadays he would doubtless say that Granther, whose imagination was most lively, must have imagined that part about the snake chasing him.

\section{STONE WALLS}

In that mountainous Catskill region the meadows and pastures were divided, as to-day, by long lines of stone walls which give the land a characteristic and pleasing checker-board appearance. These dark, rugged boundary lines frame the fields, inclose the woods, creep up the steep hills, and descend to the valley bottoms. John used to listen with interest when Uncle John Kelly on his visits from Pennsylvania told how free the land in their state was from stones; how their fences had to be made of rails. A rail or a board fence was unheard of around Roxbury. The boy wondered why there was such a difference in the two regions, but there was no one to explain to him that it was the great Ice-sheet that was responsible for all that back-breaking work of picking up stones, of which he had so much as a boy. Those grooves he used to see on the rocks, high up on the hilly pastures and which he regarded so curiously - he had no inkling that they had been made by the glaciers passing over them, transporting the rocks and gravel, and leaving those tell-tale marks. Nor did he know a thing about that other mysterious force, Erosion, which had had so much to do with smoothing and rounding the familiar broad-backed hills, and scooping out the wide valleys of his native landscape.

The farmers, in that country so abundantly supplied with stone, turned their hindrances into helps, by "mak- 
ing the fields grow their own fences." A stone wall is a veritable sermon in stones, and a long, tiresome one at that. So thought John, and so thought his brothers while being pressed into the service of prying up rocks, and picking up stones.

Every spring John's father built about fifty rods of new wall, and sometimes as much more in the fall. The boys groaned in spirit when these times came round.

Stones of all sizes and shapes, big and little, round and square, thick and thin, smooth stones, jagged stones, stones of no shape at all-all was grist that came to the mill of the stone-layer. All were piled on the stone-boat drawn by Brock and Bright, and hauled to the place where the wall was to be laid. They were first thrown along in a windrow-an irregular, chaotic line of stone from which the new wall slowly grew. Hiram, as has been said, was a good stone-layer; his enduring monuments stretch in never-ending line all over the Burroughs farm to-day; but the other boys, not entrusted with such skilled work as that, were chiefly helpful in gathering the raw material. They liked to watch the building of the wall, and to be on hand when blasting was to be done. The stone-layer makes his wall broad and deep at the bottom and firm and smooth on the top, making one side, the face side, much smoother than the other. Two rods a day was a good day's work, but a certain man who worked for John's father had a record of laying eight rods in one day!

\section{BARN-RAISINGS}

The boys rejoiced when there was a barn-raising on hand. A "raising" meant just the putting up of the frame, the weather boards and the roof being added later. First 
the foundation was prepared and the sleepers and sills put in-work taking several days - then the neighbours came from miles around to help with the raising.

Carrying the beams and posts and joists to their places on the platform, they put together the first "bent," fastening it with oak pins. Then fifteen or twenty men with pike-poles ranged in line abreast of the bent, awaited the sharp commands of the "boss" as he steadied and guided the corner post:

"Take holt, boys!" "Now set her up!" "Up with her!" "Up she goes!"

They hoist it shoulder-high, then each man with pikepole braced awaits further orders:

"Altogether, boys!" "Heave her up!" "He-o-he! he-o-he!" shouts the boss at the top of his voice, every man doing his utmost.

There was one man at the barn-raisings, Rice Bouton, who always took John's eye; his strength was prodigious; his nimbleness and alertness were remarkable. The first one on the bent, catching a pin and putting it in place, he would walk the high beams fearlessly with the great beetle in his hand, and putting the pins in the holes would drive them in, as much at home in that perilous position as a squirrel on a limb.

\section{A MOVING}

When John was thirteen years old his father decided to move the old house away (the house in which John was born) and build a new one on the old site. It was indeed an exciting time. The house with all its contents was to be transplanted to the orchard, where they were to continue to live while the new house was building. These days were brimful of interest. When Farmer Burroughs 
bid his neighbours to his Moving-Bee, twenty farmers came, each bringing his yoke of oxen. The preparations for the moving, however, had taken several days: Two long smooth beech trees were cut down and hewn for the runners, and many green beechwood poles for skids. Prying up the house, they placed it on the runners, with the skids beneath. How queer the old house looked loosed from her mooring! She was setting out on her first journey pretty late in life.

With the heavy log chains, each link as big as a man's thumb, they chained her to the runners, and then hitched fast the twenty yoke of oxen and steers, in two long lines, one at each runner. Men and boys, stationed with levers, awaited orders.

\section{"Ready!" \\ "Go!"}

Slowly the two long lines of oxen straighten; the great creatures settle into their bows; the chains around the runners tighten; the strain continues-but look! something has given way! A chain has broken! There's a delay while it is mended. Presently the work is resumed. Again the command:

"Go!"

Gads are flourished. Shouting lustily, the men urge on their teams, laying their "buds" on harder and harder. The excitement grows intense. The oxen bend to their work; their eyes bulge; their nostrils widen; the commands from the drivers rise to a discordant Babel. The old house creaks; she groans as if alive; she starts; she moves; and, once in motion, moves away to the orchard "as nimbly as a boy on a hand-sled," while the onlookers cheer mightily. 


\section{HAY-MAKING}

Haying in John's time, lacking modern machinery, was a thirty days' war, or more, and had something of the urge and excitement of battle. The work required many "hands" who came from near and far. Good mowers would quit their regular work, and, with scythe over shoulder, go about from farm to farm to help with the haying. Wages for this work were extra good, and the men were expected to work extra hard. They had a certain pride about it, too; the boys soon caught the fever - hay fever, shall we say?-and were eager to do their stunts as well as the men.

The hay-makers were usually in the meadows working an hour or two before breakfast. With a stroke level and sure, they cut a wide swath, leaving no spears standing. There is a rigid etiquette of the hay field which John learned in his teens: One must not take another's swath; each has his turn as leader; it is not good hay-manners to mow too close to your neighbour, unless driven by the man behind. When one mower tries to put another through, that other, not to be out-done, follows close, and a heated race is on.

What a picturesque sight of a midsummer afternoon as the mowers move amid the ripening grain! and when, toward sundown, the smooth slopes, shaven and shorn, are dotted with haycocks! The great stack is built in the meadow, a man atop of it taking the forkfuls of hay from the pitchers below. But when the hay is mowed away in the loft, the picturesqueness is as hard to find as a needle in a haystack -it is just a hot, dusty, tiresome job!

John worked at spreading and raking hay long before 
he was old enough to take a turn at the mowing. But when he was fifteen or sixteen he could hold his swath against any youth of his age in any field, and even with some of the men, although on quitting for the nooning, his knees would shake under him from his sturdy efforts at keeping up with the men.

When the scythes got dull he had to turn the grindstone while Hiram ground them. At the best that was no picnic, but how he dreaded to see Uncle Ezekiel come to help with the haying! for he carried a gin bottle in his pocket, and after resorting to it a few times, mowed stones as readily as grass. The grown-up boy nowadays points to a field near Woodchuck Lodge and says, "Uncle Zeke cut the tops off all those stones in that field there, and $I$ had to turn the grindstone!"

Haying always comes in the hottest weather. Many a time John fairly panted for breath in the hay-field. When it got unbearable, if they were anywhere near the swimming-hole, he dropped his scythe and took a dip, not stopping to remove his scanty clothing which was scarcely wetter when he came out than when he went in. And Oh! the delight of those pauses in the mowing, when they would stop and draw out the jug of spring water from its place in the shade, each mower in turn putting it to his sweaty lips and taking long draughts! They knew nothing about germs in those days and, blissfully ignorant, shared and shared alike with the little brown jug under the swath.

At ten o'clock, resting under a tree, and looking out over the quivering air of the fields, they ate their snack of rye bread and butter, with perhaps a cucumber and a doughnut to top off with. Thus fortified, on they mow till twelve, when summoned by the dinner horn, all hands 
hurry to the house. Washing up at the watering-trough, and taking their turn at the roller-towel, they seat themselves unceremoniously at the long table amid much clatter, raillery and guffaws.

The women bustle in with the heaped-up dishes; the hungry men fall to and attack the food. Now and then one reaches with his long arm, pieced out by his fork, and spears a slice of bread. Generous pieces of pie, cheese, doughnuts, and other eatables go the way of all the other food, and, wiping their mouths on the backs of their hands, and shoving back their chairs, they scatter, some going out on the door-stones, others, leaning against the wall in tilted chairs, smoke or keep silent, until the "boss" gives the signal to return to the fields.

\section{THRESHING}

In the fall and winter John and his brothers threshed oats and rye on the floor of the barn that stood out in the field, called the barn on the hill.

"John, I want you and Curtis to go out and thresh five or six shocks this morning," his father would say at the breakfast table.

\section{A shock was fifteen sheaves.}

Filling their pockets with apples, the boys start out and tackle the job: Laying the sheaves down with their heads together in two long rows, they set-to with the flail-the instrument for beating grain from the sheaves. It was a straight, strong, hickory hand-staff to which hung, by means of a leathern thong, a wooden swipple, two and a half feet long, and about three inches in circumference, the swipple being the part with which the beating was done.

What a flapping and a pounding they gave those heads 


\section{JOHN BURROUGHS-BOY AND MAN}

of oats and rye! what a jolly noise it made as the flails chased each other through the air! and what fun it wasfor a little while. But the dust filled their nostrils and settled on their clothes and in their hair, and, somehow, the fun was done long before the stunt was.

When they had threshed a flooring, the straw was bound into bundles, the grain being left in a pile till enough accumulated, when it was run through the fanning-mill.

Threshing was a far more agreeable process to watch than to engage in. John delighted in watching them thresh buckwheat in the open: The men would spread the ruddy sheaves on a broad flat rock, or on a level piece of ground, and set to with a will. What a picture they made beating out the grain! and what a loud thud they made! and when there were three or four beating together, it was a continuous roll of sound. Threshers had to be very deft to keep from hitting, or being hit, with those swinging flails.

Out in the autumn sunshine it was lively and interesting work, but the dullest of drudgery in winter when, day after day, on dry cold days the boys, or, what was worse, one boy, would be sent to pound away by himself on the barn floor with the flail.

John remembers hearing of a suitor of his sister, Olly Ann, who threshed for them one fall-a man of prodigious strength who could shoulder a barrel of flour. He threshed fourteen shocks of oats in one day - an unheard-of thing! Jonathan had looked upon Olly Ann and had found her as beautiful and well-favoured as Jacob had found Rachael, and would fain impress Farmer Burroughs with his industry, and Olly Ann with his great strength, and so the four- 
teen shocks had seemed unto him but a few sheaves, for the love he had for her; but, alas! the maiden did not look with favour upon the sturdy Jonathan, and the sound of his flail was heard from the barn on the hill no more.

\section{APPLE-GATHERING}

Lives there a boy, a live boy, anywhere who does not like apples?-green apples, sour apples, crab apples, the poorest seedlings, even frozen apples-any of these will do in want of better ones, for an apple's an apple, even though there are apples and apples to the real apple connoisseur.

An apple is full of sunshine, and full of sugar-try those brown, juicy frozen ones that you find hanging on the bare trees in winter if you don't believe it. The apple is a rose when it blossoms, and a rose when it's ripe, so says the man who learned to be an expert judge of apples when a boy. He had apples in his blood and in his bones. The apple lured him, as it did Mother Eve, into forbidden regions, even into Neighbour Scudder's orchards where special favourites grew. He was invariably apple hungry when a boy.

The very sound of the apple dropping in the orchard was music to his ear; the siren winked at him with its single eye; it nodded to him from the boughs; it beckoned to him from afar; he willingly helped store it in the cellar in the fall, and fill the apple-hole in the back-yard, later in the season. On his tramps over the hills he crammed his pockets with apples: taking one out he would toy with it, rub it round and round, press it to his cheek, fumble it in his pocket, smell it, toss it in the air, roll it on the ground, and, in due time, eat it; and then he would eat another, and another, and another. 


\section{JOHN BURROUGHS-BOY AND MAN}

Apple-gathering almost ranked with sugar-making as a work that was three-quarters pastime. In the mellow October days, piling the bags and bushel baskets on the wagons, they drove over to that part of the home-farm called the Rundle Place, and gathered the fruit from both upper and lower orchards. What delightful work to sort the red and green and golden piles and fill the bags, and then the cellar bins!

Later in the season, some were put into the apple-hole. Some also went into special nests in the hay-mow where they lay and mellowed and, in dwindling numbers, awaited the frequent visits of the apple-misers who had hid them there; but if old Brindle, as sometimes happened, got her nose through the open door, she quickly smelled out the hidden hoard and made short work of it.

This is the way they made the apple-hole: Digging a shallow pit about a foot deep, and perhaps five feet in diameter, they spread in it a thick layer of rye-straw and dumped the apples in, many basketfuls, the hardiest, choicest varieties. They piled them up to as steep a peak as they could and still have them stay put.

How good they looked-the Greenings, the Spitzenburgs, the Northern Spies, the Tallman Sweets, the Swaars, the Kings, the Russets, the Belle-flowers!

Covering them all round, close and warm, in a coat of rye-straw, and spreading over this a layer of dirt so as to hide the straw, they also added, before winter set in, an overcoat of dry stable manure; the winter snows completed the covering. No frost could penetrate to the garnered fruit, and there it lay till spring, growing in grace and flavour in the darkness and silence.

As the supply in the cellar bins got low toward spring, 
the boys would attack the apple-hole. Taking a spade and an axe, they penetrated through snow and frozen earth till reaching the coat of straw, a little dingy and the worse for wear, but still serviceable; then, thrusting in their arms and mining for their favourites they drew them forth, crisp and cold, and glad to see the daylight again!

\section{CIDER-MAKING}

When the time for cider-making came round the boys sorted out the inferior apples, even the rotten and wormeaten ones, and took them over to the Gould farm in the West Settlement, where Jay Gould's father, who was the only farmer in that region owning one, had a cider-press.

The apples were first crushed in a mill. The horse, hitched to a sweep that turned the wooden cylinders, walked round and round. The crushed fruit was shovelled up to form the "cheese"-a layer of straw, a layer of apples, a layer of straw, a layer of apples, over and over, this was the "cheese." The press was then put on and screwed down, the mass yielding the amber juice that ran down a groove into a tub. Leaving it over night, they came back the next day and barrelled it up.

When the gimlet-holes were bored in the barrels for vents, the boys, armed with long straws, with bellies on barrels, lay and sucked up the delicious juice till too full for utterance. While hauling the barrels home they smacked their lips in anticipation of further delights. The contents would enliven many an autumn evening in the old kitchen!

\section{'COON-HUNTING}

Among the Snow Walkers on which the Burroughs boys kept a sharp eye were the raccoons that would come out 


\section{JOHN BURROUGHS-BOY AND MAN}

early in the spring, lean and hungry, from their dens under the rocks, so much in want of food that they even came around the barns and out-buildings.

One morning in early spring, before daylight, the boys, hearing Cuff bark vociferously, knowing what was up, quickly got.into their clothes-Wilson, Curtis, Eden, and John; and, on rushing out, found Cuff standing at the foot of an ash tree not more than thirty rods from the house. The dog was looking up into the tree and complaining sharply at the tardiness of the boys; and well he might! For there on one of the bare branches clung a big threatening 'coon!

Wilson, the boldest of the "bunch," shinned up the tree to shake the 'coon down, while Cuff bounded and barked with delight as he saw him climb. When he got within ten feet of the 'coon, seizing the branch on which it clung, he shook it long and vigorously, but to no purpose. Wilson was in greater danger of losing his hold than was the 'coon of its. Moreover, the 'coon growled and showed unmistakable signs of advancing on the enemy, causing Wilson to go down much faster than he went up.

They finally brought the rascal down with the gun, but for some moments it fought the dog fiercely, returning bite for bite, giving up the ghost only after it had been shaken unmercifully by Cuff and bitten clean through the small of its back!

"The raccoon is clear grit," says John, in rehearsing the incident. "He never shows the white feather. He is probably the most courageous of all our wild animals."

It was in the fall that cooning was such a pastime. Then the creatures were desirably fat and sweet-fleshed from their raids on the corn fields. 
One moonless October night the boys and the 'coon dog started out in search of the nocturnal thieves, stealthily creeping near the ravaged fields at the east end of the farm.

"Hunt 'em up, Cuff, hunt 'em up!" they called as they sent in the dog; and Cuff went rattling through the corn; but the 'coons escaped on the opposite side of the field, displacing a stone which rattled loudly as they made for the nearest woods.

Presently the dog struck the trail and, clattering over the wall, entered the woods. One or two short barks, then all was still, for the dog barks very little when on the trail. But when the barking became loud and continuous - a baying sound - they knew that Cuff had treed his 'coon.

Pell-mell up the hill and into the woods they rushed in the darkness, falling over logs, pitching into hollows, one losing his hat, another tearing his clothes, and all so wildly excited by Cuff's mad barking that they stopped, breathless, only on reaching the tree.

Making a light they try to shine his eyes, but the 'coon is either too well hidden, or too knowing to look at the light, and, as the tree is too large to fell, their only course is to sit at its base and wait till light enough to see their quarry. Hiram and Curtis go home, but Wilson and John stick it out till morning, when Wilson brings the captive down with ready skill, Cuff frankly and emphatically expressing his approval when Wilson slings the 'coon's warm body over his shoulder. As the sleepy boys and triumphant dog march home, their mouths water at the thought of the roast 'coon that is soon coming to them. 


\section{JOHN BURROUGHS-BOY AND MAN}

\section{HOUND AND FOX}

One of the winter joys in the Catskills was the wild cry of the fox on the mountains. John used to go out and stand in front of the house on still moonlight nights in winter and listen to that weird call, uttered at intervals, almost seeming to see the wily creature up there on the shoulder of Old Clump, sitting on the snow in his furs. Sometimes as he listened he would hear the voice of another fox answering amid the ghostly winter hills.

The long, trumpet-like baying of the hound on the mountain was music to John's ears. Sometimes it could be heard for a mile or more; now it comes near, now recedes, or is lost entirely, as the dog pushes on or descends into a gully; again it comes nearer and is loud and sharp, only to be lost yet again as the hound moves farther and farther away. The fox seems to enjoy the chase as much as does the hound which he lures on from spur to spur of the mountain. Confident of his superior fleetness, he even seems to wait for the dog; he sits down and listens; he stops for a mouse; he crosses and recrosses, and doubles on his track, apparently chuckling at thus perplexing his pursuer. But when the snow is very deep, or wet, it is the hound that laughs last, for then the fox's tail gets so bedraggled he is forced to be a quitter, and take refuge in his den. When caught, they say, a fox "looks too cut up for anything."

John used to practise for fox-hunting by aiming at pumpkins which the other boys would roll down "Steepside." One day when he thought himself skilled enough to bag Reynard, he took the old musket and followed Spot on the mountain. As the hound started on the scent, 
burying his nose in the snow, he drew a deep breath and gave a snort; the scent being but faint at first, he wagged his tail in silence; but on coming upon more convincing evidence, he let out a melodious bay and was off.

On finding the run-way of the fox, John waited there a long while, gun in hand, but, no fox appearing and becoming chilled and benumbed, he rested the butt on the ground, keeping his hand on the barrel, and waited some more. Presently something stirred. Not fifty feet away a superb red fox, a large male, his massive tail tipped with white, came into view.

So startled was the lad and so fascinated at the sight of that yellow pumpkin that was not a pumpkin, as the handsome creature came loping along, that he stood motionless, gazing in amazement and admiration while Sir Fox gracefully disappeared over a knoll!

Aroused too late to his duty as a sportsman, feeling cheap enough, and out of humour as well, John trudged off home, mentally cursing hounds and foxes generally, and himself in particular. The worst was when he told his brothers about it:

"Why didn't you shoot, you goose!" asked his brothers, and all the answer the mortified lad could think of was, "B-b-because I had my m-m-mitten on," and for years thereafter that mitten was thrust in his face.

"Did you have your mitten on, John?" Curtis would ask tauntingly if John failed in any undertaking.

\section{WILD PIGEONS}

It is about fifty years since the passenger pigeons have frequented our fields and groves, but in John's boyhood they could be seen in myriads passing over his father's 
farm. There were millions of them then because the conditions of climate and food favoured their increase. They did not tarry long in one place to tempt their enemies, but came and went like the summer clouds, not always every year, but every beech-nut year.

John used to watch their vast armies passing over, and listen to their tender, childlike calls. Sometimes the sky was actually darkened with them.

One day in early spring when they began to pour down in the beechwoods, he seized his musket, and running up the road, crept along behind the stone wall till within a few yards of the swarm of fluttering birds. The air, the woods, and the ground were blue with them; they whirled, and rushed, and fluttered, and cooed, as they moved about picking up the sprouting beechnuts. The ground seemed a yard deep with pigeons. The excited boy pointed his gun at the surging mass, then sat motionless, spell-bound -had the whole world turned to pigeons? Why did he not shoot? Still they came pouring down from the sky, and still the boy sat there waiting, his eye travelling along the gun-barrel, his whole being under a spell.

Suddenly they arose! With a rush and a roar they were gone! and then the dazed dreamer came to his senses!

There was no pigeon pot-pie that day for dinner in the Burroughs home, but one wonders whether the luckless hunter did not, after all, bag more birds that day in the beechen woods than if he had sent his deadly shot into the fluttering masses.

Pot-hunters and netters are responsible for the extermination of those beautiful birds. Though so abundant, they could not withstand the ruthlessness of the hunters. John used to hear of vast hordes of pigeons in other parts 
of the Catskills, especially in the Neversink valley; they nested in the trees over a tract many miles in extent, and there the greedy gunners thronged, making a perfect fusillade as they slaughtered them by tens of thousands.

It was the custom of the female to sit on the nest till noon, when the male would come and "spell" her; knowing this, the merciless hunters timed their attacks so as to kill them both. The birds that escaped went on with incubation as though nothing had happened, but countless nests were thus broken up. This continued for years, and then the birds began to take wider and wider range in search of food. Their last great nesting-grounds on record were certain localities in Michigan, where a fearful slaughter of them was made.

The hunters also set nets for them: After baiting them for a while, they would hide in bough shelters, with ropes running from their nets to the bough houses; thus entrapping tens of thousands. Any of our other birds might share the fate of the passenger pigeon if our game laws failed to protect each species.

Instead of protecting the birds, there were in John's boyhood some states that even protected the conscienceless hunters: Massachusetts in 1848 passed a law protecting the netters of wild pigeons, and levying a fine upon any one who frightened the birds from the nests! but in 1870 it passed a law protecting pigeons-birds which had once been sold in its streets for a cent apiece! It is said that in the town of Hartford, Michigan, in 1869, there was a daily shipment of three carloads of pigeons for forty days, and that two years later, in another town in the same state, there were marketed 15,840,999 birds! The shipping records early in the nineteenth century show that 
every great market from St. Louis to Boston received hundreds of thousands of barrels of pigeons in one season.

The last wild pigeon Mr. Burroughs ever saw was in April, 1875, and that year seems to be the time when wild pigeons were last seen in great numbers anywhere in the United States, only a few in scattered flocks having been reported as observed later. It is believed that a female wild pigeon born in 1885 , raised in captivity by the Cincinnati Zoological Society, and dying in 1914, was the last of the race.

Every little while, from various parts of the country, come reports of one or two of these birds having been seen, but on investigation they are usually found to be mourning-doves. In 1910, or thereabouts, several persons earnestly concerned in saving the wild pigeons, if they were indeed not extinct (Mr. Burroughs among the number), offered rewards amounting to over two thousand dollars for an undisturbed nest of wild pigeons anywhere in North America. Although the offer held good for two years. none of the rewards were ever claimed, many supposed "finds," on investigation, proving to be mourning-doves. The mourning-dove is about four inches shorter than the wild pigeon and seven inches less in spread of wings. It lacks the blue tint about the head and the reddish undersurface of the persecuted bird, and it never gathers in flocks for nesting purposes, though it may be seen in small flocks in winter.

Mr. Burroughs says it would be one of the gladdest hours of his life if he could again see the spring and fall migrations of the passenger pigeon. 


\section{CHAPTER VIII}

\section{THE ANTI-RENT WAR}

(1844-1845)

THERE is a picturesque and little known episode in our history - the Anti-Rent War-of sufficient importance to warrant introduction here. Occurring somewhat earlier in John's boyhood than the period we are now considering, it was waging around Roxbury and the surrounding country when John was seven and eight years of age, causing serious commotion, particularly through the counties of Delaware and Schoharie. Compared to the Great War of our day the Anti-Rent War was but a tempest in a teapot, and a very small pot at that, yet was a bitter, heartburning period for the elders, while the small boys of Roxbury were tremendously concerned about it, there being spectacular features at times highly entertaining.

The troubles arose over the leased land held by the settlers, for which they had long paid rent unprotestingly, till, coming to regard the rental as an injustice, rebellion arose. According to grants under King George III, great tracts of land in certain sections of New York State had long been held by patroons under various patents, such as the Hardenburgh, the Bradt, the Franklin patents. The Hardenburgh patent, granted in 1708 , and the one about which centred the anti-rent trouble in Delaware County, had given to one man and his heirs forever nearly two million acres. Long before the Revolutionary 


\section{JOHN BURROUGHS-BOY AND MAN}

War disputes had arisen as to the boundaries of this patent, owing largely to a clause in the grant, "the main branch of the Delaware," the two branches being so nearly equal as to make it difficult to decide which was the main one. The Indians had long occupied the tract between the two branches, but in 1751 the holders of the patent had purchased the disputed tract. Thus it had come about that a portion of land on the farm where John Burroughs was born (as well as many other farms roundabout) had been yielded to the Hardenburgh heirs by certain Red Men before the War of the Revolution. Some of the Indians who put their marks to the contract bore the following names: Sandervatheverander, Anough, Hendrickhokeau, Swathekeen, Suppau, and Monau.*

After the War of the Revolution, the poverty of the settlers, and the hard times generally, prevented them from redeeming the land upon which they had settled, and which in most cases they had vastly improved; and as abuses on the part of the patroons crept in, the settlers chafed more and more under their bondage. There were durable leases, redemption leases, three-year leases, and yearly leases in the various contracts. A durable lease was for "as long as grass grows and water flows," the settler and his heirs to retain possession forever, to use and improve, on the payment of the stipulated annual rental. The terms were usually seven years' rent free; or a yearly rent of a shilling an acre; or one or more fat fowls; or a certain number of bushels of corn or of wheat to the acre, or its equivalent in money. Some leases also required of the tenant one day's attendance and service at the landlord's

\footnotetext{
* For this and several other facts in this chapter I am indebted to Jay Gould's History of Delawore County.
} 
manor house-a curious survival of the feudal system in a country but just emerged from a successful war for liberty.

Although many of those old leases were worn to tatters, yet they were strong enough to hold the broad acres to which they related, according to their terms. They were uniformly sustained by the courts: One decision went so far as to hold that non-payment of rent for sixty-three years afforded no sufficient presumption of release from the contract as against the old lease, produced and read at trial.

Chafing under conditions which they regarded as unjust, and which they were powerless to alter, the farmers grew to hate the landlords, and to hate their agents who exacted the hereditary tribute, a feeling which descended from fathers to children, unto the third and fourth generations. "How we used to hate the sight of old Kiested who came around to collect the rent," I have heard Mr. Burroughs say.

In 1844 the worm began to turn. As most of the tenants were law-abiding citizens, they at first held mass meetings to discuss the injustices from which they suffered, and to devise means for drafting new laws. They formed an Equal Rights Association, and published a paper, The Voice of the People. The upshot of it all was, they pronounced the long-held claims of the lords of the manor fictitious; held that they were therefore justified in defying them; and that the intolerable state of affairs must cease.

Those tenants with heavy loads of back rent were the most bitter, but more prosperous farmers also sympathized with the rebellious attitude. Landlords and tenants clashed more and more, and thus arose the anti-rent war. Soon, what had started as a righteous indignation 
degenerated into a lawless, ill-advised attempt at reformation.

Certain members of the Association banded together, masked and disguised as Indians. They formed tribes, appointed chiefs, and held secret meetings, whence they filed out, a motley band, with pranks and war-whoops and a lot of tomfoolery, at the same time seriously bent on creating sufficient public sentiment to overthrow existing authority. The sensational methods adopted by "the Indians" naturally attracted the young and adventurous, and the malcontents-those most likely to carry their pranks to illegitimate lengths.

With painted sheepskins stretched over their heads for masks, and holes cut in for eyes, nose and mouth; with cows' tails tied on behind; sometimes with horns of animals fastened on their foreheads, and feathers in their headgear, the "Indians" looked diabolical enough: Some wore blouses of striped cloth, with fantastic calico trousers; some were encased in meal bags; some decked out in red flannel pantaloons. They met in barns and out-ofthe-way places to scheme how to gain their ends. They tormented the up-renters who approved of the rentals, stirred up revolt in the lukewarm, and attempted to intimidate the sheriff, or his deputy, whenever he tried to eject a tenant, or to sell his stock to collect the rent.

The up-renters, as a rule, lived on land not covered by the patents, and had scant sympathy for the down-renters. The father of John Burroughs was a down-renter, a certain strip of the farm, as has been said, being leased land from the Hardenburgh patent. Jay Gould's father was an up-renter.

This burning question divided the school as well as the 
neighbourhood. There was many a skirmish, and some pitched battles were fought over this grievous question at the little West Settlement school. The up-renter boys going down the road ranged themselves against the downrenter boys going up the road, stoning them as they went by. The down-renters taunted the up-renters with being Tories. The up-renters scorned and spurned their accusers. Even in their snow forts and snowball battles the two factions were pitted against each other.

John remembers once sneaking around a barn where a meeting of the "Indians" was in progress, curious to know what went on at those mysterious gatherings. He had watched the "Indians" steal into the barn from various directions, and, creeping up cautiously, was just about to peep through a crack, when an "Indian" punched him in the face with a straw, which caused him to scamper home.

After one of their indignation meetings the anti-renters sent forth a decree that henceforth the blowing of a farmer's dinner horn should be the signal for the "Indians" to gather at said farm. In this way the farmer could notify the others when the sheriff was about to sell his cows, or otherwise extort the rent. They warned everybody not to blow their horns unless they wished their houses straightway filled with "Indians." John Gould, sturdy and independent, had no notion of letting the anti-renters thus infringe on his rights. He declared he would blow his horn when he wanted to, and, defying the decree, sent forth a rousing blast at mid-day, as usual. In short order, from all directions, hurrying across the fields, came the "Indians." They filled the house and yard. They swarmed about John Gould. They danced and yelled. They smeared him with tar, and, then ripping open a pillow, plastered him 
with feathers; then, after a few more pranks, giving their war-whoops, disappeared.

The down-renter boys did some crowing over the uprenter boys at school the day after this escapade. Other so-called Tory families were similarly served, and the feeling waxed stronger and stronger.

Many farmers who did not actually join the ranks of the anti-renters sympathized with, and abetted them. The father of John Burroughs was one of these. One day, on hearing that the posse was coming over the hill, and having a somewhat guilty conscience, Farmer Burroughs grew frightened, and, running across the fields to an uncle's, hid under the bed, but left his feet sticking out; and there they found him! Years after he would tell this joke on himself, enjoying it as much as any one.

How excited John used to get on seeing the deputysheriff and his posse of thirty or forty horsemen come cantering along, two by two, on their way to some recalcitrant farmer's house! Sometimes they rushed through the country at breakneck speed, the deputy-sheriff flourishing his sword, the men armed with muskets and horsepistols.

One eventful day John went with his father and mother to an anti-rent meeting over in Red Kill, where an attempt was made to elect Members of Assembly who would presumably frame laws to relieve the oppression. There was much blowing of horns, and a great pow-wow among the grotesque "Indians" who came across the fields in single file, and in small bands, from all directions, thus contributing to the success of a meeting that would otherwise have been a very stupid one, John being the judge. They sang a song composed by a woman over in 
"Batahvy"- a rousing appeal, to the tune of "Bannockburn":

\author{
Raise the gate and standard high, \\ Let the feudal chart pass by, \\ Meet them and their power defy \\ On our native soil!
}

From time to time incautious anti-renters were captured and put in jail, mostly for trying to prevent the sheriff from serving papers on the farmers. John remembers a thrilling time when, after such an event, a blustering farmer, Birch Hammond from Red Kill, came over the hills to their house carrying a horse-pistol, and declaring that he was going over to Delhi to get his half-brother, Zeke Kelly, out of jail. He would show them what was what! He wasn't to be trifled with! They would deliver Zeke to him or he would know the reason why! Flourishing his pistol, he stalked about the kitchen making his threats. Little John, watching him in admiration, believed implicitly that he would get Zeke out of jail, believed also that a great hero was in their midst. How mighty he looked looming large in the candle-light!

John looked on, awestruck, as the man laid his horsepistol on the mantelpiece at bedtime with final declarations of what he was going to do.

The lad's dreams that night were of the fierce encounter of the morrow, but as a day and a night, and part of another day, went by, and Hammond showed no signs of terminating his visit, and said no more about going to the relief of Zeke, and the rusty pistol lay undisturbed on the mantelpiece, the boy's illusions about the doughty farmer gradually dwindled away.

Still, these were stirring times, and nearly every day 
tales were rehearsed of the activities of the "Indians" in first one quarter, then another. Early in 1845 the legislature passed an act making it a misdemeanor for anyone to disguise himself as an "Indian," and proclaimed it a duty for the officials to arrest all such. This caused more caution, but also more hard feeling.

In consequence, the first man in Roxbury to feel the hand of the law was one 'Ras Squires, who as a Chief was known as Big Thunder, charges being preferred against him for tarring and feathering an up-renter, and for purloining the sheriff's papers. The posse and deputy-sheriff visited his house at midnight to arrest him. They found him hidden between the ticks of a bed on which his wife and mother were (supposedly) sleeping. Big Thunder's voice resounded in the little cell of the jail at Delhi after that for a season, and the "Indians" became more circumspect, only to break out some weeks later in some new defiance.

The anti-rent trouble culminated in that locality in the town of Andes: Deputy-sheriff Steele had advertised the stock of Moses Earle for sale, in payment for sixty-four dollars back rent. Indignation rose high among the antirenters, and the "Indians" collected to the number of two hundred in the nearby woods, where they made a hideous racket with horns and drums and war-whoops.

As the sheriff and the agent of the landlord, who had gone there to bid on the property, began to round up the cattle, the "Indians" gathered from the woods to thwart them. Threatening talk and gestures passed back and forth. Trying to reason with the rioters, the agent told them he was there in accordance with existing laws, while they were outlaws; he declared his intention of bidding on 
the stock, whereupon they told him if he did, he would go home in a wagon, feet foremost. As he persisted in trying to drive the stock near the bars, the "Indians" massed themselves close to the cattle and swore to prevent the sale.

Just then, Steele, and Edgerton the constable, and his posse, appearing on the scene, rode up to the bars. More altercations. It is said that Steele, to arm himself for the fray, had indulged too freely in liquor, and became uncommonly insolent; but it is also said that a pail of whiskey passed along the line of the "Indians." When Steele, with great bravado, charged over the fence in their midst, waving his sword, and the constable called to all citizens to unite in preserving peace, a cry of "Shoot the horses!" arose from the infuriated "Indians," and the volley fell! The horses of both Steele and Edgerton were shot. Steele fell bleeding to the ground. Consternation reigned. Evidently no one had actually intended shooting any man, and at sight of what they had done, the "Indians" fled in a panic. Steele, suffering horribly, was carried into the house, and died in a few hours.

The whole country was roused. Who had fired that fatal shot? As several had fired, it was difficult to fix the crime. Suspicion centred most strongly upon one of the chiefs (Warren Scudder) and alarmed, he fled the country, the infuriated posse on his track. He outwitted them by concealing himself in a peddler's cart where he lay curled up amongst the dry goods and Yankee notions. The peddler stopped from house to house with his wares, while the pursuing posse flew by miles in advance, scouring the country for their prey. The fugitive went down the Mississippi, working on plantations there for several years, after which he returned and took up his old life undisturbed. 
Before the excitement died down, however, many a head that had worn its crown of feathers lay uneasy, for the aroused citizens demanded protection for their officials, and punishment of the guilty. Crops were left unharvested, many "Indians" fleeing the country, and many who remained behind were in terror of being apprehended and imprisoned. The Governor (Silas Wright) declared the county in a state of insurrection. His proclamation denounced the lawless methods to which the "Indians" had resorted, but urged law-abiding citizens to set about to right the injustice in a legal way. Following this proclamation, light infantry came from Unadilla and other towns, and soon several hundred men were under arms. Arrests became frequent; the jail was soon filled, and two log-jails were erected to accommodate the overflow. Although two men were convicted of murder and sentenced to be hanged, and some were sentenced to prison for varying terms, in the course of a few months these sentences were commuted by the Governor with the approval, it is said, of the community.

In time the excitement died down-a sort of peace without victory; the farmers ceased their rebellion, and the legislature modified the law to some slight extent; and though rancor and heart-burning continued long in the opposed factions, the tomahawk and the hatchet were buried.

About two years after the shooting of deputy-sheriff Steele, when John Burroughs and his brothers were digging stone in a field one day, they came upon a buried relic of the anti-renters who, it seems, had buried more than the hatchet. There was a hideous mask of stained leather, with horns on the forehead, and with the coarse hair of 
animals glued on for scalp locks and a beard. They recognized it as having belonged to a left-handed neighbour, Keator, who had been to their house with the band of "Indians," when on their scouting parties. On such escapades the "Indians" would solemnly file into a farmer's kitchen and demand food and drink-"Me want cider," "Indian want apple," and the like. On being served, this left-handed man had been easily "spotted" by the boys, for he peeled his apples and took his glass of cider in his left hand. Afraid to be found with the "Indian" toggery in his possession after the fatal shooting at Andes, the Benjamite had doubtless hid his mask in that field under the stones.

Even to-day some of the farmers in Delaware County continue to pay rent to the holders of the patents. Certain strips of the Burroughs farm are still levied on to the amount of twenty-five dollars a year, this rent being paid by the man who, as a boy, was so often thrilled by the doings of the belligerent anti-renters. 


\section{CHAPTER IX}

\section{SCHOOL DAYS}

AFTER two summers at the old stone jug, as they called the first school that John attended, the Burroughs youngsters went to the West Settlement school, John going there in the summer till he was eleven or twelve, when, being old enough to help on the farm in earnest, his schooling was confined to winters. His last winter there was in his seventeenth year.

It was a long way to school now-up a hill, down a smooth rolling meadow, through a piece of woods, through more meadow and pasture land, then across a creek in the valley - a mile and a half from home. Never too long a walk in summer, but trudging through the snows those long winters was a tough experience. With caps pulled down over forehead and ears, muffled in comforters, they battled with wind and snow, often wading through drifts waist-high, the snow getting in at their boot-tops, later to melt and trickle down and add to their discomfort during the thawing-out process around the school-house stove. $\mathrm{Oh}$ ! the misery of that process, from the time their numb hands and feet began to tingle on through the forenoon when the burning and itching drove them frantic! and drove the teacher frantic, too, with the uneasy wriggling and shuffling induced by their chilblains!

The footpaths they followed, especially in summer, furnished a good deal of natural history for an observing boy: 
There were trout in the valley stream. They used to feel for them under the banks; by slipping their hands along, they could often get good big fellows, grabbing them under the gills. Squirrels scampered along the fences, and in winter skunks and 'coons sometimes sallied forth from the woods and crossed their path. In the May woods they gathered the early wild flowers, and sought the crisp, aromatic, crinkle-root to eat with their bread and butter at noon, though John usually ate his before reaching school. They carried their lunches in a little red and white splint basket-rye bread and butter, apple-pie (which in winter was often frozen on reaching school), cookies and apples.

The spring that supplied the drinking water was "quite a piece" up the hill, and John's desire to make himself useful took the form of coaxing for this daily task. It was surprising how often he found that spring roiled by a frog or a muskrat, necessitating a long wait for it to settle; surprising, too, how painfully neat he was, requesting permission at very short intervals to go out and wash his slate!

The noon-mark cut in the window-sill of the old schoolhouse was a point of daily interest to the boys. Watching when the sun got there, they grew exceedingly restive if the teacher did not dismiss school on the instant.

Sometimes the boys went down to Stratton Falls for their nooning, bathing in the creek under the rocks. It was a long way off, and occasionally they decided that since they would be tardy anyhow, they might as well stay all the afternoon and get material for slate pencils. Loitering there in the deep gorge worn in the shaly rocks, they hunted out the soft green streaks in the red sandstone, first testing them on their teeth to make sure they 


\section{6 JOHN BURROUGHS-BOY AND MAN}

would not scratch their slates! They saved these up till winter, whittling them out into pencils in the long evenings before the fire. Some boys became very deft at pencil-making. It was quite a trick to get a good-sized piece, nicely whittled, without breaking it, and a boy who could do it extra well was the envy of the whole school. The best pencils were used as barter. John always envied one boy an especially fine long pencil with its shining-copper gun-cap. He was never able to swap his pocket treasures for it, and when his hair was white with age he confessed that he had seldom coveted anything in life as he did that slate pencil of Hi Bouton's. There was another thing he remembers coveting - the hair of a boy named John Shout. The Shout boy, who was his senior by several years, spent half his time in school curling his hair under so that it formed a beautiful glossy roll in the neck; he also had a peculiar well-trained lock in front by his cowlick, which was John's despair.

"How I envied that boy his hair! I tried to make mine curl under, but it wouldn't; I was always imitative, and I guess I am still-in certain things," he confesses.

\section{He says further of these days:}

John Shout went away to study and came back a doctor. One summer when he came home-I was in the garden weeding onions-I remember how nimbly he stepped as he went by our house. Later, when practising there, for some reason he shot at poor old Cuff, putting a bullet-hole in his hip, and one day after that, as he was riding past with his saddle-bags, Cuff, who was the kindest dog in the world, ran out and nearly pulled him off his horse. He never forgave him the injury-a good illustration of the associative memory of the dog.

It was in this school that John took his first writinglessons, simple lessons consisting of straight lines and pothooks turned upside down. 
I was between six and seven, I think. Liberty Cator and I were learning at the same time. I can see yet how he used to squeeze the quill. I did not make quite such hard work of it. When we got so we could make the pot-hooks, we would put two together to make an $n$, and three to make an $m$. We learned coarse hand (capitals) before we tried fine hand.

We took our goose-quills to school and the teacher made our pensthat's what a pen-knife was for, you know; he also sharpened them for us when they needed it. "Please, sir, will you mend my pen?" was a request the teacher must have found very tiresome.

Hiram made our ink-wells by casting them from molten lead. We carried them home in our pockets so the ink wouldn't freeze. Our ink, sometimes black, and sometimes purple, was bought at the village store-no, it was earlier than my time that they used poke-berry juice for ink. Hiram would take a cylindrical piece of dozy wood and hollow it out, shaping it like the cavity of an ink-well; then, tying a piece of moistened fool's cap paper around it, he poured in the lead, later digging out the wood. For the cork he whittled a pine stick to fit.

Winter sports consisted chiefly of snow fights, coasting down the hill-meadows on the crust, and fishing for suckers through the ice. They had only such sleds as they made. Sometimes they slid on barrel-staves fastened together, and sometimes on the rude sled with ash runners that Hiram made - a sled with steel runners being a luxury of which they never even dreamed.

There being no ice very near, John did not learn to skate when a boy; in fact, he never had on a pair of skates till, when five and twenty, he learned to skate on the Hudson. But winter fishing was a sport not to be sneezed at. John ran away one day and went fishing in the Pepacton with four men who, happening by the school-house at recess, asked him to come along.

Cutting holes in the ice midway of the long still reach of the river, and at either end, the men stationed John at the end of the reach with a long pole. He felt very 


\section{JOHN BURROUGHS-BOY AND MAN}

important at this. Two of the men, starting at the end of the pool, hammered the ice with axes as they came down while the others, lying with faces close to the water, watched at the holes and hooked up the fish which shot along underneath. It was John's stunt to thrust the pole under the ice and keep the water so agitated as to turn the school of fish back as it came down, and he did it well. At each drive, for a few minutes, the fish were snatched up through the holes at a lively rate, till the ice round about was a mass of suckers, with now and then a trout.

Gathering up the fish the men carried them, a bushel basket-full, over to the inn at Shacksville, proceeding to divide them. As there were four men in the party, they began throwing out the fish in four equal piles. John stood there looking mournfully on when one of the men, chancing to glance up and see the lad's expression, called out, "Why, here's Johnny-we must give him some"; so each in turn threw him a sucker from his pile till he had a very respectable one of his own. Hurrying home, he trusted to the fine mess of fish to atone for his truancy.

The summer games they played at school were chiefly ball, I Spy, Head-All, Den, and Throwing Knives-the boy who threw the farthest getting the choice of knives. The boys made their own balls, ravelling out old stocking legs, winding them tight, and covering them with leather which they sewed with a waxed-end, if they could get one from the cobbler in the village. Their bats were handmade, crude affairs. Head-All was a game much like Pom-Pom-Pull-Away of to-day. Den was one in which the boy who was "It" led off, fleeing like a deer across the fields, the others taking after him for a specified goal. 
At recess the boys used to propound riddles to one another. Here is one that John remembers:

Grandfather fimiduddle

Danced in a mud puddle,

In red-top boots and a green fur hat.

Guess all your life-time,

You can't guess that.

The answer is the masculine to one of our domestic fowl. (A drake.)

There were perhaps two dozen books in the library of the West Settlement school, and John used to take them out regularly, reading them over and over. They were mostly books of travel or of adventure. Murphy, the Indian Killer he read again and again, thrilled by the heroism of that intrepid fighter of Red men and Tories. The Life of Washington, the authorship of which is unknown to him, also made a lasting impression upon him when he was probably not more than eight years of age. He recalls how one Sunday morning when he and his brother Hiram and a cousin were playing through the house, carrying this book in his hand, he would stop every little while and read aloud a certain passage which moved him strangely. Its eloquence almost lifted him out of himself, although the older boys seemed indifferent to it. In this connection he recalls other exalted emotional states which occasionally came to him a few years later, particularly one of a June morning when, walking on the top of a stone wall across the summit of a hill, a piece of a root shaped like a pistol in his hand, he felt an unwonted joy. Walking along the toppling stones, flourishing his rude plaything, he called and shouted and exulted, drunk with the wild joy of living. Life was amazingly beautiful at that moment, and his soul sparkled and flashed in the sunlight. 
His sensitiveness to the eloquence of the Washington book might lead us to expect a more critical taste for other literature than we find borne out by the facts. Truth compels the statement that at the age of ten he delighted in a book of Negro jingles containing such lines as these:

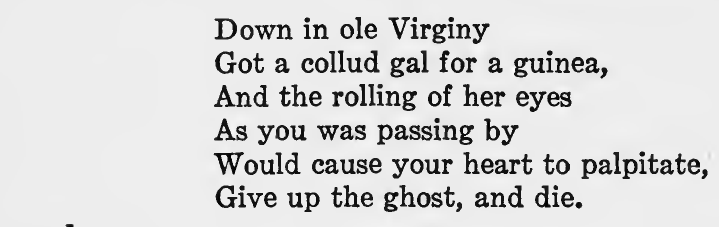

and

Ole Miss Tucker, she is big and fat,

An' she's as black as my ole hat,

Her eyes stick out, an' her nose sticks in,

$A n$ ' her under lip hangs over her chin.

Uncle Tom's Cabin was published when John was a lad of fifteen, and although he must have heard much talk of a book which made the stir it did, then and later, still he never read it, and, what is more, doesn't remember ever having had a copy in his hands.

At about the same time (1852) Kossuth came to the United States to stir up sympathy for the Hungarians ground down by the Austrians. Although John remembers often hearing Kossuth's name, the only association he had with it was with the large black Kossuth hats which came into vogue at that time - current history topics evidently were not made much of in the West Settlement school.

Some scenes of those school days are vividly stamped on John's memory: One of his teachers, Bill Allaben, struck Dave Smith on the head, and Sandy, Dave's elder brother, spoke up, saying, "My father don't want 
you to hit us on the head," whereupon the angry teacher laid the whip on Sandy, belabouring him more and more as he failed to flinch, striking him so hard that the whip made a dent in the desk where it hit the edge. "But Sandy was game," said grown-up John, admiringly, recalling his spunk-"his Scotch was up-the man was contemptible -we ought to have put him out-doors!"

Hiram once "sassed back" another teacher (Graves), an inefficient man who was having a hard time with the grammar lesson. Now Hiram was a "cracker-jack" at parsing though he could not write a grammatical sentence to save his life. In fact, all the boys were blissfully ignorant of there being any connection between parsing and correct speech. Seeing the teacher evidently in doubt about a point, Hiram ventured a suggestion.

"I don't want any of your help," snapped the teacher.

"Well, you need some help," retorted Hiram; and the evident truth of the retort doubtless saved the froward pupil a flogging.

One day this same teacher, on detecting a boy eating apples behind his Olney's Geography, peremptorily called him to the middle of the floor:

"I saw you this time," he triumphed as the boy approached.

"Saw me what?" indistinctly articulated the boy.

"Bite that apple."

"No, sir."

"Open your mouth!"

The boy obeyed, and from its depths the teacher extracted a piece of apple.

"Didn't know it was there," announced the culprit, unabashed. 


\section{Commenting further on his school-fellows, Mr. Bur- roughs, in his eighty-third year, said:}

There are only three or four of us left, so far as I know, and very few of us have made any great record for ourselves.

There was George $\mathrm{H}$. Cator, my seat-mate, the old man you have seen wheeling the mail bags on a wheel-barrow from the station-he died a year or so ago-George didn't like work any better than I didhe led a desultory kind of life, sitting round taverns a good deal. George gave far more promise of amounting to something than I did. I can remember how much fun he always made at the apple-cuts, while I would sit there mute and stupid, filled with envy.

There were the Scudder boys and girls, two families of them. Milton was a bright, well-mannered fellow-studied law, went West, and died there in early manhood, and Peace, his sister, died long ago. Rube Scudder, the boy who walked with me to Lexington that time to spend the Fourth, was a jolly, freckle-faced lad with sandy hair. He was a good fiddler-I've told you how he could dance the "juba" [and he gets up and shows how he did it] to the envy of all the other boys. He became a school teacher-died in Beaverkill in 1870. It was his father that shot the sheriff in the Anti-rent trouble, and his grandfather, old Deacon Scudder, whose apples we used to steal.

The Smith boys and girls lived where Tommy Smith lives now; they were canny Scots. Some of the children were born in Scotland. The boys wore little Scotch caps to school. I remember they sometimes brought cold pancakes for luncheon, which caused some of the boys to sneer, but now any of them could buy and sell those boys. They were all thrifty, and have been prosperous farmers. Most of them flew far and wide like thistle-down. John and Will and Sandy, who went West, have accumulated a good deal. I had a letter from Sandy a few weeks ago; he was my favourite. It was Sandy I have spoken of in one of my books who, when a child, riding through that wild mountain pass-the Long Woods-asked: "Mither, is there a God here?"

Andrew Corbin and Jay Gould sat behind George and me in school. Andrew became a merchant, first in Roxbury, then in Bloomville, where he died years ago, and Jay - everybody knows that Jay became a multimillionaire.

Jay had several sisters-Betty, Annie, Polly and Sally. Betty was a stern girl with the Gould pride, who carried a stiff upper lip, like her father. I remember once when a phrenologist came to town she and I went to have our heads examined. He told me I was going to become 
a rich man! I believed in phrenology then. Sally was much like Betty. Annie was a beautiful girl, modest and gentle and conscientious. I shall never forget her sweet eyes; and Polly, ah! Polly was the flower of the family - a very sweet girl-I remember once at noon in the old schoolhouse when we were all playing about-I a boy of fourteen had an end of one of the seats up on my head-Polly stood there looking on, and suddenly rushed up and kissed me. She was two or three years older: I suppose I flushed and was too bashful and awkward to kiss her, as I probably wanted to do-sweet Polly Gould! I'm sure she was just as winsome as Leigh Hunt's "Jenny":

\section{Polly kissed me!}

Time, you thief! who love to get

Sweets into your list, put that in!

Say I'm weary, say I'm sad,

Say that health and wealth have missed me,

Say I'm growing old, but add-

Polly kissed me!

"Jay seems to have been the only one of the West Settlement boys to make his mark in the world."

"Except J. B.," I remind him.

"Well, yes, J. B. has made some marks-on paper; some of them may last-I hope so-but he has spoiled a good deal of paper and ink in his time."

So it was in this little old school-house that John Burroughs and Jay Gould were school-fellows seventy-odd years ago. Here they played and wrestled together, swapped slate pencils, traded knives and marbles, helped each other out of scrapes, and into them, and went home with each other nights; or, rather, John sometimes went home with Jay, not Jay with John.

"He was too proud to stay at our house."

When asked what Jay had to be proud of, he answered, "Well, the Goulds were very prosperous, and naturally stiff-necked; and they lived in a little better style than the other farmers." 


\section{JOHN BURROUGHS-BOY AND MAN}

Both these boys left school early, going out into the world with little education beyond that of the district school. Each in his way attained national and international fame, though doubtless neither they nor their school-fellows dreamed that either would ever be heard from outside of Roxbury.

Jay used to snicker when John stammered in the reading-class, which cut John so keenly that he often stayed out after recess till the class was dismissed, the indulgent teacher ignoring his absence.

John was stockier than Jay and a trifle taller, and could, as a rule, throw Jay when they wrestled unless Jay, ignoring the rules of the game, broke his hold.

"Now, Jay, you broke your holt - that wa'nt fair," protested John; but the victor, having adopted rules of his own, would answer convincingly, "But I'm on top, ain't I?"

One day when required to write a composition, John had copied something from an almanac and passed it off as original. Detecting the theft, the teacher sentenced him to stay after school, unless he should hand in a certain number of lines before the close of school. Taking pity on him, Jay wrote some doggerel on his slate and, nudging John, passed it under the desk for him to copy. John, neither too conscientious nor too critical to accept it, copied it off on his own slate and shamelessly turned it in as his, going Scot-free when school was out.

These are the lines with which Jay Gould came to the rescue of John Burroughs: 
Time is flying past,

Night is coming fast,

I, minus two, as you all know,

But what is more

I must hand o'er

Twelve lines by night

Or stay and write.

Just eight I've got,

But you know that's not

Enough lacking four;

But to have twelve

It wants no more.

Note the economy, the thriftiness, and the sharp bargain that this Shylock of a poet drove with the inexorable teacher, even when dealing for another! The genius of the financier showed even then. The required number of lines was furnished, but-could lines be shorter? The law was fulfilled to the letter, nor wrote he more, nor less, than just twelve lines!

A few years later, when Jay Gould was hard up, John, buying two old books of him,- - a German grammar and a work on geology - helped him out of a tight place, paying him eighty cents. Jay had then left school and was living in the village over his father's store and tin-shop, and working at a map of Delaware County. So the future financier helped the future writer with his pen, and the future writer helped the future financier with his coins! John once helped out Jay with eighty cents, but Jay left eighty million dollars when he died!

Jay used to coax me to go home with him nights. I remember staying there once when they lived in the village, when I had to leave very early in the morning. It was Election Day, and as I went out on the silent village square, I heard a voice bawl out: "Hear ye! hear ye! hear ye! the polls of this election are now open!" It was Burhans, the town 
clerk, opening Election, but there wasn't a blessed soul around to hear but me.

No, I never saw Jay after the Roxbury days-not to speak with him. He surveyed for the map after leaving school, then wrote a history of Delaware County, then got into his various speculations. Our paths lay far apart.

I have never followed his career very closely.

I saw him once in New York, on Fifth Avenue, many years laterrecognized his gait at once. And once he came in the Treasury Department in Washington where I was working. The Deputy Comptroller brought some officers from the Commercial Bank of New York in there, requesting me to show them the vault, and Jay was among them. He did not recognize me, though I knew him instantly. I showed them the vault, but did not make myself known to Jay-Yes, one would think I would have-there's a queer streak in me, I guess.

When Jay Gould helped him out by supplying those lines, it is clear that John's desire to write had not yet come to him; in fact, at that period he usually got out of the required task in one way and another. He never could write to order, anyhow; the spirit has to move him first, and the spirit never moved for those Friday afternoon compositions. Why, even one of his teachers, Walter Eliot, with whom John was a favourite, took pity on the lad one day and wrote a composition for him, letting him copy it surreptitiously, so as to maintain discipline. It was something about Napoleon. All that he now remembers of it is that it had a high-sounding expression about the bridge of Lodi. He remembers, however, his sheepish feeling while standing there and reading the composition he had not written. It cured him of wanting to repeat the experience.

He developed rather early a keen interest in words, and always tried to find the meaning of new ones he heard. A woman calling at the house one day, on seeing him trying 
to make a coloured drawing, exclaimed, "Why, what taste that boy has!"

John pricked up his ears- "Taste! then there is a kind of taste besides that of things to eat!" He was copying a chromo of General Winfield Scott, in which the hero stood by his horse and a nearby cannon. This was presumably shortly after the Mexican War when Farmer Burroughs, his admiration aroused in the hero of Lundy's Lane and Chapultepec, had bought the chromo.

Another addition to John's vocabulary at this time came about thus: One day while watching some men at work on the road, he saw one unearth a queer looking stone and, examining it interestedly, say, "What have we here-some antiquities!" "Antiquities!" John asked what that meant, and in the explanation a new world was opened up to him.

As he grew older he became more and more keen about words. He liked to say over certain phrases met in books. Certain words themselves captivated him. The words "Encyclopædia Britannica," heard at a lecture in the village, fascinated him-they made such a fine mouthful! $\mathrm{He}$ copied in a little book high-sounding sentences that appealed to him-the future writer was just beginning to handle curiously his tools.

(Chancing to come upon the name and a wood-cut of John Burroughs the other day while looking up something in the Encyclopædia Britannica, I showed him the picture -an atrocious one, however. He made some uncomplimentary remark about "the old codger" to which I replied, "But think how astounded that West Settlement lad would have been had anyone told him he would sometime see his name and picture, good or poor, in the Encyclopædia Britannica!") 
John's father was frequently annoyed by his requests for things his brothers never mentioned, especially books. He could not understand this.

"Why should he want things the others don't want?" he complainingly asked the lad's mother, and she could only reply by saying vaguely, "Why, you know he is different from the others"; and it was reason enough for her. When John came home from school one day all on fire with enthusiasm for an algebra, his father, whose education never took him even through the back part of the arithmetic, inquired impatiently, "An algebra! What is an algebra?"

John tried to explain, but hesitated and stammered and, scenting failure, gave it up before his father shouted his refusal. The mother plead for the lad in vain. Next day, on starting for the village, John returned to the charge, but with no better success. With that emphatic No! ringing in his ears he set off, but on nearing the Pennyroyal Rock at the top of the hill, heard his father shouting that he might have his algebra-his mother had gained the point. His "dander" being up by that time, however, he decided he would wait and earn his own algebra, which he did by his early sugar-making, of which we have read. Richer than all the Goulds in later years was that farmboy when some of that precious self-earned money secured his algebra. He had suddenly come into possession of two treasures-the book itself, and the comfortable realization that within himself lay the means to meet his growing desire for books. Later he earned a coveted rhetoric in the same way.

A curiosity which his brothers did not share led him, at thirteen, to attend a lecture in the village in which the 
starting of a new Academy in Roxbury was agitated. He was the only lad among a small group of men and women. Urging the matter eloquently, the speaker told what a boon it would be to the girls and boys of the vicinity"boys like that one there," he said, pointing to John; and John dropped his head and blushed, but went home fired with the thought of the new Academy, and with the visions of learning evoked by the speaker's words.

A wave of excitement was sweeping over the United States while John, a boy of twelve, was still attending the West Settlement school-the Gold Fever that raged in 1849 and later.

Talk concerning that wonderful Eldorado in the newly acquired state of California, kept the West Settlement boys pretty well stirred up. Someone in California had picked up a piece of gold along the American river the year before while excavating for a mill-race. The news had spread like wild fire, first to Mexico and the Sandwich Islands, as the Hawaiian islands were then called, and later to the East Atlantic States. Daily the boys heard tales of the Forty-niners - of the mad rush they were making to the mountains of California to dig for gold. Thousands of men left the East during that year, lured by tales of the washings along the western rivers, yielding the diggers fifteen and twenty dollars a day, while those who struck rich "placers" were said to make even five thousand dollars a day! Such rich streaks, however, were quickly worked out, and the unlucky ones who rushed there later often met with the cruellest disillusionment. Frenzied by fabulous tales, the prospectors would often leave a promising locality, journeying far away in quest of better "diggings," only to meet discouragement and failure, some- 
times starvation and death. These tales, however, were not the ones that reached the East-not until some time later; only the glowing tales were circulated, fanning the flame in every little village and town.

Excitement among the schoolboys rose to the highest pitch when three Roxbury fellows, between twenty-five and thirty years old, caught the fever, and the citizens of the village made up a purse to help them off. They went on ships to the Isthmus of Panama, and, making their way across, partly on foot, took their chances with hosts of other gold-crazed adventurers who fought desperately for passage on the overburdened ships sailing up the Pacific Coast.

But, alas! none of those Roxbury youths made their "pile." After the first glowing letters, news of them practically ceased. Whatever adventures they had were unknown to their anxious townsmen. One died in California, in the Fraser River rush, it is thought; the fate of another was always a mystery; and the third (Kennedy) returned home, a poor man, ultimately, however, making his fortune by foisting on a credulous public the much advertised panacea-Dr. Kennedy's Favourite Remedy!

Another historic wave of excitement, this time of a religious nature, swept over the country the year after the Gold Fever started. It was caused by a third prophecy of the Millerites, or Adventists, heralding the Second Coming of Christ. This sect had set previous dates in 1843 and 1844, and the faithful had duly provided themselves with ascension robes preparatory to the end of the world. When, in 1850, a third prophecy was made, the expectant believers, undaunted, again made ready to welcome the chariot of the Lord.

There was considerable commotion around Roxbury as 
the appointed time drew near. One day at school when a terrific thunder storm arose, the big girls, greatly excited, regarded that as a sure sign and portent of the approaching end.

As the forked lightning played across the heavens, and crash after crash of thunder broke over their heads, as ominous clouds darkened the sky, and the rain in heavy sheets completely obliterated the mountains on the opposite side of the valley, the terror-stricken girls trembled and paled and wept. They feared each crash would prove the last before the final trump should sound. Some huddled in frightened silence, others screamed and groaned, a few prayed, as peal after peal crashed over the little school-house. And when they saw a huge black cloud come driving across the sky from the East, they shrieked, "There it comes!" and buried their heads in their arms, in abject terror awaiting the end!

John had heard, unmoved, this talk about the end of the world, but when he saw the terror among the girls, and among some of the boys as well, combined with the unusual electric display, he began to be a little imbued with belief in the prophecy. He grew solemnly observant as that ominous cloud came driving toward them. If, indeed, this was to be the end of the world, he wanted to see what it was like! But the cloud was no chariot-it held only water. The lightning ceased, the thunder died away, and as the valley was again flooded with sunlight, the girls grew calm. Then and there the observant lad, putting that enlightening experience in his mental pipe, smoked it, reducing it to what it was worth-ashes. "And that's the cheese of it!" was, in the Roxbury vernacular, his sensible conclusion. 
The only Movies in John's school-days were, for example, those of actual life, of cattle and sheep wending their way down the steep paths in the pastures, of oxen drawing the stone-boat, goaded on by the farm-boy's gad as he shouted his gee's and haw's; of trout darting in the meadow-brooks; of hosts of wild pigeons darkening the skies, wheeling and alighting in the nearby woods-tame affairs compared to the Movies that thrill the boys and girls of to-day! So when John craved excitement he went 'cross lots down to the village to a lecture! and not a lecture arranged to interest the young either, for of such there were none; but he eagerly accepted whatever offered, glad of anything on which to feed his growing hunger for intellectual things. During that last term at the district school, he attended two consecutive lectures in the village, in which the speaker aimed to prove that the soul was not immortal. "Immortal fiddlesticks!" thought Hiram and the other boys, as they poked fun at John for taking those long lonely walks over the hills in the dark, to listen to such fol-de-rol. But something drew him there. Listening eagerly, taking notes of the Biblical passages cited by the lecturer in support of his views, he looked these up on reaching home. (It was with a peculiar interest that I recently examined those pencilled citations made in a little notebook by that eager, thoughtful lad so long ago.) He was by that time beginning to look on both sides of a question, beginning to test things, and to do a little real thinking on his own account, though in a vague, untutored way.

As we have seen, John's desire for knowledge and hunger for books became acute that last year at the district school. He had, in fact, for two years previous, longed for something more than the humble little school offered. During 
the summer of his fifteenth year, as he had watched the village Academy nearing completion, he had pictured himself going 'cross lots in the fall to join the first pupils to enter its walls. But his father had effectually dashed those hopes before school opened. John coaxed and his mother pleaded in vain, his father, however, giving a half promise that if he stuck to the fall work, he might go to the Academy for the winter term. He kept his part of the bargain, but his father did not keep his. When winter came it looked like a piece of nonsense to Farmer Burroughs-the school in the West Settlement was "good enough for anybody." So there John continued to go, but how yearningly he regarded the boys who attended the Academy! They seemed to move in another sphere.

The following summer his aspirations mounted still higher-he wanted to go away to school. Dave and Sandy Smith had come back from the Franklin Institute with glowing accounts of the life there, and Dick Van Dyke from Harpersfield with equally glowing tales of the seminary there. Both of these places drew John powerfully, and he longed, oh, how he longed, to go to one or the other! The Franklin school, being farther away, seemed quite out of reach, but Harpersfield-Harpersfield!-the very name breathed romance and a world of possibilities!

The lad's yearnings, together with the pleadings of his mother, so moved the obdurate father that he again made John a promise: if he would work like a nailer through the fall, he thought he could manage to send him to Harpersfield for the winter term!

Day by day in the September weather, John followed the plough on the side-hill lot above the sap-bush, crossploughing to prepare the ground for rye. His hands were 


\section{JOHN BURROUGHS-BOY AND MAN}

on the plough-handles, but his head was in the clouds, and Harpersfield was at the end of every furrow! It was a world of alluring day-dreams in which he dwelt, as, following old Prince and Pete, though jerked about by the plough-handles, he moved in an enchanted land.

Yet, dreamer that he was, he never lost interest in the wild life around him; many a pleasant incident marked his humdrum toil. Like the Poet Plough-boy of bonnie Scotland, our Plough-boy of the Catskills one day unwittingly routed with his cruel colter a "wee, sleekit, timorous beastie" from her nest. It was the little white-footed mouse, the deer mouse, which, as she scampered away with the young clinging to her teats, looked like the "raggedy man" of Mouseland. She jumped so fast in her fright that some of the young fell off, but, plucky little mother that she was! running to a place of safety with the hangers-on, she soon returned and searched for the backsliders, which, on finding, she seized as a cat does her kittens, and made off right speedily.

When winter came, alas! it proved to be the winter of our hero's discontent. Dick Van Dyke went back to school alone-the expense looked too big to John's father when the pinch came.

"He didn't mean to break his word," says the son in later years, "but there was very little money. I often wonder how they got along as well as they did with so little." Bitter as was the disappointment, he swallowed it in silence, no one but his mother divining how bitter it was.

Going for his last term at the home school that winter (1853), he studied with unwonted earnestness, buoyed up by the determination to get away to school soon on money of his own earning. 
Years after, in speaking of this he said, "I was better unhelped, as it turned out, and better for all I could help father. He could not understand my needs, but love outweighs understanding, and he was a loving father all the same."

He cannot, even now, hear the name of Harpersfield without a momentary glow on his mental horizon, it was so interwoven with his youthful hopes and dreams. He often says he is not so sure but that he had the best of Harpersfield after all, since the desire to go, the effort to make himself worthy to go, the mental awakening and the high dreams were, after all, the main matter. "I doubt if the reality," he adds, "would have given me anything more valuable than these. The aspiration for Knowledge opens the door of the mind and makes ready for her coming."

(More than sixty years after those Harpersfield longings, the grown-up boy took some of us in his car to Harpersfield-his Carcassonne! All eagerness as we set out, and talking animatedly, he grew strangely quiet as we neared the place. The seminary was no longer standing. He wandered alone up and down the little street, as though in search of something, and we who looked on at a distance knew that the Harpersfield he beheld was not the sorry little hamlet which we saw, but the Harpersfield of that Plough-boy's dreams. Though walking near us in reality, he walked alone and lonely there, down the Street of Lost Time.

"Alas!" said he, on rejoining us, "here are only the ashes of my boyhood dreams - the Academy, they tell me, was burned years ago.")

That winter, engaging in some of the pleasures of a 
grown-up youth, John began to be more concerned about his personal appearance; he sometimes indulged in a hair-cut at the village barber's, and sported a pair of fine calfskin boots, with high heels, elegant affairs which he wore to the neighbourhood apple-cuts with bashful pride.

Apple-cuts, which were held around at the various farm-houses in the late autumn evenings, were the chief social affairs of those days. The young folks went dressed in their best; the girls brought their aprons and paringknives, the boys their jack-knives. The extravagance of several lighted candles was afforded on such occasions. One person sat at the machine and pared the apples, while the youths and maidens sitting around cut, cored, and strung them for drying. It is said that there were often other things cut and dried at those old-time gatherings besides apples.

The work progressed amid great chattering and chaffing, and after pie, doughnuts, and cider were served, they sometimes danced, though this was regarded as sinful by their parents.

Once at an apple-cut at the Burroughs homestead, the parents being away, Hiram proposed a dance, but Jane, who had been recently baptized over in the creek at Stratton Falls, protested against so sinful a pastime. Hiram and John, unregenerate that they were! being deaf to her scruples, the dance was soon well under way, Hiram playing the jewsharp, John calling off. The awkward youths and shy maidens were fast losing their bashfulness in the mazes of the quadrille when conscientious Jane rang the curtain down on their pleasure. None could be deaf to the persuader to which she resorted: Seizing the din- 
ner-bell, she rang it with such prolonged zeal that the revellers were forced to abandon their unholy frivolity.

There was a jolly old sailor who sometimes fiddled for them at the apple-cuts, singing rollicking ditties as he played:

Oh! my Bowery girl, ain't ye comin' out to-night?

Ain't ye comin' out to-night?

Ain't ye comin' out to-night?

Oh! my Bowery girl, ain't ye comin' out to-night

To dance by the light of the moon?

Oh! I danced all night and my heel kep' a-rockin',

My heel kep' a-rockin',

My heel kep' a-rockin',

Oh! I danced all night and my heel kep' a-rockin'

An' I danced with a gal with a hole in her stockin'-

The purtiest gal in the room!

And down he would bring his foot with a rousing slam at the end!

At an apple-cut over in the West Settlement it seemed to be generally understood that Jim Bartram was to see Jane Burroughs home, and all the young folks were expecting that John would be equally gallant and see Eleanor Bartram home-little Eleanor of the pink sunbonnet, the sweetheart of his childhood. He knew that this was expected of him, suspected that Eleanor herself expected it, and even had some hankering after the experience; but he was very bashful, and there were those blackguarding boys and giggling girls standing around while he valiantly tried to muster up courage to step up and say in his most polite manner, while offering his arm, "Please may I see you home to-night?"

Eleanor was walking demurely alone behind a blushing couple who had already run the gauntlet. As she neared 
the place where John stood, he made a start, then drew back-no use, he couldn't screw his courage to the point, and little Eleanor tagged along, unescorted, behind her sisters and their beaux.

John had to stand a good deal of bantering the next day:

"Did you have your 'mitten' on, John?" "Maybe he was afraid Eleanor'd give him the mitten." "Afraid of a girl, were you?"-taunts like these were volleyed at the diffident suitor, till in desperation, he blurted out, "I'll be darned if I'd go all the way down the road with her, and come back alone over the hill in the dark." And, if the truth must be told, that was the "cheese" of it!

There came a time, however, and not many months later, when he conquered this difficulty. He was soon calling of a Sunday night at a little red house in the village and paying bashful court to gentle Mary Taft, toward whom he had long felt a decided leaning, in spite of her having eaten so greedily of his maple sugar a year or two before.

Those Sunday night visits were a sort of "linkèdsweetness-long-drawn-out." The bashful pair sat at a respectful distance from each other. The conversation was never brisk, and the swain would get pretty sleepy before midnight. Promptly on the stroke of twelve, Mary would withdraw, returning soon with a pie and a cake, after which the talk would grow a bit livelier. "The Lord only knows what we talked about," Mary's reticent beau declares. After refreshments were discussed, the hours again dragged wearily on until two-the accepted time for such visits to end-to leave earlier were to slight the maid! There was no fear of the dark then as he started on his homeward walk over the hills and through the woods. 
He only wondered how soon he might arrange to call on Mary again. If one went every Sunday night, it meant an engagement; he was circumspect and ruled that out; but, asking himself whether he would wait two, or three, weeks, he strongly inclined to but two.

Such allurements, however, did not make him lose sight of his resolution to earn money in the spring for some real schooling, and in late March, shortly before his seventeenth birthday, he started out to seek a place as teacher. He went down into Ulster County, to Dr. Hull's, a friend of his father's, to seek a school-his only journey of any account since when, a lad of eleven, he had gone to Catskill on his father's load of butter!

With his black oilcloth satchel in hand, and a few dollars in his pocket, earned, as usual, by making maple-sugar, he went forth with a heart full of vague yearnings and forebodings.

There was a heavy snow-squall as he crossed Batavia mountain into Red Kill, going over the saddle of the mountain and following the same course his father used to point out as the one he had taken on his old sorrel mare when courting John's mother. Walking the eight miles to Uncle Martin's, he was driven next day to Griffin's Corners to take the stage-coach for Olive.

Standing in the tavern door while waiting for the stagecoach, he was anxious and uncomfortable. He did not even know how the "stage" would look; knew not in the least how to act, nor what would be expected of him. Learning at the tavern what the fare would be, he paid it at the rate of a six-pence a mile for some thirty-odd miles, and soon after saw the old Concord coach, drawn by four horses, come driving up with a flourish. The young trav- 


\section{0}

\section{JOHN BURROUGHS-BOY AND MAN}

eller watched them enter his name on the way-bill, and, at the brusque command of the driver to hustle, climbed nimbly to the top of the coach behind the driver, his heart beating violently as they started off.

On leaving the snowy hills of Delaware County and dropping down into the milder climate of Ulster, John grew more and more homesick, but on reaching the old Doctor's, was greatly cheered by the warm welcome he received. The next day, riding with the Doctor on his rounds, he made inquiries everywhere about schools in need of a teacher. After three days of this he heard of a school eight miles away, in Tongore, and walking there, hunted up the trustees, and made application. How uncomfortable he felt as they looked him over sharply, questioning him as to his ability!

"I cal'late ye hain't had much experience," said one of them, "but we'll let ye know in the course of a week, or sech matter."

It was the first day of April when he started back home, a few days before his seventeenth birthday. As they stopped at the same tavern to change horses, seeing a copper cent lying on the floor, John stooped to pick it up, but found it nailed fast. Great was his mortification, and keenly was he aware of the sly looks and chuckles of bartender and bystanders!

Before the week ended a letter came from the trustees bidding him come at his earliest opportunity. Wages were to be ten dollars the first month, and eleven a month for the other five if he should prove satisfactory, "and board 'round." Elated, he answered that he would be on hand to open school the next Monday.

Then came the real leave-taking. His mother was full 
of anxious care as she mended and packed his clothes. Breakfast was over before daylight, the lunch was put up, and all stood silently around to say good-bye to John, going away from home to "keep school." The father was silent, the mother was silent, too, but busy, proud and anxious - her boy, John, the apple of her eye, was going out into the world alone! Did her divining heart know that he was going to meet renown? that he was going to do work of enduring worth? that he was going to write his name deeply on the hearts of men? The brothers hung around, half envious, half incredulous of his success; his sisters stood by shy and tearful, and with a lump in his throat and a wistful look at the group on the doorsteps, the agitated lad climbed up on the spring-seat beside his father, and they drove briskly the ten miles to Dimmick's Corners (now Arkville) to meet the "stage"-John, especially, in trepidation lest it leave before they should get there.

He felt more experienced as he mounted the Concord coach for his second trip. In due time the rocking vehicle set him down at Terry's Tavern, whence he walked the few remaining miles to Tongore in the April twilight.

The little spring peepers were piping in the ponds, and the familiar sound made the pent-up feelings of the homesick boy almost burst their bounds - this boy starting out to work his way in the world! He was very forlorn. Oh! if he were only home again! If he could only see the old hills instead of this strange land! But, no longer the child of four on that first journey on the Deacon road-the child that had looked back, and on seeing how far he was from home, had ran back as fast as he could!-there can 


\section{JOHN BURROUGHS-BOY AND MAN}

be no running back now! he must push on, wherever the road leads!

The long road at last had a turning. Just as the weight on his heart was the heaviest, he spied a man with a strangely familiar gait coming around a bend. His heart leapt up as he beheld Neighbour Scudder, Rube's father, who had been to Tongore to deliver a yoke of oxen. Cheered by the brief encounter, John made the rest of the journey with a lighter heart. Soon he was almost exulting in the new experience. To-morrow he would begin teaching! His wages would enable him to go away to school!

That night his head fairly buzzed with plans and projects and it was long before he fell asleep.

It was a different world into which he awakened. Though still thinking wistfully of the home amid the hills, he followed eagerly the beckoning Future.

The Plough-boy went forth to make his dreams come true! 


\section{YOUTH}





\section{CHAPTER $\mathrm{X}$}

\section{TEACHER AND STUDENT}

(1854-1862)

JoHN's desire to teach had come about in a purely imitative way. Other youths in Delaware County who had had the ambition to do something besides "farm it" had gone down to Ulster County and taught school, so when he was casting about for means of earning money he followed their example, not so much because of an inclination to teach, as that it seemed the most likely way in which to earn the money to send himself to school.

Motor parties going around the Ashokan Reservoir, that stupendous engineering feat by means of which New York City is supplied with its Catskill water, may note a signboard on the southern shore indicating Tongore, two miles away. In that obscure hamlet, at the foot of Olive mountain, in a little red school house, still standing, John Burroughs began his career as teacher, on April 11, 1854, shortly after his seventeenth birthday. His wages, as we have learned, were ludicrously meagre, and in boarding round he sometimes fared pretty poorly with the sour bread and "frowy" butter occasionally set before him. At one place, boiled potatoes and salt constituted the entire meal. Once a rickety bedstead broke down with him during the night, but he clung to the wreck till morning and said nothing about it even then. As a rule, however, he fared well, sometimes even sumptuously, "Teacher" 
usually being treated to warm biscuit and honey, or pie, for supper, in addition to the regular fare. There was pie for supper, pie for breakfast, and pie for his dinner-pailin fact, he says his early piety is probably responsible for the digestive troubles that have clung to him throughout maturer years.

Twenty or thirty pupils comprised his first school, their ages ranging from six to thirteen. He can recall the names and faces of most of them to-day, especially a slender, clean-cut girl, a little fat, freckle-faced girl, a thin talkative girl with a bulging forehead, and three of the boys who became soldiers, and fell in the battle of Gettysburg.

$\mathrm{He}$ had a good school, not so much because of skill as a disciplinarian, as that he secured the good will of the pupils, and could impart knowledge easily. He was himself, he admits, crude and callow; full of vague aspirations; undisciplined; unsophisticated; bashful, and given to stuttering when embarrassed.

Some of his first wages as a teacher went for a Letter Writer, purchased of a peddler, from which he modelled stilted epistles to his sweetheart Mary. The timid answers in her graceful, girlish hand are still preserved, but what would one not give to see the absurd letters which called hers forth! Granther Kelly died that season, and John modelled a letter of condolence to his people upon one in the book, cringing in later years to think how absurd and unreal it must have sounded to his family.

A work on phrenology occupied many spare hours during that term, and a dollar and a half of his wages procured a chart of his head, the young philosopher beginning thus early to heed the injunction, Know Thyself. 
Sometimes of a Sunday he sat restively in a pew of the old Methodist meeting-house. It is to be hoped his father never knew it; although it was not the free grace of the Methodist doctrine that so much attracted him as the natural grace of certain maidens who frequented that church; these compensated for his sacrificial chafings under the long sermons of Dominie Barber, whose discourse was "like a dog chasing his own tail." Once he went forward at a revival meeting there, but when the miraculous change which he expected did not come, he decided to work out his own salvation in some other way.

That was a long summer to him. He had never been away from home more than a day or two at a time before, and was often homesick. But though longing for a sight of the old hills, he stuck it out until the term ended in October, then took with him a chum, a brother of one of the girls for whom he had a passing fancy. $\mathrm{He}$ also took fifty dollars of his wages, which precious money, with a little more earned on the farm, paid his board and tuition for three happy months that winter at the Hedding Literary Institute at Ashland, N. Y.

It was a joyous youth who started out in late November, the time of year when the farmers took their butter to the Catskill market. John, on the high spring seat, made the journey with his father as full of eager excitement as when, a lad of eleven, he had first taken the trip.

There were two hundred or more youths and maidens at the Institute. John was present at the dedicatory exercises in the chapel. His studies were algebra, geometry, grammar, chemistry, French, and logic. He was also required to write compositions, and to deliver declamations. The untried ever has its charms: John chose logic because 
he had never heard of it before. Their class met at seven in the morning in the dimly lighted chapel. Instead of logic, the young ladies of the school took a course in Wayland's Moral Philosophy, for which their masculine schoolfellows had a withering contempt. Both sexes parsed from Paradise Lost, a poem of which, I venture to say, youths of to-day have scarcely read a line. When John came upon Milton's account of the celestial warfare, at first astonished, he soon shocked his school-fellows by declaring he did not believe a word of it.

About this time his bent toward writing developed conspicuously, his compositions usually receiving favourable comment. The opening sentence of an out-door essay written while there still lingers in his memory: "The last sun of 1854 was gilding the tops of the western hills."

In recent years when urged to recount his life at the Ashland Institute, he says there is but little he recalls. He remembers when his parents came to see him, bringing mince pies, doughnuts and other goodies from home, and staying with him a few hours. He can see yet how queer his parents, country folk that they were, looked and felt in those strange surroundings. His elder brothers came also on sleigh-rides with their "girls." There is one incident, absurdly unimportant, which he recalls with amusement:

I remember the old cow I saw break through the ice into a cistern of water-it was a hogshead sunk in the ground-I had seen her nosing around it for some time, trying first one foot, then the other, when suddenly the ice gave way and in she fell, her tail hanging over the edge. She would have drowned if I had not given the alarm. Some of us got hold of her horns, and some of her tail, but the more we pulled her tail up, the more her head went down. With planks and things we at last succeeded in rescuing her from her cold bath, but we nearly pulled her tail out by the roots. 
That winter the young student bought a French Dictionary and Blair's Rhetoric from a Texas boy who was hard up. He studied the rhetoric diligently the following summer, though with little benefit, he thinks, and soon traded it off for other books. He still has the dictionary.

About this time some lectures by a Doctor Lardner fell into his hands. He remembers the elaborate arguments of one of them in which the writer conclusively proved that a steamship could never carry enough coal to take her across the ocean; but as it was not long after reading those arguments that he learned of a steamship going across, his confidence in logic received a severe shaking up.

Toward spring John was one of the disputants in a public debate. The Crimean War was then on; they debated this question, John taking the side of England and France against Russia. He was the first to speak. He remembers getting much of his ammunition from Harper's Magazine. His fellow on the affirmative had, unfortunately, levied on the same source, so was up a stump in earnest when his turn came, but in spite of that, their side won.

Among his schoolboy keepsakes I find a letter from one of the Ashland pupils, E. Bogart, whose quaint handwriting and stilted phraseology reveal other times than ours. It mentions certain current news items of their day which have long been regarded by us as historical. Young Bogart writes:

... I presume you have heard of the death of the Emperor Nicholas, the taking of Sebastopol, and also of Dr. Kane's return from the search for Sir John Franklin, . . . but with the events and circumstances peculiar to my own private life, perhaps you are not so familiar. . . .

And he proceeds to tell, in a stilted way, of changing from that "honourable, honest, primeval employment of 
Adam's progeny, viz., a tiller of the soil," to that of a "trainer of youth."

I find among those schoolboy possessions a little memorandum-book by J.Burroughs, bearing the dates 1853-1854. His handwriting from the ages of sixteen to seventeen, graceful yet forceful, showed a tendency to shading and ornamentation. The spelling was poor. Spelling always has been one of his weak points. To this day he confesses he would be spelled down on certain words, for example, separate, vegetable, mosquito, chipmunk, and terrestrial. (At one time, a few years ago, he consented to join the Simplified Spelling League, thinking himself in favour of it, "as all poor spellers are," but on finding himself flooded with their "literature," he bolted, declaring it a great nuisance, adding humorously, "besides, it's harder than the old way.")

The little notebook just referred to is an amusing hodgepodge: Several pages of algebraic formulæ are followed by a record of the days he taught in his first school. On one page are directions for dancing the quadrille (probably made during the apple-cut period, before leaving home):

\author{
Right and left-4 \\ Balance-4 \\ Ladies change (sic!) \\ Promenade \\ Balance all \\ Swing-Adamant (sic!) left \\ All promenade, etc., etc.
}

"What does that mean-'adamant left'?" I ask of its recorder.

"I don't know-it was something that sounded like that, I suppose-I never questioned it-we used to say it that way in calling off." 
Racking my brain, I tried to recall what it was they used to say in the days when I threaded the mazes of the quadrille. Finally it came to me-his "adamant" was "Allemand" - to the German, even in those days, was attributed some of the adamantine quality we have come to associate with him in recent times.

Here is the entry which fixes the date of his first letter from Mary, his Roxbury sweetheart, others being duly recorded later. Next come entries in his expense accountstationery, horse and buggy, supper and fiddler's bills, hat, coat and vest, gloves, $a$ ring, shoes, cards-the swain was attending to his wardrobe then (probably while teaching at Tongore), taking his "girl" out to drive (evidently not Mary, but some nearer charmer), and treating her to suppers.

Following this is a list of those first studies at Ashland, with the hours of recitation-algebra, geometry, French, Kemistry (sic!), physiology, and logick!

Now we come upon grandiloquent passages, evidently copied from things he has read. "I suppose I thought that was good style"; he laughs as he reads the sentences that so impressed him then, and recalls how sorry he once felt for a boy in the Ashland school, who in a composition having used the expression "the endless ages of eternity," was compelled by the teacher to strike out "endless" as superfluous-" I thought it was too bad-that sounded so fine!"

Here is a list of schoolboy names-some committee in the debating-club at the Institute; then some undecipherable notes on logic, this time without the $k$. Here are groups of mere phrases, "halo of genius" is one. "That was probably a new expression to me," he explained. "Oh, 
those days of the callow youth when he is taken with words, words! he has no ideas, so the more grandiloquent a thing is, the more it takes his fancy. Oratory was more to the front then than was the art of writing. I guess boys of to-day like less beating about the bush, and simpler, more direct methods."

Now we come upon scraps, evidently his own, and now citations from the Bible.

Next comes his sweetheart record, the dates when he called on various girls-one Melissa and two Marys are on the list.

The beginnings of compositions evidently suggested by his studies in physiology follow next, and fragments of sentences. He seems to have been meditating on several subjects, and trying various ways of saying the same thing. More extended fragments follow, then mere jottings of words-strabismus, ennui, predestination-then various anatomical terms, and more Biblical citations.

At the last is a defence of phrenology. "It was partly my own, I suppose," he explained, "and partly from the Phrenological Journal. I must have been trying to string those sentences together-poor, high-flown stuff! I had no ideas and was just playing with words, you see. I suppose that is the way many begin to write."

At the close of the April term at the Institute, after a short stay at home, with ten dollars advanced by his father, he made his first journey to the city of New York, going by steamer, his main object being to find a position for the summer as teacher in New Jersey. He had in his pocket a letter of recommendation from the principal at Ashland, a document stating that John Burroughs was competent to give instruction in the branches usually 
taught in district schools, and that the writer could cordially recommend him as "a gentlemanly, earnest, and faithful young man."

Of that first ride on the steam-cars, from Jersey City to Plainfield, he remembers chiefly his anxiety as he sat waiting for the train to start. He actually wondered if the starting would be so sudden as to jerk his hat off! He recalls but little about the train itself, except that the brakeman stood outside and worked a wheel-it was long before air-brakes were in vogue.

Finding one school still unsupplied in New Jersey, he walked twelve miles to see its trustees, who, on looking him over, decided he was too young and inexperienced for their school. So it was a crestfallen youth who stayed that night at a little inn in the village. The occultation of Venus by the Moon, which occurred that night, held him long and long. In the morning he tramped the twelve miles back to Somerville and turned reluctantly toward home.

In passing through New York that day he spent several hours loitering about the streets and hunting up the phrenological establishment of Fowler \& Wells, but, on finding it, could not muster up courage to enter, though he walked back and forth past the place many times, peering wistfully in at the windows.

Probably one of the most important experiences of his life occurred right here: It needed no courage to approach those shabby little second-hand book-stalls which stood along the curbstones in William Street. They were under his very nose, and the humble vendors in no way intimidated him. He browsed from stall to stall for nearly half a day, unmindful of all other attractions in the great city. 
Handling eagerly book after book, he dipped into them here and there, books which to have owned would have made him as rich as Crœesus. At length, having singled out quite a sizable pile, he timidly inquired the cost. As the vendor was looking them over to estimate the price, he took out his money and began counting it. Curiously enough, or so it seemed to him (the shrewd vendor doubtless having seen the extent of his cash), the books came to eight dollars-just about what he had left. Then began the harrowing process of deciding which of the selected books he would keep, which forego. He already had his return ticket on the boat to Kingston, but there was the stage-fare, also supper and breakfast, to be reckoned with. But the books won. He could go hungry for them. They would last after his hunger was forgotten. If he paid his fare on the stage as far as Dimmick's Corners, he could easily walk the remaining twelve miles. So, after a little further sifting and weighing, he gave up a few of the books, but still had a goodly pile left, and excitedly packing these into his bag, was soon lugging them up the gangplank of the Hudson River steamer bound for Kingston.

A peep, as it were, into that black oilcloth bag shows us: Saint Pierre's Studies of Nature, Locke's Essay on the Human Understanding, Dr. Johnson's Works, Spurzheim's Phrenology, the Works of Thomas Dick, a Scottish philosopher, and one or two others. All of these cherished volumes, except the works of Dick, are still on the shelves of his study to-day. He had been attracted by the opening sentence in the first volume of Dick-"Man is a compound being." It had whetted his appetite, but he soon got all he wanted of Dick, and later traded his works off 
for others. "What twaddle it all was!" is his comment now concerning Dick.

From Kingston he rode as far on the stage-coach as his money would take him, then walked the remaining twelve miles home. As he crossed the mountain, carrying the heavy books, his pockets were empty, and his stomach was empty, but his heart was light because of the very weight he bore.

This was only one of many extravagances at those old book-stalls. For years, whenever he visited New York City, he hovered around them as a bee around a buckwheat field. Nearly all the copies of English classics in his library were, from time to time, picked up at those curb-stone stalls.

It was on a subsequent visit to New York that our verdant youth had an experience with the confidence men. He stopped at a Peter Funk auction, where watches were selling cheap, and bid one in for six dollars. No sooner had he bought the watch than a man standing near told him the watch was no good; that it had no lever; and that he better pay a little more and select a watch he could examine and be sure about. He had handed the salesman a ten dollar bill and received four dollars in change, but on his second selection of a watch, he found its price to be ten dollars. So they got all he had, while he found later that although he had bought two watches, he had been "sold" in both deals-the ostensibly friendly bystander had been a wily accomplice of Peter Funk.

Though working on the home farm, he spent much of that summer of 1855 in reading. He sauntered in the familiar fields and woods with Locke, Spurzheim, Saint Pierre and Johnson for companions. These weighty 


\section{JOHN BURROUGHS-BOY AND MAN}

books were not, however, the only ones he read for he devoured his first novel that summer-Charlotte Temple, reading all one night, finishing it in the early morning just before going out to the hayfield. How the homely scenes revolted him that day! The novel had let loose a flood of emotion in him, very probably causing some loss of appetite, for a time, for Locke and Johnson.

In the fall he again set out to look for a school, thinking to try again in New Jersey, but stopping at Olive by the way, was persuaded to teach again in the school at Tongore, and at double his former wages - the munificent sum of twenty-two dollars a month, and board. It was at this time that he first saw a postage stamp. During this term he met Ursula North, a handsome dark-eyed niece of one of the trustees, a meeting which sealed his fate.

The books of the pompous Johnson were now beginning to get in their work. During this second term of teaching young Burroughs practised at essay-writing a good deal, deliberately modelling his essays on the Johnsonian style, not having learned that big words do not necessarily mean big thoughts. After a little he gave up this imitation of Johnson, but even then was slow in perceiving that the secret of good writing is to bring yourself face to face with your reader.

The first appearance of John Burroughs in print was in May, 1856, in a little country newspaper in Delaware County, the Bloomville Mirror. In that first literary venture he adopted the pen name, Philomath, a lover of learning. His article, about Spiritualism, was in reply to a too credulous writer in a previous issue. How Philomath did haul that poor writer over the coals for his unreasoning credulity! Abounding in big words when simpler ones 
would do, the article expressed impatience at the gullibility and superstition of the adversary; and derision at his acceptance of "proofs" that were not proofs; it was, in fact, unmercifully critical; yet showed clearness and force, and, on the whole, was a remarkable production for a youth of nineteen. Already one discerns the independent thinker, the eager searcher after truth, the uncompromising hater of shams. This effusion came out when he was in the first flush of student days at Cooperstown Seminary, whither he went in the spring of 1856 .

During those three months at the Seminary, he continued the study of mathematics and French, took up Latin, and studied English literature. He stood first in composition in the whole school, debated in the Websterian Society, and on the Fourth of July delivered an oration on the shore of Lake Otsego, in true spread-eagle style. A Seminary program of exercises of that year states that one of the Websterian debates was: Resolved that the career of Mahomet was more beneficial than injurious to the world; and that J. Burroughs was speaker on the affirmative.

A few years ago in ransacking some old papers in his study, we came upon a schoolboy essay, "Work and Wait," written by him at Cooperstown that July (1856). It is a serious-minded production, whatever else may be said of it. It was fun to watch its author as, holding the yellowed paper, he read aloud, with mock solemnity and exaggerated rhetorical effect, this early effort-the shaded, ornate handwriting, the poor spelling, the platitudes, the grandiloquent passages, the moralizing, all coming in for a share of his ridicule. The gist of the composition is shown in the title; success comes only by patient effort; 


\section{8}

\section{JOHN BURROUGHS-BOY AND MAN}

facts in nature, history, and biography were solemnly set forth to prove the point:

Let no one be captivated with the vain conceit that he was born great, and that he may attain real excellence without labour and application. It is not a thing obtained so easily; it is not a bauble to be purchaced [sic!] by a groat, nor an unsubstantial fairy thing to be wooed and won by the wishing only. It must be corted [sic!] with patience and assiduity.

And so it continues, tracing the career of the dauntless workers in life's battle who breast the storm with every prop knocked from under them; who conquer in spite of all attempts to frustrate them; who force all opposition to yield to them-men who are the "pillers [sic!] of the state," the bulwarks of the church- "men who ever stand firm upon their principles amid the fluctuating waves of party politics, or the howling blasts of popular opinion." One can fairly hear the youthful orator's eloquence ring through the academic halls!

Happily, while at Cooperstown, the ease and grace of Addison and Lamb caused the plastic, imitative student to swing away from the pomposity of Dr. Johnson. In poetry his taste was then for Pope and Young. He knew nothing of Chaucer or Spenser, and little of Shakespeare. As for Emerson, when he took his first bite of him that summer, "it was like tasting green apples." Other mental stimuli were furnished by lecturers (Parke Benjamin and others came there through the efforts of the students' debating society), likewise by the sermons of a Universalist preacher in the town, a man who "had a direct and pointed style, like an essay." John and a chum used to go often to hear him, though most of the teachers and students disapproved. "They were afraid of Univer- 
salism," he explained, "afraid that everybody would go to heaven."

A never-to-be-forgotten thing happened to him one evening as he was walking alone down the main street in Cooperstown-he saw his first author! Following him from afar in the twilight, he looked upon him with an awe and reverence never before felt for any human being. The man was an obscure author of a history of Poland, but to the imaginative, aspiring youth who had just felt the joy of seeing himself reflected in the Bloomville Mirror, that glimpse of a real live writer was a momentous experience.

There were, however, games and other activities and interests that vied with literature and literary aspirations during that term; rowing on the lake, baseball, and other sports claimed a fair share of time. That love of comrades, always strong in him, was not confined entirely to those of his own sex, is testified to by several demurelywritten letters (in pale blue ink, on dainty diminutive pale pink or white embossed sheets), despatched to him after he had left school, and preserved by him throughout the years.

A program of the Students' Exhibition, held that summer at school-close, announced, among other interesting items, an essay by John Burroughs, entitled "Goodness Essential to Greatness" - not a bad conviction for a youth to hold in starting out on his career!

With that three months at the Cooperstown Seminary our student's schooling ended. All that he achieved thereafter was from the push of his own endeavour.

His funds were low as he started for home; but riding all night in the stage, he was carried as far as Stamford 
and there set down at daylight in front of the tavern, whence he trudged hungrily across the Hardscrabble mountain to his home. "In those days," he said, "I could go all day without eating, or I could eat all dayjust as it happened."

By a curious coincidence there fell into my hands a few years ago a letter written by John Burroughs at the age of nineteen to one of his Cooperstown classmates. I hope it is not taking an unfair advantage of that youth to quote it as a sample of how boys wrote to one another in 1856:

Friend Paine:

Roxbury, N. Y., August 4, 1856

In compliance with your request, and in keeping of my own promise, I sit down to indulge in a "silent chat" with my quondam class-mate, friend Paine. Social intercourse is said to be the source of the most refined and lasting pleasures that it is the prerogative of man to enjoy, because it calls into action the highest faculties of his nature. Whether this be true in every case, we will not presume to determine, but it accords with my own experience thus far: that the friendly exchange of thought and feeling, whether it be by the tongue or pen, with those who have shared with us the pleasures and pains of life (especially a student's life) and who have not infrequently contributed to our success, is one of the most delightful privileges that I can enjoy. But I am too serious and speculative. How have you been prospering since you left the Sem? What is your employment? "Ploughing the classic soil?" Conjugating Latin verbs? 0 , deliver me from such an ordeal, from the arem and arer! I presume, though, you are not wandering in such misty labyrinths, but at that other more natural employment for which your genius is so peculiarly adapted, courting the favour of the Muses.

Go ahead-may they guide your pen and inspire your thoughts!

I have been exercising my physical powers since I left Cooperstown. I have been wielding the scythe more than "the old grey quill." You know the body must work as well as the mind in order to preserve the equilibrium, and fit the man for accomplishing "big things." No one can have a strong mind without a healthy body, and no one can have a healthy body without physical labour-work, therefore, if you would be somebody. 
How are all our schoolmates that live in your country? très bien, I hope. Remember me to them kindly, especially the ladies, for you know I would not like to be forgotten by them.

What are your prospects for the future? I think of embarking soon on a southern expedition, if friend Keyes does not disappoint me. I hope Fortune's breeze may waft us triumphantly to the haven of success. Exert yourself, Paine, if you go back to Cooperstown. Let your mark stand high up the pilgrim's pathway. He who aims at the moon will shoot higher than if he levels his gun at a tree. This is true in morals as well as in sporting.

We had some grand times at the Sem, did we not, Paine? Do you remember the morning that we went to see "Old Dame Nature"? She is a kind old lady! In her lap are pearls of the richest hue, treasures richer than Pluto's mines, and she deals them out with a bountiful hand to all who are pure enough to appreciate them. Think you we will ever have any more such times, Paine? "Life is but a flower that blossoms and is gone." And its leaves may fall ere we meet again, but I hope not. I hear the rain drops spattering against my window. It makes me rejoice for it has not rained before in a long time-it has been very dry.

But I must close this hasty scroll. Write soon. I may be gone from home in two weeks. My compliments to your sister. Adieu.

Yours truly,

JoHN BURROUGHS

L. B. PAINE, Gent.,

Garrattsville, N. Y.

Stilted schoolboy letter that this is, it reveals certain traits which have been characteristic throughout the life of its writer-love of comrades, an early, abiding, and pronounced leaning toward feminine society, distaste for drudgery, a wholesome commingling of physical and intellectual activity, concern for the preservation of good health, love of nature, an ingrained tendency to reminiscence, and a strong vein of sentiment counter-balanced by practicality.

The next move the youth made was to go West. After the fall work was done on the farm, borrowing fifty dollars from his brother Curtis, he set out (1856) for a little town in Illinois, called Buffalo Grove, near Polo. He had 


\section{JOHN BURROUGHS-BOY AND MAN}

been attracted there by letters from friends he had known at the Ashland school. There he again engaged in school teaching, and during the six or seven months' stay, grew rapidly in mental stature. Several things contributed to this besides his own thirst for knowledge and his philosophical bent: he was surrounded by intelligent and congenial friends, he had the stimulus of improving lectures, and access to a good library, but perhaps most of all was the sudden kindling of interest in Emerson. Ready for him now, he devoured everything of his that he could find. He often says that he should like to believe that the young men of to-day find in Emerson what he found sixty and more years ago, when his startling affirmations put to flight a vast array of commonplace facts; when Emerson could whet his appetite for high ideals by referring to that hunger that could "eat the solar system like ginger-cake."

Yes, Emerson held him captive. He was Jonah in the Great Whale's belly. He could not get away from him, nor did he want to get away. Nature herself seemed to speak to him through Emerson, and the ardent, plastic youth was willingly enthralled.

During that winter at Buffalo Grove he saw himself in print for the second time, in an essay called "Revolutions," a florid, declamatory account of the progress of civiliza. tion from East to West. Here is a sentence from that early effort:

They [revolutions] are but the shocks from the car of Progress which so far from indicating the slackening of its speed, are the sure evidences of its increasing velocity.

(One would fain take comfort in this thought in the midst of the Bolshevism of to-day!) 
"Don't waste your time over it," he advised, seeing me reading it. "It's chaff, chaff-no wheat there." When reminded that there were truths in it, he said, "Yes, but only second-hand truths-nothing that I had thought out for myself. It was all the result of reading a book whose battle-cry was 'Westward the Star of Empire makes its way!" "

A young Scot whom he had hired to assist him in the school, having a printing-press, set up this essay for him. "I had given him a watch-chain that had cost me twenty dollars," he explained, "for which he never paid me, but gave me this instead-I'd rather had the twenty dollars."

That winter's work enabled him to add more books to his little library, books which he purchased at a little store in the village of Polo, of Dr. James More.

In passing through Chicago on his way home, he had his picture taken-a daguerreotype-probably the first picture he had ever had taken, certainly the first one extant. It shows a finely modelled brow, observant eyes, a sensitive mouth - the face of a poet, or a musician, the long brown hair giving it the look often seen in the portraits of certain musical composers. Those flowing locks, however, did not long grace the earnest face. His return was soon followed by his engagement to the girl he had left behind him, and, as she did not like the untrimmed hair which, she said, "made him look like a Methodist minister," compliant to her wishes, he had it shorn in regulation style.

"Oh, why did you do it?" someone asked him, years after, as he was relating humorously how his betrothed objected to the long hair, and she, sitting near, was preening herself, as women will, on having carried her point. 


\section{JOHN BURROUGHS-BOY AND MAN}

"Maybe he was afraid she wouldn't marry him, if he didn't," suggested one.

"Maybe he thought it was safer to have it cut, if he was going to be married," mischievously ventured Tim Silver, a neighbour sitting near, who, at the same time, ducked his head as though to escape a seizure from the nearby hand of his own wife.

That spring after returning East, John worked on the home farm till July, then taught at High Falls, N. Y., until the following spring, interrupting his teaching in September, 1857, when a little past twenty, to marry Ursula North, an energetic, thrifty, and forceful young woman of simple tastes and country breeding.

By this time he was earnestly reading and studying with a view to fitting himself for writing, although his wife was strongly urging him to abandon such aspirations and go into business. Her objections to his writing, however, were not on the same ground that a fond sister advised against it_- "I wouldn't write, John, if I was you," warned Jane, "writing, they say, is bad for the head."

His reading and meditation at this time evidently withdrew much of the interest which should have centred in his school, and he was chagrined at the close of the term to find that the trustee, in whose house they boarded, and who had always seemed friendly, did not offer to hire him again. Absorption in his studies, together with "squabbles among the women folks"--his wife and the wife of the trustee-were probably jointly responsible for his losing the school.

Back to the farm for the spring and early summer work, then teaching again from July till spring, this was the game of see-saw he played for most of the time between 


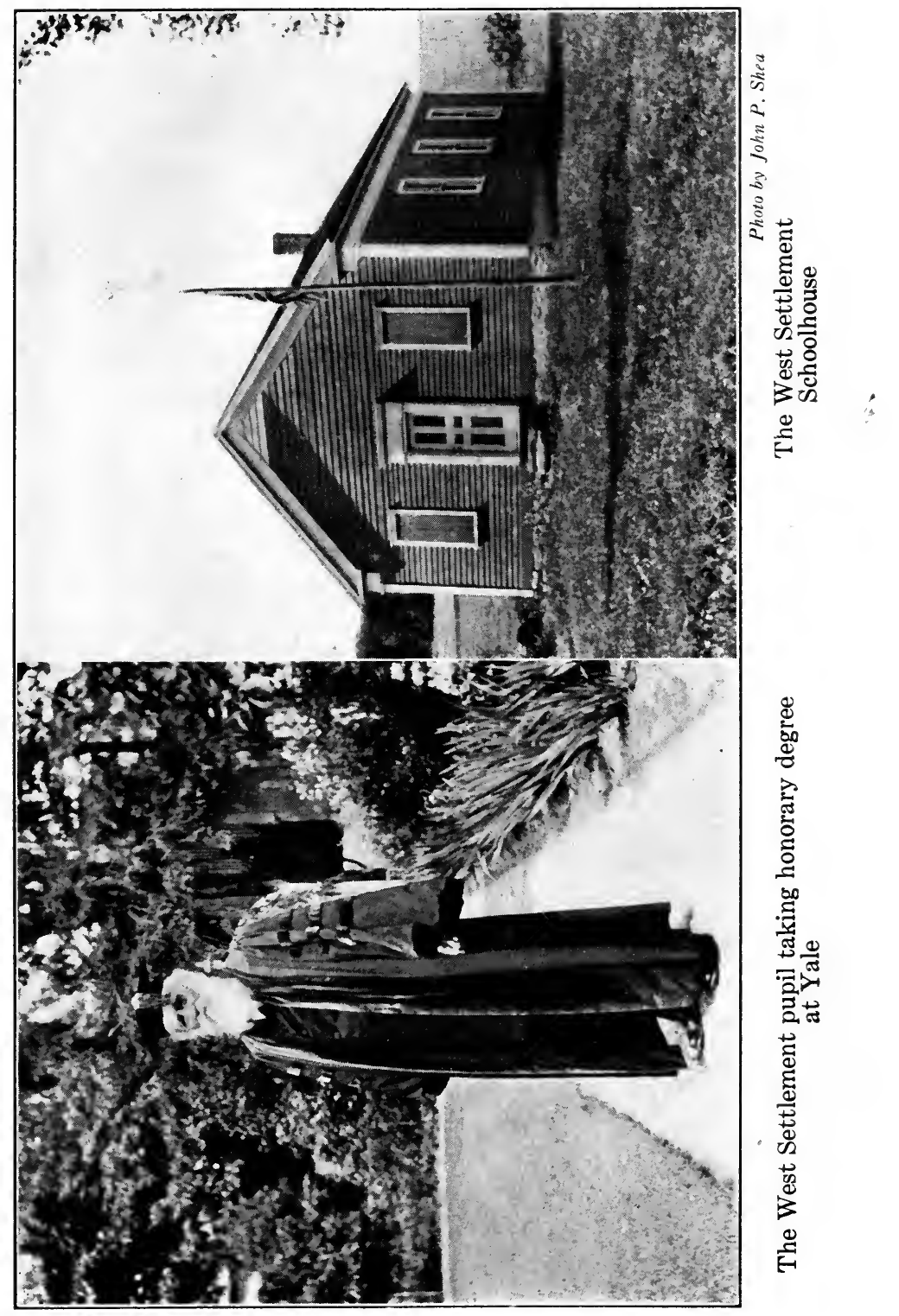




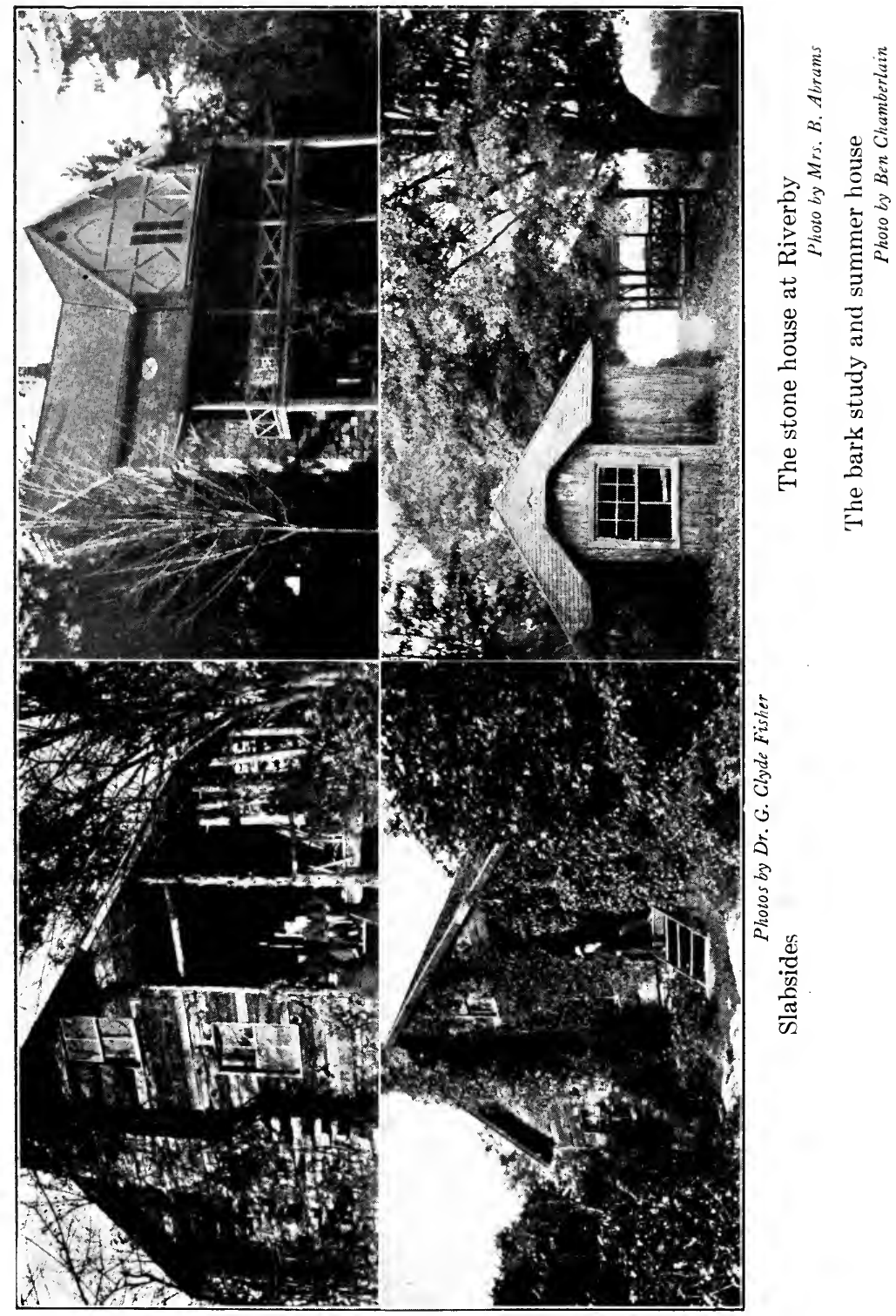


1854 and 1863. His next school was in the village of Rosendale, on the Rondout, his wife remaining at her father's home, he boarding at the village hotel. His evenings that summer were spent on the river with another youth, "fishing, reciting poetry, and cracking jokes," and his spare time in the berry season, in picking and drying raspberries, preparatory to housekeeping later on.

This period was one of marked mental growth. Two great influences, Nature and literature, were slowly shaping and moulding his life.

A belief in himself and his future held him to the task of teaching, irksome as it was, and poorly paid, since it afforded leisure for study and writing. Though being continually urged to begin a business career, he shrank from anything so foreign to his tastes, begging for more time to prove that he could yet do something with his pen. In one of his letters of that period he pleads:

You must not expect too much of me at first. I am very young yet and must study and grow, work and wait, before I can take the position in the world I shall be capable of taking. . . .

But in an evil moment he listened to the promptings of ambition, to reiterated advice, and to the plausible claims of a wily harness-maker who had invented a new kind of buckle for a harness-one with a direct draft on the tongue instead of the movable tongue of that then in use. Its inventor had asked the young teacher to make him a drawing of the buckle for the Patent Office, and while complying he had become so interested he decided to invest in the buckle himself. Visions of wealth allured him. He began talking up the buckle to everybody, and his enthusiasm made his hearers enthusiastic, too. A physician in the village, Dr. S-, was carried away by his 
eloquence, and together they bought the inventor out, he paying down all he could spare, the physician signing the note and agreeing to furnish him a horse and buggy to go about and interest the farmers.

Fired with belief in the invention, and with his glowing visions, he gave up his school in November and went to New Jersey where he had a large quantity of the buckles made, helping with them at the foundry, incidentally learning much about casting; meanwhile borrowing money from his father-in-law to meet the expenses incurred.

He placed buckles in various towns for sale, and still a lot were left on the maker's hands.

Then difficulties about the patent arose. The buckle seemed in some particular to infringe on one already patented. Everything seemed to conspire against the project: The foundry man lost interest in it; the Doctor's interest petered out, too, and he failed to furnish the means for going about to boom the buckle.

In time, he himself developed doubts of ever getting rich out of the venture. These grew to colossal proportions. After three weary months of attempts to get the buckle on the market, his hopes dwindled quite away.

He offered to sell out, but no one wanted his buckle. He was in a predicament. Having invested all his earnings, and some borrowed money-about three hundred dollars in all-he was dismayed to find that his entire capital of enthusiasm was expended also.

A disheartening period of seeking other work followed. He looked into all sorts of things in the effort to please his wife and get into business, but all required capital. A foundry was for sale: he investigated the business in all its 
details, all the time knowing how futile it was to consider it without funds, yet feeling the need of leaving no stone unturned. At last, convinced of the uselessness of such efforts, he wrote these convictions to his wife, setting forth the utter folly of further attempts to get into business without money, and with debts hanging over him. "To get rich," he wrote, "you must have something to begin with; as the old proverb says, "To bring home the wealth of the Indies, you must take the wealth of the Indies with you.",

Yet, as these efforts failed, with a lingering hope in the buckle's worth, he even planned going West with it as a salesman, but was soon forced to abandon that plan. And so, trying to whistle to keep up his courage, he told himself that it was not money and time lost, since he had cut his eye teeth now, and would not thus be caught again. At length, all other avenues seeming closed, shutting his eyes to the last glimmer of hope concerning the buckle, he "buckled down" to school-teaching again.

This time he hired out in East Orange, at wages of fifty dollars a month, his spirits rising with something definite again in view, and with leisure once more to pursue his studies. The nearness to New York City was another advantage; he promised himself an occasional trip there to hear Chapin, Beecher, and Everett. On the whole it was a disheartening winter our young friend spent in teaching that East Orange school. He was forlorn and lonely, living in a boarding-house, yet longing for a home. Though already two years married, the young couple had not begun housekeeping, the more practical wife foreseeing difficulties which seemed unsurmountable to her, though made light of by her sanguine spouse. 


\section{8 JOHN BURROUGHS-BOY AND MAN}

We sympathize with that earnest, aspiring youth as he unburdens his heart in a letter of that period:

... Oh, why is it that trouble and disappointment are the inevitable result of our earthly condition! I look at the stars, I look at the setting sun, I look toward the blue horizon, I ramble through the busy city, I search my own heart, I delve into the sea of books, I struggle with the mysteries of eternity, and nothing satisfactory can I find. All is a sliding sand-bank beneath me. Peace, Beauty, Satisfaction, Rest-where, oh, where can ye be found? . . .

But this is only a mood. Optimism, a practical and forceful handling of details, a sweeping away of trivial objections, and the young couple are soon cosily settled in a little three-room apartment in the suburbs of Newark; the young man walking daily the few miles to his school in East Orange, the tedious grind of teaching supplanting his visions of wealth, now vanished into thin air. Youth and hope are his companions and the sun again shines on his path.

But clouds soon loomed on the horizon which grew bigger and bigger; and those dark clouds over our student's fortunes were but miniatures of the huge black clouds that had long been gathering over the fortunes of the nation.

In the fall of 1859 the raid at Harper's Ferry had taken place. John Brown had been tried and hanged. Henceforth, swift and sinister were the events moving on to the disruption of the Union.

The young nation in its period of storm and stress was typified, in a way, in the checkered career of our struggling, aspiring youth, beset by foes without and within, struggling against an ignoble servitude, fighting desperately for the rights of personal liberty, a definite goal ever in view, yet apparently lost sight of in the indecisions, the 
compromises, the retrogressions, the countless hampering conditions, that continually thwarted him. With a nation, and an individual, the same holds true: a house divided against itself cannot stand. Half-measures are broken reeds. Before harmony, union, and progress can reign, aims must be unified, rebellions quelled, sacrifices undergone, burdens shouldered, unforgettable losses sustained. Experiments, compromises, humiliations, trials, defeats, victories, victories, defeats, crushing sorrows, and long, long months and years of persistent, heroic effort must be endured before soul, or nation, can reach that goal where victory and union, one and inseparable, are assured, and emancipation accomplished; leaving the aspiring soul, or the nation, free at last to work out its innate destiny.

The cloud looming over our student's fortunes at this time was that almost forgotten note of Dr. S-'s which then fell due. It had to be paid, and the Doctor looked to him to pay it, who, alas! had no money. As the Doctor had not kept his part of the agreement, his young partner in the deal naively wrote him that he would have to meet the note, and wait for him to pay his share when he could.

Again he tried to realize something on the buckles which he had on hand, but in vain. He became more and more worried as the Doctor kept pressing the matter, insisting that he borrow money from his father-in-law to pay the note.

One day just as he was fast sinking into the Slough of Despond over it all, a letter came which boosted his spirits mightily: A stranger from Rondout wrote inquiring about the new buckle of which he had heard, intimat- 
ing that he would like to see the owner of it with a view to buying it. Would the owner please come to New York and talk the matter over? Eagerly young Burroughs hurried there, only to learn that it was a sharp game of the Doctor's to get him out of the State of New Jersey and into New York, to arrest him. The stranger on meeting him bluntly informed him he had come to take him to Kingston, unless he would borrow money and pay the note immediately.

This he refused to do, and gave himself up, being too "green" to ask to see the man's warrant. (He had no warrant; it was a bogus arrest, though he knew it not.)

The stranger granted him permission to call on a relative in the city, but stuck to him closer than a brother the while. Through the relative he sent word to his young wife why he would be unable to return home that night then, boarding the Baldwin, on the night trip en route for Kingston, captor and captive engaged their berths and went to bed, one to revel in his easy conquest, the other to lie there and search vainly for a solution of the fastgathering difficulties.

During the night, when the boat stopped at Newburgh, the perturbed young man, seeing no other way out of his difficulties, quietly dressed and went ashore, while he who was supposed to have him under arrest calmly slept on until the boat reached Rondout in the morning. I wonder which felt the more sheepish that morning-the outwitted captor, or the uneasy fugitive. The latter hung around Washington's Headquarters all that day, thinking it an unlikely place for the constable to seek him, and at night took the boat back to New York, whence he hastened to New Jersey to explain matters to his anxious wife. 
The Doctor pursued him no further, even though he subsequently returned to his native state to live.

"It wasn't a very creditable performance," he confessed years later. "It is the only business transaction in my life that gives me discomfort when I think of it. I have always regretted that I did not pay the Doctor when I got able, though it could not have been till several years after. I paid back Father North, in small amounts, as I could. I was very green then, and, besides, my moral sense was not as acute as it is now."

One of the pleasant events of that winter in East Orange was Bayard Taylor's lecture on Humboldt, at the solicitation of our school-teacher and a friend of his, Horace Fish. To hear the lecture was their main object but incidentally they hoped to make something out of it. Burroughs and Fish hired a hall, and took in tickets at the door. There was a fair audience, but as the admission fee was only ten cents, after expenses were paid they had made but seventy-five cents apiece.

The most valuable experience growing out of that sojourn in East Orange was the friendship between Burroughs and a young man, a little his senior, E. M. Allen. It came about in this way: The members of a debatingclub in Newark, of which Allen was a member, challenged those of the East Orange club to a debate. Young Burroughs was one of the East Orange speakers, and, for some reason, surpassed himself that night, speaking with unwonted force and eloquence, so much so as to win the admiration and friendship of the ardent and magnanimous Allen, for the Orangemen defeated the Newarkians gloriously.

This friendship was destined to have a far-reaching 
influence on the subsequent career of our student-teacher. Allen was of a winsome nature, cheery, witty, versatile and companionable - the first real comrade in the life of one in whom comradeship has played so big a part. He was apt in many ways, could write poetry and stories, make clever caricatures, was a born mimic, a racy raconteur, was at home on the lecture platform, and, later, developed a good deal of business ability, though at that time was eking out a precarious living as versifier, lecturer, and whatnot. "Coffee and Cakes" and "The City and City Life" were clever, whimsical lectures with which he invariably won the friendliness of his audiences, though winning little else besides.

That summer on returning to the home-farm to work in haying, Burroughs invited Allen to visit him, and together the friends made their first camping-trip, of which we shall hear later. It was Allen to whom the first verses John Burroughs ever wrote were addressed,* and it was Allen who, when they were on a nutting excursion in 1861, carried with him a curious-looking volume of verse from which he read aloud to his companion - the first introduction of John Burroughs to the poems of Walt Whitman.

Having convinced himself that a business career was not for him, the school-teacher now turned earnestly to writing in all his spare hours, sending short pieces to the Saturday Press, using the pen-name, All Souls, and heading his articles with the absurd title, "Fragments from the Table of an Intellectual Epicure." He now says the title sets his teeth on edge. He only asked a dollar apiece for those wares, but the editor could not afford to pay

* “To E. M. A."-published in 1860 in the Saturday Press, of New York. 
even that, though gladly using the contributions. Philosophical in trend, they show him beginning to go to Nature for illustrations, as well as tracing the likeness of facts in the everyday life about him to intellectual and moral truths. They also show him observing accurately and thinking independently, and with a tone surprisingly sure for a youth of twenty-three.

Other youths, I think, will like to read a fragment from one of those early essays, "A Thought on Culture"-the first published one to bear the signature of J. Burroughs:

The end of knowledge is not that a man may appear learned, any more than the end of eating is that a man may seem to have a full stomach; but the end of it is that a man may be wise, see and understand things as they are; be able to adjust himself to the universe in which he is placed, and judge and reason with the celerity of instinct, and that without any conscious exercise of his knowledge. When we feel the food we have eaten, something is wrong; so when a man is forever conscious of his learning, he has not digested it, and it is an encumbrance.

As the spring term drew to its close, the would-be writer's ambitious young wife returned to the charge of a business career for her husband. Vaguely recognizing his mental power, she could not see why he would not apply it to something that "would count." Other men with far less ability made money, had handsome houses, lived in fine style, had a prosperous business-why couldn't he? What were his brains for, if he got nowhere with them?

Accordingly, arranging for her to go to his father's home in the Catskills, where he fervently longed to go, he stayed on near New York, looking into first one thing, then another, as a business opening. Perhaps he could get into something, and, after a while, still find time to write. $\mathrm{He}$ would try again. 


\section{JOHN BURROUGHS-BOY AND MAN}

Answering advertisements, he sometimes found two hundred applicants ahead of him, many of them skilled in the particular work they sought, while he had only inexperience to offer. He worked for some time as a draughtsman in a carriage factory, spending two days and nights on some drawings, only to find that they did not suit. Hungering and thirsting for the country, he still hung on, looking for an opening, leaving no stone unturned-a sorry time of discouragement and gloom. Glimmerings of hope, like fireflies in the dark, led him on many a long, fruitless chase. At last, acknowledging defeat, and abandoning the quest, he fled to the mountains.

The clouds overhanging the nation were lowering ominously now. Jeff Davis had introduced into the Senate resolutions containing demands which the North would not stand: the Fugitive Slave Law, long evaded by the North, must be respected, likewise the Dred Scott Decision. Lincoln's memorable speech in New York at Cooper Union had shortly followed, with its ringing declaration that right alone makes might-the speech which ultimately led to his candidacy and election as president.

A rift in the cloud of our hero's fortunes came about this time: An essay of his was printed in the Saturday Press as a leading article; the New York Independent published a poem ("Loss and Gain"); Allen was writing him most encouragingly concerning the things he was sending on to him now and then for appreciation and criticism, and offering to try to find a market for them.

The perturbed young man had at last reached the point in his career when he realized he must listen no longer to others, but to the inner voice. There was a particular 
work for him, and that he must do. Already he felt the power, and was beginning to feel a surety as to what the work was. He was willing to serve long and faithfully to attain his ends. This decision was the first real stroke in the long battle.

That summer on the old home farm he worked at whatever offered, planting corn and potatoes, working in the haying, reading Combe's Constitution of Man, and Schlegel's Philosophy of History, practicing at writing, trouting, helping at barn-raisings, and, for a brief time, camping with Allen on the Beaverkill.

Others looking on at the serious-minded youth whose worldly prospects were so dubious, thought he was getting nowhere, but he knew, though vaguely, that he was working toward the definite, though distant, goal. At odd times that summer, rainy days when there was a good excuse for stopping work on the farm, he shut himself away in the south bedroom, and nibbled at his pen, writing some, and musing a good deal. Finally there resulted an essay which he named "Expression" (though most any other title would have suited it as well). It was a philosophical affair. In trepidation he sent this to the Atlantic Monthly, and returned to his potato-digging and other tasks.

James Russell Lowell, the editor of the Atlantic, read the essay. It sounded suspiciously like things he had read over a far more illustrious signature. Who is this John Burroughs? Has he been pilfering from our Concord Sage? Surely those sentences are turned as only Emerson turns them. The puzzled editor searched through all the published writings of Emerson, but finding no trace of "Expression" there, accepted it, congratulating himself on having discovered a new and forceful writer. 


\section{JOHN BURROUGHS-BOY AND MAN}

Imagine the feelings of John Burroughs when that letter of acceptance of Lowell's reached him! His faith in himself was at last justified! It stimulated him to further and better efforts. But how could he wait for the appearance of that essay until the November number? Yet wait he must, and meanwhile - to work!-other things were seething within him, clamouring for expression.

Henceforth, articles and verses slowly gained acceptance, though they brought little or no money. So, even with the cheering recognition from the Atlantic editor, the future was not exactly rosy. No one but his friend Allen cared a four-pence that a paltry essay of his had been accepted. He was failing in what those nearest him counted success. His writing was looked upon as a kind of lazy self-indulgence, and he was continually blamed for not having succeeded in getting into business and "being somebody."

Having definitely put the business proposition behind him, however, and being sorely in need of funds, he was forced into teaching again. This time it was at Marlboroon-the-Hudson, but reading and writing were henceforth absorbing more and more time and thought. One wonders how his pupils fared, yet he seems to have given satisfaction, for he taught there from the fall of 1860 till the end of the spring term in 1862, his wife teaching with him a part of the time, taking charge of the smaller pupils. In the raspberry season they supplemented their earnings by picking berries at a cent a cup. Young Allen, hard up also, came and picked berries with them; they were the large luscious Belgium berries, called Antwerps, which no one sees any more. By great diligence, in vacation, they could each make between a dollar and a dollar and a half 
a day at picking berries, and every dollar, nay, every cent, counted in those troublous times.

Fort Sumter had been fired on more than three months before. The North had instantly rallied to Lincoln's call for troops, and with the cry "On to Richmond!" was eager to show the South how quickly the rebellion could be quelled. But the North, though optimistic, was unprepared. One hot July day, while picking Antwerps, the young couple were filled with dismay when a neighbour passing by announced the news of the defeat at Bull Run. They probably went on picking Antwerps, but with anxious fears and premonitions of what this disaster would mean.

Those were the days when the Atlantic Monthly was the teacher-student's university. He was always so eager for it that he used to dispatch one of the boys to the Post Office in school hours, and when he went himself, he could not keep from running on nearing the Office.

To go back a little, to the fall of 1860: After the proof of "Expression" had been sent to its author for correction, and returned, he knew the article would shortly appear. When it was time for the November Atlantic, unable to wait for his copy to come in the mail, he had rowed across the river to Poughkeepsie and tried in vain in two book stores for a copy. One bookseller had had a few copies but had sold them: "Did you look at the table of contents?" excitedly inquired the disappointed customer, then, suddenly realizing that the man had no interest in his essay, he mumbled something and hurried out of the shop. There was nothing to do but row back home and wait for the magazine to come in the usual way. 
The eagerness with which he opened the November number and saw his essay in that much-prized magazinewell, you must imagine it! And the check for thirty dollars which came in payment for the same! Never since earning his first twelve silver quarters by peddling maplesugar had money looked so good to him! The sum seemed positively munificent, and not to him alone-when he went to the school trustee, requesting him to cash the check, the man looked so mystified at his having all that money that the young essayist felt bound to explain how he came by it. The explanation seemed rather to add to, than to clarify, the mystery. "I suppose he was more mystified still that anyone would pay me so much for something I had written."

In the summer of 1861 there was the usual work in the hayfield on the Catskill farm, with the reading of Carlyle's French Revolution, and of the Count of Monte Christo for relaxation, and of course the inevitable "scribbling," as his writing was slightingly called. And there was the return to Marlboro in the fall for teaching. In those days, although he roamed the hills and woods, he had no special interest in the birds, except in game birds, which he shot without compunction, even killing the pretty little tip-ups that ran along the shore, taking them home for pot-pies! Mrs. Burroughs made delicious pot-pies. "Expression" had no sooner begun to be read than reports came to its author that it was being pretty generally attributed to Emerson. The Atlantic did not publish the names of its contributors in those days, and the various reviewers assumed (as Lowell had at first suspected) that "Expression" was from the pen of Emerson. Poole's 
Index and Hill's Rhetoric credited it to Emerson. Young Allen, then in Washington (1862), wrote of an amusing experience of his concerning the supposed authorship of the essay:

I was calling one evening on a young lady and met a gentleman at her house who seemed to be pretty well read. Among other things we discussed the Atlantic. I asked him if he had read an article in that magazine called "Expression." He said he had, and quoted portions of it.

"Do you know who wrote it?" I asked.

"Emerson," he said, with an air of one who knows what's what.

"Are you sure?"

"O, yes," he replied with emphasis.

Then I came down on him "like a wolf on the fold," and took him somewhat aback by telling him that he was mistaken. He seemed inclined to combat. I couldn't mean the essay he meant; he quoted more of it; said he read it at the time it came out, and always thought Emerson wrote it. So you see, my dear John, the Sage of Concord is reaping your laurels. Shame on the Sage!

Pleased at first at these reports, the young writer soon realized that it was a grave error to go tricked out in the manner of another, even of a great writer, and that he must be himself at all costs. If his style reeked with Emerson he would, as it were, bury his literary garments in the earth and let it extract the Emersonian musk. So putting aside his philosophical themes, he began writing about country things-haying, sugar-making, buttermaking, stone walls - things familiar to him from birth. These articles, with the general heading "From the Back Country," were published in the Saturday Press.

Almost at once he saw that this was his particular field; that here he could write from close and loving intimacy; that he had but to unpack the memories of that farm-boy he had been, and his page at once held freshness, vigour, charm. 
When as a boy he had had to drive the cows to pasture in summer, clean the stables in winter, feed the calves in the spring, milk, and sometimes even tread the dog-churn; when he had had to burn stumps, pick up stone, tend sheep, and do countless other chores on that dairy farm, little did he dream that those very things would help him to write his books, and here they were proving to be what was helping most! All through boyhood and youth he had stored away treasures without realizing it; and, after having tried to do many other and harder things, here, in these long-loved but commonplace objects and experiences, were the tools and the material for his chosen work! For years he had been all around Robin Hood's Barn to find it, and here it lay close at hand!-work unmistakably his! From that day he was happy. In writing of these familiar things he could speak his own thought, not merely say over again the thoughts of another, acquired from reading. And, strange as it might at first seem, in taking and adhering to this decision, he was more truly the disciple of Emerson, his revered master, than when he had written so in the manner of Emerson. 


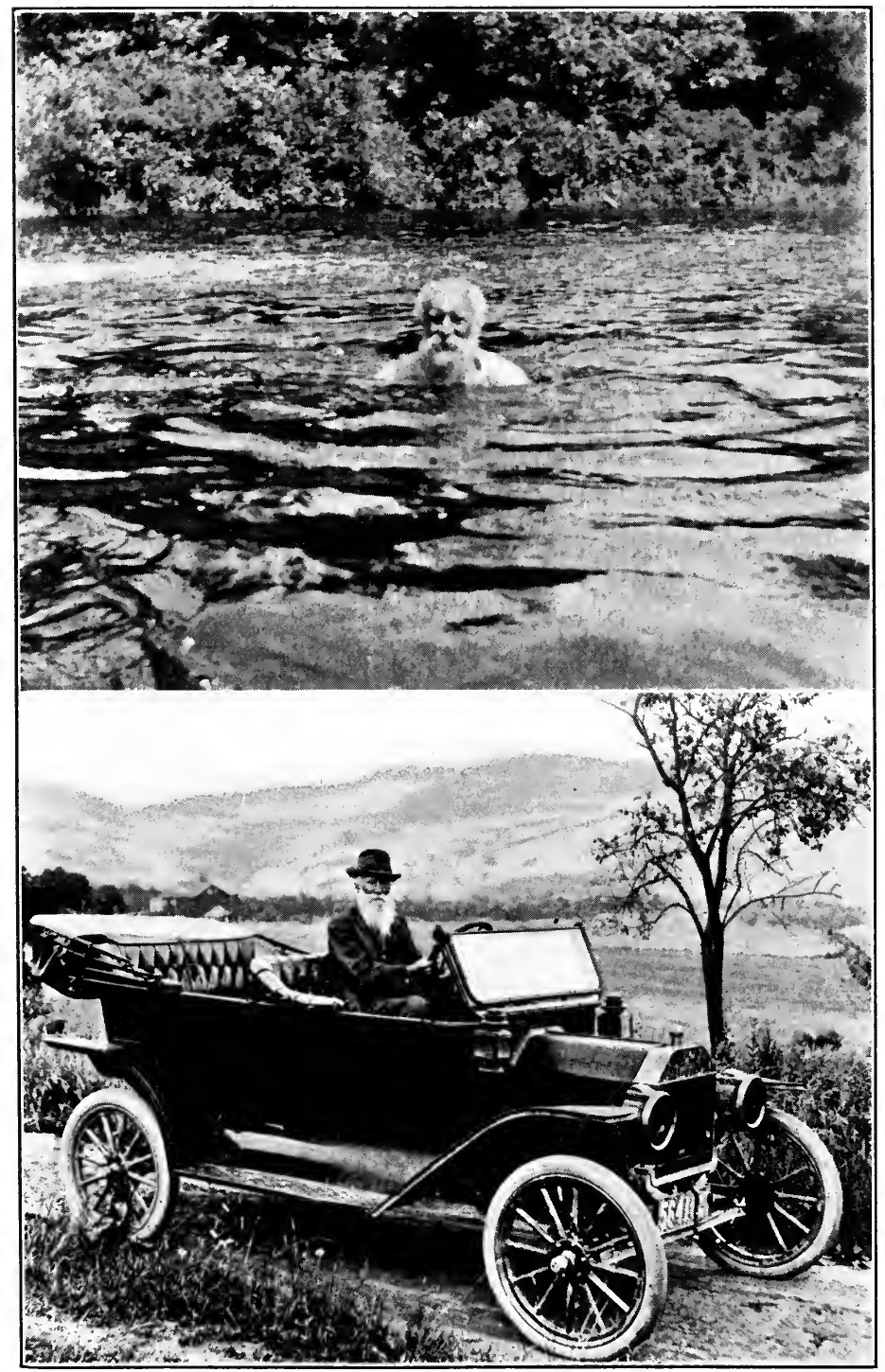

John Burroughs swimming in a mountain stream

Photo by Richard Watson Gilder

Driving his car on the farm where he drove oxen as a boy

Photo by M. H. Fannin 


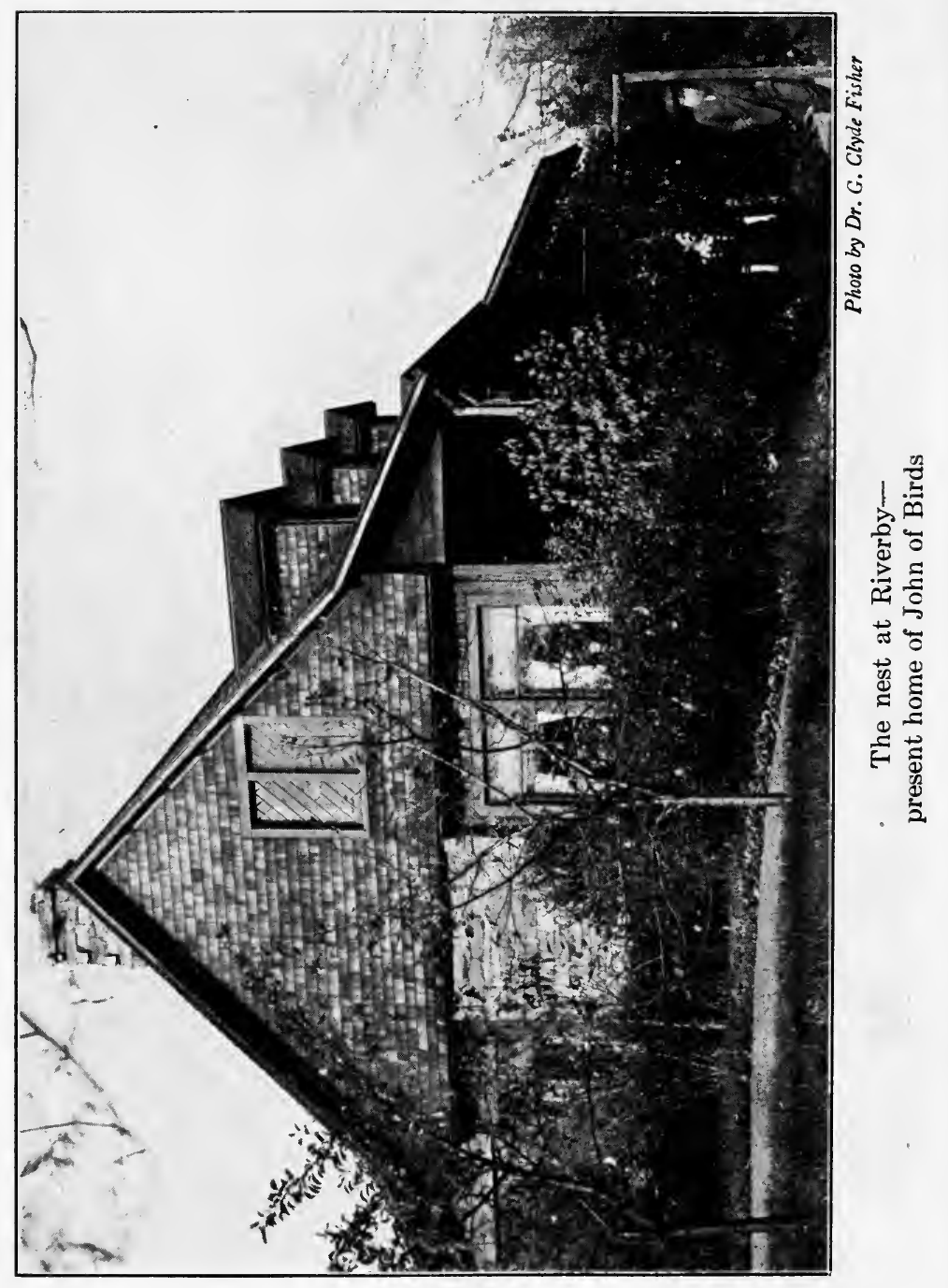




\section{CHAPTER XI}

\section{STUDENT AND TEACHER}

(1862-1863)

IN the spring of 1862, the young teacher heard of the brilliant feats of Grant at Forts Henry and Donelson; he well remembers the first pictures of him in Harper's Weekly. As no one then knew how Grant looked, and as a picture of him must be had, evidently reasoning that to have achieved what he had, he must be a giant, they represented him as over six feet tall-a fierce-looking, black-bearded hero.

John Burroughs was out in the fields at the Old Home boiling sap those early April days of 1862 when he saw a neighbour, John Smith, coming rapidly across the fields through the deep snow. Jumping his horse over the fences, Smith rushed up and announced the news of the Battle of Shiloh, the terrific losses of the Confederates, and the death of their gallant General Johnston. The sap-boiling and other farm work continued, but an undercurrent of unrest, to which letters from Allen (in Washington) contributed, was bearing our young friend on toward more eventful times and scenes.

Allen urged Burroughs to come on there and make his fortune; all it needed, he declared, was that one should be active, shrewd, and impudent. He suggested that until something better offered, he come and, with carpet-bag full of necessary articles for the soldiers, make frequent 
journeys to the nearby camps, supplying the boys with things not carried by the sutlers.

To the would-be writer this huckstering did not appeal, and so he wrote his friend, who lectured him mildly for his pride, pointing out that many men he knew in exalted social positions were condescending to do that very thing. Though not impressed with this, Burroughs did have a longing to get near the scene of action, even to take a hand at soldiering; his wife's dependency upon him, however, gave him pause.

Allen wrote of hearing Emerson lecture, and Artemus Ward; of the interesting people he was meeting; of the stirring scenes in the streets, the marching men, the officers in their splendid uniforms, the lines of white-covered baggage wagons, and an occasional band of rebel soldiers being marched through the busy streets. He expatiated on the high cost of living- "You cannot get board for less than six dollars a week!" [sic!] But assuring his friend that, even at that, he was prospering for the first time in years, he urged him to bestir himself, to hasten there and look for work, and stay no longer in the country to vegetate:

You must have active life; that keeps the channels of the brain unclogged. You'll get to be a cabbage if you stop long in the rural districts. You ought to be here where you can see Art and human nature. ...

And he urged John to come for his [Allen's] sake also:

I need you to be my intellectual poker, to stir up my mental grate, create a draught, and make the sparks fly. The fire is smouldering. I am afraid it will go out.

The letters from Washington came frequently to the worker on that dairy farm in the Catskills, grubbing away 
at seventy-five cents a day, besides making some agricultural ventures on his own account. If not in danger of turning into a cabbage, as his friend feared, he was at least turning to onions for a season: he tried to raise some on a little patch of ground allotted him, to reap only regrets and disappointment. The crop proved a failure, not one in a hundred coming up, and the seed had cost him a sum he could ill afford. The venture was a severe blow to him, and brought down severer criticism on his head.

Here are some extracts from Allen's letters of that period:

February 28, 1862

I dash you off another hasty note to let you know of the Army movements here .... the papers are forbidden to publish anything with regard to military movements under pain of suppression. . . .

Great events hover, and soon you will hear of a decisive conflict. The Great Advance is commencing, in fact, has already commenced.

Night before last and yesterday thousands of troops marched quietly through the streets to the depot on their way to the upper Potomac. Gen'l. McClellan has already gone up to Banks's column with ten of his aides. Yesterday one of his staff was in the store and bought rubber and wool blankets and other camp equipments.

The whole army is under marching orders and expects to move at any hour. ... An officer in the Regular Army told me to-day that he and the other officers would have to carry their own baggage, an unusual thing for officers. Every man is to carry three days' ration in his haversack. Some of them think they will move toward Occoquan and attack the right wing of the rebels, while Banks hammers away on their left. The officers don't know themselves, only surmise. Banks crossed the river three days ago, and I have no doubt is fighting now. This morning about fifty ambulances went down the avenue on a run. They were terribly suggestive of mangled men, and blood, and dying groans.

There are two hundred thousand armed men here on the banks of the Potomac, exclusive of Banks's and Wool's divisions. It is one of the finest armies the world ever saw, composed of men, hardy, true, and brave, well drilled and well equipped. They have been longing for action for some time and now are jubilant at the prospect of a battle. They will strike 


\section{JOHN BURROUGHS-BOY AND MAN}

blows that will make the traitors quail. The rebel rascals will be unearthed at Manassas, and if our boys get them in the open field, God help them!

I hear this afternoon that about a hundred secessionists have been arrested at Alexandria, and now are in the old Capitol prison. They are all spotted in that city and will be summarily dealt with. . . .

March 6, 1862

. . . I am sorry I have no place ready for you yet. . . . About two months ago we started a store in Alexandria, and if you had been on the spot you might have had a chance to conduct it, but it was necessary to have a man immediately. ... .

As for the Army, John, don't think of it. It is a miserable life. Officer's life is bad enough, but a private's life is terrible. Mud, slush, hunger, cold, toil, typhoid fever, measles, small pox, is what he has to go through with. But worse than that is the ennui superimposed by inactivity and confinement in camp. A private has got to herd with all sorts of men, sixteen in a tent. He loses all individuality, and becomes a mere machine to be ordered hither and thither at the will of some upstart to whom, often, he is far superior in intellect and social position. A position on some General's staff is about the only active military position I would like, but first seats in the kingdom of heaven are about as easy to get as that. Every government position comes through favouritism. As for an office in the regular army, that is equally hard to obtain. I have a number of friends in the army of all ranks, from lieutenants to Brigade Officers, and although they look very fine on the streets in their uniforms, they lead a rough life. So give up the idea of soldiering. I'll keep my eyes open for you here. . . .

While I write I hear the sound of music. It is the funeral of the brave old General Lander passing down the avenue. I drop my pen to see the procession. . . . It was a beautiful sight. The procession was not long, some two or three thousand men, but they looked fine. First came a regiment of infantry marching with their arms reversed and treading slowly to the mournful music, the platoons reaching across the breadth of the avenue. The men looked finely in their dark blue suits. Then came an artillery company, the men mounted and gay with scarlet braid and plumes; then a squadron of lancers with gay pennons flaunting from their lances. Then a caisson with the coffin upon it shrouded in the Stars and Stripes. The dead warrior's horse, a beautiful creature, was led behind the caisson, the whole surrounded by a number of stalwart 
sharp-shooters, with their telescopic rifles on their shoulders. Then came carriages with McClellan, McDowell, and other distinguished militaires. Lastly another regiment of infantry. These are no Sunday soldiers, but fighting men who have seen battles and expect before another week is gone to see them again. . . .

You should see some of the regiments marching in a storm just at nightfall, the men shuffling along with great knapsacks on their backs, their trousers tucked in their boots, covered with mud and soaked with rain. It would take all the romance out of you. Sometimes they have to lie down in the mud after a day's march, and sleep in the rain. Their tents are often pitched where the mud is six inches deep-worse than our Beaverkill experience.

The preparations for an advance are still going on. . . .

I wish you were here, you would get some good ideas and might write some telling things about war and philosophy. . . .

May 1, 1862

MY DEAR JOHN,

If you were here now I should be happy, for you are my twin-spirit. We are like two lovers, are we not? Do you remember how we used to lie on the rock by the brook in the twilight? You ought to be a woman, John, or I. In this soft, sweet air of spring, when the bloom of the peach tree, and the white blossoms of the other trees are snowed down on the grass, and the golden stars of the dandelions shine out in green nooks, and sweet earthy scents fill the air, I seem to see your spirit in all these things. You are so associated in memory with the spring and summer, your nice observation of the phenomena of nature, and your fine appreciation of the Beautiful as it is gradually unfolded over the hills and valleys, has so identified you in my mind with these sweet seasons, that I cannot help thinking of you when I feel the dreamy influences of spring, and long to be with you. I imagine you exclaiming to yourself at this point, "Why Allen has made a mistake in directing this to me-it is a love letter to some fair friend of his!"

Even if I had not got your letter the other day I should have written just the same, for I know, my dear boy, that you are out of the world of men, and I am among the busy things, hearing and seeing much that would interest you. ....

. . . I'll have to knock down your theory of McClellan going to Fredericksburg. ... There are no signs of our forces leaving the Peninsula. Our intrenchments are thrown up within six hundred yards of the enemy's works. A new regiment of French Zouaves, called 


\section{JOHN BURROUGHS-BOY AND MAN}

Les Enfants Perdus, marched through the avenue to-day on their way to Yorktown. They looked finely in their picturesque uniforms with their Enfield rifles and bright sabre-bayonets.

I was talking this afternoon with a chaplain who came to-day from Fiedericksburg. He says our force there is thirty thousand. We do not occupy the town but are encamped on the heights opposite. Pontoon bridges are being built so the whole force can be thrown over at once. Our soldiers are not allowed to go over, for if they did, they would certainly pillage, as for the past few weeks they have had a hard time of it, and are deprived of many comforts and even necessities. There seems to be a desire on the part of the commanders to conduct the War in such a manner that no charges of outrageous conduct may be laid to our soldiers.

The holding of the town is of little consequence, so long as we command it . . . if the Stars and Stripes were raised there, the rebels who are in sight of the hills opposite would shell the place and cause a fearful waste of life and property, so it is out of mercy to the inhabitants that the town is let alone, but when we are ready, down comes their flag!

General McDowell occupies the fine mansion of a Mrs. L-, who went across the river to get away from the detested "Hessians." She sent her coloured woman over tothe General with the request that the playing of Yankee Doodle be discontinued as it was very distasteful to her ear. It is needless to say that the melody was more prevalent than ever.

I met Gen. McDowell with three of his aides on the avenue Sunday afternoon, taking terrific strides, their sabres clanking loudly on the sidewalk. They looked somewhat dilapidated, evidently just from the field. The General is a noble-looking fellow, tall and broad-chested, with a bronzed face and a nose that looks as if it had been struck across the bridge with a club. He has a square forehead, and a very pleasing expression. I am told he is a very courtly gentleman. I saw him catch his spurs in a lady's dress one day and come near falling, but he recovered himself very gracefully and begged the lady's pardon.

The other Mac, the "little George," is a very different-looking person. He looks like a well-to-do butcher-boy, the kind that "kills for Keyser, and can whip his weight in bull-dogs." He is short and thickset, with a beefy face and bull neck. His pictures give an impression of dark eyes, eyebrows, and moustache; on the contrary, they are all light. I stood beside him at the President's reception one evening and observed him well. He seemed very diffident and wished to avoid the gaze of the many eager eyes fixed upon him. It was with difficulty his lady friends induced him to take a promenade through the East Room, and he got 
away as soon as possible. I saw him a short time after in the little Reception room talking with some friends near the President, who was pumping the hands of his visitors in a very jovial manner. The President, seeing the people hurrying by him, turned to see the cause. "Ah! General," said he, "are you here?" And the tall, good-natured Abe put his arm around the short, quiet George, saying, "Come, General, step up in line, they all want to see you." "George" shook hands for a short time, but soon retired and I saw him afterward in a remote corner talking with Cameron.

Our good President is the homeliest and the best-natured looking man I ever saw. There is something so kindly about his face that I like to look at him. He looks awkward in white gloves and a dress coat, and you would laugh to see him do the "extensive" with the ladies. He was missed a short time, and while walking through one of the halls, I saw him emerge from a door and make his way back to the Reception room with a peculiar sliding step, keeping close to the wall. He looked very funny. A short time after a lady friend was talking to him and I heard the word "boots" mentioned. I looked down and saw that he had on slippers. The poor man had been suffering the pangs of purgatory in tight boots. . . .

Mrs. Lincoln is as round as a dumpling and dresses gorgeously, in low-necked dresses, showing very plump shoulders. . . . She looks as if she made the excellent Abe stand around. . . .

I saw John Hay, the author of "Ellsworth" in the Atlantic, on the street the other day; he is the President's private secretary. . . .

Since I read that poem of Gen'l Lander's I have thought tenderly of the man. Calling at a friend's house the other evening where he often visited, I saw a photograph of him taken on the prairie. There he stood on the trampled grass, the vast prairie stretching away to the horizon behind him. He was dressed in hunting costume, leaning on his rifle. It was a noble form and face, tall and erect, his slouched hat thrown back from his high forehead, his dark eyes beaming large and full, a Grecian nose and Oriental beard. . . . He was brave and true, and, from his poem, full of tenderness. But I am told he seemed rough sometimes, and cursed frequently. . . . I wish I had known him. . . . Fitz James O'Brien, his aide, is dead, too. I am sorry, for he was a poet. If it were not for my mother and sister I think I should throw my little life in the breach against our country's foes. I think sometimes that I would like to slip out of this life ... to free the spirit which is chafing this body. It is unmanly, I know, but you feel so sometimes, do you not, my dear friend? 


\section{JOHN BURROUGHS-BOY AND MAN}

Then, commenting on his friend's clouded skies, he concludes:

. . . Forward, my dear friend! you will yet be heard in the land! Slow and sure, like Emerson, Hawthorne, and all true geniuses, you will reach the heights. ...

Little wonder that young Burroughs's war fever ran high that summer and fall, with such letters as these, together with the delays and disappointments connected with the Army on the Potomac, and the talk of drafting to take place. After Pope's defeat at the second battle of Bull Run, John Burroughs wrote his wife, away on a visit, that it was time every man, married or single, shouldered a musket; that unless she returned home soon, she was likely to find him gone to join the Delaware Blues; that he would wait and earn what he could in the oats, so as to leave her as much money as possible; that she could stay with his people untill he returned, and have a pension if he never came back.

How often it happens in real life that prosaic circumstances intervene to block one's worthiest endeavours, and mock his most heroic moods! An enemy in ambush, shortly after that, prevented the translation of our hero's martial feelings into action: A series of carbuncles attacked him in relays, not only preventing him from working effectually in the oats, as planned, but also from joining the Delaware Blues.

Among a series of articles "From the Back Country," which our essayist wrote that summer for the New York Leader, was one, "Harvest Time," for which the editors could give no money, but for which they sent him, in payment, a pass for three years on the Ulster and Delaware Railway. But that article brought him something far 
more precious than money or fame-the friendship of Myron B. Benton, a young man a few years his senior, a rural philosopher and poet, an advanced farmer, a man of ripe and refined literary taste. Attracted by these articles of the Back Countryman, that summer Mr. Benton wrote John Burroughs the first letter of appreciation he ever received from a stranger concerning his writings. Thence there developed a helpful friendship which terminated only at his death, thirty years later.

When Mr. Benton had praised the country sketches for their charm and fidelity, the essayist in reply said he only undertook them to limber up his style, adding that if Benton had chanced to see his essay, "Expression," in the Atlantic he had doubtless perceived that it travelled a little stiff, like a ring-boned horse, a fault which he found this writing on homely country things was enabling him to overcome.

A brisk correspondence ensuing, personal data were exchanged, literary likes and dislikes compared, and the conduct of the war was freely commented upon. By this time the Countryman in the Catskills was disinclined to enlist under generals in whom he had so little confidence. On September 12, 1862, a few days before McClellan stopped Lee's invasion at the bloody battle of Antietam Creek, he writes:

The war feeling runs very high with me, but I have not enlisted and probably shall not. I have lost all confidence in our generals; there is not one whom I would serve under without compulsion. McClellan I implicitly believed in once, but now consider a failure, fully as much as Pope, the Gasconade, is. "Mac" is a very proper general, a very mathematical gentleman, but, me judice, has not a spark of genius. And mark this, so long as there is only engineering skill and mathematical precision on our side, and dash and bravery and rapidity of movement 
on the part of the Rebels, so long the battle will be against us. No great war can be successfully carried on purely on mathematical principles (organizing Victory beforehand) any more than a great poem can be written solely by mastering "Parker's Aids." Forego spades and picks and the idea of digging or engineering an active, vigilant enemy out of a place, rely upon pure bravery, and the ability to deal quick, hard blows, and something may be done. Halleck engineered the enemy out of Corinth, and we now see the fruits of it! "Mac" ditto out of Yorktown, and see the harvest he gathered! Obliging an enemy to retreat without fighting him is disastrous; it is winding the spring up, and you know what effect that has-narrows its compass and in the same measure intensifies its power.

I have not read the Tribune this summer, nor the Post, so these views are not those of any newspapers. I have arrived at them solely from studying our own movements and those of the Rebels. Look at the contrast! I know it is very naughty of them to "cut up" as they have! They ought to have come up in front of Washington, or Pope's army, and gone to digging. But enough of this. You will excuse me for talking thus, for I feel deeply upon the subject.

In the light of later knowledge, and the perspective of time, this opinion of the young man of twenty-five concerning the conduct of some of the Union generals, shows that he was something more than a "cabbage head," or even a budding essayist. McClellan's failure to follow up his Antietam victory, his second removal, Burnside's reckless assault of Fredericksburg, with his awful repulse, and, in the spring (May '63), General Hooker's defeat at Chancellorsville, were causing a general disheartening, as well as a critical attitude, among loyal hearts everywhere.

Benton, in reply to the criticism concerning the conduct of the war, said, in part:

I fear that you are too nearly correct in your opinion of our officers, though I am not quite so devoid of confidence in them. We have, indeed, been out-officered from the beginning, but however bad they are, they are, of course, better than none, for in the latter case we could 
not fight at all, and fighting is our only hope now. We must stick by our officers until we, the people, compel the government to put better in their places.

It is a pity, indeed, that the Southern bull would pitch in, instead of raving at a distance, according to the policy of the Northern one, pawing and "digging entrenchments," as we often see such belligerents do on the farm. I have still confidence in Lincoln's honesty, but, 0 , how far behind the day he is! A handful of half-loyal men in the border states outweigh all the rest. It is a pity that he who once thought that no method of dealing with slavery was fit which did not contemplate it as wrong, should now hold back. Only a day or two since I heard a speaker, one of the hard old sort, who scarcely thinks the negro equal to a baboon, plead strongly for immediate emancipation.

In October the correspondents are planning for a meeting in Poughkeepsie, Benton to visit his soldier brother* in training there. The younger man, warning his friend that he is likely to be disenchanted at nearness and contact, and confessing that he is habitually stupid, his occasional bright spells almost never occurring with strangers, writes:

If I should find that I have always known you, though I have never happened to meet you before, why, we will get along first rate together.

He names a certain hotel for the place of meeting, telling his friend that if he sees a middling short, thick fellow with a mere shadow of side whiskers, dressed in a dark suit, and a light felt hat, with a newspaper clutched in his hand, coming along the street in front of the hotel, there's a chance of its being he.

And so the friends met, and got along "first rate" together. Soon after this, the "middling short, thick fellow" went to the town of Olive and speculated in a consignment of honey, but the honey got crushed in transportation-turning, as it were, to gall.

* Charles E. Benton, author of As Seen from the Ranks. 
Just what directed his thoughts to medicine he does not remember, but without abandoning in the least his intention of becoming a writer, he decided to combine with this the study of medicine. Accordingly, he began reading anatomy in the office of his old friend, Dr. Hull, at Olive, and teaching the little school there, at seventeen dollars a month, his wife remaining in his father's home at Roxbury, there being no rooms for rent available there, and little of the wherewithal to rent them, had such been found.

The future looked pretty dubious but, in spite of gloomy misgivings, he must subconsciously have been sustained by a conviction of self-dependence, and a trust that the long time following the sowing would be crowned by joyous reaping; that some day his Own-whatever his soul craved and deserved-would come to him. One gloomy evening in November, as he sat in the Doctor's dingy little office with Gray's Anatomy, he suddenly pushed aside the book and began scribbling. What he wrote was the now well-known poem, "Waiting," which has probably brought him more friends than anything else that has ever come from his pen. He thought little of it himself and the poem made but little stir at the time. It was not printed till two years later, in Knickerbocker's Magazine. For years it seemed completely forgotten until Whittier, resurrecting it, included it in his Songs of Three Centuries. This seemed to give it vogue and it has travelled on the wings of public print ever since.

The reading of medicine continued, but hearing of a school at Buttermilk Falls (now Highland Falls) near West Point which needed a teacher and would pay better wages than the Olive school, he resigned in December, took along his medical books, and began teaching in the 
little river town. Again the couple set up housekeeping, and again the skies brightened for a little. Besides reading medicine, for "side dishes" there were Dickens's Great Expectations, and Prescott's Conquest of Peru.

Before many months had passed, however, he abandoned the thought of becoming a physician, the fine library to which he had access at the West Point Academy probably proving too powerful a rival to the few medical books he had borrowed of Dr. Hull.

On the 18th of December, after Burnside's repulse, Benton writes:

$\mathrm{Oh}$, this last repulse and slaughter of our army! When are we going to accomplish anything? The only morsel of encouragement there is in it is that we have a general who will attempt something at least. My brother is still in Baltimore-it is quite probable that the regiment will remain there this winter.

Knickerbocker's Magazine accepted a paper that winter on "Analogy," giving the essayist Wilkinson's Human Body in payment. His friend, Henry Abbey, a poet, declared the essay "brilliant," but the Evening Post pronounced it "heavy," and the sane young writer, in a letter to Benton, agreed with the judgment of the Post rather than the poet. He complained to Benton that he had not written much for some time, had "merely cackled without laying an egg."

That school at Buttermilk Falls was a hard one to govern, the boys being very unruly. One day when a certain lad became insolent, the impulsive teacher, losing his temper, "walloped" him severely. In the ensuing struggle the teacher finally got the upper hand; but so heartily ashamed of himself was he for losing his temper that he stood up before the school and, breaking in two the whips, 


\section{JOHN BURROUGHS-BOY AND MAN}

told his pupils that if he could not keep school without such scenes as that, he would quit; he was not there to thrash them, he said, but to help them. Admitting contritely his own weakness, before he had finished he was weeping, and his pupils were weeping with him. Thereafter obedience and harmony reigned.

In January of 1863 , and for months following, the tide in the fortunes of the Union cause was at its lowest ebb; the Burroughs-Benton correspondence reflects those anxious times. Benton's remark shortly after the Emancipation Proclamation shows how the immortal Lincoln was criticised and carped at even by men as fair-minded as this level-headed young man. Because the memorable document could not accomplish everything desired, the fact that it liberated three and one half million slaves earned for it only the "faint praise" of these words to his friend Burroughs:

Thank the Lord we have the long awaited Proclamation at last; though it comes, like Samson, shorn of its locks of strength.

The slaves were freed at last; but, to continue the parallel in the fortunes of our youth and the nation, the schoolteacher of Buttermilk Falls found himself in bondage for the first four months of that momentous year, his writing and meditation being practically suspended, owing to the semi-invalidism of his wife. A wearisome round of household duties, nursing, and teaching was his portion, until her convalescence in May, and the too-long-delayed arrival of a housemaid upon the scene.

An acquaintance with Professor Eddy, a scholarly man and a botanist living at Buttermilk Falls, resulted at this period in long walks in the woods, the botanist initiating 
him in the study of the early wild flowers. From now on his letters give glimpses of the ardour of these quests; the discussions concerning McClellan and "Fighting Joe" and Burnside are superseded by bloodless conquests of his own in the May woods, the letters breathing the fragrance of arbutus, revealing the tender grace of hepatica, corydalis, and claytoria, and announcing his delight in gathering cypripediums.

It was, in truth, a peaceful life he was living those months in the midst of war's alarms. One day at noon on going home from school and stepping into his bedroom, he was startled to find a quail sitting on his bed, the bird evidently having flown there to escape a hawk. Trivial as is this incident, it stands out in his memory as clearly as much more significant things in that far-away period.

But letters from Allen will not long allow the war to be forgotten. In early May, Allen writes:

I have seen several officers and others within the last few hours, just up from the front, and they all report that Hooker has crossed the river again. He'll hop on their breast-bones before they know it and be picking the meat off. Now while I write I hear the rattle of ambulances bringing the wounded in, and so they'll rattle all night. . . .

From now on Allen's letters begin to mention Walt Whitman, who saunters into the store occasionally:

... a broad-chested old fellow with grey beard and moustache radiating from a broad, ruddy face. He has the mildest of clear blue eyes, far apart, and one of the most sympathetic voices I ever heard in a man. He wears a broad-brimmed, soft hat well back on his head, and collar well open on the chest. His dress and air are very farmer-like, and he walks the streets with an easy stride, his hands in his pockets, and always seems to be musing. He does not talk much on literature. He lent me some letters from some of his young friends in New York. They call him "Walt," and by reading you would judge him to be a 


\section{JOHN BURROUGHS-BOY AND MAN}

young fellow, and, indeed, he is young, with his perfect health and youthful tastes.

Later in the month:

Walt was in the other day and I had quite a talk with him. He has a volume coming out soon called Drum Taps. . . .

June 18, 1863:

Walt just passed with his arms full of bottles and lemons, going to some hospital, he said, to give the boys a good time. . . .

Still later:

Walt is much interested in you. I sketched your history some to him. He would like to know you. He is a good fellow, and, although over fifty,* belongs to the present generation. He was much interested in our trip to the Beaverkill, which I detailed to him.

\section{Later still:}

He [Whitman], good man, was just returning from some hospital where he had been doing that sort of good which a kind heart and noble soul can do-performing those sweet, balmy ministrations which win the sinking spirit from the very borders of the Dark Realm, his large active sympathy reaching down to the homesick soul, shivering within a shattered body, and lifting it into light, and warmth and love.

One June day as John Burroughs was sauntering around West Point when the official visitors were there for the examination of the cadets, he spied a tall, striking-looking person with a much too large silk hat pushed back on his head, and an air of eager curiosity. He wondered who the countryman was who was evidently away from home for the first time, intent on seeing all there was to be seen.

That night Myron Benton came to town, and rushing into the Burroughs home, his usual placidity considerably ruffled, announced that Emerson was over at West Point. Then Burroughs knew who the alert, eager "countryman" was.

* Whitman was only forty-four at this time. 
The next day the two friends went over to the Military Academy and met their hero, and walked and talked with him. He seemed glad to get away from the older fellows, and they followed him about much as Socrates was followed by the youthful Athenians; only, instead of the master questioning them, they did the most of the questioning. They asked him particularly about Alcott, Thoreau, and David A. Wasson, and he told them many significant things concerning those gifted friends.

That talk of Emerson's to the young men was like water to a thirsty hart. They carried his valise to the boatlanding, they hovered near as he stepped on the little ferryboat, they stood close to the boat listening to him till the last minute, and waved to him as he smiled benignly when the boat moved away.

It was a red-letter day in their lives. They had seen and touched their hero, and virtue seemed to have gone out of him into their very souls. For hours, even days, they moved in a different world. Wisdom had tarried awhile with Youth, and Youth, basking in the light of her countenance, knew itself to be blest.

The library at West Point had, from the first, been a godsend to the student-teacher, but as the books could not be taken from it, and as it was two or more miles distant from his home, and he could seldom get there except of a Saturday, it left much to be desired. But here, in May or June of 1863, he chanced upon Audubon's Birds with its spirited coloured illustrations. It was one of the most momentous happenings of his life. His enthusiasm became inflamed. It was like bringing together fire and powder. In his childhood when he had noted with such 
curiosity and delight that strange warbler in the Deacon woods, of which we have read, he had said to himself, "I shall know the birds some day," but in all the years that had followed, nothing had come of that thought and wish on his part until now; his observation of the birds and their ways had apparently been aimless; his knowledge of them unsystematized. But hear what he says of the effect which Audubon now had upon him:

I was ripe for the adventure. I had leisure; I was in a good bird country. . . . How eagerly and joyously I took up the study! It fitted in so well with my country tastes and breeding; it turned my enthusiasm as a sportsman into a new channel; it gave to my walks a new delight; it made me look upon every grove and wood as a new storehouse of possible treasures. I could go fishing or camping or picnicing now with my resources for enjoyment doubled. The first hooded warbler that I discovered and identified in a nearby bushy field one Sunday morningshall I every forget the thrill of delight it gave me?

The ardour with which he pursued this new study deepened throughout that eventful May and June, with the throng of returning birds to quicken it, and the collection of mounted birds for reference at the Military Academy. It increased as the season advanced. A new world opened up to him in the very midst of the old, almost blotting out for him the perilous fortunes of the nation. "While the Battle of Gettysburg was being fought (July 1-3) I was in the woods studying the birds-think of it!" and he sighed in deep contrition, reproaching himself for his callousness. Pickett's gallant charge, the withering fire of the Union guns, immortal heroism in both attack and defence, and then the wavering line stopping, slowly bending backward, breaking-the Southern cause virtually lost!-all this taking place on the heights above Gettysburg, and the next day Lee in sorrow unspeakable retreat- 
ing to the Potomac with his defeated army, while Grant was entering Vicksburg in triumph-all this, while the bird-student was pursuing warblers in the woods around West Point!

How could this young man have been so seemingly unmoved by the fate of the Union whose welfare he unquestioningly had at heart? His own words, uttered years later, when from the summit of the years he looked back upon his life, furnish the explanation:

My life has always been more or less detached from the life about me. I have not been a hermit, but my temperament and love of solitude, and a certain constitutional timidity and shrinking from all kinds of strife, have kept me in the by-paths rather than in the great highways of life.

... I have kept apart from the strife and fever of the world, and the maelstrom of business and political life, and have sought the paths by the still waters, and in the quiet fields, and life has been sweet and wholesome to me. In my tranquil seclusion I am often on the point of upbraiding myself because I keep so aloof from the struggles and contentions ... about me.

... I was never a fighter; I fear that at times I may have been a shirker, but I have shirked one thing or one duty that I might the more heartily give myself to another. He also serves who sometimes runs away.

... I missed being a soldier in the armies of the Union during the Civil War, which was probably the greatest miss of my life. I think I had in me many of the qualities that go to the making of a good soldier -love of adventure, keenness of eye and ear, love of camp-life, ability to shift for myself, skill with the gun, and a sound constitution. But the rigidity of the military system, the iron rules, the mechanical unity and precision, the loss of the one in the many-all would have galled me terribly, though better men than I willingly, joyously, made themselves a part of the great military machine. I would have been a good scout and skirmisher, but a poor fighter in the ranks. I am a poor fighter, anyhow.

And who shall say that the service John Burroughs has rendered his country by living his own sane and contented 
life, and writing his books, has not been far greater than any he could have rendered by becoming a soldier? He has given to the whole nation a fresh, sane, simple outlook upon life; has stimulated a love for nature that has been a saving grace to young and old. As that great American, Theodore Roosevelt, said to "Dear Oom John:"

It is a good thing for our people that you have lived, and surely no man can wish to have more said of him.

Early in August of '63, Allen, Benton, and Burroughs, with one Jaspar from Jersey, planned a camping trip in the Adirondacks. Burroughs wrote Benton, burdened with the cares of a large farm in Dutchess County:

Let not trifles detain you. We will have a glorious time. Write by return mail and say you are with us. The expense will not be much, but the fun boundless.

Of that sojourn in the Adirondack wilds we read in Wake Robin. Allen, coming on from Washington, missed the stage at Poughkeepsie, walked the twenty-eight miles to Benton's home at Leedsville one hot August day, and the four then set out for two weeks of glorious freedom.

Shortly after returning to Buttermilk Falls John Burroughs wrote his first bird article.

The reluctant teacher again took up his irksome task, more irksome than ever after those free days in the forest. The pay was pitifully inadequate to meet the mounting cost of living. He asked the trustees to increase it, promising himself that unless they did, he would discontinue teaching and volunteer.

Gettysburg and Vicksburg had been the beginning of the end of the long struggle, but the end itself was not yet. Still the war news that now came to the restive teacher 
was more cheering than heretofore. Real teamwork was taking place. Buell and Rosencrans in Kentucky and Tennessee had compelled Bragg to retire to Chattanooga, Grant and Sherman, free after Vicksburg to move eastward across Mississippi and Alabama, driving Johnston before them, were working to join Rosencrans at Chattanooga and push the Confederate armies into Georgia, while the Army of the Potomac was to press down on Lee from northern Virginia. This "Anaconda" policy promised a speedy end of the Confederacy, when Bragg's sudden turn on Rosencrans at Chickamauga nearly caused a crushing defeat of the Union cause. But the magnificent defence of General Thomas almost turned defeat into victory.

The news that came of the valiant "Rock of Chickamauga" so stirred our quiet school-teacher that we find him, on the 23d of September, writing to Benton that he can no longer be satisfied to go on in that way; that he is seriously contemplating joining the army; that he craves action; and that if he only had someone like him [Benton] to go with him, he would go without delay. Lover of comrades that he was, he could not quite make up his mind to such a step without a "buddy." But already two of the younger Benton boys had gone to the war; the elder son was needed to carry on the work of the farm. Immediately from his farmer-friend comes a protest:

This matter of your going into the army troubles me not a little. God forbid that I should throw a straw in the way of patriotism now. Our country needs sacrifices which should be offered willingly; but I do not see that the cause requires very much now in the mere matter of numbers, after the means which have been taken. One born with the genius to direct and control the great mass of raw material could do something 
for his country now; but I cannot see that the demand is such that you are called upon to enlist at this time. I beg of you do not plunge into this thing out of rash uneasiness and craving for excitement. Such feelings ought to be smothered before they lead you to bury all your opportunities of intellectual improvement, as you know you would. I would not have answered to-night except to send my opinion on this subject; for I fear that you are going to be very precipitate. Think of all you would forego to satisfy this craving for the excitement of the "big war." One week would satisfy all that, and then-the long drudgery. If you think it is your duty to your country, I will not open my mouth, though it would be a sacrifice on my part to lose you. What you would sacrifice would be immense. I need not tell you that your after life will depend very much upon the way in which the next three or four years are spent-towards your development.

. . . Now I wish you in particular to drop me a line by the next mail after receiving this, and tell me your plans, will you not?

In spite of his friend's solicitude, it was not until ten days later that Burroughs wrote his friend Benton that his plans for enlisting had been "knocked prematurely in the head" by the severe illness of his wife, whose condition still prevented his leaving her. He was then again carrying on the threefold work of keeping house, nursing, and teaching school. The draft had come off in the village but he had "not the honour to be a conscript." He begged Benton if he could find a housemaid in his vicinity to kidnap her and send her along. The maid did not materialize, but the wife was soon convalescent.

In late October the school at Buttermilk Falls suddenly found itself without a teacher. On closing school one night, after having given out the lessons as usual for the next day, the teacher put the key in his pocket. He never went back. The undercurrent of protest and unrest suddenly culminated in abandonment of the school. Thus ingloriously ended his career as a teacher. He had never been able to give himself to the work. It was but a means 


\section{STUDENT AND TEACHER}

to another end, and almost before he knew it, he had quit it once for all. He had quit his various business ventures; he had abandoned the brief study of medicine; but through all these changes had steadfastly held to his serious reading and writing; and now with his absorbing interest in the birds and the flowers, and the ambition to become a writer, conditions and circumstances seemed to be focussing more clearly on that as a career-and yet, and yetthere was the War beckoning! One decision, the abandonment of teaching, had been made, but what about the other?

In late October, with the birds, he turned his back on the Highlands of the Hudson, and migrated South as far as Washington, in quest of work and adventure. 


\section{CHAPTER XII \\ WORKING FOR UNCLE SAM}

(1863-1867)

JoHN BURROUGHS was in his twenty-seventh year when he went to Washington to live. Country born and bred, and country dweller as we have seen him to be, he entered with zest upon this first real taste of city life. He had cast off the drudgery of school-teaching, and freed for a time from domestic cares, found in this new untried life strong contrasts which interested and stimulated him. And yet the very day after his arrival he fled to the woods, and during his ten years of city life fled to the woods whenever he could, which was pretty often; for in those days the dweller in Washington could get into the country and primitive woods in ten minutes-Nature came up to the very threshold of the city, sometimes even crossed it.

His first natural history novelty in the new environment was a prodigious grasshopper which flew from the ground in front of him to a tree. Immediately giving chase, he was surprised to find the great insect nearly as wild and as fleet as a bird. The grey spotted creature was about three inches long, with a white stripe on its back, and with something the look of a reptile.* But he did not go to Washington to pursue natural history objects; he went there, as we have learned, to be nearer the stirring scenes then taking place in and around the nation's capital.

* Probably the American locust (Schistocerca americana). 
On reaching the city he made his headquarters in the rubber store of Allen, Clapp \& Co., his friend Allen immediately helping him look for work. While waiting for investigations and applications to unroll in true red-tape fashion, he kept occupied, studying the birds and writing about them. Though living on borrowed money, he put on a brave face and strove to reduce his expenses to the lowest figure. His chief expense was for board. He slept in the store on a camp-cot with army blankets. When his pillow-case was soiled, he turned it other side up, and when that was soiled, washed it, and also some of his clothing, at the sink in the store, drying them at the stove. He wore the paper collars and cuffs then in vogue. One night on finding that the laundry to which he had sent his clothing was burning up, he had a pretty anxious time until he learned that his clothes were among those that were saved.

Years later, when, an honoured guest at the White House, he was driven along Pennsylvania Avenue with President Roosevelt, on their way to Yellowstone Park, those days of poverty and early struggle came vividly to mind. It seemed incredible to him that he and that obscure, aspiring youth were one and the same.

During that early period of waiting he wrote his first bird article, which he had started on coming out of the Adirondacks. When too distracting in the store to write, he hunted up some other place. He remembers once or twice writing at a little table in a reception room of Willard's hotel. No wonder the article dragged! When at last it was done and sent to the Atlantic, there was a long wait, during which time he wrote a friend that although he had sent his "Birds" forth, he was expecting they would 
soon come home to roost. But they did not. The Atlantic accepted the essay, "With the Birds," publishing it as the leading article in the spring of 1865 , the first of a long list of bird articles not ended yet. Fifty-five years of writing about the birds, and he is still finding out new things concerning them!

In submitting the article he had unwisely offered to sell it for ten or fifteen dollars, so it was accepted at those terms. Thus early he demonstrated what has always been true of him: if left to himself he will cheat himself in every bargain. A more shrewd and canny author, with one-tenth of his popularity, would have reaped a tidy fortune from his writings, but his unworldliness has stood in the way of that; the lion's share of profits has always gone elsewhere; but the lion's share of affection and appreciation has steadily flowed into the coffers of the unbusinesslike author.

After some weeks of waiting he secured work in the Quartermaster General's Department at Geesboro Point. His first job was to superintend the burial of some negroes who had died in the camps. Then he looked after supplies. for the Cavalry, kept tally on the hayloads, and gave out drugs.

Later they put him in the office, but as there was seldom work enough to keep the office force busy, loafing was common. Preferring to put such slack time to use, he spent it in reading. One day while absorbed in a philosophical article in the Westminster Review, a "high-brow" magazine with a yellow paper cover, one of the assistant quartermasters came in. Bustling about, the other idlers made a great show of working, but the "green hand" from the country kept on reading. "I wasn't going to 
make believe I was busy when I wasn't," he said to his associates when they told him he should have "got busy" when the "boss" came in. In a few days he received his dismissal, the reason, as given later to Allen, being: "About all Burroughs seemed to do was to sit around and read yellow-covered literature!"

It was while he was still at work in the Quartermaster's Department that Grant, Sherman, and Thomas were getting ready to attack Bragg and Johnston around Chattanooga, and just after his dismissal that the threedays' battle took place (November 22-25) with the splendid victory. Hooker's "Battle above the Clouds" and Thomas's brilliant achievements at Missionary Ridge were excitedly discussed in the evening by the young men congregating in Allen's store. The fortunes of the Union were indeed brightening, even if those of our hero were still under a cloud.

Some dreary weeks followed that dismissal, weeks in which he wished himself back at his teacher's desk at Buttermilk Falls with his meagre pay; for he had left debts behind and was daily incurring more. He enumerated those he had left: three dollars for wood, ten for groceries, small bills at the butcher's and the washerwoman's, and one for filing his saw; but he wrote his wife to see his creditors and assure them he would pay every farthing, though the outlook for paying them soon, he had to confess, was not bright. In fact, he was so discouraged he declared his life a failure; that he wasn't as valuable as his old shoes; that he had nothing but ideas, and did not seem able to bring them to bear.

Despondent, he wandered about the city, went to the Capitol, traversed its marble halls and long colonnades, 
listened to senators and representatives, and wondered when the turn in the long road would be reached.

And yet in this dreary time a steady light was shining along his path:

As he was sitting in the back part of Allen's store one evening shortly after arriving in Washington, there had come in at the door a tall figure in grey, wearing a broadbrimmed, grey felt hat.

"There he is! there's Walt!" cried Allen, going forward to meet the Poet, followed by his quiet companion who, though outwardly calm, was in a state of seething emotion.

"Walt, here is the young man from the country I told you about-Burroughs."

And Walt Whitman and John Burroughs, in that first glance into each other's eyes, and first handclasp, became friends.

"I shall never forget Walt's kindly glance, his big soft hand, and his friendly grasp when we first met."

Whitman's comment to Allen after that meeting was, "His [Burroughs's] face is like a field of wheat." The comment that Burroughs made in a letter to Myron Benton was, "I love him [Walt] very much. . . . He is as vast as the earth, and as loving and noble."

Very soon in their acquaintance Whitman began calling his young friend "Jack," and often so addressed him.

It needed Whitman's friendliness, and steady optimism, to tide the younger man over those dark days of officeseeking which followed. His letters written at this time show a disheartened, even bitter, mood. The recommendations he had applied for were unaccountably delayed. Having no wires to pull, he saw others getting 
places while he had none. He was lonely and homesick; his funds were sinking lower and lower.

Early in January, after receiving his letters of recommendation, and the indorsement from his Members of Congress, he hastened to the War Department and presented them. The messenger asked him to have a seat and wait. Three solid hours he sat in that waitingroom without further attention. Then, quitting the room angrily, in desperation he sought the office of Hugh McCulloch, Comptroller of the Currency. Almost immediately he was ushered into the presence of the genial, kindly Comptroller who, on asking him what recommendations he had, received the reply, "I must be my own recommendation." In his Men and Measures of Half a Century Mr. McCulloch tells of this interview; of how attracted he was to the youth with the sturdy form, the honest face, and modest demeanour. As a result, the applicant was told to come around the next day and go to work. So on the 4th of January, 1864, John Burroughs was installed as a first-class clerk in the new Currency Bureau of the Treasury Department.

That night he wrote home that he hardly expected to sleep for a week, so glad was he to have secured his job. And he did not sleep for at least one night: he and his young friends went out and made a night of it - that and one other occasion being the extent of such celebrations throughout his life. He wrote his wife that the piles of greenbacks he had seen that first day were enough to make a miser run mad. Here at last was work and the means to cancel his debts and get on in the world! No wonder he expected to be sleepless for joy!

Hope, promise, and fulfillment followed in quick suc- 
cession at the very dawn of the new year. The period of waiting was at an end; that of work was begun. It is interesting to remember in connection with his employment in the Currency Bureau, though in the humble capacity of a clerk for the Comptroller, that Stephen Burroughs, a brother of his great-grandfather, had in 1790 been conspicuously connected with the financial system of the nation, having, as has been related, invented the system of Federal money adopted under the secretaryship of Alexander Hamilton. Now his descendant was being initiated into the new banking system (the present system of National Banks) which went into use in 1863 under Secretary Chase.

But the glitter of gold, and the fresh hue of crisp green bank notes did not make the country dweller blind to the green and gold of the common things he had always loved. In April (1864) he writes to his friend Benton of finding a magnificent dandelion in front of the Treasury Building: "I first thought some one had dropped a gold eagle there - Secretary Chase perhaps-but on examination found it to be much finer than gold, and probably dropped by a much greater than Secretary Chase." Many years after, in one of his spring poems, we find a poetic line reminiscent of that gold in Nature's Treasury:

When dandelion's coin of gold is freshly minted on the lawn.

At the start the new clerk was sent to the basement with another to keep tab on the workmen who carried the dies and plates for the bank bills back and forth to the engraver's. Each piece had to be checked off and registered when taken away. As there were opportunities for unprincipled persons to abstract the dies and use them in 
the making of counterfeit money, strict watchfulness was necessary. It was the duty of those two clerks to keep a sharp eye on the men to whom those pieces were entrusted. "But I couldn't spy on anything but a chipmunk," said our incorrigible countryman a little apologetically, "and finally went to Mr. McCulloch, asking him if he couldn't set me to some other work. I thought I would die from the dreariness and confinement and inactivity down there, so he moved me upstairs."

Thereafter he had a desk on the second floor of the west side of the Treasury Building. Much time was spent in making briefs of letters, after which he registered and filed them. Some months later he was made keeper of the iron vault where the new, unsigned bank bills were kept. Starting with a salary of twelve hundred a year, he gradually advanced to more and more responsible, better paid clerkships, advancing, oddly enough, to second, third, and fourth-class clerkships, the first-class being the lowest grade. On leaving Washington, ten years later, he was chief of the Organization Division in the Bureau of National Banks, at a salary of eighteen hundred a year, with a bonus bringing it up to twenty-one hundred.

As the new banking system was just organized, work was not brisk at the start. Very little money, compared to later times, was issued, and none of the worn out currency was as yet being returned from the banks. Hence the work required of the new clerk during those first years was not exacting.

Many years later I visited that office with the one-time Treasury clerk, saw the high mahogany desk at which he had written much of Wake Robin and Winter Sunshine, and even saw some of his former associates. One of those 
elderly women told me that although Mr. Burroughs was "always scribbling in his spare time," she had no idea then that he was writing a book. But as no captious quartermaster was there to object to this use of his slack time, he there recalled the memories of former saunterings in woods and fields, weaving them into his early nature essays. Seated at his high desk in front of the iron wall of the vault, he guarded its door. No one was allowed to enter without him. He was responsible for the millions of bank notes it contained.

Office hours were from nine to four with a pause at noon long enough to eat two apples; then dinner at four-thirty, and in the evening calls, lectures, and an occasional play, or loitering in Allen's store. For a time he spent two hours of an evening addressing envelopes for his Member of Congress-a voluntary service in return for his letters of recommendation. Midnight usually found him in bed. Thus passed his days.

In January we find him revelling in the soft, smoky air of the Capital. The streets were dry and dusty, it was often so warm he would lie on the grass of the Smithsonian grounds for an hour or two; there were no signs of frost; the air was still and hazy; a brooding calm like that of October enveloped the city and the Virginian hills.

Looking forward in mid-February to the coming of his wife, he sent on specific directions for the boxing of his books and magazines; for the berries he had dried, and the cherries he had preserved while at the home farm. He forewarned the exacting housewife that when she came she must not peep sharply into holes and corners, as the houses were much neglected, the work being done by darkies; but assured her that the food was clean and well 
cooked. He warned her also that as he had no new clothes, he was looking pretty seedy; he had had his suit cleaned and trousers dyed, which greatly improved their appearance, even if they did "crock off" on his hands. She must look in his face, he suggested, not on his back; and added gaily that his salary of eighty-two dollars and fifty cents for three weeks' work was "almost as much as he could earn raising onions in old Delaware."

At that time Washington was like a country village, the population was only 60,000 . The water of the Potomac was vile. The streets were poor, most of them unpaved; the mud and dirt were frightful.

"I've seen whirlwinds there bring a cloud of dust that blotted out the Capitol," I've often heard him say. It was a great event after the War when they began to pave the streets, beginning with Pennsylvania Avenue.

But whatever Washington lacked, the soft brooding days and the enchanting nights were a delight, and he revelled in the dazzling sunlight which he celebrated in Winter Sunshine, declaring he had never seen anything but second grade sunlight and moonlight until he went to Washington.

In the spring the drying roads, the clear skies, the fresh earthy smell, lured him forth every Sunday for gleesome saunters. He used to hunt snipe where now are solid blocks of buildings and rolling cars; and great apartments now loom in his old wildwood haunts.

On his walks even the crows and buzzards were hailed with delight. The calls of the flickers sounded the same to him as they had in the North. The shrill calls of the spring peepers, the early wild flowers, and the familiar birds-what joy they gave him, cooped up in that office all the week! 


\section{JOHN BURROUGHS-BOY AND MAN}

Sometimes he would hear the mellow flute of the veery around the White House, sounding as wild and sweet as it used to sound in the Deacon woods. On the Smithsonian grounds the whistle of the fox sparrow greeted him in early spring, and in the fine large trees near the Capitol, and on the ground, robins, catbirds, blackbirds, and whitethroats made as free as though there were no signs to keep off the grass. One May morning while walking through the Smithsonian grounds, he was surprised to hear the rollicking music of bobolinks high above him, pushing northward.

He hunted the woods in May to see the thrushes and warblers; to greet old friends and to make new ones. In fact, he says in self-condemnation: "I was pursuing the birds that May and June when our soldiers were dying in the Battle of the Wilderness."

He remembers that spring of ' 64 standing with Whitman on the corner of Newspaper Row, opposite Willard's Hotel, and watching Burnside's army as it flowed through the streets all day on its way to the Battle of the Wilderness. Many of the soldiers who had been nursed by Walt in the hospitals, recognizing him, would wave a greeting, and once in a while one would break from the ranks, rush up and kiss him, and pull him along. Walt would go with them a ways, then rejoin his friend on the sidewalk, only to be hailed anew and pulled along again and again.

How the Treasury clerk revelled in his Sunday walks, sometimes with companions, but oftener alone! Three of them would sometimes start off of a bright, dry Sunday and tramp twelve or fifteen miles, coming in at night feeling like wild colts.

In his essay, "The Exhilaration of the Road," one can 
follow him along the red roads and almost feel the tingling of feet that he felt on starting out on those long "hikes," sometimes along the Tenallytown road to Cabin John Bridge, or up Good Hope Hill, or across the East Branch on the old Marlborough Road that led to Pumpkintown and beyond.

Doubtless the essay just mentioned has had a good deal to do with making "hikes" fashionable. It is a chart and compass for the Independent Order of Walkers, and one who likes to take long tramps finds great joy in reading it. It sets forth one rule for those planning a "hike" which it is well to observe: Always plan ahead for as much as you intend to walk, for, if loaded to carry only one mile, and compelled to walk three, you will feel more tired than if you had walked six, knowing ahead of time that that was to be the length of the "hike." In short, if one knows the stunt to be done, he can distribute his powers accordingly. The real joyous tramp, he tells us, is the one where your heart makes the music to which your feet keep time-then you can walk around the globe without knowing it.

The Dome of the Capitol was not completed when John Burroughs went to Washington to live. For a long time it was a familiar sight to see that enormous swinging arm of the derrick near the top. He saw the huge bronze lady lifted into place. After the Dome was finished it figured in all his walks. It could be seen from all points of the landscape, rising above the hills.

We must confess that those holidays which our Treasury Clerk spent in the woods studying the birds were sometimes spent in shooting them, although the shooting was not for sport, but for identification. We have to remember 
that in those days comparatively little had been written about birds, and there were few collections of mounted specimens accessible for study; and it is really necessary to have a bird at close range, preferably in the hand, to know it thoroughly. To hunt birds with an opera glass had not yet occurred to students; so, in order to learn the birds, the ardent student justified himself in occasionally shooting a specimen, even though it was against the law.

He stuffed and mounted those thus secured; some of that early work is still a credit to his skill. But, bird lover that he is, and always has been, he has never had pleasure in a stuffed and labelled specimen for its own sake. His readers well know that it is the live bird, soaring and singing in its haunts, or brooding the young in its nest, that has ever appealed to him; and it is the bird on the bough that he has made his readers love. Wilson, Audubon, and all the early students of the birds, found it necessary to take life while in the pursuit of their study, but happily that time has passed. We who study the birds to-day can, because of those early ornithologists, name the birds without a gun. In those early years of bird study Mr. Burroughs carried an innocent-looking cane with him which was the case to a gun. The mounted policeman would go tearing along, on hearing a shot in the woods, while he strolled by with that cane. Once one halted, asking, "Where was that shot?" "I heard it over there," replied the culprit, pointing toward where he had been when he had shot at the bird.

Although John Burroughs had met Walt Whitman often in the store of his friend Allen, it was not until he met him one Sunday afternoon along a footpath under 
the trees that they really found each other. Whitman was on his way to one of the army hospitals with haversack slung over shoulder and pockets stuffed full of things for the sick boys. He asked "Jack" to go along with him. Washington was one huge hospital in those days, and Whitman made daily rounds in all those wards, carrying comfort and cheer and countless necessities to the boys. That Sunday was an unforgettable day to the younger man. Unused to sickness and suffering, the sight of those crowded barracks and improvised wards full of wounded men nearly floored him. But the vigour, cheer, and sympathy that Whitman carried and scattered at every step were so invigorating and inspiring that "Jack" soon forgot all else. Whitman moved from cot to cot with a hearty word and a warm handclasp, and usually with some little gift-a sheet of paper and an envelope here, a postage stamp there; an orange, which he would stop and peel and tenderly feed to some fevered lad; tobacco, pipes, newspapers, magazines. Such a medley of things as he drew from that big haversack, always seeming to know just the right thing for each! And how the faces lighted up as they caught sight of him! He was, in fact, a self-constituted Red Cross in the days before that beneficent organization had carried its ministrations to all parts of the earth.

Some days he would go with baskets of oranges or of apples, sometimes he would gather quantities of daisies, clovers, and dandelions, scattering these on the cots while pausing for a word of comfort, or to make note of needs to be supplied at subsequent visits. He would do errands for the boys, write their letters, read to them, urge them to write home, and talk with them about the home folks. 


\section{JOHN BURROUGHS-BOY AND MAN}

He helped them to bear their pain, braced them for their operations; and sat by the dying till the end. He was home, father, mother, sister, and sweetheart to those sick and homesick boys. If he had never written a line, if his deathless poems in Drum Taps, written, as it were, with his heart's blood, had never seen the light, still America's debt to Walt Whitman for his devotion to the boys of the North and the South, during and long after the Civil War, would be beyond expression.

As his young friend saw him pass from cot to cot on his errands of mercy during that first visit and at many a later one, he was impressed with the divinely-human quality of the man -an impression which deepened and strengthened in the more than thirty years' friendship that followed.

"Good-bye, Walt, good-bye!" "Come again, come again, Walt!" the boys would call after him, while many, unable to call, would follow him with eloquent eyes and touching smiles, their looks saying more than any words could say. Some would embrace him. Some of the homesick lads he would bend over and kiss with a woman's tenderness. Whitman wrote his mother that he believed no men ever loved each other as he and some of those poor, wounded, sick and dying men loved each other. $\mathrm{He}$ told her he thought he was able to help them so much because he was so large and well, "like a great wild buffalo with much hair"; that many of the boys were from the Far West and liked a man who had not the bleached and shaved look of the cities.

His letters of scenes in city and hospital during the War brought him in money from time to time. Living frugally, chiefly on bread and coffee, he used all he could scrape to- 
gether to supply the soldiers' needs. After a time, Emerson and other benevolent persons in Massachusetts and around Washington made contributions, so that he had larger sums to expend in his deeds of mercy. On special days, such as Thanksgiving and Christmas, he would go to Mrs. Burroughs and get her to make him pies, cookies, doughnuts, and the like. Then he and Mr. Burroughs would make the rounds of the hospitals distributing the goodies.

During the summer of 1864 while General Early was threatening the nation's capital, our Treasury Clerk made up his mind to take a hand in the fray. Early's army was only seven miles away, and the apprehension in Washington was hourly growing more grave. One evening John Burroughs made his way out Seventh Street, eluding the pickets by skulking about through the fields and woods till he reached the rifle-pits in front of Fort Stephen where the Sixth Corps, which had been hurried up from Petersburg to defend Washington, was stationed. He was halted once or twice as a spy, but finally convinced the sentinels that he was not one-only intent on seeing how it felt to be a soldier:

It shows how lax their methods were. The road was picketed, but all I had to do was to get over the fences and circle about through the fields and flank the pickets. I almost persuaded a sentry to let me into the Fort itself.

He was unarmed, but the soldiers assured him they could quickly supply him with a gun if the enemy appeared. As he lay there in the darkness fraternizing with the soldiers, the Confederates began firing in front of them on a hill about a mile away. When he heard the ping of an occasional bullet overhead, and the thud 
as one would strike the ground, he thought them the ugliest sounds he had ever heard! The war-worn veterans of Grant's Army lay on the ground, some sleeping, others apparently as unconcerned as though on a picnic. How they laughed to see him dodge the bullets! And when the bullets began coming over thicker, and he sought the shelter of the rifle-pits, it was much to the amusement of the seasoned soldiers.

A few hours later a company of soldiers was hurried off into the darkness toward the line of rifle flashes along the horizon. The sickening feeling which came over the would-be recruit, as he watched them march away, proved to him that the stuff of a good soldier was not in him:

If I had been ordered to join them as they went out into the night to face that unknown danger, I fear my legs would have crumpled under me. What a coward I was! Granther Kelly would have disowned me. Darkness always did hold terrors for me from childhood onward, and that night my imagination ran away with me.

But as the night wore on and no attack seemed imminent, he wandered toward the rear, restless and out of conceit with himself. Passing a long, low building which was being used as a hospital, he said to himself, "I can at least be of help here," and going in, offered his services to the busy surgeons. The operating tables were full. The wounded lay in long lines on the floor, or sat crouched by the wall waiting their turns, some groaning, some joking, some in apathetic silence.

He had always had a feeling of faintness at the sight of human blood, but now, much to his surprise, found himself standing at the surgeon's side holding vessels and passing instruments, as composed as the surgeons them- 
selves. But after a half hour or more a deathly faintness overtook him. The surgeon, noticing his pallor, roughly called, "Get out of here!" almost shoving him into the open air.

The air quickly restored him, but the sight of hands and feet piled there in mounds, the odours, and the groans unnerved him, and wretchedly conscious that here, too, he was weighed in the balance and found wanting, he crept in among some bales of hay where, trying to sleep, he waited for the morning. All through the hours he heard the clatter of hoofs and sabres as regiments of cavalry filed by. As soon as it was light he made his way back to the city.

Sheridan's Ride saved Washington from the raid of Early's cavalry, and our Treasury clerk's rejoicing at the removal of that menace had a fervour that was considerably heightened by that one-night bivouac with Grant's men around Fort Stephen.

He often says it was probably the greatest miss of his life - to miss that chance of being a soldier. Nowadays he never sees a soldier boy in khaki without wanting to hug him, just as, after the Civil War, he envied every veteran his experience-an experience he might perhaps have had, had not Granther Kelly, in his soldiering with Washington, so nearly emptied the family powder-horn.

There were times during that summer and fall of 1865 when, seated at his high desk, he and his fellow-clerks would be conscious of a distant muffled sound far down the great corridors, a sound which grew rapidly louder till it became a mighty roar: it was the news of some big Union victory being carried along through the whole 


\section{JOHN BURROUGHS-BOY AND MAN}

Department. Out from their offices he and the other clerks would rush and join the crowd, adding their voices to the rejoicing throng. In August when Farragut sailed into the harbour at Mobile, in September when Sherman's long campaign was crowned with triumph at Atlanta, after which he started on his long march to the sea, in October when the news of Sheridan's mad ride reached there-at such times the sleepy old offices were emptied and the great corridors were a scene of wild rejoicing.

There were anxious times all over the country that summer lest Lincoln should not be renominated and reelected; but the Union victories in the fall were powerful campaign arguments, and Lincoln's reëlection with a popular majority of more than 400,000 showed how the North really felt about him and his policy.

The new Treasury clerk had succumbed to malaria in the fall of '64, and obtaining a furlough, had gone home to recuperate, and to vote. He could hardly drag himself to the railway station, and on the journey to New York, and up the river to Kingston was very wretched; but as soon as he turned toward his native hills, his strength returned as if by magic. After leaving the stage-line he struck out for home, walking easily and growing stronger at every step. Overtaken by a farmer living near Roxbury, he was given a lift. As they rode along, the War, of course, became the topic of conversation; but the farmer's comments about it, and about Lincoln, so enraged his passenger that the latter jumped from the wagon and, shaking his first at the astonished man, declared he would be $d-d$ if he would ride any further with such a d- C Copperhead! The "Copperhead" tried to coax him back into the wagon, but he wouldn't be 
coaxed, and angrily trudged along the eight or ten miles further.

What a home-going that was! He had never known what freedom was before. He kicked up his heels like a cclt in a pasture; roamed the woods with his nephew, Channy; hunted squirrel and ruffed grouse, passing a joyous time in the old haunts of his boyhood; then, after casting his vote for Lincoln, he returned reluctantly to Washington, his high desk, and the big vault.

The spring of ' 65 found the young couple keeping house on Capitol Hill, exactly where the Senate offices now stand. There by their simple, economical living, and the wife's thrift and industry, they managed to save fifty dollars a month out of his salary, to pay up their debts, and to make provisions for a home of their own.

Mr. Burroughs urged his friend Benton to come on and see Lincoln inaugurated:

Walt is here; Spring is here; the bluebird and robin are here. The Spirit says Come; the Flesh says Come; wife says Come; Abe says Come, so Come! . . . I am spoiling for a talk.

But Benton did not come then, and, what is more, Mr. Burroughs himself did not go to the Inauguration:

I went to the woods instead - think of it! when I might have heard that Second Inaugural Address! Mrs. Burroughs heard it. It was a dark day, but just as Lincoln was taking the oath of office she said a burst of sunshine came out, illuminating his face and almost making a halo above his head.

How many times since I have chided myself for going to the woods that day! and about all I can remember of that trip is of finding some wild puppies in a hollow tree. I could go to the very spot now in those woods where that tulip tree stood; a man was there chopping wood; he didn't go to the Inauguration either. I saw the mother of those puppies the other side of Rock Creek, running up and down, crying and yelping, and looking wistfully across, but afraid to venture in the swollen stream. 


\section{JOHN BURROUGHS-BOY AND MAN}

Richmond fell on April 3rd, the day that John Burroughs was twenty-eight years old. Washington was a wild scene of rejoicing. No ordinary demonstration could suffice: for the second and last time in his life John Burroughs went out with the boys and celebrated.

Lee's surrender on April 9th followed close on Richmond's fall. The Confederacy had at last collapsed; the long and cruel war was at an end. The difficult period of reconstruction was at hand, and deeds of mercy were henceforth to take the place of strife and warfare. Lincoln in Richmond, with kind and conciliatory words, and Grant at Appomattox, with generous terms of surrender, sounded the keynote of the spirit of reconciliation that was in time to unite the North and the South.

But how short was the period of the nation's rejoicing! While Lincoln, weary with the burdens borne so long, sought relaxation at the theatre, on the evening of April 14th, on the fourth anniversary of the surrender of Fort Sumter; while the voice of William Lloyd Garrison was ringing out in Charlestown, and liberated slaves were strewing his path with flowers; while General Anderson was raising above Fort Sumter the tattered flag which he had hauled down after Beauregard's bombardment four years before; there, in Ford's Theatre, as our weary President sat in his box, the fanatic, Booth, leader of a band of plotters, who had planned to take the life of Grant, and other patriots also, assassinated the beloved Lincoln!

The gloom that enveloped Washington on the morning of April 15th when Lincoln died was typical of the sorrow that overspread the nation like a pall. Flags were at half mast. Every city and village in the land was draped in black. Men with pale, tense faces, and women with 
tears were sorrowing over the loss of the great soul that was gone. And the Poet whose tender heart and helping hand had so long ministered to the boys in blue, and the boys in grey (for it was he who so significantly said, "Was one side so brave? the other was equally brave") now spoke for the sorrowing nation. The storm-tossed Ship of State was safe in port, but in that glad hour its gallant Captain's cautious hand was stilled, his just and resolute voice forever hushed:

The ship is anchor'd safe and sound, its voyage closed and done,

From fearful trip the victor ship comes in with object won.

Exult, $O$ shores, and ring, $O$ bells!

But I with mournful tread

Walk the deck, my Captain lies

Fallen, cold, and dead.

In their little home on Capitol Hill the morning of the 15th of April, Mr. and Mrs. Burroughs were impatiently waiting breakfast. It was long past the hour when the old Irish woman usually brought their milk, and annoyance at her failure to appear was fast reaching the danger point when, much flustered, she arrived, stilling any reprimands by the bald announcement:

"The Prizident is shot! They do say he is dead!"

Incredulous, they told her she must be crazy; but quickly becoming voluble, she told of the crowds encountered everywhere, blocking her way, as the people surged here and there inquiring for news.

Rushing out for a paper, Mr. Burroughs soon returned with the terrible confirmation. The breakfast went untouched that morning.

Work was suspended in the government buildings for the day. Andrew Johnson took the oath of office amid 


\section{JOHN BURROUGHS-BOY AND MAN}

the tolling of bells and the fast-gathering gloom that overspread the land.

That afternoon as Mr. Burroughs started to drive out beyond Fourteenth Street to a nurseryman's after strawberry plants, he was held up at the boundary line by a sentry. No one was allowed to pass. Martial law was established. Every exit from the city was guarded. Already a vigilance was on foot that in time apprehended the band among which the foul crime was hatched.

To return to the home on Capitol Hill and follow the fortunes of its inmates: There on an acre of ground they lived in a quaint brick house almost within shadow of the Dome of the Capitol; and there, after office hours, the Treasury clerk worked on his miniature farm, pottering about contentedly among his potatoes and pumpkins and chickens, going reluctantly to his daily work, and returning eagerly to his garden in the late afternoon.

He says he could look up from his hoeing and cast a potato almost in the midst of that cataract of marble steps on the north wing of the Capitol. This was the antidote he had to have, farmer that he was, for the noxious influence of life indoors. Once in his garden, he could hoe under the blue devils in short order, and while getting rid of dock and red-root, could also rid himself of many a troublesome growth in his mental acres. But he was not content until he had a cow. So sending to his native state for one, when the time for her arrival came, he went excitedly to the dock at Georgetown to meet the boat.

The clerk, reading from the bill of lading, said, "One cask for you, sir," to which he answered, "I hope it's a cask of milk, I'm expecting a cow." 
"It says here, 'One cask." "

"Well, let's see it-I'll wager it has horns, and is tied with a rope." And on investigation there she stood on the forward deck contentedly chewing her cud-Chloe, a curly-pated, golden-skinned Devonshire, from the northern hills.

It was a frisky cow that her master led from the dock to his home on Capitol Hill. As he piloted her along Pennsylvania Avenue she kicked up her heels under the very walls of the Capitol, and cut capers in front of the White House. It was in the days when cows had the freedom of the city; when goats cropped the rose-bushes through the pickets; and pigs dreamed dreams under his garden fence. In fact, the cows of his neighbours were given altogether too much freedom in that Arcadian city. One old muley cow was deeply concerned as to how she could get into his garden, of which she had had alluring glimpses over his high fence. One day he had caught her peeping at his cabbages through a knot-hole, and shortly after saw her lift the gate-latch with her nose and calmly enter the sacred precinct, though she scampered off precipitately enough when he appeared.

After Chloe was duly welcomed by the housewife, and admired by Old Drewer, the coloured factotum, she was put in the stable for the night; but so enamoured of her was her master that twice during the evening he had to light his lantern and visit his treasure before going to bed. And in the morning- "Ah! in the morning," he feelingly observes, "the coffee had experienced a change of heart."

Chloe was soon initiated into the mysteries of city life. Her master conducted her a few times to the nearest common, then left her to shift for herself. When he would 


\section{JOHN BURROUGHS-BOY AND MAN}

let her out of a morning, she would pause and consider whether to wend her way toward Kendall Green, or over by the Big Spring, or out around Lincoln Hospital; and after stretching out her neck and blowing a blast on her trumpet would placidly go forth. Pretty punctually, between four and five in the afternoon, he would see her white horns above the gate, and hear her impatient lowthe countersign which gained her admittance.

After two summers, Chloe's returns not measuring up to the required amount, her master reluctantly decided to part with her. One can hardly forgive him, nor did he forgive himself, for exposing the gentle creature in the market-place. There he and Chloe stood submitting to the scrutiny of the white-aproned butchers who flocked around. An old Irish woman came along and stationed herself and her charges-a sow and five pigs-next, to them; and the man with the cow, and the woman with the pigs, compared notes, condoling with each other over the impending fate of their "darlints." A friendly reciprocity showed itself: when she went away for a few minutes, he minded her pigs, and when he strolled about, she minded his cow.

Poor Chloe! how she shrank from the hands of those market-men! How entreatingly she lowed whenever her master left her side! And when the money for her was counted out, and he surrendered the rope to her purchaser, her master, turning for a parting glance, caught a look of alarm and incredulity that would have melted a far harder heart than his. But it had to be. Other cows came and went after that, but none ever filled the place that Chloe held.

Whitman often took breakfasts of a Sunday in the 
Burroughs household. He was very fond of the good coffee and pancakes that Mrs. Burroughs made, but was rarely on time, which was a sore trial to the most punctual of women. They always allowed him a margin of an hour, but it was often long after nine before he appeared. On the mornings when he had not come by nine, some of those cakes went on the griddle, Walt or no Walt. Finally they would spy Whitman coming slowly along with his hands in his pockets, with that rolling sailor's gait, and as if he had the leisure of all eternity. By that time Mrs. Burroughs's cakes were cold and she was hot, but Walt's morning smile warmed up the cakes, and cooled the temper, and soon she had a plate of steaming fresh cakes in front of him, and he and "Jack" were discussing' them with praiseworthy dispatch.

And then they would go somewhere for a stroll, or sit on the steps of the Capitol and have long, long talks.

When they had rented the place on Capitol Hill, they inherited as a part of its equipment, Old Drewer, the darky man-of-all-work, an old white horse, and a ramshackle wagon. With Old Drewer, as with most of the coloured folk of those days, "What's Massa's is mine." One day Drewer just naturally took some apricots from his mistress and sold them. Having proof of his guilt, she accused him. Denying the charge at first, as the inexorable accusations were pushed, Drewer dropped his woolly head and owned up.

One day, on begging for an afternoon off, his mistress; having some whitewashing for him to do, objected. At his crestfallen look she inquired why he wanted to go.

"Laws, Missus, they's going to be a hanging!"

"A hanging! But why do you want to see that?" 
"Why, you see, Missus, he's a membah of ouah church, an' ah wants to see him hung."

On his little city farm Mr. Burroughs kept chickens and took great joy in their care. There were fifteen of them and a specially fine lot they were. He knew them individually and was greatly attached to them; used to talk to them; and held and nursed them when they were sick. Faithfully had they laid eggs for him, and followed him about; they were almost like members of the family. Among them was a turkey which he was fattening for Thanksgiving.

One morning on going very early to the little barn he noticed that the door-strap as it hung down in the uncertain light was slit through. On opening the door, behold! every chicken was gone, and the turkey also! It was a bitter moment. Not only were many a breakfast and dinner gone, but his pets were gone!

When their coloured handmaiden came that morning and learned of the theft, she "reckoned" she could tell him where to find his chickens: she had heard a great cackling and an unusual commotion the night before in a place not far from where she lived, and declared that "them no 'count niggahs thar had sholy toted off Massa's chickens."

Convinced that Mandy had heard the distressed cries of his beloved fowl, and following her explicit directions (as explicit as a darky can give), the chicken owner started out in quest of his pets.

Sure enough! there in the basement of a little house which Mandy had indicated, he found two mulattos with fifteen chickens and a gobbler, the fowl having been killed and picked, but their heads left on: 
No one could fool me about those chickens. I knew them by their heads. I could have wept as I saw them spread out there. When I went in, the darkies had looked surprised and uneasy, but as I coolly asked if those chickens were for sale, their concern was somewhat allayed. One said he wasn't sure, he would have to wait till the "boss" came in; or, should he go and fetch the "boss"? Yes, I told him to go, but to be quick about it. He was gone so long that the other darky said he better go and hurry him up, and off he went, too; and neither of them came back! But I was in possession of my chickens! Hailing a police officer, I told him the story, and having convinced him that those were my property, he told me to take them. The room was empty save for the fowl and a horse blanket. The officer asked if that blanket was mine, too. I told him it was not. Reasoning that that was stolen also, he said he would take the blanket, and I might take the chickens.

Well, we had chickens to eat till we were heartily sick of them; we gave chickens to our friends, and sold some-fifteen chickens and a turkey go a good ways in a small family. 

MATURITY 



\section{CHAPTER XIII}

\section{STILL WORKING FOR UNCLE SAM}

(1867-1873)

To be keeper of a vault where fifty or sixty million dollars' worth of bank notes were stored was a pretty responsible position. John Burroughs as guardian of this vault kept not only a strict account of all the bank notes that went in and out of the vault, but also had certain men come every month and "prove the vault," to make sure that its contents tallied with what the books showed it to contain.

The new unsigned bank notes were done up in small packages containing many thousand in a package. These were arranged on shelves in a closet in the vault, in alphabetical order, and sent out from time to time to the various National Banks throughout the United States.

One day a fifty dollar note came in from a bank in New England, with a statement that this note, which bore the name of their bank, had never been issued to them. It had clearly been abstracted from the vault and put in circulation without having been signed by the president and cashier of the bank for which it had been prepared. The signatures upon it were forged.

This was a serious matter. The vault-keeper, on examining his books, found that there should be a package in the vault of twenty thousand dollars belonging to that particular bank. He opened the closet in which the package should be, and alas! it was not there! 


\section{6 JOHN BURROUGHS-BOY AND MAN}

Imagine his consternation! He alone was allowed to go in the vault unaccompanied. All others who went, went only with him, so he alone was responsible. It was a grave and terrible revelation to him. He searched the vault to see if by chance the package had got misplaced. His state was a pitiable one. "One of us in this room is guilty," he said to his fellow-clerks. "If I am, I want to know it," he added, almost beside himself with this shadow of suspicion resting so heavily upon him.

Refusing to go home that night, he stayed and searched over and over every nook and corner of the vault. Several other clerks, as well as the Comptroller, stayed with him to help in the quest, and assured him of their confidence in his integrity.

The matter was promptly reported and investigations set going, but they found no clue for a long time. The bank concerned cancelled that plate so that no more notes of that denomination could be issued, and called all others in as fast as it could. Circulars were sent to every National bank requesting all notes of that denomination to be returned to the Comptroller for cancellation and destruction.

In time, a second forged note came back from the same bank. Looking at it sharply, Mr. Burroughs said to himself, "That is S- ' ' handwriting." It was a sprawling, indefinite signature, a clumsy attempt at imitation of the usual signatures from that bank.

Now S - was a trusted, wide-awake coloured messenger, long employed in the offices, who frequently carried packages into the vault, though always in company with its keeper.

When Mr. Burroughs confided his suspicion to some of 
his fellow-clerks, they were disinclined to suspect $\mathrm{S}-$; but having so much at stake, the guardian of the vault was bound to follow up his surmises.

Pondering long and earnestly on all the exits and entrances of others to the vault, he finally concluded that the theft had taken place during a recent cleaning of the big office when the coloured messenger and clerks had carried the ledgers, ink wells, and other office paraphernalia into the vault to get them out of the way. He had, of course, stood in the vault while the men were going and coming.

Now, with his suspicions aroused, he scrutinized the situation to discover how it was possible for one to abstract a package with him standing there on guard. The inner door of the vault swung back against the closet where the bank notes were kept; he saw that, as a messenger would turn to go out, he would for a brief instant be partly hidden by that door; and, if very deft, might easily have seized one of those small packages and concealed it in his clothing, or, perhaps in the piles of ledgers being carried back to the office.

Convinced of S-'s guilt, he undertook a little private detective work. Deciding to find out more about the habits and mode of life of the suspected man, he called on him one evening, ostensibly to enlist his services in getting on the track of the thief. He found that S- had recently moved and was living in a quarter of the city and in a style far beyond what his wages would warrant. $\mathrm{He}$ found other evidences of lavish expenditures on his part, all of recent occurrence. His convictions were strengthened.

Detectives being put on the man's track, enough circumstantial evidence was obtained to bring him to trial, 


\section{JOHN BURROUGHS-BOY AND MAN}

but the trial was almost a farce. Although his guilt was pretty satisfactorily proven, he escaped conviction, for at that time the championship of the coloured people was so strong in Washington that Republicans were not willing to find a negro guilty when they knew he was. So although $\mathrm{S}$ - lost his position, he escaped the full penalty of the law.

In the fall of '65, E. M. Allen, the friend so influential in bringing Mr. Burroughs to Washington, married the poet, Elizabeth Akers.* They were married in the Burroughs home, and moved to Richmond, Virginia, where the versatile Allen's energies were henceforth expended in the running of a foundry. With the wear and tear of body and soul on that sensitive nature, the distance, the struggle for existence, and family cares to engross him, Allen's letters came infrequently, and the former friends gradually drifted apart.

Other friendships were formed, chiefly with Walt Whitman and William D. O'Connor, with Parnell of the Internal Revenue, and with Dr. Frank Baker and Aaron Johns-veterans of the Civil War. Unforgettable were the Sunday night suppers of Whitman, Burroughs and O'Connor, and unforgettable were the tramps of Burroughs, Baker, Johns and Parnell.

William O'Connor rented a room in their attic for a time and there wrote madly day and night on his story, The Carpenter, stimulated by tobacco and coffee. His host used to throw up ripe plums against his window-pane to regale and divert him.

The book on Walt Whitman $†$ on which John Burroughs

* Perhaps best known for her poem, "Rock me to sleep, Mother."

† Notes on Walt Whitman, Poet and Person. 
worked for two years was published in 1867. This was his first book. It preceded his first nature book, Wake Robin, by three years.

In the fall of 1867 the Burroughs couple moved into their own home out in the suburbs, on V Street. This "house that Jack built" was a substantial brick house of ten rooms and a basement. There they cozily settled down to enjoy their new quarters. The owner, writing to Myron Benton of their new and tidy home, said, "Ursula does her own work, and even the cat wipes her feet on the mat before she ventures inside." "We have a nice front yard," he continues, "and a large garden. The whole thing cost me five thousand dollars, or will when it is paid for, which will be a year and a half yet. The upper part rents for twenty-one dollars a month."

After the years of struggle and hardship through which we have followed our author, it is good to see him at last comfortably established in a home of his own, with a steady income, and enough leisure to poke about the fields and woods and play Paul Pry with Nature.

That V Street house was built near the site of an old Catholic cemetery. When digging his cellar Mr. Burroughs had uncovered two little coffins. He put them back again, so used to tell his friends, facetiously, that he "had buried two children."

His work in the Currency Bureau continued for nine years, also the Sunday walks and the magazine writing, with the all too short vacations in the Catskills during the "purgatory of mid-summer at the Capital." He used to say the heat was so great there as to melt his steel pens. "Birch Browsings," "Speckled Trout," and many another article resulted from his brief sojourns in his native haunts. 
Other articles on literary topics were frequently appearing in the magazines during these years, articles on Emerson, on Victor Hugo, on "Nature and the Poets," and so on.

And thus the years passed.

After Grant and Colfax were elected, Mr. Burroughs wrote Myron Benton to come on and help him inaugurate Grant. Grant once came into the Treasury vault during his presidency, and was shown around by Mr. Burroughs who, though somewhat abashed at being at close quarters with the silent man, explained things as best he could, Grant walking about the vault with hands behind him, asking a few questions, but saying little else.

One Saturday night Mr. Burroughs and his chum, Frank Baker, camped out on High Island above Georgetown, on Sunday walking up the Potomac to Dam One where they went in swimming. They thought to swim to the other shore but were utterly deceived by the distance. It was not far from the brink of a low dam and, before they realized it, they were being pulled rapidly to its edge. Seeing their danger, Burroughs called to Baker warningly, but it was too late. Baker went straight over, head first, and was carried down by the current into a pool below. Burroughs was pulled into the current sidewise and over the brink, but was mercifully caught in an eddy and carried in behind a rock where, badly strangled, he managed to cling until he could recover himself. In the midst of his own peril he had seen Baker's white body being tossed in the foaming waters. The feeling of utter helplessness which he had while strangling there, weak as a baby, and scarcely. able to cling to the rock, he will never forget. At length, managing to climb to the top of 
the rock, he perched like a cormorant there, watching Baker emerge from the roaring water and swim for the shore. By means of the sign language he asked Baker if he should swim down. Baker signalled emphatically No; he had been badly scraped and bruised against the rocks. Hustling into his clothes he rushed away for means of rescue. There on the rock in the pitiless sun sat his companion until his return with a man and boat, and a long strong rope. Anchoring the boat above the dam, they threw down one end of the rope to Burroughs to pull him up, but, the anchorage not proving heavy enough, he almost pulled them and the boat over the dam. By means of heavier stones they finally succeeded in anchoring the boat securely enough to pull him over the dam and into the boat, not, however, until his back was severely blistered from the long seance on his rocky perch.

His home-coming after the escapade was marked by results customarily meted out to truants the world over: when rehearsing his perilous adventure to his wife, her chastisement, though not corporeal, had almost that effect on the sun-burned victim with his spent strength and his lacerated feelings. Upbraidings for his irreligious act of camping in the woods and swimming on the Sabbath day alternated with copious tears, as his narrow escape was borne in upon her, from time to time, in the midst of the soundly administered chastisement.

The year of 1871 was marked by two important events in the life of our author-the publication of Wake Robin, and his first journey to Europe.

The United States Government sent him and two other clerks to England to convey fifty million bonds which were to take the place of other bonds being refunded. 
It was a tempestuous voyage and the old ship-the Scotia, a side-wheeler of the Cunard Line-kicked up her heels a good deal. He was pretty sick and grew thin. He couldn't "go" the food, and wrote home that he longed for lots of things which his wife knew so well how to fix:

I wanted some of your pickled peaches; I wanted "a strawberry short-cake; I wanted a speckled trout. . . . Oh, the bitterness I have spit into the bitter sea!

On landing in Liverpool they drove out into the country, where he jumped from the carriage and eagerly plucked dandelions, white clover, daisies, and yarrow-overjoyed to be among growing things once more. He marvelled at the fields, green and smooth as lawns, and separated by hedges, and as they rushed through the heart of England, at sixty or seventy miles an hour, it all seemed like one vast garden to him.

It took the Treasury clerks many days to destroy the old bonds. Ten thousand were destroyed at a single blow from a heavy wooden mallet which punched out a hole in each of them. Later they were burned. After these were disposed of, he and his associates were free to go wherever they chose until the time for sailing. At first they kept together, but the gait of the other two was too rapid for him. As they disposed of St. Paul's Cathedral in fifteen minutes, and of the Tower of London in about twenty, he decided to go by himself and get acquainted with the Old World in his own way.

He was greatly excited by the roar of the great city, and the strangeness of it all. Buying a map of London, he would start out in whatever direction he felt drawn, keeping on as long as interested, then when wanting to find himself, would look up where he was on the map, a course 
which led him to "do" London in a most unconventional way.

He almost collapsed in St. Paul's from the powerful emotions experienced there. The Miltonic effect of the architecture, with that London atmosphere like a veil enhancing its beauty and mystery, stirred him to the depths.

As he wandered in museums, parks, cathedrals, and picture galleries, he grew more and more astonished at the magnitude and vastness of London:

I look and look till my head swims, and have to come away from every place without seeing near. all. Before I get half through any of the museums, I begin to hope and pray, "Now this is surely the last-I can see no more," when there open, right and left, vast halls and galleries crammed full of the most interesting objects, and I shut my eyes and rush out of the building with a feeling of great relief. I am beginning to long for the country and a little peace and quiet, and to-morrow shall go out to Oxford and Stratford-on-Avon, and toward the end of the week leave for Paris, again to be stunned with sights and sounds.

Before leaving London, however, he had some memorable experiences. He dined with the Rossettis, heard Spurgeon and James Martineau preach, and Moncure Conway lecture.

In talking with Conway he had mentioned that he had walked in Cheyne Row and gone past the house where Carlyle lived.

"Gone past it! We'll go in. I'll take you there," said Conway.

"Oh, no. I don't want to beard the lion in his den," he hastened to protest.

"He won't paw or claw you if you go with me; besides, it's only geese that get plucked there," declared Conway. So they went. 
Carlyle was walking alone in the gloaming when they reached there. In a genial mood, he delighted them for two hours with his rich and eloquent talk.

When Conway told Carlyle that the American visitor had intended to content himself with going past his house, until he took him under his wing and brought him in, it reminded Carlyle of his own experience in going to Scott's door: He had had with him a message from Goethe, but even with that, felt reluctant; and when, on ringing the bell, he learned that Scott was not at home he went down the steps greatly relieved, and could not persuade himself to try it a second time.

They talked of English birds and American birds. When Mr. Burroughs told Carlyle that the English sparrow had recently been introduced into America, Carlyle exclaimed ironically, "Introduced! introduced!" and laughed a strange sarcastic laugh.

Letters home tell of his experiences in the music halls; of seeing a play (The Woman in White); of what he eats and what it costs. By their means we can follow him pretty closely in his sight-seeing on foreign soil. One day he records his dinner: roast pig, potatoes, turnips and celery, with one pint of bitter ale, an apple tart, and jam pudding -all for two shillings and four pence!

One evening as our unsophisticated traveller was coming out of a London music hall he was jostled by a big, goodnatured German who apologized profusely, and with whom he was soon engaged in the friendliest conversation, comparing notes and experiences as travellers will. Expressing admiration for Americans in general and our traveller in particular, the German declared his intention of abandoning his unsatisfactory quarters the next day 


\section{STILL WORKING FOR UNCLE SAM 265}

and taking lodgings under the roof with his new acquaintance. On parting, they agreed to walk together on the morrow.

Accordingly, on the morrow they set out for King's Cross, the German beguiling the time with a lively account of a recent steeplechase. On arriving at a little ale-house, he proposed they stop for refreshment. The dingy little coffee-room to which the barmaid led them was most uninviting -an unused room with dusty tables and benches and high windows permitting no view of the street. Our friend felt constrained, but the convivial German, seating himself with a lordly air, ordered the ale, and they were soon comfortably quaffing their bumpers, the constraint rapidly diminishing with the ale.

During a short absence of the German from the room, a country fellow, much ruffled, entered, rushed around, violently rang the bell, then seated himself near the American and vociferously held forth:

The worst part of the town I've been in yet-cahn't even get Scotch whiskey 'ere.

I went into a 'ouse just below 'ere and seeing a man with a hapron on, says I, "Waiter, bring me some Scotch whiskey and 'ot water," and 'e swelled hup and said, "I'll 'ave you to know I'm not the waiter; I'm the landlord."

" 'Ow was I to know?" said I; "all the same, I want some whiskey."

"But you cahn't 'ave no whiskey'ere. I'll not be called a waiter in me own 'ouse." So I told 'im to go to the Devil, and left the place.

I wonder if they know 'ow to treat strangers any better 'ere.

And, his order being given, he was soon happy with his hot Scotch.

He was a fresh-faced ingenuous-looking chap in grey cheviot and stove-pipe hat. A three-days' beard was on his face. It was evidently his first trip to London. 
The German reappeared, and, diverted by the garrulous Englishman, the three sat long in friendly converse.

With the utmost naivete the countryman explained what had brought him up to town-a lawsuit, resulting so favourably that he was intent on a little jollification. His lawyer had made him give up most of his money, but he had kept back a few banknotes unbeknown to him. He regaled them with his experiences of the previous night in a dance-hall where the girls had got the better of him, drinking wine at his expense, and inveigling him into other expenditures, telling it all with great candour and enjoying the mirth his recital evoked, his only concern being lest the report of the affair get back to his sister Mary. His new acquaintances grew apprehensive for the unsophisticated chap, and the German warned him against going about London with so much money in his pocket. "'Ow can I lose it with me coat buttoned so?" said the verdant one as he put the loose package back in his pocket.

But the German, assuring him it was unsafe, said he would better have left it with his lawyer; that he never carried but a few pounds about him, no prudent traveller did; and he appealed to the American to confirm his statement. The American declared he seldom left his hotel with as much as a five-pound note in his pocket. -

"But I 'ave enough more if I lose this," argued the Englishman, as he said that he and Mary had just come into a property of seventeen thousand pounds. According to the strange terms of his uncle's will, five hundred pounds were to be divided among the poor, not English poor alone, but the needy of any nation; and his chief concern was to get that five hundred pounds off his hands.

"I shall spend one 'undred pounds among the poor of 
me own town, and 'ope to meet trustworthy gentlemen now and then who will 'elp me to distribute the rest. I gave fifty pounds yesterday to a man at me inn, to spend among his poor in Glasgow."

"You gave it to a stranger?" incredulously asked the American.

"Oh, yes, but 'e showed me as 'ow 'e 'ad money of his own-'e didn't need mine-that's all I wanted to know."

The German and the American exchanged glances, and the German volunteered:

"You will have little trouble in finding people to take your money on such terms. I myself would gladly be charitable at your expense - the late war has made many poor in Germany."

"Good!" said the confiding greenhorn, "show me that you've a 'undred pounds of your own, and I will give you another 'undred to spend among your poor, and take your receipt for it. You can put a notice in the Times with the names and dates-all I want is to show that me uncle's will is complied with."

Seeing that this fool and his money would soon be parted, his hearers decided to undertake the distribution of some of it. Yet it was with a feeling of shame that the American seconded the Teuton, saying to the simpleton, "And I, too, will bear your alms to some worthy poor in my country, and see that it is judiciously expended."

"What poor 'ave you?" the Englishman shrewdly asked.

"Plenty of them-the freedmen are much in need of help."

Satisfied, he said, "Very well, just show me that you 
'ave money of your own and don't need mine, and you shall 'ave a 'undred pounds for the freedmen."

"I have very little with me-you will have to come round to my hotel."

"I have some," said the German, "I hardly know how much," and he counted out some Bank of England notes.

"Show him what you have," the German said significantly to the American- "don't let him think you are penniless."

"Oh, I have only a little change-not more than two guineas in all," and with embarrassment Mr. Burroughs produced his open palm.

"Put up your money, gentlemen; I've no doubt you are both responsible gentlemen. I can trust you to act as me agents in this matter.".

"Come to my hotel," said the German, "or to my. banker's-I can show you five times that amount.".

"Yes," joined in the American, "meet us this evening at my hotel, the Inns of Court, and we will show you that we are all right."

"No, I start 'ome to-night-Mary is expecting me."

"Then let us arrange it now," suggested the German. "Where do you need to go," he inquired of Mr. Burroughs, "to get your money?"

"To my hotel and to my banker's, both."

"Where is your banker?"

"On Lombard Street."

"That suits me. I know a banker there and can get all I want," said the German.

The Englishman wanted to pledge his agents in another bumper of ale, but as that he had already drunk had given the American a queer feeling, he abstained. 
" 'Ere's a sovereign to pay for the cab-this is to accommodate me," said the simpleton, agreeing to await them there.

Taking the gold, the German called a cab and they left him, marvelling that anyone could be so green, and could have been in London twenty-four hours without being robbed. Deciding to keep an eye on him till he was started for home, they wondered if they ought not to warn Mary to accompany him the next time he ventured up to town.

When Mr. Burroughs explained the project to his banker, an American friend of long-standing, that friend, moved by his enthusiasm, offered to lend him the money if he did not have enough by him; but his friend's partner, a Londoner, raised his eyebrows, saying nothing, a silence evidently having its effect upon the American member of the firm.

"You don't suppose this is an attempt to rob you?" he tentatively asked as Mr. Burroughs was leaving with the fifty pounds.

"Oh, no!" he confidently rejoined, "that is out of the question."

On regaining the cab, as the German was not there, he supposed him to be still at his banker's, but presently, on seeing him emerge from behind a nearby cab, suddenly grew suspicious of him. What if it were all a put-up game, and he were in collusion with that greenhorn?-an ugly thought, which he pushed aside; but as they drove to the lodgings, he found his enthusiasm for the scheme rapidly oozing away, while the suspicion that he was being victimized kept returning. The effect of the ale was wearing away, and the scales now dropped from his eyes. It was 
raining, which added to the uncomfortable feeling now possessing him. Glancing at the German, he detected a furtive look unnoted before. He recalled all the little touches of the apparently verdant Englishman and at last decided that, instead of being a greenhorn, he was a consummate actor. Humiliating as was this conclusion, it forced itself upon him. Then he set his wits to work to circumvent his companions, and give his own part as artistic a finish as they had given theirs.

The German, though loquacious, was observant, evidently detecting a change in his companion's mood. On arriving at the inn, he invited himself up to the room to see his quarters. A cold wave passed over the now apprehensive American as they entered the room. While moving about, under one pretext and another, he caught the German observing him narrowly through the mirror. Going to his trunk and busying himself there, he ostensibly took out more bank notes, soon announcing himself ready to return. With alacrity, preceding him, the German hurried out to hail the cab. He, lingering in the hallway, told the burly porter to follow them immediately in a cab, alight whenever he did, and enter the coffee-room a few minutes later.

As they drove along his thoughts were busy devising a way to end the matter. To cause their arrest would be to detain himself as a witness. He must hit upon some other scheme.

Turning to the German he said, "Do you know, the more I think of this, the more I believe it is a scheme to rob us."

"It can't be," said the German, alarmed.

"Yes, it is; that fellow has accomplices. He means to get our money. Do you go armed?" he queried. 
"No, do you?" anxiously asked the German.

"Always; an American carries a pistol as much as he carries a jack-knife; and he isn't afraid to use it, either."

"So I have heard," said the German, looking wistfully out of the cab window; then tremulously, "But you wouldn't shoot a man, would you?"

"Let him try to rob me, and see whether I will or not," and the doughty American assumed his sternest manner.

Just then the cab stopped at the lonely ale-house. As they got out, another cab stopped half a square behind. His companion, excusing himself a moment, lingered without. Burroughs passed inside where the verdant one was waiting, apparently mellower than ever from the "'ot Scotch," though he asked rather anxiously where the German was. Just then the burly porter forced his way into the room in spite of the barmaid's attempts to stop him, and the Englishman, getting up precipitately, and saying that he better go and hurry up their friend, left.

As Mr. Burroughs sat there informing the porter of the affair, a forbidding-looking stranger opened the door, glanced expectantly about, and hastily withdrew. He was doubtless an accomplice who saw that something had balked the game. The others did not reappear, and $\mathrm{Mr}$. Burroughs and the porter lost little time in shaking the dust of the ale-house off their feet.

After this our traveller speedily left the smoke and uproar of London behind, and sought the South Down hills. There he listened to the skylarks, two or three hundred feet above him, as they poured down their ecstasy of song; he visited Oxford, and Shakespeare's home, had a glimpse of France, of Dublin, Cork and Queenstown, and sailed for home via the White Star Line late in November. 
It was hard to settle down to work in the Treasury Department after that October abroad, and the restive clerk began to think more strongly than ever of a project of raising trout which he had been considering for some time before going to Europe-a wonderful cold spring near Washington appealing to him, he and a friend thought they could profitably carry on fish culture there, if they could get control of the spring. But even after abandoning the project his unrest continued, and in 1872 he wrote Benton inquiring the price of land in his locality. He wanted to quit working for Uncle Sam and go to farming. His summer vacation amid the Catskills, and a recurrence of malarial symptoms on his return to Washington, increased this inclination. Accordingly, resigning his position in the Treasury Department the last day of the year, he quit Washington almost as suddenly as he had quit schoolteaching to go there, ten years before. He was not yet, however, entirely freed from the coat tails of Uncle Sam, for he was appointed as Receiver of a broken bank in Middletown, New York, and went there on January 1, 1873 , to begin the work of disentangling the snarl in that bank's affairs. The snow was deep on reaching that little northern city, and it was a rugged winter he spent there, but it proved a tonic to body and mind after the long sojourn in the enervating climate of Washington. 


\section{CHAPTER XIV}

\section{THE FRUIT FARMER}

(1874-1900)

IT was natural that the boy who was always ready to go berrying and apple-gathering, who was even ready to gather Deacon Scudder's apples and "Aunt" Dolly's pears when those proved more alluring than fruit in the home orchards, should when a man, and tired of working for Uncle Sam, turn to fruit-farming as a means of livelihood.

While he was Treasury clerk he had to deal with such sordid things as figures and bank notes, but when he worked for himself, he would work with things worth while-apples and pears, berries, currants, grapes.

While still in the Currency Bureau in Washington, John Burroughs had written Benton that he felt like a fowl with no gravel in its gizzard; that he was hungry for the earth, could eat it like a horse, if he could only get at it. But the work as receiver of that broken bank in Middletown held him pretty closely for a while, postponing for many months his longing to get back to the soil.

After leaving Washington he had also been appointed National Bank Examiner for certain banks in the Hudson River counties, which work occupied him for four or five months of each year up till 1885 when President Cleveland's election happily ousted him from government employ. At last he was free to indulge his craving to engage in fruit-farming on a considerable scale. 


\section{JOHN BURROUGHS-BOY AND MAN}

As the work with the banks did not occupy all of his time, he began, a few months after going to Middletown, to cast about for a place in the country. Looking first on Long Island, then in various places along the Hudson, he finally bought a nine-acre farm near Esopus, about eighty miles north of New York City, on the west shore of the river. At that time the nearest post office was two miles away, but later one was located near him, at West Park, N. Y. This place has since been his home.

Most of the country-seats round about had houses of brick or of pine, but he wanted a house of stone with timber finish to the gables of unstained wood. So when he found a stone-heap near the farm which he was considering, that strongly influenced his decision.

The land slopes east by south down to the river's brim -an ideal exposure for fruit-growing. And here he began to raise, on a small scale, berries, peaches, pears, and Concord grapes. Because of its location so near the river, he named his place Riverby, later giving the title to one of his books.

In the summer of 1873 he began building his house, and in late November of the next year moved into it. What a good time he had getting out the stones! $\mathrm{He}$ would spy them beneath the moss and leaves; their warm grey tones delighted his eye. The master mason used to declare "the boss" to be worth six men in hunting stone. He often says that he built into his house every one of those superb autumn days which he spent in the woods thus occupied. The lintels to the windows and the doorsills, formed of the "wild" or undressed stone, came from the nearby ledges.

He had to scheme to prevent the masons from making 
the stone work too smooth and finished; he would let them get the walls ready to point up, but would not let them do the pointing; and he made them close the joints with just as little mortar showing as possible, sprinkling that with grey sand to tone it down.

The wood used in the house was personally selected. Climbing the mountains in search of the choicest trees, he helped saw them down and haul them to the planing-mill. Some came from nearby woods, and some from the home woods in the Catskills-chiefly butternut, cherry, curly maple, ash, and oak.

While his house was building, noticing one day in Poughkeepsie a picturesque stone house that pleased him, after scanning it on the outside from various points, he rang the door-bell and asked if he might be shown about. It did not occur to him to tell who he was, or just why he made the request. He had on his old clothes, and a recent cut on his thumb was wrapped in a soiled rag. The butler, on listening to his request, said he would speak to the madam. Madam came, and after one hasty look, closed the door in his face.

"I shall never forget my mortification. She must have thought I was a burglar. Evidently thinking better of it, a moment later, she called out that I might look around outside if I wished; but giving only a hasty glance, I retreated, covered with confusion."

One day when his chimney was nearing completion, the Scottish mason failed to appear, having decided to take a day off for something more than a "wee drap." Impatient at the delay, Mr. Burroughs climbed upon the roof and began himself to complete the chimney. The tipsy Scot, who lived over at Hyde Park, on looking across the river 


\section{JOHN BURROUGHS-BOY AND MAN}

and seeing a man engaged on the chimney, thought some other mason had got his job, a thought which sobered him so much that he hired a man to row him across. Appearing upon the scene, he was dumbfounded, yet relieved, to see it was "the boss" who had supplanted him; and on critically inspecting his work, declared admiringly, "Weel, sir, you are a hahndy mon!"

Trees, vines, and bushes were soon growing around the stone house and it was not long before it had a settled, homey look; the work indoors consumed the time of the busy housewife, while the outdoor work engrossed the happy husbandman.

When at last his house was done, he wrote Myron Benton, whose advice as an architect he had frequently sought: "My place doesn't look so well from the river, but, what concerns me more, the river looks well from it." Yet through the years there have often been times when he wished that he had planted his house by a smaller stream; for then he could have made a companion of it, walked with it, and lounged on its banks. Often when callers expatiate on the glories of the lordly Hudson as seen from the summer-house, or other vantage points at Riverby, he acquiesces only half-heartedly, sometimes pointing out to them its chief fault: "It is a long arm of the sea, and keeps me at arm's length." Clearly the Hudson can never flow through his affections as would a lesser stream, for example, the Pepacton of his boyhood home.

Nevertheless, he has, throughout the six and forty years of dwelling by the river, had much companionship with it. It has been the great highway for the migrating birds. Many a spring morning he has seen a line of swan, or a harrow of wild geese, above his barn, or high against the 
sky on their way North- "an express train for Labrador." In fancy he follows these migrants as, launched for an all night's pull, they sail the aerial seas, swaying this way and that, en route for Hudson's Bay.

The living, wide awake river has yielded him much, even if not the closer companionship of a smaller stream. But in December he regards it with dread, when Winter pulls an icy coverlid over it, and one hears the enchained giant moaning and groaning in his long sleep.

Watching the harvesting of the ice on the broad white fields of the river has afforded him many an interesting hour. Sometimes two hundred men and boys are busy there, marking, planing, scraping, chiselling, and hauling in the ice. Even the big ugly ice-house below Riverby has times of being the centre of attraction-when the elevators are in operation and the huge crystal blocks, in pairs, slowly ascend in unbroken procession. And many a happy hour he has had skating on the river, alone, or when his son, Julian, was old enough, skating there with him, gliding exultingly over the great expanse.

Best of all is the ice-boating, whether seen from the shore, or when lying at full length, wrapped in blankets, on the low broad platform.

Mr. Burroughs calls the ice-boat a disembodied yacht, a sail on skates. Its speed is more than a mile a minute. Leaping like a greyhound over the ice, it clears wide crevasses at a bound, yet can be brought up to the wind so suddenly as sometimes to send its passengers skating on their noses.

It is always a glad time in the spring when the river slips off its icy fetters and becomes a free flowing stream. The event is preceded by cries and groans, as the river-god 


\section{8 JOHN BURROUGHS-BOY AND MAN}

stirs in his shroud. Later it is a wild chaotic scene when the ice-floes jostle and crumple against one another. Sometimes the river steals a march on you. On a bright morning in late March or early April, you may see only the white motionless expanse that has stretched below you all winter; and then, chancing to look again, you see the sparkling, moving waters-the river is born anew!

Late in March when the ice is breaking up in the river, our Fruit Farmer's thoughts turn to sugar-making. There on the brow of the hill overlooking the river, midway between The Nest and the Bark Study, at each spring's return he builds a fire under a large rectangular pan and boils sap gathered from the scattered maples, almost feeling himself a boy again in the old "sap-bush" in the Catskills.

Then come the bewitching April days, when the rye greens on the slopes and the buds swell, when he finds the first flowers, the first nests, and when the first shad come up the river; days when, as he says, the door of the seasons stands open, giving us a peep beyond. Sparrow days! Days when robins laugh and carol and run on the grass, when Downy drums, and meadow larks and flickers call; days when the soil calls for the plough, the garden for the spade, the vineyard for the hoe; when arbutus from the woods calls also, and her devotee responds, even though the vineyard is calling simultaneously for the hoe; there under the evergreens he finds her peeping out from her leafy covering; finds the bloodroot along the' lanes, the young one folded in the leaf, "the bud emerging like the head of a papoose protruding from its mother's blanket." On these magic days he hears the long-drawn-out and trilling song of the toad, and the piping hylas in the 
marshes. In fact, in spite of work in garden and vineyard, he manages to be on hand at most of the thrilling acts in Nature's varied drama.

And it has been these and countless other invitations on every hand, recurring with the seasons, that have been the forerunners of the long list of nature books published throughout the years since our Fruit Farmer settled down contentedly in his home by the river, deciding to "let the empty artificial world go by." Still, in his solitude, during those early years, he was often hungry for companionship, especially craving some one to talk books with; but consoled himself with the thought that he had the birds, and that one couldn't have everything. And then it was not long before his son was old enough to share his saunterings.

In those years before the schools and clubs and hosts of callers found him out, there was leisure to saunter and dream and write, and still have time for work in garden and vineyard. All the long list of his books, except the first three, have been written since he has dwelt at Riverby. Walt Whitman used to visit him there, and other literary men from our own country, and from Great Britain, came in those earlier years.

At that time his writing was bringing in very little money. His fruit farm, helped out by the few hundred he earned as bank examiner, was his chief source of income. And yet, though busy with his few acres, he managed many an excursion away from home. He went to the Centennial, to the oil regions of Pennsylvania, to Canada, made occasional visits to the large cities, visited Whitman in Camden often, visited often his old home in the Catskills, made his summer voyage on the Pepacton, camped in the Maine woods, in Snyder Hollow, on the Rondout, 
at Furlow Lake and on Auchmoody Pond, with Myron Benton and Aaron Johns, with Richard Watson Gilder, and others.

In 1881, he built himself a little detached study on a bench of land a dozen or more rods below his dwelling. The Study commands an extended view of the river-a little one-room structure, covered with chestnut bark, whose walls are lined with books. It has a huge cobble stone chimney. Wide windows look out upon the river. From the tough native oak he fashioned its simple furniture. Here with books and open fire, the river, and the birds in the nearby trees, he has loafed and invited his soul, and written many of his earlier books. Shortly after completing his Bark Study he wrote to Benton:

Come over, and like two mice we will nibble away on such cheese rinds as my poor board, literary and other, offers. I am alone with my books and my thoughts, beyond the orbit of household matters. I have the solitude of Bruin in my den, and suck my paws pretty industriously.

Fresh fields were soon to be explored. In the spring of 1882, in company with wife and son, he sailed for Scotland. He visited the Carlyle country, and the homes of Burns and Wordsworth. In Tennyson's country he sought the nightingale, but saw neither Tennyson nor the bird, though William Sloane Kennedy, referring to his "Hunt for the Nightingale," has said that Mr. Burroughs got more out of not hearing the nightingale than most of us would in hearing it.

From the Auld Brig of Doon, across which Tam o' Shanter rode, he wrote to Benton of the impression made upon him by the scenery as they entered the mouth of the Clyde, saying he expected to carry it with him to the other world-if he should carry anything there. Coming 
from the wilderness of the ocean into a paradise of green shores, with trees, birds, flowers, cattle, sheep, and castles, the tender beauty and repose of it all delighted his soul.

One day in the woods near an old castle, he encountered a young Scot with whom he began conversing about the birds. From European birds, the talk drifted to birds of America, and what was his surprise to hear the Scot quote his own name and some published statement of his concerning the birds! Imagine the surprise of the Scot when he learned that this stranger was John Burroughs!

In the years following we find $\mathrm{Mr}$. Burroughs writing to friends that he is getting more and more like a turtle and wants to crawl about in his own little field, and yet, in tracing him in his frequent jaunts from home we see that he has not been so very closely confined to his own little field. He camped on Slide and the Wittenberg, visited Walden Pond, strolled the beach at Ocean Grove with Whitman, occasionally went to Smith and Holyoke for walks and talks with the students, journeyed to the Blue Grass region and the Mammoth Cave, to Niagara Falls and the Middle West.

The year of the triple eights found our Fruit Farmer increasing his acres, making with the new purchase, twenty in all, after which he engaged in grape-growing on a larger scale. He set out more Concords, Campbell's Early, Moore's Early, Delawares, Niagaras, and some fancy varieties, more than twenty-four hundred vines in all, besides two thousand currant bushes between the vines, and two thousand hills of raspberries.

In the work of clearing the land, draining it, blasting out rocks and stumps, and setting out the vines, he found a new delight. His health was better, his sleep 


\section{JOHN BURROUGHS-BOY AND MAN}

sweeter. He wrote with enthusiasm in his diary of how he had soaked up the sunshine till he glowed all over; how his whole being had had an earth bath, and there was a feeling of freshly-ploughed land in every cell of his brain. The hoe handle seemed better to him then than did the pen.

And after that, for several years, the "grape war" absorbed the major part of his time. There were posts to set out and wire to string; there was ploughing, fertilizing, spraying, trimming, tying up, pruning, and harvesting. In all this work he, of course, had help, but for many years bore an active part himself, his writing then confined chiefly to the late fall and winter months. Still, the saunterings, and the reports of them, grew into essays, and the essays grew into books.

At Walden Pond, Thoreau had made the earth say "beans." At Riverby, John Burroughs has made it say "grapes," and "currants." Thoreau's venture had been engaged in chiefly that he might brag to his neighbours of his economy, but the aim of John Burroughs was to support himself and family comfortably, send his son to college, and make enough from his fruit farm so that he might write when and what he pleased, regardless as to whether his writing brought him any very considerable addition to his income. He realized this aim. Forty tons of grapes was the average yield for many years and the Riverby grapes always found a good market.

After the vineyards were well established, there was the routine work in which "Hud" and the faithful horse were indispensable; and as Julian grew up he, too, took his turn at anything and everything a boy could do. The spraying, which began in May, had to be continued every two weeks 
till harvest time-to combat the "black rot." The summer pruning, a tedious job, consisted of disentangling the vines and pinching off the ends of the new shoots. In midsummer crimson clover was sown, and later ploughed under, to supply nitrogen; and in winter they trimmed and tied up the vines and kept up the supply of crates.

Rain storms, hail, drought, and the birds often played havoc with the grape crop. The orioles, who stole so many grapes, and pecked so many that they did not steal, were bold in their thefts. But the boys in the neighbourhood, and skilled grape-thieves across the river, made sadder inroads than birds or rain or hail.

One day, on finding the vines stripped in places and a wasteful mess of grapes upon the ground, the Fruit Farmer decided to learn, if possible, who was the thief. Putting on a long black oilcloth coat, he went out and lay in the shadow of the vines. It was a warm moonlight night and he fell asleep. Awaking suddenly, he sprang up just as a boy, coming in at the end of that row, saw him rise from the ground. Terrified at the sudden appearance of that strangely arrayed figure looming up in the moonlight, the boy rushed forth and tried to scramble over the stone wall, but was grabbed by his pursuer. In wrenching himself away the culprit nearly tore his trouser leg off, but let out such an unearthly yell that his captor, startled, let go his hold. Up the road rushed the frightened boy, and up the road went the Fruit Farmer. At the top of the lane, seizing his bicycle, the culprit started to ride away, but on looking back and seeing his pursuer hot on his heels, wobbled, lost his hat, tumbled off, and fell down in a heap; but scrambling up, abandoning wheel and hat, he scooted for dear life. 


\section{JOHN BURROUGHS-BOY AND MAN}

The next day a sheepish-looking lad appeared at Riverby and humbly said, "Mr. Burroughs, may I have my hat and wheel?" He declared he had never been there to "swipe" grapes before, and never would try it again. He confessed that when he saw that dark figure rise from the ground, and felt himself seized from behind, he thought Satan had him sure. After they had had a good laugh over the fracas, the Fruit Farmer took the contrite lad down in the vineyard and, filling his hat with grapes, told him to come and ask for some the next time he was grape hungry.

One season, to protect the cherries, he placed a stuffed owl in his trees. Such a racket as followed! Orioles and robins shrieked their protests. The news spread, and every bird around Riverby came to see and scold the owl, and as every bird carried away a cherry, he lost more than he gained by the ruse. Next season he tried a different means of outwitting the birds: Rigging up the dinner-bell in one of his cherry trees, he reversed the usual order of thingsits clanging was not to summon to a feast, but to cut short their repasts. Chuckling to himself, he sat in the shade holding the string attached to the bell, and pulled it vigorously whenever he saw a bird enter the tree. The neighbours, hearing the frequent peals of that bell, thought they were having a perpetual feast at Riverby. By this means he actually saved enough so they had some cherry pies, and Mrs. Burroughs's cherry pies were worth scheming for.

For years Julian and his father had roamed the woods and swamps in a wild, picturesque region back in the hills, more than a mile from home. The Old Silurian rocks, the primitive forest, the waterfalls, and Black Pond held many a lure for boy and man. Finally there came a time when, 
wearied with the noise of steamboat and railway, the broad expanse of the Hudson, and the routine and exactions of domestic life, the dweller by the river craved something more primitive and homely than Riverby offered-"something with the bark on"-so decided to build a retreat in that secluded place.

His farmer's eye saw that if that rich swamp land, once an old lake bottom, were drained and cultivated, the wilderness would blossom into garden produce. Amassa, a young farmer, eagerly undertook the task, Mr. Burroughs advancing the money for the hundred acres and taking a portion of them in part payment, the twenty acres he reserved forming the now well-known Slabsides region.

In 1895 the land was bought. Then they made a road over the mountain, prepared the land, and built the cabin. They blasted through the rim of rock, drained the land, dug up stumps and roots, cut off the undergrowth, pulled out weeds and vines, and burned the rubbish. Skinning the swamp, as it were, they took off more than a foot of it, getting down to the rich black muck. A pine log, sound and hard, was found deeply buried in the muck, having lain there probably since Columbus discovered America. Sticks cut by beavers, some cord wood, a stone bottle, and a wooden mallet were found many feet below the surface. After it was cleared and drained, and ploughed and harrowed, the soil looked like velvet, and in due time long green lines of celery and lettuce gave a touch of the domestic to the wild, untamed region. With the help of a good carpenter Mr. Burroughs hewed the trees and built his homely cabin, building it on a rock on the edge of the swamp, the rugged, verdure-clad cliffs partly encircling it. The cabin looks much like a log cabin. It is built of 


\section{JOHN BURROUGHS-BOY AND MAN}

slabs, or the first cut off the logs, the bark being left on. The roomy veranda with rustic railing, shaggy cedar posts, and sloping roof, and the great stone chimney add to the picturesqueness, while the clambering woodbine lends beauty to the rugged exterior. On the wide rustic door is a latch-string, and a curiously twisted knob for a handle.

The bark was also left on the beams and rafters of the interior, but the little wood-borers have since removed most of it, leaving their delicate traceries instead.

The cabin is a two-storied structure. The planed boards of its inner walls have the seams covered with split birch saplings. A satiny yellow birch partition partly divides the one room below into living-room and bedroom; stairs lead to the loft where there is a comfortable bedroom and a roomy attic. In one corner of the living-room is a window-seat with books and writing table; in a niche under the stairs the dining table is placed; in another corner is the culinary department-cupboard, washbench, a table with the oil stove, and an array of kitchen utensils.

The bedsteads are built of birch limbs with the bark on, and most of the furniture is home-made, the legs to tables, stands, and window-seats have a curiously twisted effect due to the climbing bitter sweet winding about the sumac limbs.

In looking about the sparsely furnished cabin the visitor sees that his host is untrammelled by things. Old blue coverlids, which grew on the backs of the Roxbury sheep, are on the beds, patch-work quilts, pieced by his mother, upon the cots, and carpet rag rugs upon the floor. From a swinging crane in the wide fireplace hangs a smoky iron tea-kettle, and on the wide stone hearth are old-time andirons and tongs. Some clever maiden has appropriately 
embroidered an oven bird on a mahogany-coloured holder that hangs close by. Trophies from the woods, birds' nests, and other natural history specimens are on the stone mantel, and the rustic book shelves are overflowing with books.

When the little mountain retreat was finished, its builder, wondering what he should name it, considered Crag Foot, Rock Haven, and Echo Lodge, but when a neighbour suggested "Slabsides," he at once "cottoned" to that, and Slabsides it has since been called.

When it was ready for occupancy in April, 1896, its owner and his brother Hiram moved in and began their simple house-keeping, dwelling there in contentment in the spring, summer and fall, for the next three years. Hiram pottered about with his chickens and his bees, his brother did the simple cooking, dreamed and roamed the woods, and wrote when the mood for writing came. Coming in with his hat full of eggs which he had gathered from the nests on the rocks, Hiram would sit by the hour near the hearth, drumming softly with his fingers on the arm of his chair. Silly Sally purred on the hearth, or on her master's lap, when not engaged in her pursuit of the birds, and often for hours at a time the three sat together in quiet, wordless companionship.

Daily walks down to the post office, and to oversee affairs in the vineyard, perhaps to levy on the larder at Riverby, kept the Hermit of Slabsides from being too much of a hermit in this retreat.

Often as he sat on the veranda in the sweet solitude, watching phœbes and bluebirds building near, he would exclaim, "Blessed Slabsides! it is indeed a house of refuge to me!" There he listened to the mournful plaint of the 


\section{JOHN BURROUGHS-BOY AND MAN}

turtle dove, the love notes of the chickadee, the song of the shy water thrush. In the spring twilights he heard the hoot of owls and calls of whippoorwills. He had occasional calls from a partridge and her brood. Some mornings on a dead pine tree on the cliff above the spring, he would spy a bald eagle sitting and preening himself, his white head gleaming in the sun. In the leafless woods arbutus shyly peeped at him, bloodroots and liverworts smiled, Jack in the pulpit preached daily sermons, and in the distant bogs, the regal cypripedium compelled his homage. Joyous days! and fruitful of much besides what was passing from dawn till night; for in that sequestered place many of his books were first lived by the man, then later translated by the writer to the page.

At about this time he began to slip off some of the burdens from his pack, turning much of the vineyard work over to others, loafing and inviting his soul more and more, and with the happy result his readers know. At this time, too, people began to hunt him out in his woodland retreat. The way to have people seek a thing is evidently to hide it. No sooner had he got nicely hidden away in the hills than visitors from far and near began to come, friends and strangers, the renowned and the obscure, students, writers, artists, photographers, lecturers, reporters. They came singly, in pairs, in groups, in clubs, in schools. It is doubtful if there is a literary landmark in our country that has had so many visitors as has Slabsides; and those who have tasted its homely hospitality can well understand the appropriateness of the Indian name given to their host by a clever guest-Man-notafraid-of-Company. First to come of all the clubs were 
members of the Wake Robin Club at Vassar; their annual picnic and woodland ramble with the Sage of Slabsides is now a time-honoured institution. On a certain day in May Slabsides is afloat with pretty girls. Inundating his cabin, they sit at his feet before the fire if the day is cold, or, if fair, follow his lead through the woods. Countless other clubs and schools have followed suit, until now, on any fine Saturday or Sunday in spring, early summer, and fall, merry flocks of girls and women, and often boys and men, may be seen wending their way along the country road and through the woods to Slabsides. It is often Hamlet with Hamlet left out these later years; they by no means always find the Hermit there, for it has been many years since he has dwelt at Slabsides, nowadays only going up there for an occasional hour of solitude, or for a picnic with his friends.

Along with the hosts of visitors, there came frequent demands to lecture before schools and clubs-to give informal talks on birds, or other phases of nature; and for a time in the late eighties and early nineties he yielded to these requests; till, finding it too much of a task, he declined all further inducements, thereby gaining leisure for the things he really wanted to do. As his pen has grown more and more productive, on the advent of each magazine article and book, his readers have sought closer personal relations with him, through correspondence, and in pilgrimages to his home.

John Muir was one of the earliest Slabsides guests. Thither he came on one of his trips to the Atlantic coast. He was rowed across the river by his host and son, and entertained, as he preferred, in the rustic cabin, rather than in the fine stone house at Riverby. There at Slab- 
sides, till far into the night, before the singing hickory logs, John of Mountains sat and talked to John o' Birds, and to Julian; talked of his wanderings in the high Sierras, and in Alaska, and told them of his dog, Stickeen, and their perilous adventures on Alaskan glaciers. Then, after basking awhile in the friendly eastern woods, he went back across the continent, to his Red Woods and his mountain fastnesses in Yosemite.

One day many years later (to jump ahead a little) President and Mrs. Roosevelt came up the Hudson in The Sylph and spent the day at Slabsides. It was a hot day in July. The tramp along the road, then the steep climb through the woods, was the sort of thing the Strenuous One liked, and Mrs. Roosevelt was "a good sport," too. Up they climbed, the shorter and steeper way, the President talking with his accustomed vigour, and mopping his forehead as he followed Oom John up Breakneck Stairs. Nothing halted them in their rapid march but an orchard oriole, and a yellow-breasted chat, to which they gave the countersign, and passed on.

They were charmed with the quiet and simplicity of Slabsides. "It seems so good to get away from people," said Mrs. Roosevelt- "Oyster Bay is as bad as Washington." The President browsed among the books, explored the cave where the butter was kept, and brought fresh water from the spring, pronouncing it the best he had ever drunk.

While Mr. Burroughs was preparing dinner, he attended to the lively and varied talk of the President, putting in a few words now and then, but not to the detriment of his task. He placed the potatoes and onions in the ashes to roast, dressed the broilers, and in due time broiled 
them over the coals. Mrs. Roosevelt and Julian shelled the peas. Amassa brought in lettuce from the muck garden, and they had a huckleberry pie which Mrs. Burroughs had sent up from Riverby.

Shortly before dinner, some reporters, who had got wind of the event, suddenly appeared in the clearing, hot on the President's tracks, puffing and mopping their brows, but looking triumphant at having stalked their big game so successfully. But their quarry, scenting their errand, called out: "No, Gentlemen, I have nothing to say to you. Good day!" And as they climbed up the steps at one end of the veranda, he, waving a farewell, went down at the other end and off into the woods. Mr. Burroughs explained that the President wanted this one day free from the Public Eye, and, somewhat mollified, they put up their fountain pens and disappeared beyond the trees.

A neighbour from one of the nearby cottages also came bouncing in. The President regarded her sternly until, learning that she was just a neighbour, his sternness changed to affability. She stayed long enough to prepare their salad and to get his autograph, then slipped away.

When all was in readiness, they sat down to the oilclothcovered table, with appetites well whetted from having watched the preparation of the meal. Roosevelt ate like a soldier, jumping up several times to help himself from the tin dipper-the glass of water at his place proving entirely inadequate. He told of a guest being asked by his hostess if he was hungry.

“ 'No, Madam, I'm not hungry-I'm greedy.' Well, that is my case to-day," he added. 
He was full of anecdotes. He told of a friend upbraiding him for some grievous mistake in public life which he had made, and of his reply: "My dear fellow, where you know of one mistake I have made, I know of ten-" a thoroughly Rooseveltian way of disarming a critic.

A friend of Mr. Burroughs, a Congressman from Poughkeepsie, was there also. The President talked politics with him, and natural history with Julian, quoting to him things from his (Julian's) father's books. "I've read them so much I could pass an examination in them," he declared.

Mrs. Burroughs drove up in the afternoon to greet the distinguished guests. Dressed in her best, as though to compensate for her husband's old clothes and the homely rusticity of Slabsides, she invited the guests to Riverby for ice cream and cake, and took Mrs. Roosevelt back with her in the carriage, the others following behind.

The entirely different scene at Riverby interested the guests. They admired the river view, the handsome wellappointed stone house; praised the housewife's immaculate kitchen, and enjoyed their ice-cream in the breezy summerhouse. The President glanced rapidly over the books in the Bark Study, and was especially charmed with the little brown cottage where Julian and family then lived. They had just been talking about the elegant Italian villa across the river, but when Roosevelt stepped into the big living room of the cottage, he rushed out, calling "Edith! Edith! Come here! I want you to see this-something original and American!"

Mr. Burroughs introduced his guests to the neighbours and villagers who were lingering at the dock as they boarded the yacht, and Roosevelt in his happiest mood 
greeted each with a personal word-even the little girl with her pet kitten in her arms.

As The Sylph slowly moved away, Mrs. Roosevelt stood, serene and smiling, while the President waved his broad panama and shouted, "Good-bye, Oom John! Good-bye! We've had a bully time!" 


\section{CHAPTER XV}

\section{DOG FRIENDS AND A BOY CHUM}

IT may be said of John Burroughs as Froissart said of Count De Foix, "He mightily loved dogs above all other animals." He often says of himself, "I can look in the face of an ugly dog and win him, but with an ugly man I have less success, and with an ugly woman-I would turn and flee."

I have seen him make friends with an ugly and crabbed Chow who savagely repelled overtures from all others; have seen his neighbour's blind Rover jump about joyfully on hearing his voice, forsake his owner and follow Mr. Burroughs in blind devotion. The latter could not sneak by the house but that Rover knew his step, and would follow him to Slabsides. I have seen a wet, bedraggled strange cur steal into a room where Mr. Burroughs was sitting with several others, all equally strange; seen the cur go straight to him, climb upon his lap in spite of his protests, and settle down there, sure of his welcome, the protest insensibly merging into gentle chidings, and then into caressing tones, as the wet dog, unabashed, turned around and cuddled down upon his knees. Yes, he has mightily loved dogs, and they have mightily loved him.

In those first days at Riverby, before his son was old enough to be his companion, Mr. Burroughs had a dog, Rab, the light and life of the home, who shared his work 
and play; just a common cur, a mixture of black and tan terrier and mastiff, he yet had an uncommon amount of canine intelligence and devotion. The incarnation of youth and adventure was Rab-a walking holiday, as it were, and he and John Burroughs were boon companions.

But the companionship was brief, only a few months. Rab got the dog distemper and, though seeming to recover, succumbed after a relapse. With what tenacity, though, he clung to life! For two days and nights they watched over him before release came, but even when too weak to lift his head, he recognized the voice of his master.

Rab's grave was made beside the flat rock that leads to the spring, and at its head his master placed the crooked staff which he had so often carried to the woods on their rambles. Carving Rab's name upon it, and the date of his passing, he said on thrusting it into the ground, "There, Rab! my staff shall be your monument. I shall not need it again this summer. I shall walk alone and staffless hereafter in the lonely woods." And leaning on his hoe handle, he looked across to the hills beyond the river, tenderly musing on his faithful friend.

Rover, whom he rechristened Rose Mary Rose, though not because of any real claim to the girlish name, was his next dog friend, the companion of his walks for two or three years, a spirited black and tan of good breeding, a slender dog with a tail like a rush, and a tongue like a roseleaf. Says Mr. Burroughs:

As soon as I would begin to harness the horse, Rose would begin to bark like mad, and circle around the place. Finally, getting rid of his superfluous joy, he would sober down a little, and off we would start. If he saw me putting bread and grapes in my pocket, he knew that meant a trip to the woods and a joyous adventure. 
Rose liked the woods better than the river. Once when they were out in a rowboat, the river being rough, a queer expression came over his face. He looked as though he were going to laugh; instead, up came his dinner, and a more forlorn-looking dog for a few minutes never wagged a tail.

It was Rose of whom he often speaks as "the hero of the Battle of Lundy's Lane." Although naturally peaceable, he could defend himself if need be, and when one day as they traversed the lane of Neighbour Lundy, two common curs came out and pitched into him, Rose, supple and spry, cut out right and left, and whipped them both, routing them-with his master's help. "He and I came off victorious. I told him I would erect a monument to him to celebrate the battle."

Poor Rose was poisoned by some boys who said that he bit them. "I laid him on a little bed at the foot of the stairs, and there he died. I kept him a day or two in his little bed, then buried him under the old gill-flower apple tree."

Lark was the next dog, the most gentle and affectionate of them all; an unsophisticated little mongrel, a short, shaggy, black and yellow dog, with a curiously-shaped head:

I had first seen him with a man on the streets of Poughkeepsie, where we scraped acquaintance. He took a shine to me and I to him, so I gave the man two or three dollars for him, and we came home together -a happy pair!

Lark was a little fellow. Many's the time I have carried him on my shoulders when the snow was too deep for him in the woods. He was my muse and the inspiration of all my walks. The "Notes of a Walker" are mainly his. He would sniff out the fact and I, as his secretary, would chronicle it. He hunted bees with me. "The Idyl of the Honey Bee" is Lark's as well as mine. He used to ride in the buggy with me 


\section{DOG FRIENDS AND A BOY CHUM 297}

on my trips to Roxbury. As he would sit on the seat beside me, he would unburden his mind threateningly to every dog we passed, but if I put him down on the ground, he would shrink back and seem to say, "Oh! I don't want to fight! I don't want to fight at all." I used to tell him his tail was a flag of defiance in front, and a flag of truce behind. He couldn't kill a woodchuck-couldn't kill anything. He had no more fight in him than I have. He was a pacifist through and through.

I remember one day as we were coming home from the woods, I saw that Lark had something cornered against a stone wall.

"What have you got there?" I asked.

He danced and barked in glee. His prey was behind a flat stone that rested against the wall. He barked as much as to say, "You pull down that stone!" I did, and Lark received in his face the charge from the masked battery of the enemy in black and white uniform. Crestfallen, we went home, but the news got there before we did and for a long time our room was better than our company.

When Lark died, his master mourned him deeply, writing Myron Benton that he doubted if he should ever give his heart to another dog-it was too painful to be widowed in that way. And Lark was laid to rest with the others beside the old drift boulder.

When Julian was a very little fellow his father used to amuse him by making up doggerel about his dogs:

Hark to the tale of my dog, Lark!

He can bark after dark, And hit the mark

Way over to Hyde Park.

There was a longer, never-ending one about Rose:

Rose Mary Rose,

Just you suppose,

When the wind blows,

And down come the snows,

You should kick off the clothes

And thus expose

Both your nose and your toes

Until they were froze. . . . 


\section{JOHN BURROUGHS-BOY AND MAN}

By this time the child would stop up his ears and plead, "Oh, Papa, stop! stop!"

Laddie and Ino were two dogs which he had at the same time. Ino, a big shaggy black dog with a white breast, was a cross between a setter and some common breed. He was the companion of Julian as well as of his father. Whenever Mr. Burroughs would return from his trips of examining banks, Ino would be at the train to meet him, always so relieved on catching sight of him; but one day when Ino went as usual to the train, his master disappointed him, and Ino, hanging around the tracks, got run over by the cars.

Laddie was a mixture of water spaniel and black and tan, with bristly hair. He and his master once had an exciting adventure on the river ice toward spring. They started to go across to Hyde Park, but the ice being very brittle, they were in great danger of breaking through. While picking his way across, chancing to look up, Mr. Burroughs saw Laddie running for dear life toward the shore, while the shore itself was apparently going down stream very fast. The ice-harvesters had cut a canal twenty feet wide to the opposite shore, and the flood-tide was carrying the whole body of ice up the width of that canal. The ice moved up only twenty feet and stopped. Seeing that when the tide turned, the whole body of ice would go down the river, Mr. Burroughs said, "Laddie, we must leave our errand undone, and go back home as fast as we can." His own knees were shaking, and Laddie was trembling piteously, saying as plainly as a dog could say, "Dear Master, I beg of you, don't go back across the ice-don't-but if you do, I'll have to go with you."

There was no time to lose, and disregarding Laddie's 


\section{DOG FRIENDS AND A BOY CHUM 299}

entreaties, he again embarked on the ice, Laddie following closely. It was ticklish business, but they gained the home shore in safety. An hour later, away went the ice down the river, leaving a great smooth open space from the shore.

Laddie's fate was a sad one. He followed the butcher off one day, was attacked by a big Newfoundland dog, and died of the wounds:

When I came back and saw him lying there, wounded, and all but dead, I cried, "Oh! Laddie, Laddie!" and all his wounds started and bled afresh. He knew my voice.

And, though so many years have passed, as Laddie's master speaks of this, the sorrowful voice is choked, and the eyes fill with tears.

"Rab and Rose and Lark and Laddie," he repeats tenderly - "There they lie under the sod. They filled a need in my life. It seems as if it had been in some other world -the dear things!"

Nip, the last dog he ever had, was a fox terrier, white with a short tail, and a black spot on one eye and ear. He was given him by Mrs. Vanderbilt, his neighbour across the river.

One October day as Mr. Burroughs and Nip were going across the railroad bridge over Black Creek, as they had gone a hundred times before, Mr. Burroughs stopped at the end of the bridge to look down the creek. Nip stopped, too, looked about, and, somehow, forgetting himself, slipped off the tie and fell through, striking some fifty feet below on some stones.

He got up and ran crying a few steps, then fell over in his death agony. His master was stunned. It was one of the worst shocks he ever had, and for a few minutes the 
whole universe seemed bereft. Going down the steep bank, and lifting the limp body of his little friend, he placed it near the abutment of the bridge, and went sorrowfully home. All through the night he dreamed of Nip, and the next morning, carrying the lifeless body home in a basket, put it before the fire, craving to see him once again in his old place, before the earth should hide him forever from sight. On making his little grave near Slabsides, he felt in burying Nip that he was burying a part of himself.

Although he has cherished certain cats also, they were never as beloved as his canine friends; still Nig, Tom Tinker, and Silly Sally held warm places in his affections, in spite of the diligence they showed in pursuing the birds. Silly Sally, especially, was an ardent ornithologist. No matter how much he remonstrated with her because of her taste for birds, she pursued them with unabated zeal, and when, at last, old and decrepit, she went to the happy hunting-grounds where cats in time must go, he vowed he would have no more pet cats.

Nig, too, was a pet that would bear watching. One day as the Fruit Farmer was sitting in the summer-house with Nig on his knee, he saw Stripe Coat come out of his den in the side of a bank near the Study. Pausing in its doorway, the little rodent glanced nervously about, leapt to a tussock of grass, put up one foot appealingly, then scampered away to a friendly pile of grape-posts down below. Nig saw Stripe Coat quite as distinctly as did her master, and jumped to the floor, but at his sharp command sat down demurely and folded her paws, regarding the chipmunk dreamily.

Shortly after, the master being called to the house, Nig 


\section{DOG FRIENDS AND A BOY CHUM 301}

improved her opportunity: as he was starting back, he met her coming toward him with Stripe Coat hanging limp from her mouth. Angered, he rescued the victim and reproved Nig roundly. The little creature lay as if dead in his hand, though showing no marks of the cat's teeth. Soon it gasped and its heart began to beat perceptibly. Though Nig had choked it, it had been saved in the nick of time. He put it down by its door and watched till it had crawled inside. Later, calling to express his sympathy, he left some corn to atone for Nig's cruelty. Before many days Stripe Coat was travelling her accustomed ways, though warier than ever; and in the summer four baby Stripe Coats emerged from the little round doorway and frisked about in safety, for then the great black monster with the green eyes had gone where it could trouble them no more.

At a very early age Julian became his father's comrade, indoors and out. His father recited nursery rhymes to him, read him fairy tales, told him stories, and later read him many a tale of adventure and travel. It was hard to tell which liked best the rhymed tales of Robin Hood, by Howard Pyle; then there were the stories in Wide Awake and in the Youth's Companion; the Jack Hazard series by Trowbridge; $C a b$ and Caboose by Kirk Munroe; Dana's Two Years Before the Mast; and the First Crossing of Greenland-to name a few of their favourites. And day by day, they read together in "Nature's infinite book of secrecy."

His father shared the lad's activities; helped him tame his various pets; make his fish nets, and the keel to his boat; went with him scapping for herring on the river; snaring for suckers, and ducking on the Shattega; and 


\section{JOHN BURROUGHS-BOY AND MAN}

rowing and skating on river and pond. Together they sought the first spring flowers, hunted birds' nests, and traced the footprints of wild creatures in the snow. Together they tamed Molly Cotton-Tail, played fostermother to a young marsh hawk, and danced attendance on their pet 'coon. He taught the lad how to make basswood whistles and cat-tail penholders, and the lad taught him many things that he learned by himself, and others found in studying The American Boy's Handy Book. They fished and hunted together, and went in quest of wild honey. The joys of the wild creatures were their joys, the tragedies their tragedies. One day when Julian was a very small lad, he came in with a pitiful tale: He had seen a blue jay in one of the spruce trees, close to the nest of a vireo, and right while he was looking at it, the robber swallowed a just-hatched bird. As distracted as were the parent birds themselves, who snapped their beaks almost in the jay's face, the boy ran with the cruel tale to his father.

When quite a little chap, Julian discovered, as had his father before him, that the white-faced wasps were stingless, and used to amuse himself by showing the other boys how he could "tame" wasps so they wouldn't sting him. Boldly handling the harmless creatures, he would chuckle to see the others looking on in wonder, as the impotent wasps would go through all the motions of stinging, yet leave him unharmed. He never put the other fellows "wise" to the trick.

What days they had skating on the long still stretches of Black Pond! In the light covering of snow they would read the records of the wild creatures - a fox, a rabbit, a muskrat-gathering much from the tell-tale footprints. 
One day they came upon a strange track in the snow, about the size of a dog's, and traced it to the head of the pool where the creature had taken to the open water. Ugh! what a cold bath! It proved to be the little otter, rare in that locality, which tracks fish through the water as a hound tracks a fox over the hills.

One morning Prince was missing from the pasture and Julian and his father started out to find him. On coming to the highway, they asked each other:

"Which way - up or down the road?"

Thinking they saw a horse's track going down the road, they followed it, but presently on coming to where the road led through the woods, Julian, ahead, called out:

"Papa, Prince hasn't gone this way-see the spider's web across the road!"

"Good for you, my boy!" said his father, delighted at the lad's keen observation and correct deduction. "You've got eyes instead of buttons in your head!" And turning back they soon found Prince in the opposite direction.

Once Julian and his father tracked a weasel to its den on the edge of a tamarack swamp. Trying with mattock and shovel to dig the weasel out, they nearly got lost themselves in the maze of tunnels which they found, and, although handling a ton of earth over two or three times, they could not come upon the store-room where the creature had put all the mice and moles which they had watched him carry into his den.

One season they found a marsh hawk's nest in the Slabsides region, and as one of the young hawks was in danger of being starved to death, Julian brought it home, reviving it with warm milk by means of a fountain-pen filler. He 


\section{JOHN BURROUGHS-BOY AND MAN}

kept his uncanny pet in a pen in the Bark Study. It had an old shrunken look, and for a time was helpless indeed. But not long and it was swallowing bits of meat, and soon eating ravenously. It kept up a sharp whistling-except when asleep! Though preferring mice, birds, and squirrels, it would accept butcher's meat. Julian was kept on the jump to supply the demands of his voracious boarder. He trapped and hunted and enlisted all the boys in the neighbourhood; even robbed Tom Tinker of his rightful prey to feed his hawk. His usefulness as a boy-of-allwork was seriously impaired.

"Where's Julian?" his mother would ask, time and again, "I want him to get a pail of water."

"Gone after a squirrel for his hawk," or "Hunting chipmunks," would be the answer. One day, although its wing had been clipped, the hawk sailed away on the shoreless aerial seas, and his foster-parent knew him no more; but before he sailed he had devoured twenty-one chipmunks, fourteen red squirrels, sixteen mice, and twelve English sparrows, besides no small amount of butcher's meat.

As Julian and his father sat at dinner one day they heard Ino barking in a way that told them something was up outside. Something was up-in one of the spruce trees a few feet from the house. They threw up sticks and stones and soon, deep in the heavy foliage, espied a bunch of fur. With a long pole they belaboured that bunch of fur and, in time, dislodged it. It was a 'coon. A lively time followed. As Mr. Burroughs grabbed the 'coon by the tail, Ino dashed up and knocked it out of his hand. A still livelier tussle ensued, however, when, some days later they tried to put a collar on that 'coon. He proved a cun- 


\section{DOG FRIENDS AND A BOY CHUM 305}

ning pet, and Julian set great store by him, feeding him grapes, chestnuts, peanuts, and apples.

It was a sad morning when, going to the coop, Julian found the little door open and no Mr. Coon inside. He had evidently liberated himself by loosening the snap that held the little sliding door. That night the antics of Tom Tinker, and even the rhymes of Robin Hood, failed to wield their usual charm - the boy's heart was in the highlands chasing his wandering 'coon.

One day Julian called his father to the garden to see a black snake swallowing a garter snake. The little victim, though holding back with all its might, hooking its tail around the raspberry bushes, was being slowly engulfed, when the black snake, startled by the approach of man and boy, suddenly ejected his long mouthful and glided away. Although the little Jonah's head was bleeding, he had not suffered much from his short stay in the reptilian whale.

When one starts on snake tales they are likely to be longdrawn-out. A few days after that, "Hud" came down to the Bark Study and called the Man with the Pen to witness another snake contest-a garter snake swallowing a little green snake. Half of the victim had disappeared; he was almost as long as his captor, and so slow had been the process of swallowing that he was dead when they attempted his rescue.

Boys often write to Mr. Burroughs telling him of their interests and of course hoping for an answer. Now he is always glad to get such letters, and answers a good many, but it would be quite impossible to answer all of them. One day, long ago, he did answer a letter from a boy in Rochester, and months later his reply was returned to 


\section{JOHN BURROUGHS-BOY AND MAN}

him from the Dead Letter Office. Tom Brown will probably never know that Mr. Burroughs answered his letter, but perhaps some other boys will accept this as a reply to their own:

\section{DEAR TOM BROWN:}

Esopus, N. Y., June 1, 1883.

I have been a-fishing or I should have answered your letter before. I always go a-fishing about this time of year, after speckled trout, and I always catch some, too. But dog-fighting I have nothing to do with, unless it be to help some little dog whip some saucy big cur. Game birds are all right in their season, but I seldom hunt them. Yet this is about the best way to study them.

You want to know how I felt as a boy. Very much as I do now, only more so. I loved fishing, and tramping, and swimming more than I do these late years. But I had not so tender a heart. I was not so merciful to the birds and animals as I am now.

Much of what I have put in my books was gathered while a boy on the farm. I am interested in what you tell me of your Band of Mercy, and should like much to see you all, and all the autographs in that pink covered book. Well, youth is the time to cultivate habits of mercy, and all other good habits. The bees will soon be storing their clover honey, and I trust you boys and girls are laying away that which will by and by prove your choicest possessions.

Sincerely your friend,

JOHN BURROUGHS. 


\section{CHAPTER XVI}

\section{DAYS OFF}

As we have followed the farm boy, teacher and student, writer, treasury clerk, bank examiner, and fruit farmer in his several pursuits, we have found him combining work and play as few of us learn to do. When we see all that he has written about his pastimes, we wonder how he has made such a success of his work. How did he manage to keep his nose to the grindstone so much of the time, yet get so many days off? How make fruit-farming pay, as he assuredly did, yet learn so much about birds and other wild creatures?

Knowing how to use eyes and ears and keeping on his thinking-cap, is the explanation of much that at first seems puzzling. Besides, living in the country, he could kill two birds with one stcne-attend to bank examining and the vineyard, yet see things, as it were, out of the corners of his eyes, and hear with the tips of his ears; could examine the banks in the cities with care, and the banks by the roadside, where the juncos build, with equal care, and tenfold interest.

Sitting with his back to the study window one winter day, he caught a glimpse of a bird reflected in his eyeglasses, thus discovering a rare visitant, a pine grosbeak from the North, and going outside saw four others, plump and active, greedily eating the buds of his Norway spruces. It is, then, his love of animals, curiosity about natural 


\section{JOHN BURROUGHS-BOY AND MAN}

objects, and his alertness of the senses, that account for the wealth of nature lore he has accumulated while pursuing his avocation as fruit farmer and his vocation as writer. Somewhere he has told us we have to bear on with the eyes if we would discover Nature's secrets; that the tree frog, at first glance, looks like a piece of bark or a lichen; the creature called a walking-stick, like a bent twig; that the wood frog is the colour of the dry leaves over which it hops, though as dark as the pools themselves when spawning in them.

One April day on the way to Slabsides, stopping at a little pool in the woods, into which he had peered hundreds of times before, he discovered scores of creatures entirely new to him, suspending themselves in the water. They were fish-shaped, a trifle more than an inch long, semitransparent, with a dark line showing through. As they moved about by means of pappus-like appendages, their large heads and protruding eyes gave them a gnome-like look. What could they be? They were so transparent he could almost tell what they had had for dinner. Collecting some of them, he sent them to an authority on aquatic animals and learned that their name is longer than they are-Eubranchipus vernalis. The common name is fairy shrimp.

When he roams the woods, even in familiar places, $\mathrm{Mr}$. Burroughs always feels a little "peeved" if Dame Nature doesn't show him something new. One April day he had about made up his mind she was not going to reward him that time, and had sat on a rock to rest, perhaps to sulk a bit, when looking up he saw a newly-made crow's nest in a hemlock. Soon he heard what he thought were the voices of young birds, but it was only Jim Crow feeding 
Mrs. Crow. Apparently she was about to lay her eggs; and if the Crows didn't actually count their chicks before they were hatched, they were certainly having a dressrehearsal of feeding them long before the young were ready to come upon the stage. Mrs. Crow, assuming the character of a young bird, was acting timid and babyish and mimicking the voice of the young, while Jim Crow brought her food and showed a lively concern as he fed her.

In the yard at Riverby is an old gill-flower apple tree which Mr. Burroughs points out to callers, telling of the good crop of apples it has borne for fifty years, but of its better crop of birds. Of late there has been a falling off in the yield of apples, and the old tree is now a mere shell, but there's no falling off in its yield of robins, woodpeckers, and bluebirds.

Long has it been the stage-setting for many a comedy and tragedy in bird life. Many a fight has Downy and Blue Coat had over their right to the limelight on that stage. Many a tussle have the feathered tenants had over the priority of their leases. The English Sparrow would eject Blue Coat whenever he would try to take possession, then the Fruit Farmer would eject Johnny Sparrow and invite Blue Coat to come back and make himself at home, rent free. Downy and Hairy Woodpecker live peaceably enough in the old tree, excavating their retreats in the fall. In going up to the house from his Bark Study John o' Birds often stops and raps good night to Downy who puts out his head for a hurried answer and hastily withdraws.

The boys at West Park, knowing that Mr. Burroughs is interested in everything out of doors, often "put him wise" to things they discover in the vicinity. Sometimes 


\section{JOHN BURROUGHS-BOY AND MAN}

they get the start of him and report arbutus out before he has heard her calling; or they tell him the woodcocks are bleating in the marshes at nightfall in early spring; or take him to a "queer nest" in the bank by a wood-road where, cunningly woven, with its canopy of dry leaves, is the nest of the oven bird.

One day a boy brought him a dead bird he had picked up on the railroad track, which, though like a sparrow, was different from any sparrow he had seen-mottled grey and brown, its round wings edged with yellow, bits of yellow on its shoulders, and a yellowish line over the eyes. Mr. Burroughs said it looked as though it had rubbed against a dandelion, and some of the colour had "crocked off." It is one of the birds to be searched for, and will tax a boy's powers of observation not a little. It suggests a miniature meadow lark with its long and strong legs and feet. If any boy finds whether this bird walks or hops, John o' Birds will be glad to know, as he has not yet positively found out himself. Its song is fine like that of a grasshopper, a peculiar buzzing sound. It is called the grasshopper sparrow. Other rare "finds" in Sparrowdom are the swamp sparrow and the Henslow sparrow.

In the years when, working for Uncle Sam, Mr. Burroughs went back to his father's farm for his vacations, he had a chum, Channy, a dearly loved nephew, who rambled with him in the old Bark-peeling and up on Old Clump. Channy was the youth who, in the hemlocks helped him get the material which went into the essay by that name; the youth so often mentioned in his books who followed the streams casting for trout; who once caught a swarm of bees in his hat; who, on seeing frogspawn in the creek thought it good enough to eat; the 
one who found a certain chickadee's nest on Old Clump when even John o' Birds would have given it up; the one who helped him discover the rare nest of the mourning ground-warbler, which, until then, had not been described. (After the young had flown, they sent the nest to the Smithsonian Institute, and in his description of it, $\mathrm{Mr}$. Burroughs gave Channy credit for its discovery.)

One April day when Uncle John and Channy were driving along a country road, a slim, ashen-grey bird with white markings, smaller than a robin, flew heavily from a nearby fence to a tree, a smaller bird in its beak. It was a shrike. Channy, who saw him thrust his victim into a fork of the tree, and wipe his bloody beak on the bark, was almost beside himself with rage. Jumping from the wagon, and pulling off his mitten, he seized a stone and let drive. The shrike escaped by a hair's breadth, the stone grazing the branch where he sat. The butcher bird had brained his little victim.

To one with a keen interest in every phase of Nature, all is fish that comes to net or hook. Once in a trout stream, when Mr. Burroughs was dismayed at losing a specially fine trout, he found, on disentangling his hook from the overhead branches, that he had caught something finer still-a humming bird's tiny nest firmly saddled there and looking at first like a mere wart on the limb.

I remember the first time Mr. Burroughs came to visit me. A roamer in the woods, knowing he was there, brought to my door several trophies, among them the exquisite cup-shaped nest of the wood pewee with its coating of grey-green lichens, and the grey hanging nest of the oriole. No sooner had my guest taken the two nests in his hands than he said, "Why, here are three 


\section{JOHN BURROUGHS-BOY AND MAN}

nests instead of two!" and, poking in the oriole's nest, showed us some loosely-woven brown twigs, arranged criss-cross. "A $\log$ cabin in a palace," he addedthrifty Jenny Wren had appropriated the oriole's elegant gourd-like structure.

Though having gone a-birding for so many years, John o' Birds never loses interest in nests of a kind often found before; but is pretty sure each season to add new ones to his store. One recent "find" was the nest of the blackbilled cuckoo, found in the red thorns near Woodchuck Lodge - the most forbidding nest imaginable! "A crown of thorns made into a cradle," he would say on showing it to callers. Woven loosely of the dried thorn twigs, the sharp spines left in place, it rested on a limb in the dense, threatening tree-a savage-looking nest, yet with a soft, shredded lining of some reddish-brown material of which our Bird Lover would like much to find the source.

Mr. Burroughs shows scant mercy for the "bird highwaymen" or "human weasels," as he calls men or boys who commit atrocities on the birds, and in the name of science! If one is bent on making a collection, he says, let him content himself with one or two eggs of a kind; but, so far as he is concerned, he says that to look at the birds' eggs and leave them in the nest is the best advice he can give a collector. To see the birds building; to watch for the fragile eggs; to safeguard, if one can, them and the young; to watch the nestlings grow; to be present, if possible, when the tiny crafts are launched in the airthis, after all, is the best way to go bird-nesting.

As his readers know, many of the Fruit Farmer's days off were spent in wild honey quests. Here is one he made in his eighty-third year: It was a clear, warm September 


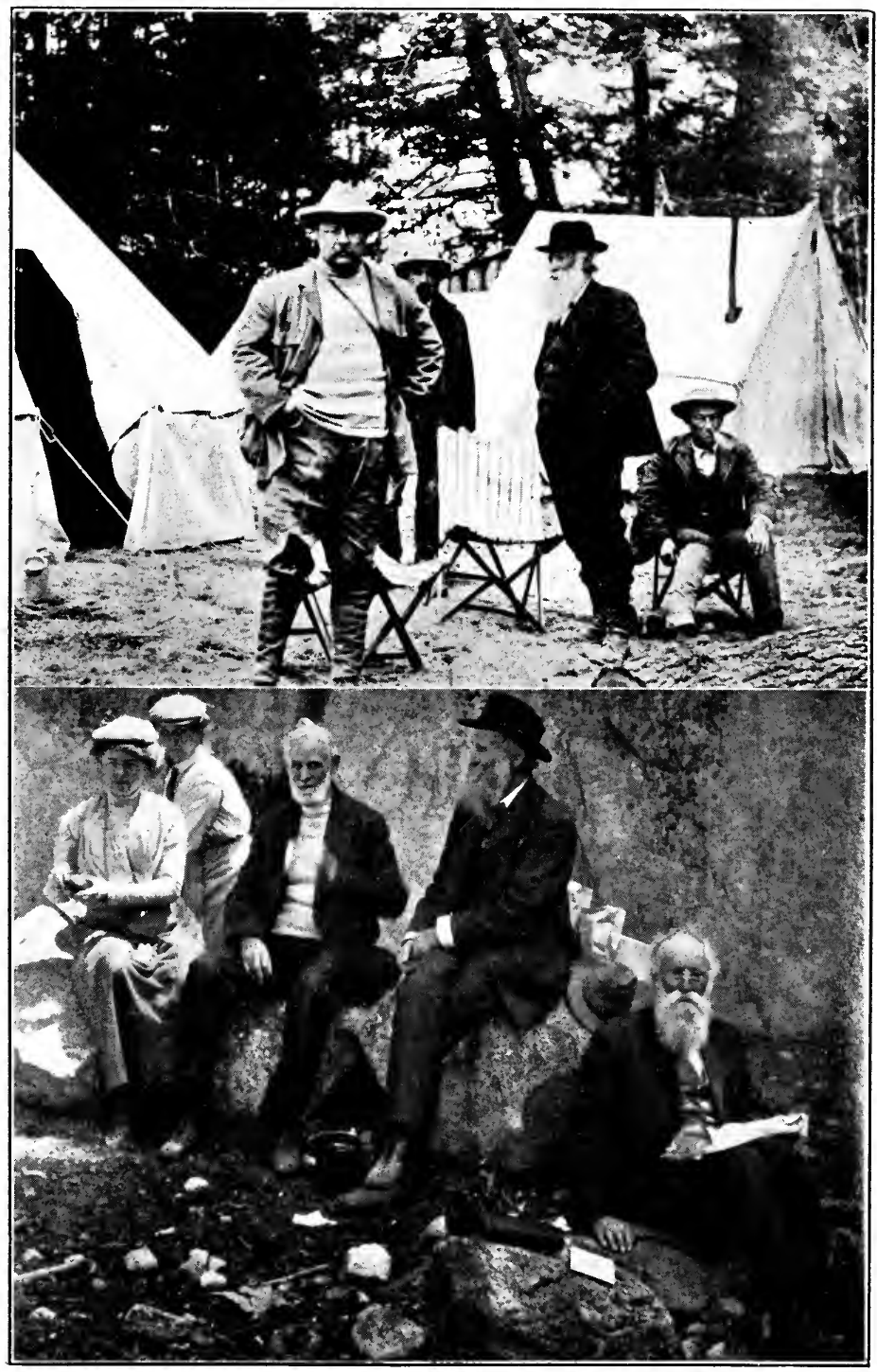

Photos by F. P. Clatworthy

John Burroughs with Theodore Roosevelt in the Yellowstone

In Yosemite with John Muir 


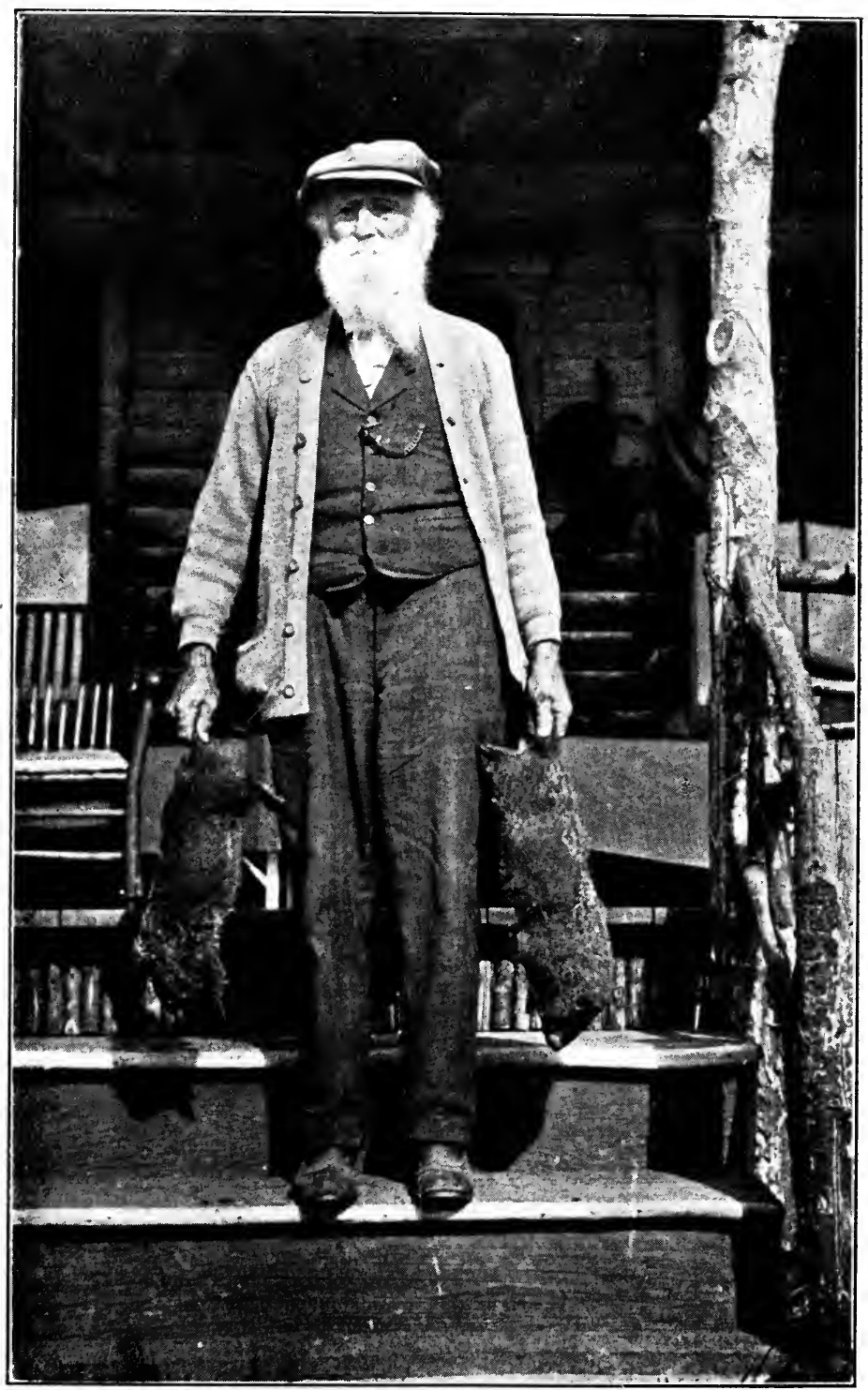

Photo by Albert Houghton Prus:

The Laird of Woodchuck Lodge 
afternoon when five of us, with Socrates, the hound, started to hunt a bee-tree in the woods high above Woodchuck Lodge-Uncle John, John C., an adult nephew, Howard, a youth of twenty, Ivan, a boy of seven, and the writer.

It had been about thirty years since the veteran Bee Hunter had trailed the little free-booters to their hidden hoards on "Mt. Hymettus" in the Slabsides country, and now, as in his boyhood, he was to seek a bee-tree on his native heath.

Armed with a small tin pail, and a bottle containing sweetened vinegar, John C. leads the way. We clamber over a stone wall, and climbing a stony pasture, reach an open sunny clearing in the woods. Here, finding a bee at work on some asters, John C. sweeps it into his pail, which already contains a cluster of aster blooms besmeared with the sweetened lure. Quickly covering the pail, he sets it on a boulder, and after giving the captive time to gorge himself, removes the lid.

We sit on the ground so as to bring the pail against the sky as a background, and watch sharply. When the bee emerges from the pail it rises slowly and heavily; it circles around, till, getting its bearings, starts across the brush heap, past some basswood stumps, and enters the woods about seventy yards away.

In less than five minutes the asters in the pail, and others upon the rock, are alive with bees. The news has travelled fast. The bees hum angrily about, as though scenting foul play as well as honey. And it is a betrayal of the little workers who are, in the main, honest citizens; for it is only in the fall when their legitimate sources of supply are beginning to fail that they can be tempted to 


\section{JOHN BURROUGHS-BOY AND MAN}

steal our stores. And we, the tempters, following them with the booty, turn about and steal theirs!

What guileless thieves they are! If they suspected our Sherlock Holmes methods, they might baffle us by taking a circuitous route, but no! settling on the asters and gorging themselves, when they get all they can carry, they go straight home. How quickly their fellows smell out the secret! Our asters are soon alive with bees. Now, no longer pausing for that spiral flight, they go directly back and forth, taking the fastest Bee Express on the line.

In less than twenty minutes our line is well established, and, judging by the short time it takes the bees to come and go, the tree is not far in the woods.

Following the line into the woods, Uncle John and John C. enter, scanning the trees closely, searching for sight and sound of the bees; while Howard, Ivan, and I move about five hundred yards to the right, "down in Jesse's Chopping," and there set up another lure on a stump, to cross-line them. Shortly after we remove the lid, other bees approach and nose around the asters, then rise and fly back toward the woods. Soon our flowers are covered with a brown and buzzing mass. A few minutes more and the cross-line is established. This line makes a sharp angle with the old one, and shows us, as already suspected, that the bee-tree is not far in the woods.

Going to the point where the lines cross we seek the tree. While all are moving about, scanning the likely trees, Howard, shouting, "There they are!" points to the top of a tall sycamore where we see the bees going in and out of a small hole. Our quest is ended. The bee hunters carve their initials and date on the tree, to hold the claim. The 
next day we go armed for the fray with axe and saw, a large tin pail, a case knife, and a long-handled spoon. On arriving at the tree, the men bind tightly their trousers at the ankles, and their coat sleeves at the wrists, put large squares of mosquito netting over head and neck, clap down hats, turn up collars, put on gloves, and set about to fell the tree.

As it crashes to the ground, we, the uninitiated, less well protected, run away, but are soon edging near. The bees show no signs of molesting us. They are too busy seizing as much honey as they can hold. Howard screws his courage up and boldly hacks the fallen trunk near the hole, exposing a long card of amber-coloured comb alive with a buzzing angry mass. Driving the bees away as well as he can, and loosening the comb, he lifts it out, the bees fiercely contesting the prize with him. They find the weak spots around his wrists, they buzz about his ears, they sting through his gloves; but, though dancing about in pain, he persists heroically.

"Are you stung, Howard?" cries the Bee Hunter from a safe distance. "Rub some of the honey on your wrist, it will stop the hurt."

"I'll have to find some first," said Howard, ruefully examining the comb, which, on coming near, we saw was dry and brown and holding scarcely a vestige of the sweet we sought.

"It must be further down in the tree," said John C. "You will have to lay open more of it. There's surely some good comb below."

Again the youth set to work, but with a like result. What little more he found was empty-the damp, cold season had been a hard one for bees; they had evidently 


\section{JOHN BURROUGHS-BOY AND MAN}

eaten all their own store-no wonder they were so eager for our sweetened asters!

We looked upon the disconsolate, bewildered bees with pity and were sorry at the ruin we had wrought, still they could not have lived much longer on their scanty store. Carrying our empty pails and our implements of war, we marched down the hill, a little crest-fallen at so sorry a termination of our honey quest; but the veteran Bee Hunter reminded us that "the sweet is not alone in the honey, but in the pursuit over the hills and through the woods these charming days."

Once in a summer long ago the Fruit Farmer took several days off and made his Pepacton voyage, of which he has written so engagingly in his book by that name. He would do what no white man had done, descend that branch of the Delaware in a boat. The lumbermen shot rafts of pine and hemlock down on the spring and fall freshets, and Indians had doubtless made the trip in canoes, but he wanted to paddle his own canoe adown that winding stream; only his was not a trim birch bark affair, but a flat-bottomed scow of pine. He had made it himself at Riverby, a simple affair, twelve feet long, the sides of three-quarter inch stuff, the bottom of light, halfinch stuff. It took him about a week, and after her brown coat of paint, she was ready for the plunge.

With boat, and old blue army blankets, rubber coat and boots, fishing-tackle and revolver, cooking utensils and provisions, going by rail to Arkville, this modern Noah embarked on his voyage. He had tried, but in vain, to get Myron Benton to snub his farm and join him; so having no boy chum, not even a dog, he set out alone, launching his boat in Dry Brook one sunny August day. In 
dragging his boat over an elm which disputed his progress, he found the water of Dry Brook wet enough for all practical purposes; and also found on reaching the Pepacton, where he had hoped for clearer sailing, that he had to "keep his eye peeled" continually.

He made only eight miles that first day, and ardour and clothing were considerably dampened. The little river, narrow and shallow as it was, seemed to shut him off from his kind, and the milk of human kindness on the shore (judging from the cow's milk he had bought at a farm house) was not to his liking. The monotonous voice of the stream, and the crouching rocks along the shore, got on his nerves; his rubber boots were like clods of lead-he was a miserable, forlorn voyager.

But on taking to the woods and spreading his blanket under the friendly birches, he made a quick trip to Dreamland; and in the morning a more genial look shone on Mother Nature's face, and a more buoyant feeling cheered the voyager's heart.

The encounter he most enjoyed was with two boys of ten and twelve racing on rafts, who left their floats and rode a way ${ }^{\prime}$ with him. Examining his craft critically, they asked pointed questions as to her history and destination; praised his steermanship; praised his rod and his trappings, even his despised rubber boots; they were, in fact, a godsend to the lone man, and when they left him, just below Bark-a-boom, he was bereft indeed.

Two other boys, encountered two days later, were just as welcome, although they did tell him fearful tales of the whirlpools and eddies and binocles down below. After their solemn warnings he told them he had better go ashore and post some letters to his friends before risking 


\section{JOHN BURROUGHS-BOY AND MAN}

all that, so they proudly marched him up the street, calling patronizingly to the fellows they met, a few explanations as to the stranger they had in tow:

"Come from the head of the river-made his own boat -may go way to where the river goes into the sea-doing it just for fun"-and the procession marched on, gathering reinforcements along the way.

Once when wrapped in rubber coat and crouching under a rock for shelter, having protected his provisions as best he could with his blanket, a catbird mockingly called: "There! there! What did I tell you? Pretty pickle, pretty pickle to be in!" But he had been in worse pickles and managed to get from one to another, and out again, and to snap his fingers at the saucy catbird.

A wild duck and her brood challenged him to a race, kicking the water into foam as they sped before him, their pink feet looking like swiftly revolving wheels. So astonished was he, when they actually outdistanced him, that he dropped his paddle and cheered them heartily.

The voyage ended at 'Hancock, after fifty miles of mishap, fun, and adventure.

There is nothing that J. B., as he calls himself, likes better than camping out. $\mathrm{He}$ is an incurable camper, and prides himself on his camper's skill, as well he may. Many of his days off have been thus spent in the wilds. But he learned his wood-craft by degrees, and Experience was a sterner teacher than a friendly Scout Master is. $\mathrm{He}$ was twenty-three years old when he made his first camping-trip, accompanied by young Allen, of whom we have learned. Equipped with what they supposed was the 
proper outfit, they set out to trace the Beaverkill to its source and fish for trout on Balsam Lake.

They took along a gun, an axe, their hammocks made of two blankets tied with ropes, fishing-tackle, a knapsack with a lot of books, some bread, salt pork, sugar, and coffee.

Dressed in rough togs, they started off early in July, Farmer Burroughs driving them to the mouth of Mill Brook, a famous trout stream. From there a man with a buckboard carried them over the mountain into the Beaverkill, setting them down at nightfall in the primitive forest, no sign of civilization near. As the sound of his wagon died away, they felt as solemn as owls, and twice as lonely.

Through the night they took turns in keeping up the fire, J. B. taking the first watch. Sitting there and peering into the darkness, he felt creepy enough, and fired shots in several directions lest the creatures which seemed to be lurking out there in the darkness should close in on them. He confesses that he was afraid:

I was actually scared all night long. I sat with gun close at hand. You see I had never camped out before, and the woods at night, and strange woods, at that, are far different than by day. We were apparently in the depths of a primitive forest, and the stillness and blackness were awful!

As the fire died down, I could see an army of foes beleaguering us. I seemed to have reverted to my childhood fears of night and the dark, or, more likely, to the fear of the childhood of the race, when primitive man knew he had to guard against his ambushed foes.

When it came Allen's turn to watch, I was afraid to sleep for fear he would let the fire go down, so slept with one eye open, if I slept at all. In the morning, when we saw smoke from a chimney not far away, how absurd our fears seemed!

The next day, shouldering our duds we started up the Beaverkill and encamped on Balsam Lake. We strung up our blankets, but how we 
suffered from the cold, until, in the night, when our stakes slipped, or a rope broke, and we fell to the ground! There we lay huddled together, hoping to get some warmth from each other, but soon found, to our surprise, that we were not nearly so cold on the ground-Mother Nature's blanket under ours was a great addition.

The next day we tried to fish for trout, but were such greenhorns we didn't know how to manage our flies, till some men who came along showed us how, and then we took a lot.

As we followed the dim trail back to the head of Mill Brook in the rain, encumbered by the books we had not looked into, we halted, and tried to cook some trout and make coffee. But it was a sorry failure; and when we came to a rude little log cabin in a clearing, domesticity had never looked so good to us before.

In the morning we hired our host, Close by name, to take us across the mountain. He had no wagon, but Allen and I rode his horses, and he trudged along beside us in the rain. It must have been at least eight miles from there to Margaretville. When we asked him what our bill was (for lodging, food, the use of his horses and his day's trampand he had to tramp all the way back!), he said he guessed he would have to charge us a dollar! and that man's name was Close!

In the years that followed there were many other camping-trips, of which he has written in detail. There was the one to Thomas's Lake (now Beecher Lake) on which eventful march, following the vague direction to bear well to the left, they got lost, and found, and lost again, times innumerable; where, at last, finding the elusive lake, and taking trout for supper, the exhausted and famished cook (J. B.) capsized the trout in the ashes just as he was about to serve them. It was on that trip that on coming out of the woods, after long wanderings, and thinking themselves in a far distant region, they found they had come out a few yards from where they had gone in just forty-eight hours before!

There was the camping-trip on the Neversink when Uncle John and Channy and four others had some delectable, and some quite other, experiences; where the midges 
made Aaron, the old soldier, indulge in most inflammatory remarks; where visits from a porcupine, and other sleepchasing events, transpired; where they beheld a wondrous aurora borealis; and where the exceptional fine trouting all made up an experience fraught with fragrant memories, barring one night in an odoriferous stable-shelter on the rain-swollen Neversink.

There was the attack on Peekamose with their march through the wild and desolate region of the Rondout; their ideal camping-sites; their debauches of poetry and coffee; and their never-to-be-forgotten camp-fire talks.

There was the brief camping-venture when the wives went along, too; the venture which started out so merrily, by Furlow Lake, a trout lake high in the Catskills, their only tents the birches and maples, their only beds the hemlock boughs.

Scarcely had the sylvan supper of brown trout on the mossy tables, and wild strawberries on fronds of fern been cleared away, when a low rumbling put a different face upon the scene. The lake grew black as ink. Bombshells were soon bursting overhead; and the torrents fell. Drenched to the skin, the terrified women and their solemn lords hovered over the struggling fire, or cowered in the darkness as though to escape the searching shafts of Jove. Long after midnight, when the bombardment and downpour ceased, waterlogged in body and mind, they threw themselves upon the saturated ground under the dripping trees, in utter misery. With the dawn, the wives lifted their weary voices in unison and begged eloquently for home, sweet home.

When Aaron and J. B. went camping in Canada, while being whirled through New Hampshire and Vermont, J. B. 
seemed to be reviewing the geography of his boyhood. He looked upon the dusky streams with delight, the names of which he had learned in the West Settlement schoolthe Merrimac, the Connecticut, and the Passumpsic, while Lake Memphramagog, which he saw at sunset, was like molten gold.

At their first glimpse of the St. Lawrence Aaron cried, "Iliad of rivers! Your Hudson must take a back seat now!" and, indeed, its sublimities were Homeric from beginning to end. Other schoolboy lessons came to mind as the West Settlement pupil looked up the steep vertical sides of the Plains of Abraham where Wolfe and his army had clambered and stood in the enemy's rear, long, long ago.

For the camping experience to Lake St. John, for the account of the monstrous trout Aaron caught, and J. B. helped to land; for the scales Joe, the guide, improvised, by balancing a strip of board and using their provisions as weights; for the sail down the Saguenay, and the stupendous scenery of Cape Trinity and Cape Eternity, one must read our camper's account in "The Halcyon in Canada."

When in $1876 \mathrm{~J}$. B. took some days off and got his "Taste of Maine Birch," the best part of the whole experience was Uncle Nathan, the guide, a hunter and trapper for forty years. An Indian had taught him to make birchbark canoes, and he made the one they used on the trip. What wood-craft it showed; what a wild free time it promised!

To Uncle Nathan the birch tree was the god of his idolatry. Nearly his entire equipment came from it-canoe, tent, waterproof, buckets, plates, cups, spoons, torches, 
kindling, fuel. The birch tree was his china closet and linen closet-when the birch bark table-cloth was soiled, he used it for torches, drawing his fresh supply from the ever-ready store-room.

From their camp on Pleasant Pond the loons appeared to laugh to scorn their impotent shotguns, but J. B., who had a breech-loading rifle, decided, if possible, to "put one over" on those scornful loons. So as two came swimming within rifle range, letting forth a volley of laughter as they came, he cracked his rifle. Both loons seemed to dive, but only one escaped; the other that floated on the water had laughed his last. J. B. stuffed the handsome bird, which ever since has graced a corner in the stately hall at Riverby, a mute reminder of that camp in the Maine wilds.

On that jaunt, in a lumberman's hay barn on Moxie Lake, the campers sought shelter from rain and were lulled to sleep by Uncle Nathan's yarns. Like John Muir, Uncle Nathan would talk on engagingly if uninterrupted, but was as shy of questions as a fox is of a trap. J. B. says he talked in a circle, just as he hunted moose and caribou, careful lest one scent his opinions, though ever willing to tell what he had seen. 


\section{CHAPTER XVII}

WORK AND PLAY IN LATER YEARS

(1899-1920)

Two essays especially interesting to young readers were written by Mr. Burroughs at Slabsides in 1899-"The Art of Seeing Things," in Leaf and Tendril, and "Wild Life about my Cabin," in Far and Near. That spring, when happyin his woodland cabin, poking about thewoods, burning brush, rowing on the Shattega, and nibbling betimes at his pen, there came a disturbing proposition -an invitation to go on the Harriman Alaskan Expedition. With all his curiosity about new lands, he shrank from such a departure from his quiet life, but after debating the question, finally turned the key in the door of Slabsides, journeyed across the States, and, on the last day of May took ship at Seattle for Alaska.

Mr. E. H. Harriman and family were joined on this expedition by about forty well-known scientists and artists-botanists, geologists, zoologists, ornithologists, and so on. There was John Muir, the Great Ice Chief, Dr. Fernow, the Tree Chief, Dr. Grinnell, the expert on Indians, Louis Agassiz Fuertes, the bird portrait painter, and many others eminent in various fields. Mr. Muir knew so much about glaciers, and so considered them his special property, that he hardly allowed anyone else an opinion concerning them. Perhaps of all the thrilling experiences on that expedition of so many thrills, the chief was that 
early encounter with the glacier named after their fellowvoyager. Approaching its front to within two miles of its crumbling wall of ice, which towered two hundred and fifty feet above them, they dropped anchor near the little cabin where the Great Ice Chief had dwelt some years before when he discovered the glacier. They heard the deafening explosions as enormous masses separated, were submerged, then slowly rose like monsters of the deep, their blue forms gradually emerging from snowy clouds of foam. One day while near the Muir, a half mile of the front detached itself, arising again in floating bergs as blue as sapphires.

They visited greater glaciers later, the greatest of which was the Malaspina, one hundred and fifty square miles in extent, with a fifty-mile front on the sea, and running back thirty miles or more to the Saint Elias Range.

At Port Wells, the extreme northeast arm of Prince Williams Sound, they entered another great ice-chest of glaciers. There were, he said:

Glaciers to right of them, Glaciers to left of them, Glaciers in front of them, which Volleyed and thundered.

To many of these they gave names-Harvard, Yale, Columbia, Amherst, Radcliffe, Smith, Bryn Mawr, Vassar, and Wellesley.

While exploring in the vicinity of the Barry glacier, where a ship had never gone before, they encountered a mighty obstacle effectually barring their way, later named the Harriman glacier. It was while there that their vessel was caught in a strong ebbing tide, and, hesitating to respond to the helm, seemed for a brief period to be making 
directly for the lofty wall of ice on their port side; but happily the ship soon came about, and on they sailed merrily.

The Seal Islands, the paradise of Kadiak, the Kadiak bear and cub which Mr. Harriman shot, the woods upholstered ankle-deep with moss, the winsome flowers, these and much else are engagingly described in Far and Near. In the New York Zoological Park and also in the Peabody Museum at Harvard University are totem poles which they brought back from that expedition.

Of course the bird life in Alaska especially interested Mr. Burroughs. Will he ever forget the humming bird he saw on the Muir glacier, carried by its tiny wings three thousand miles or more? Some birds there were which set him to rhyming - the Oregon robin, the golden crowned sparrow, and the Lapland longspur, the last-named reminding him strongly of his boyhood bobolink:

On Unalaska's emerald lea, On lonely isles in Bering Sea, On far Siberia's barren shore, On North Alaska's tundra floor, At morn, at noon, in pallid night

We heard thy song, and saw thy flight, While I, sighing, could but think Of my boyhood's bobolink.

He never tired of watching the albatrosses which followed their ship in effortless flight, or the Arctic terns, as with sickle-like wings they reapt the air. There they saw the little water ouzel, and the golden plover with its soft and plaintive call. The familiar barn swallows in that land without barns, seemed at ease; song sparrows, though nearly as large as catbirds, were much like those of the Catskills. 
In Bering Sea, while making its perilous way toward Siberia through night and fog, the George W. Elder suddenly grated on the rocks. She trembled from stern to stern. Terrified, all on board sprang to their feet in mute alarm; but the engines were quickly reversed, a sail was hoisted, the ship's prow soon swung to the right, and they were again afloat.

In speaking of this trip Mr. Burroughs often says that he travelled two hours in Asia, and was tempted to write a book about it, but thought better of it. When we read what he did write of that first glimpse of Asia, "crushed down there on the rim of the world, as though with the weight of her centuries, and her cruel Czar's iniquities," we wish he had not checked his impulse.

Of all the live stock that went aboard the ship at Seattle -steers, sheep, chickens, turkeys, and horses-nothing remained at the end of the voyage but one dependable cow which had gone with them to Siberia and back, and given milk all the way.

Since $1900 \mathrm{Mr}$. Burroughs has led a more varied and eventful life than theretofore. His son had entered Harvard two years previously, which in itself took him frequently to Boston, and, the "habit of gadding" once established, frequent jaunts became customary. $\mathrm{He}$ entered eagerly into the college life, going with Julian to football and baseball games and rowing contests.

During the hours he spent in the library at Harvard while editing his Songs of Nature, he became inoculated with the germs of the rhyming fever, and made many rhymes himself, the most of which he gathered later into Bird and Bough. 


\section{JOHN BURROUGHS-BOY AND MAN}

The fall of 1901 was a memorable one to the writer, in that she then made the pilgrimage to Slabsides which resulted in her friendship and long association with John o' Birds. Mr. Burroughs, then working on the Life of Audubon, for the Beacon Biography series, was finding the work, not self-elected, irksome indeed. It dragged. Finishing touches on Literary Values were also occupying him. He wanted much to strike work and run away to Jamaica with a friend and his son. At length he did run away, entrusting the writer with some of the mechanical work on those volumes, and with seeing the Audubon through the press. Hence it has come about that of the last twelve volumes which have come from his pen (and of three more nearly ready to see the light), the writer has had the privilege of cooperating with the author, relieving him, by typing, proof-reading, and attention to some of the drudgery connected with bookmaking. Twelve books from the age of thirty to sixtyfour, and fifteen since he has passed the four-and-sixtieth milestone! Dr. Osler's much-quoted dictum as to the comparative uselessness of a man after forty is hardly applicable to Oom John!

Mr. Burroughs has said that when (in February 1902) he went to Jamaica, he lost February and found August. And in his "Lost February," his reader finds that he has, on the whole, little admiration for that land of perpetual summer. In fact, we sometimes find him railing against the barbaric Nature encountered there-Nature without the lure of spring, the repose of autumn, or the sternness of winter! Nature with her spikes and spines, her stings and stabs, her rustling and tattered foliage varnished by sun and tropic heat, her fleas and her sand-ants and 


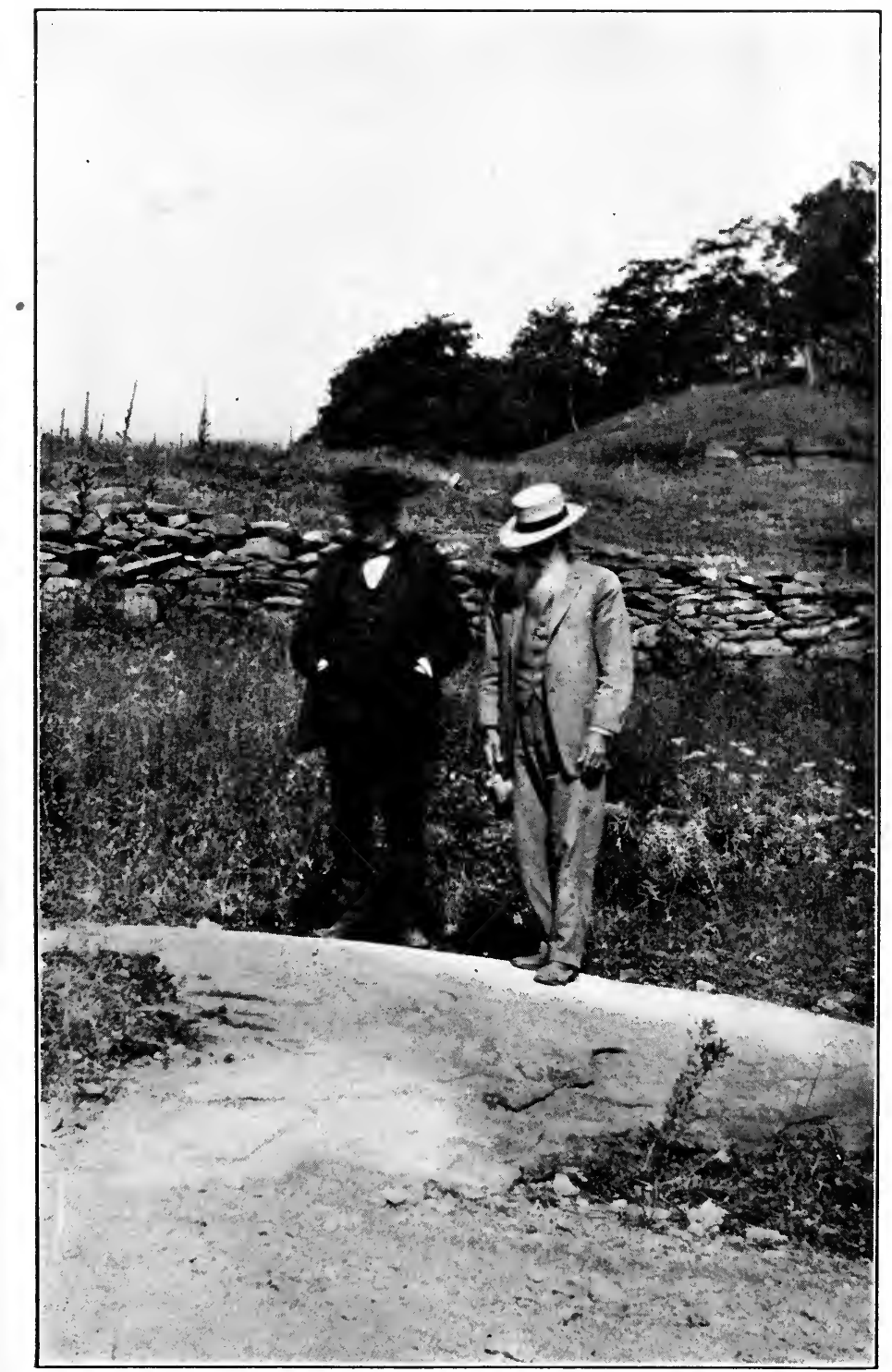

John Burroughs showing Edison glacier marks on the home farm 


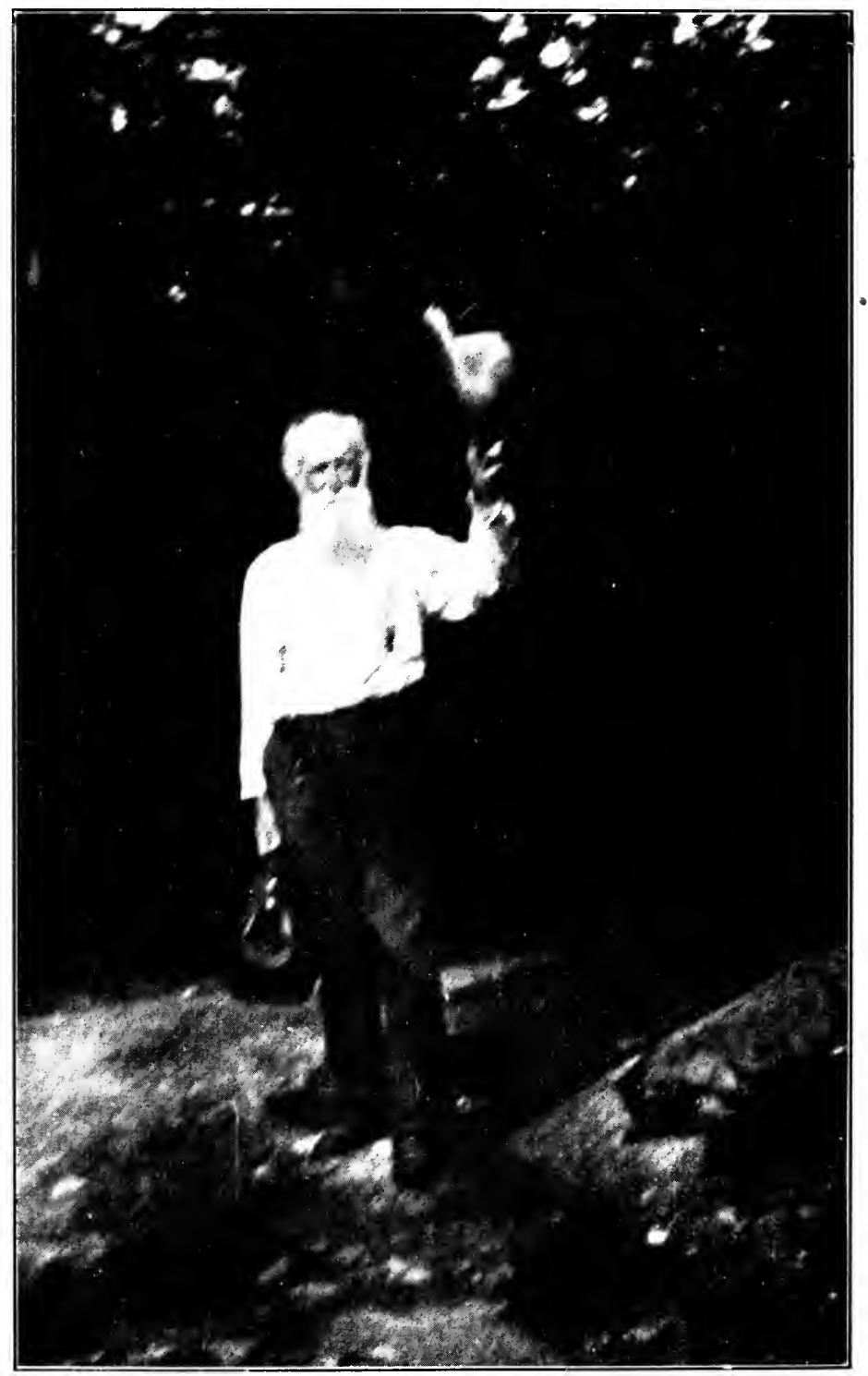

Good-bye!

Photo by Olive Hinman 
mosquitoes, her lairs and her jungles-brilliant, barbaric Princess-too ready with her fangs, too chary of tenderness and charm.

And yet we find him saying a good word for the Blue Mountains, the limpid streams, the morning-glory colours of the Caribbean, the soft, luminous nights with the Southern Cross hanging low on the horizon; and above all for the shy solitaire, or "shine eye"-a bird seldom seen but often heard, whose melodious and plaintive strain - "a series of tinkling, bell-like notes," with an appealing, flute-like ending - entirely won his heart.

And barbaric Nature treated him to many a novelty he would not have missed-the flying-fish with their mechanical flight, the curious behaviour of the "shame lady," or sensitive plant, the clownish-looking tody in suit of green and massive yellow beak, the mongoose, the queer-looking East Indian oxen, the nearly black humming bird with the two long plumes in its tail, the lubberly pelicans diving for fish, the giant fireflies, so large the travellers thought their lights to be those of the elusive town they were seeking, and then that strange Cock Pit Country with the rough-hewn rocky bowls hundreds of feet deep and a thousand or more feet across. Nevertheless, on his return to familiar scenes, the robins he heard carolling in the treetops at sundown pleased him better than anything seen or heard in Jamaica.

During the spring of 1902 our author had keen delight in helping his son get out stone for the foundations of his cottage built at Riverby, a few yards to the left of the Bark Study. Then the excitement of discussing the building plans, and the pleasure of watching the house grow, and the joy in the fall when the young couple moved in and set 
up house-keeping in Love-cote, as the cottage was at first named*

After the Jamaican trip, some winters or parts of winters have been spent in Bermuda, in Washington, North Carolina, Georgia, and Florida, some on the Pacific Coast, some yachting around Cuba, in the Sialia (The Blue Bird) with Mr. Henry Ford, while some have also been cosily spent in The Nest at Riverby, or in the luxurious simplicity of Yama Farms Inn, in the Shawangunk Mountains.

In 1903 , our veteran literary naturalist became disturbed over the growing tendency of certain writers to misrepresent Nature-romancing about her when purporting to give straight natural history. With fiction undisguised as fiction, he had no quarrel, but for fiction disguised as natural history he had the utmost scorn, so he put on the gloves, entered the arena, and delivered knockout blows to the traducers of his mistress. The first bout was in an essay in the March Atlantic, in 1903, "Real and Sham Natural History." Many another followed for a year or two, the records of which are mostly to be found in his volume called Ways of Nature. It was all a contention for clear seeing and honest reporting-in other words, a demand for a square deal with Nature.

Seeing a scrap on between Oom John and those whom he dubbed Nature Fakers, the valiant Roosevelt soon came bounding in the ring, striking out right and left with the Big Stick, belabouring the offenders unmercifully, almost skinning them alive! Their joint efforts laid many an offender low, and many another, convinced

* In 1914, when his son moved away, the cottage, rechristened The Nest, became the home of the writer, with whom Mr. and Mrs. Burroughs came to live. 
that, after all, honesty is the best policy, straightway reformed. In time the belligerents cooled off and shook hands, and nature faking became as a tale that is told.

Back in his ranch days Theodore Roosevelt had written ardent letters of appreciation to Mr. Burroughs about his books, and they had met on various occasions-when Roosevelt was Civil Service Commissioner, when he was Governor, when Ted had been to Slabsides for a day or two, and Ted's father had wanted to go but had been too busy setting right certain places in the political world that were out of joint. But it was not until 1903 that the intimate friendship between these two men, so opposite in type, age, character and training, began. They had one passion in common-love of Nature, though courting the Dame in such diverse ways.

In the spring of 1903, when that Big Boy who was playing the game of being President, and playing it for all he was worth, began to pant for the wilds, he decided to take a vacation, Congress or no Congress, in Yellowstone Park, and asked John Burroughs to take it with him. The yellow newspapers, getting wind of the trip, made much of it, calling it a hunting trip, assuming that the President was going into the Park to kill the elk and moose and caribou. Some of the correspondents of Mr. Burroughs hoped he would rebuke the President by refusing to go with him. A Vermont woman wrote urging him to restrain the Hunter as much as possible, and teach him to love the animals as he did. "She little knew," confessed Mr. Burroughs, "that I myself was cherishing the hope that I might shoot a cougar or a bob cat. But as a matter of fact, the President did not go there to hunt. He did not once fire a gun in the Park." 
In each city along the route there was a round of handshaking, dining, and speech-making for the Strenuous One who, though declaring it needed the strength of a bull moose to stand it, seemed to thrive on it, keeping fit as a fiddle all through.

The boy in the President came out continually on this trip, and the elder boy concluded that was why they "took" to each other so readily. Roosevelt's unfeigned delight at the hearty demonstrations along the way was refreshing. And when in St. Paul, as their carriage was slowly creeping along in the crowds, they spied a band of schoolgirls carrying a banner-" The John Burroughs Club"-and a blushing maiden pushed her way to the President's carriage and timidly thrust a bouquet on the lap of Mr. Burroughs, the President was greatly tickled.

On this trip Roosevelt gave the name of Oom John to our friend. Saying that he felt like a hen with one chicken, he lived up to this feeling and scratched around and hovered over his lone charge with kindly care. As for Oom John, being a Slabsider, and not having hobnobbed with presidents before, he was at a loss how to address his host. Should he call him Your Excellency, which they say Washington exacted, or Mr. President, or what? As His Excellency was much averse to that epithet, they compromised on His Transparency -as having at least the merit of accuracy!

One day at luncheon, while passing a little settlement in Dakota, they saw a teacher and her pupils watching eagerly as the train passed. Jumping up, with napkin in hand, the President rushed to the platform and waved to them. "Those children wanted to see the President of 


\section{WORK AND PLAY IN LATER YEARS 333}

the United States," said he, "and I couldn't disappoint them-they may never have another chance."

T. R. bubbled with joy when the former foreman of his Elkhorn Ranch, a cowboy friend, boarded the train and rode with him a way\$. He bombarded them with questions, recalled events and people they had long since forgotten, remembering even the names of their dogs and horses. At twilight, as the train entered the Bad Lands of North Dakota, he stood on the rear platform and gazed wistfully on the scene. The Bad Lands, over which he had tramped in all seasons, evidently looked very good to the one-time Rancher.

When they entered Yellowstone Park a fine saddle horse was waiting for the President, but an ambulance drawn by mules for Oom John. Somewhat chagrined at being met by such a vehicle, he nevertheless stepped inside as though accustomed to ambulances. With an escort of officers, soldiers, and cowboys, the President, tickled at leaving reporters and politicians behind, started gaily off, the ambulance following. And it immediately followed at such a lively pace, swaying from side to side, that Oom John, grabbing the seat with both hands, said to himself, "This is a Wild West send-off in dead earnest." Faster and wilder grew the ride. Tossed about, he rubbed his bruises with one hand, and clung to the seat with the other. Presently, looking out, he saw the cowboys scrambling up a bank, and the President on his fine stallion, scrambling up there, too, and looking back fiercely as the ambulance thundered by.

"This is certainly the ride of my life," thought Oom John. "I seem to be given the right of way-we have even side-tracked the President!" On they tore for a mile or 
more till, on reaching Fort Yellowstone, he learned that the mules, excited by the presidential cavalcade, had been running away, the driver's only course being to keep them in the road till the hill at that point should give them pause.

The Mammoth Springs in the Park were all that they were "cracked up" to be. The columns of vapour, the sulphurous odours, the unearthly beauty of colour-were all things of which Oom John had never seen the like before. In one of the steaming pools, about an acre in extent, they saw a pair of mallard ducks swimming, the ducks moving to the warmer waters as the party came near. At length, the waters getting too hot for them, they took to their wings, else the travellers might have had boiled mallard for dinner. In a certain pool they caught a trout, and without changing their position, cast the fish into another pool and cooked it.

For Mr. Burroughs the novelty of the geyser region soon wore off. He says that steam and hot water are the same the world over, and he hated to see so much of it going to waste. The Growler, he said, was only a boiling tea kettle on a huge scale. Old Faithful was another, with its lid off, and its contents thrown high in the air. In fact, he cares little for Nature in her spectacular moods. I remember how, in the Hawaiian Islands six years later, he tired of the lurid spectacle of Kilauea long before the rest of the party did.

Eventful was every hour in the Park-whether listening to Townsend's solitaire, or to the singing gophers; catching sight of black-tailed deer, or blue grouse; whether meeting with the Duke of Hell-roaring Creek, or treeing the pigmy owl-a bird not much larger than our bluebird 
-which the President was as happy to get in range of his opera glasses as though he had bagged some bigger game.

One day while making their way down a valley on horseback, T. R., ahead, saw a band of elk a few hundred yards away. Wheeling to the left, he beckoned Oom John to follow, then tore after them. Now Oom John had not been in a saddle since the President was born, but he followed as fast as he could, over rocks and logs and runs. T. R. would now and then look back and beckon impatiently for him to follow faster, as though saying to himself, "If I had a rope around him, he would come faster than that!" At last, his horse puffing, Oom John came up with the President, tarrying at the brow of the hill; and there, scarce fifty yards away, their heads turned toward their pursuers, their tongues hanging out, stood the panting elk, by their whole bearing seeming to beg for mercy. And there sat the President laughing like a boy, delighted at this near view of the noble creatures, and glad to have Oom John see them with him.

Later in the day, from an elevated plateau, they looked down upon fully three thousand elk at one time. In that sightly spot they dismounted and stretched themselves in the sunshine on the flat rocks. The President had his elk, but around Oom John, if the truth must be told, there skurried tiny chipmunks, half the size of those of his native hills, toward which he was drawn far more than to the horde of noble animals they had come so far to see.

One day at Tower Camp, when Billy Hofer, the guide, shouted that a band of mountain sheep were plunging down a sheer wall of trap rock to the creek to drink, all 


\section{JOHN BURROUGHS-BOY AND MAN}

rushed to see the sight. The President, coat off, and towel on neck, had one side of his face shaved and the other lathered when Billy shouted the news.

"By Jove! I must see that," he cried-"the shaving can wait," and T. R. ran with the others to the brink where they saw the sure-footed creatures leaping down the rock, loosening stones as they went, pausing on narrow shelves, then plunging down, down, without accident, to the stream.

Their jolliest times were evenings around the fire when Roosevelt talked of his ranch days, of the world of politics, of books, of his travels, of everything under the sun, moon, and stars. Once in a never-to-be-forgotten talk he took his hearers with him up Kettle Hill, recreating the scene for them. They saw the Leader's face blanch, as he confessed it did, when, on looking across an open basin, he realized that they had to charge up that hill. They saw the storm of bullets, they heard the shout, "We'll have to take that hill!" They saw the lines of the Ninth Cavalry part, as their officer in command, waiting for orders, let Roosevelt and his men charge through, their intrepidity causing the coloured troops to swing into the charge also. And, finally, they saw the crest of the hill swarming with Rough Riders and coloured troopers.

One of the jolliest stories that Oom John remembers is of a Rough Rider who once wrote to the President for help and sympathy from a jail in Arizona: "Dear Colonel," the letter ran, "I am in trouble. I shot a lady in the eye, but, dear Colonel, I did not intend to hit the lady-I was shooting at my wife." And over the tree-tops rang the "dear Colonel's" laughter as he told of it.

The President did not use tobacco in any form, to the 
delight of Oom John, who so loathes tobacco smoke that, while it is enveloping him, he loathes the smoker also.

Although Roosevelt kept his word about killing big game in the Park, there was one wild creature that fell a victim to the hunter's instinct. As they were riding along in a sleigh one day he suddenly jumped out and, with the help of his sombrero, captured and killed a mouse running over the ground. It was a rare variety. He skinned and prepared the pelt and sent it to the National Museum. Oom John crosses his heart and says this is the only game the Great American Hunter killed while in the Park. A week or two later, in Spokane, this incident gave Oom John a sleepless night, for after having told a crowd of people about the capture of that mouse, he got to worrying for fear a malicious reporter, or a stupid typesetter, might change the $u$ to an $o$, so quoting him as saying that the President had killed a moose.

Racing with Roosevelt on skis in the Park was attended with mishaps and ignominious plights for both, until they "got the hang of the pesky things." Once, gaily passing T. R., floundering in the snow, Oom John called out something about the Downfall of the Administration, only to come to grief later and hear T. R. call out, "Who is laughing now, Oom John?"

The correspondence of J. B. and T. R., extending over the years, is of value, not only for its natural history interest, but in its portrayal of character, the President turning easily from affairs of State to tell of the arrival of the white-crowned sparrow on the White House lawn, a purple finch's nest at Sagamore Hill, the identification of the Dominican warbler, or of putting a half-fledged flicker back into its nest-" What a boiling there was when I 


\section{JOHN BURROUGHS-BOY AND MAN}

dropped it in!" Writing of reluctantly shooting the rare warbler, and sending its skin to the American Museum, T. R. said, "The breeding season was past, and no damage came to the species from shooting the specimen, but I must say I care less and less for mere 'collecting' as I grow older."

One day at Sagamore Hill Roosevelt showed Mr. Burroughs a bird journal which he had kept in Egypt, when a lad of fourteen, and a case of African plovers he had set up at that time. That day they examined the skin of a gray timber wolf, and especially its teeth, barely more than an inch long, and had a good laugh at the idea of such teeth reaching the heart of a caribou through the breast with a snap, as a certain nature writer, over his affidavit, had shortly before reported one to have done. Oom John said he doubted if they could reach the heart of a turkey gobbler in that way; and T. R. said one might as well make an affidavit that a Rocky Mountain pack-rat could throw the diamond hitch. As they discussed this and kindred other impossible statements concerning the wild creatures, one can imagine T. R. fairly snapping his teeth while declaring he would like to skin alive the deliberate perpetrator of such lies. Boys don't mince matters, nor always choose their language with extreme nicety, and this boy, who knew what he was talking about, not only delighted in showing up the nature fakers publicly, but in private also let off steam in such expressions as, "What a pestiferous liar that fellow is!"

The last outing T. R. and Oom John ever had together was down at Pine Knot, a secluded place in the woods of Virginia, about a hundred miles from Washington, where they went to name the birds without a gun. 
The night before leaving Washington, at dinner in the White House, one of the guests being an officer in the British army, stationed in India, Oom John was amazed to see the extent of the President's knowledge of Indian affairs, for all the world as though he had been cramming for a Regent Examination on the subject. But the next morning, India, England, and even affairs of the United States were given the cold shoulder, as the bird lovers took an early train for Pine Knot.

The spring migration of warblers being on, Rooseveit was not content to ride the ten miles to the cabin, so both boys jumped from the wagon and began the race of identifying the warblers. The younger boy with his "four eyes," two of which were not first class, kept up with Oom John's sharp eyes, matching a black-poll with a redthroated blue, and a Wilson's black-cap with a pine warbler. After reaching the cabin, they started off on another bird hunt, T. R. walking as if for a wager, through fields and briers and marshes. At last, pausing and mopping their brows, they turned back, having seen few birds.

Mrs. Roosevelt evidently took the Strenuous One to task for rushing their guest about in that fashion, for he came around apologetically later and said, "Oom John, that was not the way to go after the birds-we will do differently tomorrow," and the Saunterer who never makes a dead set at the birds, admitted that he had never gone a-birding just that way before.

On the morrow they named more than seventy-five species of birds, of which Mr. Burroughs knew all but two, and the President all but two, the President having taught J. B. the prairie warbler and Bewick's wren and J. 
B. having taught him the swamp sparrow and one of the rarer warblers. If T. R. had found Lincoln's sparrow, which he usually found there, he would have gone Oom John one better. They loitered in a weedy field a long time, while the President kept his eye peeled for that sparrow, but the sparrow may have been keeping his eye peeled also, for he never came in sight.

One evening at Pine Knot as they sat around the table reading, Mrs. Roosevelt busy with needlework, Roosevelt occupied with Lord Cromer's book on Egypt, and J. B. deep in the horrible account of the man-eating lions of East Africa (the lions carrying their victims into the bushes, and purring as they crunched their bones), suddenly T. R.'s hand came down on the table with such a bang that Mrs. Roosevelt fairly jumped from her chair, and J. B. thought a lion had him sure.

"Why, my dear, what is the matter?" asked Mrs. Roosevelt in a slightly nettled tone.

"I got him!" triumphed the Slayer-he had killed a mosquito, expending enough energy almost to have demolished an African lion.

When on the return trip, his secretary boarded the train, the President was soon deep in the dictation of letters and the consideration of many weighty matters-wrens, warblers, and the sparrow he did not find, side-tracked for the business of the Administration.

When in February, 1909, Mrs. A - and I went to the Pacific Coast in company with Mr. Burroughs, and on to the Hawaiian Islands, we considered ourselves two of the luckiest women in the United States. Mr. Muir was to meet Mr. Burroughs in Arizona, and conduct him 


\section{WORK AND PLAY IN LATER YEARS 341}

through the Petrified Forest region, in and around the Grand Canyon, camp on the Mojave Desert, tarry awhile in Southern California, and pilot him through Yosemite Valley.

As usual, Mr. Burroughs hesitated about going, telling himself he might better court Nature from his own doorstep, but the Call of the West won the day.

My friend and I wondered how Mr. Muir would relish two women tagging along, but were assured by Mr. Burroughs that it would be all right so long as we were good listeners!

That night when we got off the train at Adamana, a voice called out from the obscurity:

"Hello, Johnny, are ye there?"

"Yes, Muir, and with two women in my train."

"Only two, Johnny?" Then to us, "In Alaska there was a whole flock of women hovering around him, tucking him up in rugs, bringing him a bird or a flower to name, putting a stool at his feet, and sitting there in rapt admiration to catch the pearls of wisdom which did not fall from his lips-Oh, two is a very moderate number, I think, Johnny!" And the tall, grizzly, teasing Scot led the way to the little inn. And the next day he led the way across the trackless desert, he and the silent driver in the black sombrero, Mr. Muir talking all the way, the most racy talk I ever heard; talk of lonely wanderings on mountains and glaciers; of his long walk from Wisconsin to the Gulf; of trees and ferns in foreign lands; of his boyhood home in bonny Scotland; talk of storms, earthquakes, avalanches, waterfalls; talk of men and women; of scientists, of poets; of everything under the sun; talk grave and gay, sidesplitting anecdotes one minute, tear-provoking recitals 


\section{JOHN BURROUGHS-BOY AND MAN}

the next. On and on we rode, and on and on he talkedunless, haplessly, some one introduced a question, and then, thrown off the track, the monologist would find difficulty in resuming his theme, and the luckless questioner would be treated to a jibe or a hectoring remark.

Mingling with his racy monologue were the impressions being continually borne in on us of the illimitable, desertlike expanse stretching away on all sides-the gray-green vegetation, an occasional leaping jack rabbit, a band of wild horses flying in the distance, and far, far away the curiously carved pink and lilac and purple mountains.

We lingered for days in those petrified forests where the giant trees, which had swayed in the wind millions of years ago, now lay stretched out for many acres over the sand, or projected from the brilliantly coloured buttes and mesas. Some of them were one hundred and fifty feet long, and five to seven feet in diameter, straight and tapering, no branching as in the trees of to-day. Many were as though sawed into stove lengths. The sand about was strewn with white, glistening chips. We ate luncheon from one of those prostrate trunks whose beautiful wood had been changed to beautiful stone, and from the fissures picked out specimens of jasper, chalcedony, and agate. One of the three forests which we visited had been discovered by Mr. Muir and his daughter Helen while riding over those plains some years before.

The morning we reached the Grand Canyon, Mr. Muir preceded us to the rim, and waving his long arm said, “There! empty your heads of all vanity, and look!" In awed silence we gazed upon the great abyss.

Mr. Muir jeered at us for wanting to make that perilous descent into the Canyon on muleback. "Why need you 
straddle a mule and go down that steep winding icy trail, just to get a few shivers down your backs, when you can see the sublimity and glory here from the top?" Thus he talked, but when, on that mild March day, we did go down Bright Angel trail he, too, straddled a little mule and went down with us, though, save for occasional comments to "Johnny" on the geology of the canyon, his remarks were, for once, few and far between. I think he was only a few degrees less frightened than we were. We ate luncheon four thousand feet below the rim, and looked down another thousand or more upon the Colorado whose hoarse voice we could hear from the Cambrian plateau.

One day while standing at Hopi Point and getting a new and vivid realization of the glory and magnitude of the "Divine Abyss," and of our incalculable privilege, I exclaimed to my friend, "Think of having all this, and John Burroughs and John Muir thrown in!"

"I sometimes wish John Muir was thrown in," retorted J. B., "when he gets between me and the Canyon!"

Mr. Muir told us that when he first saw Yosemite, he and a young man walked most of the way from San Francisco, traversing the great San Joaquin valley, scaling mountains, conquering almost impassable heights and depths, and how when at last they stood and looked down into the chasm, the intrepid youth, who under Muir's guidance had balked at nothing, exclaimed, "Great God! have we got to cross that gulch, too?"

As we drove into the valley from Chinquapin Falls, and first saw mighty El Capitan guarding the entrance, $\mathrm{Mr}$. Muir called out, "How does this compare with the Esopus Valley, Johnny?" But his bantering soon ceased, for in the presence of that beauty and sublimity he became 


\section{JOHN BURROUGHS-BOY AND MAN}

reverently mute. Later he told us that when Emerson was in the Valley, he had said that of all the wonders of the West, Yosemite was the only thing that came up to the brag. The sheer granite walls, over three thousand feet. high, topped by majestic trees, the thundering waterfalls, the level grassy floor, the placid river, which on its way thither had been so turbulent-what a never-to-be-forgotten scene!

While in the Valley Mr. Muir told us of his struggle as a lad to get his education. He lived on fifty cents a week while going through college, and jealously counted the crackers and watched in dismay his candles dwindle. "But," said he, "all that ended when I got in the Valley. I was still poor, but there were things here to fatten my soul." He described his glorious Sunday raids on the heights, tracing waterfalls to their sources, eating and drinking beauty and sublimity, and descending the perilous cliffs by night to be on hand Monday mornings for work in the saw-mill.

While we were there he was much exercised over the question of San Francisco levying on the lesser Yosemite, Hetch Hetchy, for its increased water supply. Though unwilling to give up the fight to keep the utilitarians out, he admitted that the desecration might have to come in time, adding, "The Lord himself couldn't keep the Devil out of the first reservation that ever was made."

When we lamented that we must leave without going to Glacier Rock, Mirror Lake, the Mariposa Grove, and so on, Mr. Muir tauntingly said, "Yes, I pottered around here ten years, and you think you can see it all in four days. You excuse yourselves to God Almighty, who has kept these glories waiting for you, by hurrying away- 
'I've got to get back to Slabsides,' 'We want to go to Honolulu!"”

It was something of a triumph to get Mr. Burroughs to embark on the Pacific for Hawaii-it seemed so far away from home-although when there, he lost his heart to the happy isles, the rainbow sea, the "liquid sunshine," the warm-hearted people. He liked the look of the childish natives with their leis of flowers; liked the courteous Japanese; the charmèd valleys; the weird Hawaiian music; yes, and he liked the sweet-fleshed papayas (melons which grow on trees) and the luscious mangoes. He drew the line, however, at taro and poi-the latter, which he tried at a native luau (feast) tasted, he said, like sour library paste.

One day a teacher in the public schools, thinking to impress upon her pupils what Mr. Burroughs stood for in literature, gave them a little talk about him and his work, ending, by saying, "And this well-known author is now a guest in our city-you may see him on the street; he has a youthful step and young looking eyes, though his hair and beard are white-"

"I know," piped up a little lad, "I saw him yesterdayhe was in our yard stealing mangoes."

Mr. Burroughs enjoyed the great extinct crater, Haleakala, on Maui, more than he did the great active volcano, Kilauea. He soon tired of that boiling, tumbling, everchanging lake of fire which threw its fountains of molten lava sixty or more feet high.

After six weeks of lotus-eating in those tropic isles, we embarked on the Manchuria, laden with fragrant leis, and with a basket of the beloved mangoes; threw back our leis to the waiting friends on shore (in obedience to the 
346 JOHN BURROUGHS-BOY AND MAN

tradition that, so doing, one insures his return to those isles); while the tender strains of Aloha came floating to us, outward bound.

In the winter of 1911, Mr. Burroughs again went to California, Mrs. Burroughs accompanying him. Out of the previous trip grew the essays, "The Divine Abyss," "The Spell of Yosemite," and "Holidays in Hawaii." 


\section{CHAPTER XVIII}

\section{WORK AND PLAY IN LATER YEARS (CONTINUED)}

IF IT were possible for a house to be jealous, Slabsides would be jealous of Woodchuck Lodge, for since 1908, every summer and until late into the fall, the Hermit of Slabsides has forsaken his woodland cabin for a little farmhouse on the home farm near Roxbury in the Catskills. For two summers he simply camped out there with friends, but in 1911 made certain improvements, so that it has since been a comfortable midsummer home. Its roomy veranda, which admits of several cots, is a sleepingporch by night and a living-room by day.

In the orchard above is a little Bush Camp where he writes and dreams and looks off toward Montgomery Hollow. But oftener he writes in the old hay barn up the road, looking off into the woods that lead to Old Clump, and, like Thoreau, happiest the mornings when nobody calls (except a red squirrel or a chipmunk). In the afternoon he welcomes the friends who come from far and near to see the Laird of Woodchuck Lodge.

The "Barn Door Outlook," "A Hay-barn Idyl," "In the Circuit of the Summer Hills," and most of the essays in The Summit of the Years, in Time and Change, in The Breath of Life, and in Under the Apple Trees have been written either in the Hay-barn Study, or in Bush Camp.

One summer when an artist was painting his portrait in the barn. a junco built her nest in the haymow close 


\section{JOHN BURROUGHS-BOY AND MAN}

to them, thus beguiling the otherwise tedious time to the restive sitter. One summer, on his Boyhood Rock, he sat to Pietro, the sculptor, for a larger than life statuenow a superb bronze in the Art Museum in Toledo. During the sittings various members of the household were called up there to read to him and sometimes to help support his arm, the pose calling for one hand to shade his eyes as he looked across the wide valleys to distant Catskill peaks. As the clay statue grew to be almost a living thing, we used to feel guilty at leaving it up there exposed to cold and rain. One morning the sculptor found to his dismay that the cows had eaten away a part of the foot and ankle of the clay man. The sitter's concern, however, was chiefly lest the clay sicken the cows!

Woodchuck Lodge was so named because of the great number of those rodents that burrow in the fields and hillsides, and pilfer in the garden. "We are beleaguered by them," Mr. Burroughs often tells his callers, "and are forced to shoot them in self-defence." A youth who asked one summer if it was called Woodchuck Lodge because he protected the woodchucks, was somewhat taken aback by the reply, "No, but I'm going to make them protect me from the cold this fall." And leading him around to the woodshed, Mr. Burroughs showed him upwards of eighty marmot skins, home-tanned, stretched and drying on boards, and on the side of the house, some of which later went into a large rug for his cot, as others before had gone into rugs for the veranda floor. The choicest of the skins, after long hours of preparation-skinning the skin, and treating it with lightning tanner-were sent to a furrier and made into a handsome coat. While selecting and packing those skins for shipping, we heard him say 


\section{WORK AND PLAY IN LATER YEARS 349}

half to himself: "I shot him by the rock-that's the little cuss that got drowned out-these are the two big fellows I got below the orchard, so heavy I could hardly carry them up to the house-that's the black customer that came from Rose's Brook-he might do for collar and cuffs." People often marvel at the keenness of sight and surety of aim of the octogenarian Nimrod, and are staggered at the proof of his prowess.

After many years of living at Woodchuck Lodge, we learned how to cook the creatures so they are really a savoury dish. Hamlin Garland, who sometimes comes over from Onteora, feels aggrieved if a 'chuck is not on the bill of fare during his stay. Other guests, who, on being served with 'chuck, sit down to sniff, remain to pray -for more.

One day a caller, looking at the nearly finished statue previously mentioned, said in awed tones, "It seems symbolical, as well as being an excellent portrait-he is looking over a vast area, from a height far above the rest of us -what is that vision he beholds?"

"Most likely a woodchuck down in the beechwoods," retorted the sitter. And it is true that when posing for the statue, he would jump up unceremoniously and, gun in hand, march to a distant field, wait patiently if need be, and soon the crack of his rifle would tell us he had got it, or not, as the case might be, when he would come back and resume his pose.

There is much wild life to be seen on the old farm besides woodchucks. One day last August I saw J. B. coming toward the house with a long pole over his shoulder, a very long pole, at the end of which hung a skunk with foot caught in a trap. How gingerly he walked, how carefully 
he deposited his burden, letting it down slowly, almost reverently, into a barrel! At this stage everybody fled. He succeeded in releasing the creature's foot from the trap, but how should he get rid of him? Very carefully he laid the barrel down on its side, but the skunk hugged it closely. In most ingratiating tones he tried to coax "poor pussy," "nice pussy," forth, but to no purpose. Sir Mephitus would take his own time. In the morning the barrel was empty, and no harm done. I have seen Mr. Burroughs carry a skunk by the tail, but of course the trick is to get hold of the tail in time. There have been times when the experiment has terminated less favourably; then I have quite appreciated the name given the creature by a Scotch lassie who, shortly after coming to America, ran in to her mistress and told her the hired man had killed a stunk.

Mr. Burroughs is proud of his Catskill garden. He hoes in it diligently and fairly gloats over the telephone peas, the golden bantam corn, the Hubbard squashes, and other produce. One season a vine yielded him one hundred and forty-five pounds of squash. On sending Mr. Edison one of the biggest fellows, he asked him if he thought Mother Hubbard ever had anything in her cupboard to beat that.

One moonlight night in October, a few years ago, $\mathrm{Mr}$. Burroughs was awakened by a strident cry under the hill, about one hundred yards below the veranda on which he was sleeping, the like of which he had never heard before. It was so loud that it echoed in the woods four hundred yards away, tapering off into a long-drawn wail which for agony of soul, or hopeless longing, he had never heard equalled. "If a lost soul had been given a few hours' freedom, but had to be back in Hades on the stroke of mid- 
night, it might let off such a strident cry and hopeless wail as that." He was greatly puzzled as to its origin. None of the others sleeping on the veranda heard it, but the next night, at the same hour, a young couple sleeping upstairs, awakened by a similar cry, were so frightened they could not get to sleep again. A few years before, a woman guest and her son, a lad of fourteen, sleeping in the orchard in front of Woodchuck Lodge, had been frightened by a strange cry, which had sent them white and trembling into the house, though then Mr. Burroughs, not having heard it, ridiculed them, saying it was probably a fox barking; but when he himself heard this weird cry, he immediately thought of the one the lad and his mother had heard; and also of the report, that same year, of some young people on their way through the woods to a party, being so frightened by a wild, strange cry at midnight, that they and their horse were scared almost out of their wits. The people thereabouts firmly believe these wild cries came from a panther or puma, and Mr. William T. Hornaday, to whom Mr. Eurroughs described the cry, was inclined to think so, too,--probably a puma escaped from captivity-but Mr. Burroughs thinks if a puma were lingering in the mountains, it would have caused some depredations. That year, shortly after he heard the strange cry, he learned of a young farmer near him having seen a bob-tailed animal, as big again as a wild cat, come out of the woods, but as quickly disappear in them, and he thinks from the description that it was a lynx, and that that was the creature which, on occasion, makes night hideous in those peaceful hills by its unearthly cries.

One August day, several summers ago, Mr. Thomas A. 
Edison and family, touring the Catskills, motored fifty or more miles out of their way to call at Woodchuck Lodge, and later Mr. Henry Ford and a party of six came there to pick up Mr. Burroughs for a New England jaunt, liking the Lodge so well they tarried several days.

And in truth, Mr. Ford came back many a time after that, always pleased with the truly simple life of Woodchuck Lodge.

In $1913 \mathrm{Mr}$. Ford sent Mr. Burroughs a touring-car, and has kept him supplied with one ever since. He is now using his fourth car. The Walker took rather more kindly to the "contraption" than one would think, though having many a narrow escape the first year. Since he has become reconciled to the fact that one can really trace a bird's flight through bush and tree better on foot than when guiding a car, and has given up climbing trees and attempting other similar stunts with his car, he really enjoys it; and daily climbs in it the steep hills on the home farm, the hills up which he drove oxen as a boy.

At a week-end party at Onteora one October, Mr. Edison told us the story of the first try-out of the phonograph. After the long hours of experiment and doubt, enlivened only by incredulity and ridicule from onlookers, the inventor and his helpers were at last ready to test the invention: "When 'Mary had a little lamb,' actually came squawking out in human tones," said Mr. Edison, "the men were all amazed-and so was I!"

On someone asking Mrs. Edison if her husband drove his own car, she laughed outright: " $\mathrm{He}$ is the most awkward man with his hands I ever saw-he would run a car up a tree or in a ditch, if he tried to drive it."

When he heard his deafness referred to as a handicap, 
Mr. Edison said that, on the contrary, it had been a great advantage; it had shut him away from much that is annoying, and, he added with a twinkle, "I don't have to hear all the chatter around me, and I'm spared hearing telephone bells, and phonographs, and all those nuisances."

Several times in the last few years Mr. Burroughs has taken auto-camping trips with his friends, Messrs. Edison, Ford, Firestone, De Loach, and others, sometimes in the Adirondacks, sometimes down in Dixie. Once in starting out they camped one night in the orchard at Woodchuck Lodge, their green tents, lighted with electricity (for the Wizard carried his own battery) making a pretty scene in the old orchard. The movie men followed them about, and the reporters gave their own versions of happenings on these jaunts. A Rochester paper stated that Thomas A. Edison, the great electrician, Henry Ford, the automobile manufacturer, H. S. Firestone, of the Firestone tires, and John Burroughs of the adding machine were making a tour of the North Woods in automobiles!

On these trips Mr. Edison, a light eater, usually lectured Mr. Burroughs on his more liberal indulgence, urging him to cut out this and that-things that go down too easily, things that are not heated to 212 degrees Fahrenheit, things that are too cold, or too something or other. He cautioned him against sugar because it made crystals in the blood, and so on. But Mr. Burroughs turned on him for bolting his food, and eating pie by the yard, and taking black coffee, and smoking. "Cane sugar is bad for one, is it, Edison? But I notice you take two spoonfuls of it three times a day in your coffee-Oh, consistency, thy name is not Edison!" And Mr. Edison, like all truly great persons, acknowledged the corn: "I know 
coffee and smoking are bad for me, but I'm usually so good about my eating that I allow myself these little indulgences."

On returning from the summer outing in 1918 in the Great Smoky Mountains, Mr. Burroughs confessed that mountains and men who do not smoke please him far better. He said the wilder and rougher the roads were, the better Mr. Edison liked them, while he used to beg that they keep to the smoother roads: "You carry your shock-absorbers with you, Edison, but have mercy on us thinner mortals!"

One day when the fan to the Packard broke and punctured the radiator, their crew, and the workmen at the nearest garage, shook their heads and prophesied a long delay until a new radiator could be sent from Pittsburgh; but Mr. Ford said, "Give me a chance at it," and rolling up his sleeves, went to work. With drills and copper wire and gumption he had the damages repaired in two hours, and they were off again!

Their last jaunt had the best outfit of all, though the first one, several years ago-two big cars, two Fords, and two trucks, and a crew of seven men-was not exactly roughing it as $\dot{J}$. $B$. understood the term. In fact he called it a Waldorf-Astoria on wheels. In their second Adirondack trip, in 1919, a special feature was a Cadillac touring car with a covered body to carry the tents, cots, chairs, and so on, and a Ford with its body fitted like a travelling grocery, with drawers for food and dishes, a shelf which would slide out for the convenience of Sato, the resourceful Japanese cook; with gasolene stoves attached to the running-board, an oven, and many another convenience, by means of which they went far and fared sumptuously. 
One morning in camp when someone asked Mr. Edison if he would have some prunes, he replied, "No-I was once a telegraph operator, and lived in a boarding-house." Near one of their camps Mr. Edison handed out nickels to some children hanging about, wide-eyed and shy as partridges. When someone asked them if they knew his name, a little girl replied,"Yes-Mr. Graphophone."

Mr. Edison is a first-rate vagabond. He could go with ruffled hair and unbrushed clothes as long as anyone. Around the camp-fire he delighted them with his fund of stories, and wise and witty remarks. "He is as full of facts and formulas as an egg is of meat," said Mr. Burroughs. "His memory is like an encyclopædia." One night in telling them of the difference between white and black diamonds, and of the extreme hardness of the black ones, found only in Brazil, he said he had examined one which had been used for drilling ten miles through volcanic rock and that under a powerful lens it did not show the least sign of wear! Mr. Burroughs had known since boyhood the biting taste of the root of wild arum, or Jackin-the-pulpit, but did not know, until Edison told him, that its stinging effect upon the tongue is a mechanical one, due to tiny needles of the oxalate of lime. And familiar as he has always been with the skunk, it was reserved for Edison to tell him the name of the chemical compound which gives the potency to that odoriferous secretion. But when the Wizard attempted to dogmatize about Nature, asserting that in the inorganic world things go by even, and in the organic by odd, numbers, J. B. slipped away to the edge of the swamp below their camp and brought back the four-petalled flower of the galium, with its four leaves in a whorl. And he rubbed it in by telling 
him of the dwarf cornel, the housatonia, the evening primrose, and even of the whole order of the cruciferæ; of the four-sided stems of the mints; of the six-sided cells of the honey-bee, and so on.

Mr. Ford was as lively and happy as a boy from morning till night, chopping wood, climbing trees like a squirrel, kicking high, challenging some one to race with him, alert, hopeful, and good-natured under all circumstances and conditions. "A very likable man," said Mr. Burroughs, "as tender as a woman, and much more tolerant. Practical in all mechanical matters, an unconquerable idealist, he always seemed to be thinking of the greatest good for the greatest number of his fellows. He deplored every water-power he saw going to waste, and wanted to harness all those streams and thus make life easier for the masses."

The shadow of the Great War rested heavily upon the spirit of Mr. Burroughs from first to last. Following it with absorbing interest, he feared he would never live to see its end. Each day as the rural delivery man came all too slowly up the hill, he would go out to meet him, growl at him if he were late, seize the paper and devour the news, intolerant of any interruption. And when, as so often happened in those early months, everything seemed going the wrong way, he would fling the paper aside and rush out to the wood-pile, the savage blows of his axe the only fit outlet to his feelings. Or sometimes he would wreak his vengeance on the flies-" "Our grey-crested fly-catcher," as one of the family called him.

Long before we as a nation were sufficiently aroused to get in the War, he enlisted, and with trenchant pen dealt blows which made the enemy wince, judging from the in- 
sulting comments they called forth in German newspapers, and the abusive and threatening anonymous letters which came to him. Such attacks only egged him on. Again and again in those terrible years, he arraigned the enemy and voiced the undaunted purpose of the Allies. He returned to the charge again and again, and even after Germany cried quits, had a few things to say. Like a boy who has watched a bully get a good licking, but remembers countless scores that can never be wiped out, he kept nursing his wrath, declaring, long after the armistice was signed, that when he tried to think dispassionately of all that Germany had been guilty of during the War, he found himself getting hotter and hotter. Often during the war the very peace and repose of his native hills reproached him, and he turned in vain from one to another of his accustomed resources to assuage the terrible weight of the world woe.

A pretty episode in the fall of 1915 occurred in his"native town, in the midst of war's alarms. As an interlude in a pageant which celebrated the pioneer struggles of the More family in that vicinity, a charming Nature Interlude was introduced in which Roxbury paid a fitting honour to her Prophet in his own country.

The allegory (told in living pictures) was enacted on a grassy plain in an amphitheatre formed by the encircling hills, the Pepacton winding in and around the scene. It showed how Nature veils her wonders and beauties till one comes who can lift the veils and reveal mysteries beneath mysteries. Maidens in floating veils of varied tints and hues, symbolizing spirits of the earth and sea and sky, of the vales and hills, and of the seasons, disported them- 
selves across the grassy stage, then sank in slumber and concealment of the grass as the dreamy music, to which their dancing feet kept time, died away. Suddenly a hopeful strain was heard, and a bright creature in golden draperies appeared, wand in hand, symbolizing the Vision of Nature which it had been given to John Burroughs to behold, her wand the magic touch he has given to Nature's hidden beauties.

As she glided to the sleeping spirits of the earth and sea and sky, and touched them with her wand, slowly, gracefully, they arose, cast aside their enshrouding veils, while in their midst Nature herself awoke, arose, resplendent, alluring. Then from behind the shrubbery, summoned by the magic wand, came a joyous flock of birds and butterflies and all sorts of wingéd creatures, and creeping creatures, and hopping creatures, in one jolly, tumbling, skipping throng. Gliding to a distant point on the grassy stage, whence she had first emerged, the Vision again beckoned with her wand, and out from behind the screen stepped the living, moving John o' Birds. Humbly and reverently he approached the glowing Vision and followed her down the great green stage. Nature stepped down from her green mound and flitted and hovered near him, while all the shining hosts floated round Nature and her Interpreter as, moving across the stage, they were accompanied by the troops of children disguised as the dancing, skipping, flying, crawling denizens of land and sea.

During the winter of 1916, while Mr. and Mrs. Burroughs were visiting in Georgia, they became seriously ill. For him, recovery followed in a few weeks, but for 
her it was the beginning of the end, and after a year and more of wasting illness, in early March, 1917, in her eightysecond year, release came. They had been married fiftynine years; they had been young together; together they had lived through years of struggle and obscurity, her thrift, industry, and frugality contributing no small share to the material prosperity which marked their lives during and after the Washington period. For her the long journey was ended. It could not be long, he reflected, before Mother Earth would beckon to him also. At sundown, and in the long hours of the night, he often broods over the Past, and the days that are no more-a prey to the dark even as when he was a child in his Catskill home; but with the rising sun his buoyancy reasserts itself, and he faces toward the East, toward each new day, still finding life sweet, still saying from the summit of the years, "The longer I live, the more I am impressed with the beauty and the wonder of the world."

Journeying again to Southern California, in December, 1919, John o' Birds spent the winter chiefly in La Jolla, revelling in the beauty there of sea and sky; watching the pipits and ring-necked plovers on the lawn; the sea-gulls and pelicans on the shore; watching the hair seals playing in the waves, whose barking, heard almost any hour of the day or night, led him to call them "hounds of the sea"; observing the $e^{3}$ curious trap-door spiders whose ingenious nests he found on the beach; climbing Soledad; automobiling in the Imperial Valley; speaking to clubs and schools; tarrying awhile in Pasadena; touring other parts of the great wonderland of California; and then eagerly journeying homeward in the shining days of March to be on hand for his spring sugar-making. While in California 
he completed and sent to the publishers a new volume, Emerson and Thoreau. "Pacific Notes," a recent magazine article, an outgrowth of this trip, was also written there.

His eighty-third birthday found him with a jolly weekend house party at Yama Farms Inn. There he superintended the sap-boiling, planted a maple tree, walked in the woods, fished in Honk Falls, and basked in the crisp sunlit April air without, and in the abounding cheer and hospitality within. Sitting around the fire with his host and a circle of gathered friends at the close of the day he said: "I have had a happy life. My work has been my play, and I don't want a better world than this to play in, or better men and women for my friends."

The birthday festivities ended, he returned home to tackle the avalanche of accumulated letters, get his new volume (Accepting the Universe) off to the publishers, and welcome the returning birds.

Spring is already here at Riverby and celebrating her birthday, too. Pussy willows and spice bushes along the brooks hint it, skunk cabbages and spring peepers proclaim it, the toads trill it, the song sparrows blithely assert it, bluebirds warble it, robins chirp it, phœbe announces it, the flickers laugh it, even the crows caw iton every hand the world-old miracle is heralded anew. After a day replete with tokens of the Spring's new birth, John o' Birds seeks yet one more familiar evidence-the twilight mating song of the woodcock. On nearing the swamp we hear at first that harsh Seap, . . . . Seap, . . . Seap, as the bird moves about on the ground in search of worms. Presently the calls cease, and we are suddenly enveloped in a chippering sound as, rising in 


\section{WORK AND PLAY IN LATER YEARS 361}

wide circles, the bird mounts and mounts, showering down its rapid, rippling notes, now near, now faint, now lost for an instant, then near and nearer, more and more rapid-fine, hurried, ringing sounds ending in an ecstatic burst while in the zenith, after which the singer drops suddenly to earth and resumes his prosaic search for food. We wait for him to rise again on his singing wings, again listen to that joyous downpour, and yet again-elusive twilight song, born of the passion and ecstasy of spring! But darkness falls, the song is hushed, the stars come out, and picking our way through the low marshy ground, we seek the light and warmth and shelter of The Nest.

THE End 

I N D E X 



\section{N D E X}

(The abbreviation "B." refers to the subject of this book)

"Aaron." See Johns.

A-b abs. See Alphabet.

Abbey, Henry, 213.

Abel. See Cain and Abel.

Abraham, Plains of, 322 .

Accepting the Universe, 360 , alluded to, 328.

Adam, 46, 170. Adam's ale, 63.

Adamana, Arizona, 341.

Addison, Joseph, 178.

Adirondack's, B.'s first camping in, 220,225 ; auto-camping trips in, $353,354,355,356$.

Adventists (Millerites), 150, 151.

Aeroplane, B.'s ambition to ride in, $10 ; 56$.

Africa, lions in, 340; plover in, 338.

Akers, Elizabeth, 258.

Alabama, 221.

Alaska, 290, 341; B.'s journey in, 324-327; birds seen in, 326: humming bird, Oregon robin, golden-crowned sparrow, Lapland longspur, albatross, Arctic tern, water ouzel, golden plover, barn swallow, song sparrow. See also Glaciers.

Albatross, 326.

Alcott, Bronson A., 217.

Aldrich, Thomas Bailey, 3.

Alexandria, 204.

Algebra, 94, 148.

All Souls, early pen-name of B., 192. Allaben, Bill, 140, 141.

Allen, E. M., comrade of B., 191, $220,225,227,228,236,258$, $318,319,320$; description of, 192 ; B.'s verses to, 192; encourages and criticizes $B$.'s writings, $194,196,208$; camping out with, 192, 195, 318, 319, 320; introduces B. to Leaves of Grass, 192; berry-picking, 196; urges B. to come to Washington, 201, 202; marriage to Elizabeth Akers, 258; quoted, 199, 202, 203-207, 208, 215, 216.

Allen, Clapp \& Co., 203, 225, 227, $228,232,236$.

Alphabet, B. learning the, 32, 33.

Amassa. See Martin.

Ambrotypes, 45, 46.

Ambulance and mules, 333.
America, 12, 238, 285, 350; North, 122. American, an unsophisticated, 264-271. See also United States.

American Boy's Handy Book, 302.

American locust (Schistocerca americana), 224.

American Museum of Natural History, New York, N. Y., 338.

American river, 149.

Amherst Glacier, 325.

"Anaconda" policy, 221.

"Analogy," 213.

Anatomy. See Gray.

Anderson, Gen. Robert, 244.

Andes, N. Y., 130, 133.

Angling. See Trout flshing.

Anough. See Indian.

Anti-rent War, 123-133, 142.

Anti-renters. See Anti-rent War.

Antietam Creek, 209, 210.

Antiquities, anecdote concerning, 147.

Ants, 45 .

Antwerps and war news, 196, 197.

Apple, 6, 8, 16, 27, 72, 84, 103, 111, $113,114,115,133,135,142,156$, 237, 273, 305, 309; apple-cuts, $72,142,156,157,170$; applegathering, 9, 113, 114, 273; apple-hole, $113,114,115$; apple tree, 5, 8, 9, 81; the old gill-flower tree, 296, 309 . See also "The Apple," Under the Apple Trees, and Orchard. "Apple, The," 6, 7, 8, 16.

Appomattox. See Grant.

Arbutus, trailing, 215, 278, 288, 310.

Arctic tern. See Tern.

Arizona, 336, 340, 341; desert in, $341,342$.

Arkville, N. Y. (Dimmick's Corners), $7,16,161,174,316$.

Armenians. See Methodists.

Army of Potomac. See Potomac.

"Art of Seeing Things, The," 324.

Artemus Ward. See Browne.

Arum. See Jack-in-the-pulpit.

As Seen from the Ranks. See Charles E. Benton.

Ashland, N. Y., 58, 167, 169. See also Hedding Literary Institute.

Ashley, Mrs. Maurice C. ("Mrs. $\mathrm{A}-$ "), $340,341,343$. 
Ashokan reservoir, 165.

Asia, 327 ; Czar of, 327.

Asters. See Wild Honey.

Athenians, 217.

"A Thought on Culture," quoted from, 193.

Atlanta, Georgia, 242.

Atlantic Monthly, 195, 196, 197, 198, $199,207,209,225,226,330$.

Atlantic Coast, 289; ocean, B. crossing the, 262 .

Auchmoody Pond, camping-out on, 280.

Audubon, John James, 217, 218, 236; his Birds stimulated B.'s bird study, 217, 218. Life of, by B., 328 .

Aunt Abby. See Kelly.

"Aunt" Debby and Sabbath breaking. See Scudder.

"Aunt"; Dolly and seedling pears, $73,74,273$.

Aunt Mary, 64.

Aurora borealis, 321.

Austrians, 140.

Author's association with B., 328 , 330.

Auto-camping trips, 9, 353, 354, 355,356

Avery, Great-grandmother, anecdote concerning, 15.

Avery Rachael. See Burroughs.

Avon. See Stratford-on-Avon.

Ayrshires and Durhams. See Dairy herd.

Babel, 41, 108.

Bad Lands. See Dakota.

Baker, Dr. Frank, 258, 260, 261.

Baking-day, 65, 66 .

Baldwin, The, 190.

Balsam Lake, 319. See also Beaverkill, camping-out on.

Baltimore, 213.

Band of Mercy, 306.

Bank Examiner. See National Bank Examiner.

Bank of England, notes of, 268.

Banks, Gen. Nathaniel Prentiss, 203.

Bannockburn, 129.

Baptist, Old School, 78, 79, 80, 81.

Barber, Dominie, 167.

Bark-a-boom, 317.

Bark-peeling, 52-54, 71, 72, 310 .

Bark Study at Riverby, 4, 6, 10 $278,292,300,304,305,309$. 329.

“Barn Door Outlook, A," 347. See also Hay-barn Study.

Barn-raisings, 106, 107, 195.

Barry Glacier, 325.

Bartram, Widow, 15, 16; Eleanor $34-35,157,158$; Jim, 157; 'Riah' (Uriah), 34, 40 .

Bass wood whistles, 302.

"Batahvy kill." See Batavia.

Batavia, N. Y., 129; mountain, 159.
Battle Above the Clouds. See Hooker.

Battle of Gettysburg. See Gettysburg.

"Battle of Lundy's Lane," hero of. See Rose Mary Rose.

Battle of the Wilderness, 234.

Beacon Biographies. See Audubon.

Beans, hoeing, 9, 89.

Bear (Bruin), 11, 103, 280.

Bearsville Creek, Battle of, 61, 62.

Beauregard, Gen. Pierre G. T., 244.

Beaver, 3, 4, 16, 285; colony of, 3; dam, 3. "Beaver Dam." See Roxbury

Beaverkill, N. Y., 142; campingout on, 195, 205, 216, 318, 319.

"Bed of Boughs," 6 .

Beds of Auld Lang Syne, 76, 77.

"Bee" A, 15. See also A Moving, and Quilting party.

Bee. See Honey-bee, and Bumblebee. Bee-tree. See Honey.

Beecher, Henry Ward, 187.

Lake. See Thomas Lake.

Beechwoods. See Deacon woods.

Belgium, 196.

Benjamin, Parke, 178.

Benton, Charles E., 211; his As Seen from the Ranks, 211, 213 , 221.

Myron B., a close friend of B., $209,210,214,216,217,220$, $221,222,228,230,243,259$, $260,272,273,276,280,297$, 316; quoted, $210,211,213,214$, $221,222$.

Bering Sea, 326, 327.

Bermuda, 330.

Berry-gathering, 8, 21, 47, 53, 63, $71,72,185,196,197,273$.

Bible, 14, 18, 19, 41, 82, 152, 172.

Big Rock. See Boyhood Rock.

Thunder. See Squires.

Billy Hofer. See Hofer.

Binocle, 317.

Birch, 322: bark canoe, 316, 322 ; uses of in camping, 322, 323. "Birch Browsings," 6, 259.

Bird and Bough, 327; alluded to, 328.

Bird highwaymen, or human weasels, 312

"Bird Man." See Nicknames of B.

Bird-nesting, 9, 312.

Birds. See Audubon.

Birds, B.'s early memories of, 25, 30 , 35,36 ; early interest in, 35,217 , 218: interest stimulated by Audubon, 217, 218; first articles about, 220, 225, 226.

"Birds and Bees," compiled from B.'s works, 5 .

"Birds' Eggs," 6; collecting of, 6, 312.

"Birds, John o" ". See Nicknames of $\mathrm{B}$. 
Birthday, Eighty-third. See Yama Farms Inn.

Birthplace of $\mathrm{B}$. See Roxbury, and Old Home. See also A Moving.

Blackberry, 53, 72. See also Berrygathering and Fruit-gathering.

Blackbirds, 234 .

Black Creek, or Shattega, 299, 301, 324 ; Pond, 284, 302.

Black-tailed deer. See Deer.

Blair's Rhetoric, 169.

Blasting, 106.

Blind girl reading, 41.

Bloodroot, 278, 288.

Bloomville Mirror, B.'s first appearance in print in, 176, 177, 179.

Bloomville, N. Y., 142.

Blue Coat. See Bluebird.

Bluebird, 6, 8, 104, 287, 309, 334, 360 ; nest of, 104 .

Blue Grass region, 281.

Blue grouse. See Grouse.

Blue Mts. of Jamaica, 329.

Boarding round, $160,165$.

Bob-cat, 331.

Bobolink, 8, 47, 63, 64, 71, 96, 234, 326 ; nest of, 47 ; mimicry of, 63 .

Bob-tail, Old. See Dairy herd.

Bogart, E., quoted, 169, 170.

Bolshevism, 182.

Booth, John Wilkes, 244.

Boston, 122, 327; rocker, 27.

Boulder, 46, 48, 297.

Bouton, Gould, 38; Jerry, 81, 82; Rice, 107; Hi, 136.

"Bowery Girl," a sailor's ditty, 157.

Boy correspondents. See Tom Brown.

Scout, 3, 4, 53; Scout Master, 3, 4, 318. See also Brigand steak. -shepherd, 8.

Boyhood Rock, 46-49, 57, 87, 348; Boyhood, rose of, 48 .

Boys and Bees. See Bumblebee.

Bradt Patent. See Anti-rent War.

Brag Hollow, 79.

Bragg, Gen. Braxton, 221, 227.

Brazil, 355.

Breakneck Stairs, 290.

Breath of Life, The, 347.

Brick oven. See Oven.

Brig o' Doon. See The Doon.

Brigand steak, how to make, 4; at Riverby, Slabsides, and Woodchuck Lodge, 4,5 .

Bright Angel Trail. See Grand Canyon of the Colorado.

Brindle. See Cow.

Brindled Heifer. See Dairy herd.

British Army, officer of, 339.

Brock and Bright. See Oxen.

Brockleface, Old. See Dairy herd.

Brown, John, 188.

Tom, B.'s letter to, 306.

Browne, Charles Farrar (Artemus Ward), 202.
Bruin. See Bear.

Bryn Mawr Glacier, 325.

Buckle, adventures with a, 185-187, 189-191.

Buell, Gen. Don Carlos, 221.

Buffalo Grove, Illinois, 181, 182.

Bull Run, 197; second battle of, 208.

Bumblebee, 88; honey of, 88.

Bunting, indigo, 103.

Burhans, Ham, 145.

Burning stumps, 104, 200.

Burns, Robert, 154, 280.

Burnside, Gen. Ambrose Everett, $210,213,214$; his army, 234 .

Burroughs, Abigail, sister of B., 30 , 46,60 .

Amy (Kelly), mother of B., 8, 20$21,26,28,29,30,31,32,38,40$, $45,46,56,58,60,61,62,65,66$, $68,69,70,73,75,76,78,93,95$, $100,102,128,148,153,154$, $159,160,161,168,286$.

Chauncey A., father of B., 3, 8, 14, $15,20,21,26,27,28,34,35,38$, $39,40,45,51,56,57,58,59,60$, $64,70,71,74,78,80,81,82,83$, $87,90,95,97,100,102,104$, $106,107,111,112,119,120$, $126,128,147,148,153,154$, $159,161,167,168,172,193$, 212, 319 .

Curtis, brother of B., 31, 39, 40, $56,60,73,82,89,90,94,97$, $111,115,116,117,119,181$

Eden, grandfather of B., 14, 15, $16,17$.

Eden, brother of B., 31-32, 39, $60,67,68,69,75,82,83,88,90$, $104,115,116,117$.

Edmund, brother of $B$., died in infancy, alluded to, 21

Elizabeth, granddaughter of B., alluded to, 292.

Emily (MacKay), wife of Julian B., alluded to, 292, 329.

Ephraim, great-grandfather of B., $12,13,14,230$.

Evaline, sister of B., died in infancy, 46.

George, the reverend, victim of Salem Witchcraft, 13.

Hiram, brother of $B ., 31,37,39$, $56,60,72,73,82,90,91,106$, $110,117,137,141,152,156$, $168,287$.

Jane, sister of B., 29, 46, 60, 73, 74, $156,157,184$.

John, subject of this book, which see.

Burroughs, John, date of birth, 3 , 15,244 ; birthplace, 15, 107. 108; forebears, 11-21.

Early memories: fear of hawk, 25; fear of dark, $28,54,55,96,158$, $240,319,359$; first grief, 25-26; picture of old kitchen, 26-29, $30,31,32$; first journey from hearthstone, 32,161 ; flrst day 
at school, 32; learning his letters, 32, 33; first betrayal, 33, 34; flrst sweetheart, 34-35; early bird memories, $23,30,35$, 36; Harrison-Tyler campaign, 29-30; spring peepers, 36,37 ; the old Doctor, and teeth-pulling, 38-39; first circus, 40-42.

Boyhoodexperiences: memory pictures, 45-46; Boyhood Rock, 46-49, 57, 87; home-made toys and sports, $37-38,49,50,137$, 138; kite and mouse, 50; darts and cross-guns, 50-51; in the bark-peeling, 52, 53, 54; fear of ghosts (spooks) and hobgoblins, $18,25,54,62$; flrst partridge shot, 57 ; the ride to Catskill and its wonders, 55-60; the battle of Bearsville Creek, 61,62 ; a glorious Fourth, 6264 ; getting oven wood, 65,66 ; helping in dairy work, 66-68; at candle-making, 69 ; at soapmaking, 70-71; fruit-gathering, 71-74.

Chores and pastimes: salting sheep, 83; the dairy herd, 83, 84; driving cows, 85,86 ; $a b-$ sorbing natural history, 85,86 , 87; yoking up oxen, 87-88; chasing bees, 88; hoeing beans, 89 ; sugar-making, 89-94; troutflshing, 95-98; driving sheep, 99; gathering flax, 100, 102, 108; salting young cattle, 102, 103; burning stumps, 104; picking up stone, 105, 106; turning grindstone, 110; haying, 109 , 110; threshing, 111, 112; applegathering, 113, 114; 'coon-hunting, 115-117; hunting foxes, 118, 119; an obtrusive mitten, 119; pigeon-hunting, 120,121 ; B. plays Paul Pry at a gathering of "Indians," 127; attends an Anti-rent meeting, 128, 129; 132,133 ; boyish periods of exaltation, 139.

School days: in Old Stone Schoolhouse, $32-34,134$; in West Settlement, 134-154; boyish ambitions: a coveted slate pencil, and the curly hair of a school fellow, 136; foot-paths and natural history, 134, 135; winter sports, 137, 138; games and riddles, 138, 139; books in library, 139, 140; teachers and schoolmates, $140-146$; two West Settlement boys who achieved renown, 143, 144; how B. earned his algebra and rhetoric, 93, 94, 148; acquiring a vocabulary, 146, 147; Gold Fever breaks out in Roxbury, 149 , 150; end of world predicted,
150,$151 ;$ B. attends lectures in village, 147, 148, 149, 152; a plough-boy's dreams, 153-155; thwarted hopes, 153-155; apple-cuts and quadrilles, 156 157; a bashful swain, 157; B.'s flrst courting, 158, 159; three months at Hedding Literary Institute, 167, 168; studies and experiences at, 167, 168; bent toward writing develops, 168 ; debating clubs, $169,171,177$, 178,191 ; letter from schoolmate, 169, 170; an early notebook, 152, 170-172; interest in phrenology, 142, 143, 166, 172; composition writing, 168, 172; attends Cooperstown Seminary, 177; studies at, 177; excels in composition, 177; school days end, 179.

Schoolteaching: at Tongore, N.Y. 165,166 ; boarding round, 165 , 166; at Tongore again, 176; at Buffalo Grove, Illinois, 181, 182, 183; at High Falls, N. Y. 184; at Rosendale, N. Y., 185; at East Orange, New Jersey 187; at Marlboro, N. Y., 196; at Ólive, N. Y., 212; at Buttermilk Falls, N. Y.., 212, 213, 214, $220,222$.

Signal events in youth and early manhood: first leaving home, $159,160,161,162$; first ride on steam cars, 173; first trip to New York, 173; purchase of second-hand books, 173, 174, 175; philosophical reading begins, 173-175; meets his future wife, 176; begins essay writing, 176; flrst appearance in print, 176; sees his first author, 179 ; comes under influence of Emerson, 182; second appearance in print, 182; marries Ursula North, 184; makes an unlucky business venture, $185-187$; seeks business career, 186, 193. 194; B.'s fortunes paralleled with those of the young nation, $188,189,194,214,227,229$, 230, 244; flnds a comrade, 191 ; first camping-trip, 192, 195, $205,216,318,319$, 320; reads Leaves of Grass, 192; Atlantic accepts "Expression," 195; raising onions, 203, 233; speculates in honey, 211; forms friendship with Myron B. Benton, 209; reads medicine for a time, 212, 213, 223; writes "Waiting," 212; meets Professor Eddy and begins study of botany, 214, 215; meets Emerson, 216, 217; comes upon Audubon's Birds and begins bird study, 217, 218; Adiron- 
dack camping-trip, 220; flrst bird articles written, 225, 229; begins life in a city, 224. See also Life in Washington.

Life in Washington: 224-272; early struggles and economies, 225,233 ; flrst bird article published, 226; work in Quartermaster General's department, 226; how he loses his job, 226, 227 meets Walt Whitman, 228; obtains clerkship in Currency Bureau, 229; appointed keeper of the vault, 231 ; writes articles which later go into Wake Robin and Winter Sunshine, 231; Sunday walks and ornithology, 233, 234, 236; fraternizing with Grant's veterans, 239, 240; going home to vote, 242, 243; living on Capitol Hill, 243, 245, 246; Chloe, 247, 248; stolen chickens, 250 , 251: the forged bank-notes, 255-258; new friends, 258; flrst book published, 258, 259; living in V-Street, 259; magazine writing, 259,269 ; publication of Wake Robin, 261; first trip to Europe, 261; London experiences, 262-271; meets Carlyle, 263, 264; hears skylarks, and journeys in France and Ireland, 271 ; resigns from Currency $\mathrm{Bu}-$ reau and quits Washington, 272.

Living at Riverby: Fruit-farming and bank-examining, 273,274 , $276,278,279,281,282,283$ (see also Vineyards at Riverby); river experiences, 276-278; sauntering and writing, 278, 279; frequent camping-trips, 279,280 ; second trip to Europe, 280, 281; lesser journeyings, 281; outwitting the grape thieves, 283, 284; his son a comrade, 284, 398-305; building of Slabsides and housekeeping there, 285-287, 288, 289 . $290,291,324$; invaded by visitors, 288; John Muir's visit, 289, 290; visit of President and Mrs. Roosevelt, 290-293; dog and cat friends, 294-301; combining work and play and the study of natural history, 307 . 308 , et seq.; his chum, Channy. 243, 310, 311, 320; takes Pepacton voyage, $7,279,316,317$.

Camping out: on the Beaverkill, 318, 319; on Thomas Lake. 320 ; on the Neversink, 320 , 321; on Peekamose, 321; on Furlow Lake, 280, 321 ; in Canada, 321, 322; in Maine, 279. 323. Journeyings in later years: To Alaska, 324-327; to Jamaica, 328, 329; to Bermuda,
330 ; in the South, 330, 358; to the Pacific Coast, 330, 340, 346. 359; yachting around Cuba, 330 ; in Yellowstone Park, 331337; at Pine Knot, Virginia, 338-340; in the Southwest and in Yosemite with John Muir, 340-344; in the Hawailan Islands, 345; auto-camping trips, $9,353,354,355,356$. Naturefaking controversy, 330, 331 , 338; Slabsides deserted for Woodchuck Lodge, 347; midsummers at Woodchuck Lodge, 347-352; the shadow of the World War, 356, 357; flghting with his pen, 356,357 ; his literary output, 328; (see also Books by B.); Nature Interlude in Roxbury Pageant, 357, 358; death of Mrs. Burroughs, 359; eighty-third birthday celebration, 360; latest book off for publication, 360 ; Spring at Riverby, 360, 361 .

Traits and Characteristics: A grown-up boy, 3-10, 56; young at eighty-three, 3,349 ; love of home and family, 8, 26; most loves things near home, yet eager about new lands, 9, 32, $324,341,345$; a lover of peace, 9,297 , but can flght with the pen, 9, 356, 357 (see also "Real and Sham Natural History" ); doesn't lose enthusiasm, 3, 8, 9, $56,97,98$; work has been play, 78; "dreamy shirking ways," 19; petulant and inclined to sulk (self-confessed traits), 15; thrifty, 19; fear of the dark, 28, $54,55,96,158,240,319,359$; a dreamer, $8,46,47,57,81,94$, $95,120,154,347$; " an odd 'un,' 21,38 , 148; making ambrotypes, 45,46 ; likes books of travel and adventure, 9, 139; youthful periods of exaltation, 139; self-description, 166, 219; self-criticism, 172, 209, 213, 219; an independent thinker, $151,152,168,169,177$; a hater of shams, 177, 330; philosophic trend in youth, 47, 166, 182; vim and gumption, 82 ; homesickness, 160, 161, 167, 187, 228, 229; love of comrades, $167,179,181,221$; strong leaning to feminine society, 179, 181 ; tendency to reminiscence, 181 ; sentiment and practicality, 181, 188; early development of critical faculties, 176 , 177; belief in self, 185, 194, 195, 196,212 ; constitutional shunning of strife and warfare, 219 , $239,240,297$; his service to his country, $219,220$. 
B. quoted: on brigand steaks, 4; how he learned to write about strawberries and apples, 8; a childish escapade, 29; his first sweetheart, $34-35$; making memory plctures, 45,46 ; Boyhood Rock, 46-49; the rent collector, 125; envying a schoolmate his curly hair, 136; Cuff's attack on John Shout, 136; on learning to write, 137; on his sensitiveness to eloquence, 139 , 140; on his schoolmates, 142, 143,145 ; on reminiscences of Jay Gould, 143, 144, 145, 146; on exonerating his father for breaking his promise, 154, 155; concerning youthful aspirations, 155; on Harpersfleld, 155; on a cow falling in a cistern, 168; a school-boy essay quoted from, 177, 178; also a schoolboy letter, 180, 181; on eating or not eating, 180 ; on revolutions, 182 ; on self-development, 183,185 ; on riches, 187 ; on unrest and aspirations, 188 ; extract from "A Thought on Culture," 193 ; on sum earned by "Expression," 198; on Civil War matters, 209,210 ; on prospective meeting with Myron Benton, 211; on the effect of Audubon upon him, 218; on his peace-loving nature, and on what he missed in not being a soldier, 210; arranging for Adirondack camping trip, 220; on meeting Whitman, 228; on his lack of recommendations, 229; on the dandelion, 230 ; in selfcondemnation, 234 ; on his one night bivouac at Fort Stephen and his lack of bravery, 239 , 240; on urging M. B. B. to come to Lincoln Inaugural, 243; on going to the woods instead of to Inaugural, 243; on the recovery of his stolen chickens, 251; on his V Street home, 259; on seasickness, 262 ; on sightseeing in London, 263 ; concerning the Hudson, 276; bloodroot, 278; on his Bark Study, 280; concerning Lark, 296, 297; Laddie, 298, 299; Rose Mary Rose, 295,296 ; doggerel, 297; on dogs, 294; a letter to Tom Brown, 306; experiences on first camping venture, 319,320 ; on a wren's nest, 312 ; on a cuckoo's nest, 312; on wild honey quests, 316 ; on glaciers, 325; on Asia, 327; on the song of the solitaire, 329 ; on wanting to shoot a cougar or a bob-cat, 331; on a Wild West send-off, 333 ; on woodchucks, 348,349 ; on the cry of an unknown wild animal, 350, 351; on "jollying" Edison in camp, 353; on rough roads, 354 ; on Edison, 355 ; on Henry Ford, 356; on the beauty and the wonder of the world. 359 ; on his happy life and his contentment with the universe, 360.

Early efforts at writing: Farmboy experiences helped him to write, $7,8,199,200,209,232$; never could write to order successfully, 146; flrst bent toward writing, 168; composition writing, 168, 172; "Work and Wait," 177, 178; models essays on Johnson, 176; first appearance in print, 176, 177; flrst essays of philosophic trend, $176,177,182,193,195,199$; Johnsonian style abandoned, and influenced by Addison and Lamb, 178; "Revolutions" quoted from, 182; early pen names: Philomath, 176; All Souls, 192; early verses, 192 , 212 (see also Verse writing); unconscious imitation of Emerson, 195, 198; "Expression," 195, 197, 198; first money earned by writing, 198; writes philosophical fragments for Saturday Press, 192, 193; tries to swing away from Emersonian style by writing on country themes, 199; "From the Back Country," in $N$. Y. Leader, 208, 209 ; writes "Waiting," 212 ; Knickerbocker accepts" "Analogy," 213; first bird article written, 220; first book on Walt Whitman, 258, 259; magazine writing in Washington, 259 , 260 ; first nature book published, 259, 261.

Books by B. Notes on Walt Whitman, Poet and Person, 258, 259; Wake Robin, 220, 231, 259, 261; Winter Sunshine, 231, 233; Birds and Poets, alluded to, 328; Locusts and Wild Honey; alluded to, 328; Pepacton, 316; Fresh Fields, 328 ; Signs and Seasons, 328; Indoor Studies, 328; Riverby, 274; Whitman, a Study, 328; The Light of Day, 328; Literary Values, 328; Life of Audubon, 328; Far and Near, 324, 326; alluded to, 328; Ways of Nature, 328, 330; Bird and Bough, 327; alluded to, 328 . Camping and Tramping with Roosevelt, 328; Leaf and Tendril, 324, 328; Time and Change; alluded to, 328, 347; The Summit of the Years, 328, 347; The Breath of Life; alluded to, 328 ; 347; Under the Apple Trees; 
alluded to, 328, 347; Field and Study, 6; alluded to, 328 ; Accepting the Universe; alluded to, 328; 360; Emerson and Thoreau; alluded to, 328,360 .

Burroughs, John, the younger, grandson of B., 9; alluded to, 292.

John C., nephew of B., 313, 314, 315.

Julian, son of B., 277, 279, 280, $282,284,288,289,290,291$, $292,294,297,298,301,302$, $303,304,305,327,328,329$; family of, 292 .

Olly Ann, sister of B., 32, 62, 112, 113.

Rachael (Avery), grandmother of B., $14,15,16,17$.

Stephen, English navigator, 11.

Stephen, astronomer, inventor, ship-builder, $12,230$.

Stephen, an adventurer, 12, 13.

Ursula (North), wife of B., 176 , $183,184,185,186,187,188$, $190,193,196,197,198,202$, $208,212,213,214,222,227$. $229,232,233,239,243,245$, $247,249,259,261,262,276$, $280,284,291,292,304,330$, $346,358,359$.

Ursula, the younger, granddaughter of B., alluded to, 292 .

Wilson, brother of B., $31,34,56$, $73,82,115,116,117,168$.

Mountain, i4. See also old Clump.

Bush Camp, 96, 347. See also Woodchuck Lodge

Butcher bird. See Shrike.

Butter, 56, 58, 59, 60, 68, 159, 167, 290

-making, 199. See also Dog-churn.

Buttercups, 96.

Butterflies, 5, 103, 358.

Buttermilk Falls; N. Y (now Highland Falls), 212, 213, 214, 220, $222,227$.

Buttes, 342 .

Buzzards, 233.

Cab and caboose. See Munroe.

Cabin, John Bridge, 235.

Cadillac touring-car, 354.

Cain and Abel, 81 .

Cairo, N. Y., 58.

California, 149, 150, 341, 346, 359.

Cambrian plateau. See Grand Canyon of Colorado.

Camden, New Jersey, 279.

Cameron, Simon, 207.

Canada, 279, 321, 322. " Halcyon in Canada, The," 322

Candle-light, 26, 27, 29, 31, 70, 129, 156.

-making,69-70; candle-sticks, 70.

Cap, stolen, 25, 26; of musk-rat fur 60,61 ; alluded to, 58 .
Cape Eternity, 322.

Cape North, 11.

Cape Trinity, 322.

Capital. See Washington.

Capitol, 233, 234, 249; dome of, $235,246$.

Capitol Hill, B. keeping house on, $243,245,246,247,249,250$; garden on, 246.

Carbuncles, 208.

Carcassonne, 155.

Caribbean Sea, 329.

Caribou, 323, 331, 338.

Caricature of B., 5 .

Carlyle, Thomas, 198, 263, 264; country of, 280.

Carpenter, The. See O'Connor.

Cars, B.'s first sight of, 59 ; flrst ride in, 173 .

Cat, 154, 259: pets of B, 300-301. Nig, 5, 300, 301; Tom Tinker. 300, 304, 305; Silly Sally, 287. 300 ; wild, 351 .

Catbird, 234, 318, 326.

Cat-tail penholders, 302

Cator, George H., 142; Liberty, 137.

Catskill, N. Y.. 55, 56, 58, 59, 159 , 167; Mountain, 59; Point, 60.

Catskills, The, 3, 4, 14, 105, 118 , $121,165,193,198,202,209$, $259,272,275,278,279,321$, $326,347,348,350,352,359$.

Cattle. See Cow. See also Dairy herd.

Celtic inheritance, 16, 17.

Centennial, 279.

Chancellorsville, 210.

Channy. See Deyo.

Chapin, Edwin Hubbell, 187.

Chapultepec, 147.

Charlestown, 244.

Charlotte Temple, B.'s first novel read, 176.

Chase, Neighbour, 83

Salmon, Portland 230.

Chat, yellow-breasted, 290.

Chattanooga, 221, 227.

Chaucer, Geoffrey, 178.

"Cheese." See Cider-making.

Cheese-making, 68 .

Cherries and bird thieves, 284.

Cheyne Row. See Carlyle.

Chicago, 183.

Chickadee, 288; nest of, 311.

Chickamauga, 221.

Chickens and turkey stolen, 250. 251.

Chilblains, 134.

Chinquapin Falls, 343.

Chipmunk (Stripe Coat), 5, 6, 51 $90,170,231,300,301,304,335$. 347.

Chloe. See Cow

Chores, 37, 42, 81, 89, 99, 102, 200; Chores and Pastimes, 81-122.

Church, going to, 77-80. See also Old Y ellow Meeting-house, and Old School Baptist. 
Cider-making, 115.

Cincinnati Zoological Society, 122.

"Circuit of the Summer Hills, In the," 347.

Circus, B.'s first, 40-42.

"City and City Life." See Allen.

Civil War, 201, 202, 208, 209, 210 . $214,215,219,220,221,222$, $223,227,233,234,238,239$, $240,241,242,244,258$. See also Allen's and Benton's letters, and As Seen from the Ranks.

Claytonia, or Spring beauty, 215.

Clemens, Samuel Langhorne (Mark Twain), quoted, 3.

Cleveland, Grover, 273.

Close, 320.

Clump, Oid. See Old Clump. See also Burroughs Mountain.

Clyde river, 280.

Cobbs' Spelling-book, 33.

Cock Pit Country, 329.

"Coffee and Cakes." See Allen.

Colfax, Schuyler, 260.

Collins, Wilkie, his Woman in White, 264.

Colorado river, 342. See also Grand Canyon of Colorado.

Coloured man. See Negro.

Columbia Glacier, 325.

Columbus, Christopher, 285.

Combe, his Constitution of Man, 195. See also Phrenology.

Commercial Bank of New York, 146.

Company Training. See Training.

Comptroller of Currency. See McCulloch.

Concord, Sage of. See Emerson.

Concord stage-coach, 159, 160, 161, 174,175 .

Confederacy, 218, 221, 244; Confederates, 201, 221, 239.

Connecticut, 12, 13; river, 322.

Conquest of Peru. See Prescott.

Constitution of Man. See Combe. See also Phrenology.

Conway, Moncure, 263, 264.

'Coon, 19, 29, 53, 115, 116, 117, 135 . 302, 304, 305; 'coon-hunting, 115-117.

Cooper Union, Lincoln's speech at, 194.

Cooperstown, N. Y., 177, 179, 180 , 181 ; Seminary at, $177,178,179$ 180: studies at, 177.

Copperhead, 242.

Corbin, Andrew, 142.

Corinth, 210.

Cork, Ireland, 271.

Cormorant, 261.

Cornel, dwarf, 356.

Corn-shelling, 31, 32.

Corydalis, 215.

Cougar, 331.

Count of Monte Cristo. See Dumas.

Courting customs in B.'s youth, 158, 159.
Covert, Hudson ("Hud"), 282, 305.

Cow, 7, 9, 20, 40, 48, 53, 59, 83, 84, $85,86,90,91,102,103,104$. $114,152,200,246,247,248$, 317, 327, 348; Devonshire (Chloe), 246, 247, 248; at Ashland, 168; cow-pasture, 48,85 . 200. See also "Our Rural Divinity."

Crackle, 101.

Cream-pan tree. See Sugar-bush.

Crickets on the hearth, 31 .

Crimean War, subject of debate. 169.

Crinkle root, 135.

Crosus, 174.

Cromer, Lord, his book on Egypt, 340.

Cross-guns. See Darts and Crossguns.

Crows, 57, 91, 233, 308, 309, 360.

Crucifer $\mathscr{X}$ (Mustard family), 356.

Cuba, yachting around, 330.

Cuckoo, black-billed, nest of, 312 .

Cuff, Old. See Dog.

Cunard line, 262.

Currants. See Fruit-farming.

Currency Bureau of Treasury Department, 146, 229, 230, 231, $232,255,256,257,258,259$. $260,272,273$.

Cypripedium (Lady's-slipper), 215. 288.

Czar of Russia, 327.

Daguerreotype of B., described, 183.

Dairy herd, 83,84 ; dairy work, 66 68, 200; Ayrshires and Durhams, 83 .

Dakota, 332; North, Bad lands of, 333.

Dam, 19; Dam One, 260.

Dana, Richard Henry, Jr., his Two Years before the Mast, 301.

Dandelion, 230, 237, 262, 310.

Darky. See Negro.

Dart, Nell, 77.

Dartmouth College, 12.

Darts and Cross-guns, 50, 51.

Darwin, Charles, his Naturalist's Voyage Round the World, 9.

Davis, Jefferson, 194.

Day dreams. See Traits and Characteristics of $\mathbf{B}$.

Deacon road, 32, 161; Deacon woods, or Beechwoods, 5, 35. $47,55,57,85,86,103,120$, $218,234,349$.

Dead Letter Offlce, 306.

Dobating clubs, $169,171$.

Deer, 87, 138; black-tailed, 334.

De Folx, Count, 294.

Delaware Blues, 208.

County, 14, 16, 123, 133, 145, $160,165,176,233$; map of, and history of. See Jay Gould.

river, 16, 41, 124, 316. See also Pepacton. 
Delhi, N. Y., 64, 129, 130.

De Loach, Richard J., 353; alluded to, 9,358 .

Desbrosses, 16; street, 16.

Desert. See Arizona.

Deyo, Chauncey B. ("Channy"), $243,310,311,320$.

Dick, Thomas, and his works, 174, 175.

Dick's hat-band, 38.

Dickens, Charles, his Great Expectations, 213.

Dimmick's Corners. See Arkville.

Distaff, 67, 101.

"Divine Abyss, The," 343. See also Grand Canyon of Colorado.

Dixie, 353.

Doctor, the Old. See Newkirk.

Dog, 6, 49, 85, 167, 294-300, 306, 316, 333; Wild puppies, 243; Cuff, $48,55,67,85,115,116$, 117, 136; Spot, 55, 118, 119; lige, 73; Rover, 294, 295 ; Rab, 294, 295, 299; Rose Mary Rose, 295, 296, 297, 299; Lark, 5, 296, 297, 299; Laddie, 298, 299; Ino, 298, 304; Nip, 299, 300; A Newfoundland, 73,299 ; Socrates, 313; Stickeen, 290.

Doggerel, 144, 145, 297.

Dog-churn, 67, 68, 200.

Dome of Capitol. See Capitol.

Dominican warbler. See Warbler.

Donelson, Fort. See Fort Donelson.

Donkey, 9.

Doon, the, 280.

Dove, mourning or turtle, 122, 288. See also Passenger pigeon.

Dowie, Old, 59, 60.

Down-renters. See Anti-rent War.

Downy. See Woodpecker.

"Dr. S- - partner in buckle project, 185, 186, 189, 190, 191.

Dred Scott Decision, 194.

Drewer, Old, 247, 249, 250.

Driving cows. See Cow.

Drum Taps. See Whitman.

Dry Brook, 7, 316, 317.

Dublin, 271.

Ducks, wild, 318; mallard, 334; ducking, 301.

Duke of Hell-roaring creek, 334.

Dumas, Alexandre, his Count of Monte Cristo, 198.

Dun heifer, the. See Dairy herd.

Durhams and Ayrshires. See Dairy herd.

Dutch oven, 66.

Dutchess County, 3, 220.

Dwarf cornel. See Cornel.

Dyeing, 100.

Eagle, 288.

Earle, Moses, 130.

Early, Gen. Jubal Anderson, 239. 241.

sweethearts. See Sweethearts.
East Branch. See Delaware river, also Pepacton, also Potomac.

India Oxen. See Oxen.

Orange, New Jersey, 187, 188, 191.

Eddy, Professor, first interested B. in botany, 214.

Edgerton, Constable, 131.

Edison, Thomas A., 9, 350, 351, $352,353,354,355$; quoted concerning phonograph, 352; on his deafness, 353 ; on his diet and habits, 353, 354, 355.

Mrs. Thomas A., 352.

Egg collectors, 6, 312.

Egypt, 9, 338.

Eighty-third birthday. See Yama Farms Inn.

El Capitan. See Yosemite.

Eliot, Walter, 146.

Elk, 331, 335 .

Elkhorn Ranch. See Roosevelt.

Ellsworth. See Hay.

"E. M. A. To." See Allen.

Emancipation Proclamation, 214.

Emerson, Ralph Waldo (Sage of Concord), 199, 200, 202, 208, 239 ; B.'s first reading of, 178; B.'s interest begins in, $182 ; B$.'s "Expression" attributed to $\mathbf{E}$., 198; his style simulates $\mathrm{E} ., 182$, 195, 198; E. at West Point, 216, 217 ; B. writing on $E, 260$; $E$. in Yosemite, 344 ; E. quoted, 182; indirectly, 344 .

Emerson and Thoreau, 360.

Encyclopædia Britannica, 147.

Enderlin, 77.

England, 11, 169, 261, 262, 339.

Englishman, a verdant, 265-271.

Equal Rights Association, 125, 126. See also Anti-rent War.

Esopus, N. Y., 274, 306; Esopus Valley, 342.

Essay on the Human Understanding. See Locke.

Eubranchipus vernalis. See Fairy Shrimp.

Europe, 272; B.'s first journey to, 261-271; second journey to, 280.

Eve, Mother, 113.

Evening Post, New York. See N. Y. Evening Post.

Evening primrose. See Primrose.

Everett, Edward, 187.

"Exhilarations of the Road, The," $234,235$.

Expedition to Alaska. See Harriman Alaskan Expedition.

"Expression," 195, 197, 198, 199. 209.

Ezekiel, Uncle. See Kelly.

Fabre, Jean Henri, 49.

Fairy shrimp (Eubranchipus vernalis), 308.

Faithful, Oid. See Yellowstone Park. 
Fanning-mill, 112.

Far' cow, the. See Dairy herd.

Far and Near, 324, 326; alluded to, 328.

Farmer's Almanac, 27.

Farragut, David Glascoe, 242.

Federal money system in 1790,12 , 230.

Fernow, Dr. B. E. (“Tree Chief”), 324.

Feudal system, relic of, 124, 125, 129.

Field and Study, 6.

"Fighting Joe." See Hooker.

Fireflies, giant, 329.

Firestone, H. S., 9, 353.

First Crossing of Greenland. See Nansen.

Finch, purple, 53; nest of, 337.

Fish, Horace, 191.

Fishing. See Trout and trout fishing. See also Suckers.

Flail, 111, 112. See also Threshing.

Flax, 100; flax-gathering, 76, 100, 101; flax-made shirts and trousers, $100,102$.

Flicker, or highhole, 47, 91, 233, 278, 337,360 .

Florida, 330.

Flowers, wild, study of, $214,215$.

Fly - catcher" "Gray - crested Fly catcher." See Nicknames of B.

Flying-fish, 329.

Flying grasshoppers. See Grasshopper.

Fog, lake of, 48.

Foot-paths. See School days of B.

Ford, Henry, 9, 330, 352, 354, 356; described by $B$. . 356; Ford car, B. drives, 9, 352, 354 .

Ford's Theatre, 244.

Forebears, B.'s, 11-21.

Fort Donelson. See Grant.

Henry. See Grant.

Stephen, 239, 241.

Sumter, 197, 244

Yellowstone. See Yellowstone Park.

Forty-niners. See Gold Fever.

Four Years in the White North. See MacMillan.

Fox, red, 7, 53, 118, 119, 302, 303, 323,351 ; fox-hunting, 118-119. "A White Day and a Red Fox," alluded to, 7 .

Fox sparrow. See Sparrow.

Fowler \& Wells, 173. See also Phrenology.

"Fragments from the Table of an Intellectual Epicure," 192.

France, 169, 271.

Franklin Institute, 153.

Patent. See Anti-rent War.

Sir John, 169.

Fraser river, 150

Fredericksburg, 205, 206, 210.

French Dictionary, 169.
French Revolution, The. See Carlyle.

French Zouaves (Les Enfants Perdus). See Zouaves.

Frog, 135; tree, 308; wood, 308; spawn of, 310. Pickering ( $\mathrm{Hy}$ la pickeringi). See Spring peepers.

Froissart, Jean, quoted, 294.

"From the Back Country" B.'s early nature essays, 199, 208, 209.

Fruit-gathering, 71-74. See also Berry-gathering, and Strawberries.

-farming, 273, 274, 276, 278, 279, $281,282,283,288,307,308$, $312,316$.

Fuertes, Louis Agassiz, 324.

Fugitive Slave Law, 19, 194.

Fulling-mill, 100.

Funk, Peter, auction of, 175.

Galium, 355.

Gall and Spurzheim. See also Phrenology.

Garland, Hamlin, 349

Garrattsville, N. Y., 181.

Garrison, William Lloyd, 244.

Gassette, Grace, artist, alluded to, 347.

Geesboro Point, 226.

Geese, picking, 75 ; wild, 90, 276.

General Training. See Training.

George W. Elder, The, 327.

Georgetown, 246, 260.

Georgia, 221, 330, 358

German newspapers, 357 ; traveller, 264-271; the German, 171.

Germany, 267, 356, 357.

Gettysburg, 218, 220; battle of, $166,218$.

Geysers. See Yellowstone Park.

Ghosts and hobgoblins. See Early Memories.

Giant stairs, 19, 48 .

Gilder, Richard Watson, 280.

Glaciers, 46, 105, 290. See also Alaska. See also Ice-Sheet.

Glacier Rock. See Yosemite.

Glasgow, 267.

"Glorious Fourth, A," 62-64, 142.

Goat, 247.

Goethe, Johann Wolfgang von, 264.

Goldfinch, 8, 102.

Gold Fever, 149, 150.

Good Hope Hill, 235.

"Goodness Essential to Greatness," a school-boy essay of B.'s, 179.

Goose-quills and pen-knives, 137, 180.

Gophers, singing, 334.

Gould, Jay, 115, 124, 126, 142, 143, $144,145,146,148$; sisters of, 142, 143; his History of Lelaware County, 124, 146; his map of Delaware County, 145, 146; quoted, 145. 
John, 115, 126, 127, 142, 143, 145. Grand Canyon of the Colorado ("The Divine Abyss"), 341, 342, 343, 346.

Grand Gorge, N. Y. (Moresville), 61,75 .

Grandparents, good story tellers, 11.

"Granny." See Kelly.

"Graphophone, Mr." See Edison.

Grant, Ulysses Simpson, 201, 219, 221, 227; at Forts Henry and Donelson, 201; early pictures of, 201; at Appomattox, 244; life plotted against, 244; his veterans, 240; visits vault in Treasury Department, 260; Grant and Colfax, 260.

"Granther." See Kelly.

Grapes and grape-culture. See Fruit-farming.

Grape thieves, anecdote of, 224.

Grasshopper, 48, 49, 95, 103. See also Locust.

Graves, a teacher of B,'s, 141.

Graveyard, 54.

Gray's Anatomy, 212.

"Gray-crested Fly-catcher." See Nicknames of $B$.

Great Britain, 279.

Great Expectations. See Dickens.

Great Smoky Mountains, 354.

Greece, 9.

Griffin's Corners, N. Y. (now Fleischmanns), 159.

Grindstone, 50, 82, 307.

Grinell, Dr. George Bird, 324

Grosbeak, pine, 307 .

Grouse, ruffed (Partridge), 53, 54, 57, 243, 288, 354; drumming of, 54 ; blue, 334 .

Growler. See Yellowstone Park.

Gulf of Mexico, 341.

Gull, sea, 59, 359 .

Hades, 350.

"Halcyon in Canada, The." See Canada.

Haleakala. See Hawaiian Islands.

Halleck, Gen. Henry Wager, 210.

Haman, 64.

Hamilton, Alexander, 230.

Hamlet, 289.

Hammond, Birch, 129.

Hancock, N. Y., 318.

Hanging at Delhi, 64.

"Hard Fare," 7.

Hardenburg Patent. See Anti-rent War.

Hardscrabble road, 32; creek, 63, 77,99 ; mountain, 180 .

Harpers Ferry, 188.

Harpersfield, N. Y., 153, 155; seminary at, 154, i55.

Harper's Magazine, 169; Weekly, 201.

Harriman Alaskan Expedition, 324 et seq.
E. H., and family, 324, 326; glacier, 325.

Harrison, William Henry, 29; Harrison-Tyler Campaign, 29-30.

Hartford, Michigan, 121.

Harvard University, 13, 326, 327; Glacier, 325

"Harvest Time," 208.

Haunted barn, 54.

Hawaii and Hawaiian Islands, 149 334, 340, 345; Maui, 345; music of, 345 ; poi, 345 ; taro, 345 . luau, 345; leis, 345; mangoes, 345; papaya, 345; "Holidays in Hawaii," 346; Haleakala, 345; Kilauea, 334, 345; Aloha. 346 .

Hawk, 25, 48, 50, 91, 215; marsh, 302 , 303; nest of, 303; tame, $302,303,304$.

Hawthorne, Nathaniel, 208.

Hay, John, 207

"Hay-barn Idyi," 347.

Haying, 48, 49, 109-111, 198, 199; hay-fleld etiquette, 109 .

Hay-barn Study, 347. See also Woodchuck Lodge.

Hedding Literary Institute, 167, $168,171,172,182$; studies at, 167, 168, 170. See also Ashland.

Hemlocks, the, 18, 52, 54, 96, 310. "In the Hemlocks," 310 .

Hendrickhokeau. See Indian.

Henry, Fort. See Fort Henry.

Hepatica, or liverwort, 215, 288.

Hercules, 55.

Hermit of Slabsides. See Nicknames of $B$.

Hermit thrush. See Thrush.

Herring, 60; scapping for, 301.

Hetch Hetchy Valley, 344 .

Hetchel, 67, 101; hetchelling, 101. 102.

Hewitt, Elder, 78, 79.

High Falls, N. Y., 184.

High hole. See Flicker.

High Island, 260.

Highland Falls, N. Y. See Buttermilk Falls.

"Hikes," rules for, 235.

Hill, Adama Sherman, his Rhetoric, 199.

His Transparency. See Roosevelt. Historic Boys Series. See Lincoln.

History of Delaware County. See Jay Gould.

Hobgoblins. See Early memories of $B$.

Hofer, Billy, 335, 336.

"Holidays in Hawail." See Hawailan Islands.

Holyoke College, 281.

"Hollow, The." See Roxbury.

Home, Old. See old Home.

Homestead. See Old Home.

Homer, alluded to, 322 .

Honey, 7, 72, 166; quests of, 302 , 
306, 312-316; ventures in, 211: bee-tree, 313, 314, 315 .

-bee, 6, 7, 90, 93, 175, 296, 306, $310,313,314,315,316,356$. Peggy Mel, 6. See also Bumblebee; "Idyl of the Honeybee, The," 296.

Honk Falls, 360 .

Honolulu. See Hawaiian Islands.

Hooker, Gen. Joseph, 210, 215, 227.

Hopi Point. See Grand Canyon of the Colorado.

Hornaday, William T., 351.

Horse, 6, 15, 16, 58, 79, 82, 115, 131 . $136,153,159,201,282,303$ $320,327,333,335,351$; wild horses, 342; horse-lot, 52; Prince, 6, 303; Prince and Pete, 154.

-plstol, 67, 128, 129.

Hound, 118, 312; Hound and Fox, 118-119, 303; Socrates and Spot. See Dog.

"Hounds of the sea." See Seal.

Houstonia, or bluet, 356.

Howard. See Ploutz.

Hubbard, Mother, 350; squashes, 350.

Huckleberry, 72, 291. See also Berry-picking.

"Hud." See Covert.

Hudson river, $17,56,59,174,223$, $273,274,275,276,277,278$, $280,285,290,292,295,296$, 298, 299, 301, 302; Valley of, $9,59$.

Hudson's Bay, 277

Hugo, Victor, 250.

Hull, Dr. Abram, 159, 160, 212 , 213.

Humboldt, lecture on. See Taylor.

Humming bird, nest of, 311; black, 329.

Hungarians, 140.

Hunt, Lelgh, referred to, 143

"Hunt for the Nightingale, A," 280

Hyde Park, N. Y., 275, 297, 298.

Hyla. See Spring peeper.

"Hymettus, Mt." See "Mt. Hymettus.

Ice-boat, 277 ; Ice-boating, '277; Iceharvesting, 277, 298.

"Ice Chief, Great." See Muir.

Ice-sheet, 105. See also Glaciers.

"Idyl of the Honey-bee, The," 296. See also Lark.

"Iliad of Rivers." See St. Lawrence.

Imperial Valley, California, motoring in, 359 .

"In the Hemlocks." See Hemlocks.

Independent, N. $\dot{Y}$. See N. Y. Independent.

India and Indian affairs, 339.

Indian name of $\mathrm{B}$. See Nicknames of $\mathbf{B}$.

Indian, the, 16, 124, 126, 139, 316 , 322 ; signatures of, 124.
"Indians," masquerade of, 126, 127, $128,129,130,131,132,133$. See also Anti-rent War.

Indies, 187; West. See West Indies. Indigo bird, or indigo bunting, 103 . Ink-wells, home-made, 137.

Inns of Court, $268,270$.

Ino. See Dog.

Internal Revenue. See Parnell.

Io, 103 .

Irish woman, 245; in market, 248.

Iron-wood tree, 46.

"Ivan." See Tyler.

“J. B." See Nicknames of B.

Jack Hazard Series. See Trowbridge.

Jack-in-the-pulpit, or wild arum, $288,355$.

"Jack-wax," or "lock-jaw," 92. See also Sugar-making.

Jacob and Rachael, 112.

Jacobs, Margaret, 13.

Jamaica, travels in, 328, 329, 330. See also "A Lost February."

Japanese, 345, 354 .

"Jaspar from Jersey," 220.

Jay, blue, 302.

Jenny Wren. See Wren.

Jersey City, New Jersey, 173.

"Jesse's Chopping," 314.

Joe, a Canadian guide, 322.

"John C." See Burroughs.

"John 0' Birds." See Nicknames of B.

"John o' Mountains." See John Muir.

Johns, Aaron, 258, 280, 321, 322.

Johnson, Andrew, 245

Dr. Samuel, 174, 175, 176, 178.

Johnson's Hollow, 63.

Johnston, Gen. Albert Sidney, 201. Gen. Joseph E., 221, 227.

Johnstown, N. Y., 67.

Jonah, 182, 305.

Jove, 321.

"Juba." See Squirrel. See also Scudder, Rube.

Junco or slate-colored snow bird, 86,347 ; nest of, $86,307,347$.

Kadiak, 326; bear, 326.

Kane, Dr. Elisha Kent, voyage in search of Franklin, 169

Keator, a Benjaminite. See Antirent War.

Kelly, Amy. See Burroughs.

Aunt Abby, 46.

Edmund ("Granther"), maternal grandfather of B.. 17-20, $28,31,54,95-96,103,104$, $105,166,240,241$.

Ezekiel ("Uncle Zeke"), 110.

"Zeke," the Anti-renter, 129.

John (Uncle John), 46, 105.

Lovina (Liscom), "Granny," the maternal grandmother of $B$., 17, 19. 
Martin (Uncle Martin), 28, 159. Kendall Green, 248.

Kennedy, Dr. See Gold Fever.

William Sloane, quoted indirectly, 280 .

Kentucky, 221; Kentucky " jane," 62.

Kettle Hill, 336.

"Kiested, Old," 125.

Kilauea. See Hawaiian Islands.

Kingbird, 48.

King George III, 123.

King's Cross, 265.

Kingston, N. Y., 174, 175, 190, 242.

Kitchen in B.'s home, 26-29, 65, $72,115$.

Kite and mouse, 50; kite, 51.

Knickerbocker Magazine, 212, 213.

Kossuth, Louis, 140; hats, 140.

La Jolla, California, 359.

Labrador, 277.

Laddie. See Dog.

Lady's-slipper. See Cypripedium.

La Fayette, Marquis de, 17.

"Laird of Woodchuck Lodge." See Nicknames of $B$.

Lake of fog. See Fog.

Lake St. John. See Canada.

Lamb, Charles, 178.

Lamb's Book of Life, 78.

Land of Nod, 29.

Lander, Gen. Frederick West, 204, 207.

Lapland Longspur. See Longspur. Lardner, Dionysius, 169.

Lark. See Dog.

Lark, prairie horned, 102; call of, 102; meadow, 278; skylark, 271 '

Leader, New York, 208.

Leaf and Tendril, 324.

Leases. See Anti-rent War.

Leaves of Grass. See Whitman.

Lectures, 147, 148, 149, 152, 178, 182.

Lee, Gen. Robert E., 209, 218, 221, 244.

Leedsville, N. Y., 220.

Leis. See Hawaiian Islands.

Les Enfants Perdus. See Zouaves. Letter Writer, 166.

Lexington, 6, 62, 63, 142.

Life. See Caricature of $\mathrm{B}$.

Life of Audubon. See Audubon.

Life of Washington. See Washington. George.

Lige. See Dog.

Lincoln, Abraham, 194, 197, 206. $207,211,214,242,243,244$ 245 ; re-election of, 242 ; second inauguration of, 243 ; assassination of, 244.

Mrs. Abraham, 207.

E. Foster, 5 .

Hospital, 248.

Linen, home-made. See Flax.

Llons, man-eating. See Africa.
"Liquid sunshine." See Hawaiian Islands.

Liscom, Lovina. See Kelly.

Literary Values, 328.

Literature and Nature, influence on B., 185.

Little Nature Series, compiled from B.'s works, 5 .

Liverpool, England, 262.

Liverwort. See Hepatica.

Locke, John, his Essay on the Human Understanding, 174, 175, 176.

"Lock-jaw" or "Jack-wax," 92. See also Sugar-making.

Locust, American (Schistocerca americana), 224

Locusts and Wild Honey, 328.

Lodi, bridge of. See Napoleon.

Log house of grandparents, 14, 15.

Log jail, 132.

London, 262, 263, 265, 266, 269 , 271 ; an adventure in, 264-271; Tower of, 261.

Lop-horn. See Dairy herd.

Long Island, N. Y., 274.

Long Woods, 142.

Longspur, Lapland. See Alaska.

Loom, 67, 101.

Loon, 323.

Lord's Prayer, 13.

"Loss and Gain," 194.

"Lost February, A," 328.

"Love-cote" at Riverby (renamed The Nest), 330.

Lowell, James Russell, 195, 196, 198.

"Lowland Mary." See Taft. See also Early sweethearts of $B$.

Luau. See Hawaiian Islands.

Lundy's Lane, hero of, 147. See also Rose Mary Rose.

Lundy, Neighbour, 296.

Lynx, 351.

MacKay, Emily. See Burroughs.

MacMillan, his Four Years in the White North, 9.

Magnetic needle, declination of, 11.

Mahomet, 177; Maine, 323; Maine woods, camping-out in, 279 , 323: "A Taste of Maine Birch," 322.

Malaspina Glacier, 325.

Mammoth Cave, Kentucky, 281.

Hot Springs. See Yellowstove Park.

Manasses, 204.

Manchuria, The, 345

Mandy. See Negro.

Mangoes. See Hawaii.

"Man - not - afraid - of - company." See Nicknames of $B$.

Maple, 4; maple sugar-making. See Sugar-making.

Margaretville, N. Y., 6, 320.

Mariposa Grove. See Yosemite.

"Mark Twain." See Clemens. 
Marlboro-on-the-Hudson, 196, 198.

Marlborough Road, 235.

Marmot. See Woodchuck.

Marsh marigolds, 96.

Marten, 16.

Martin, Amassa, 285, 290.

Martineau, James, 263.

Masquerade as Indians. See Antirent War.

Massachusetts, 12, 121, 239.

Mather, Cotton, 13.

Maui. See Hawalian Islands.

Meadow lark. See Lark.

McClellan, Gen. George B., 203. 205, 206, 207, 209, 210, 215.

McCulloch, Hugh, 229, 230, 231, 256; alluded to, 269; his Men and Measures of Half a Century, 221.

McDowell, Gen. Irvin, 205, 206.

Meade, Elder Jim, 80.

Meadow mouse. See Mouse.

Medicine, study of, 212, 213.

Meeker, Abe, 41.

Elihu, 39.

Henry, 33.

Meeker's Hollow, 100.

Meeting-house, óld Yellow, 77, 78.

Memories, Early. See John Burroughs.

Memphramagog, Lake, 322.

Men and Manners of Half a Century. See McCulloch.

Merino sheep, 58. See Sheep.

Merrimac river, 322.

Mesas, 342.

Methodists (Armenians), 78, 81, $167,183$.

Mexican War, 140, 147.

Mexico, 149.

Midges, 320.

Middletown, N. Y., 272, 273, 274.

Military Academy. See West Point.

Mill Brook, N. Y., 319, 320.

Millerites. See Adventists.

Milton, John, his Paradise Lost, 168. Miltonic architecture. See St. Paul's Cathedral.

Mink, 99

Mirror Lake. See Yosemite.

Missionary Ridge. See Thomas.

Mississippi river, 131, 221.

Mitten. See Fox-hunting. See also Early sweethearts.

Mobile. See Farragut.

Mojave Desert, 341.

Mole, 303.

Molly Cottontail. See Rabbit.

Monau. See Indian.

Mongoose, 329.

Montgomery Hollow, 63, 97, 347.

Montgomery, Mary, 62; alluded to, 58.

Moose, 87, 323, 331, 332, 337.

Moral Philosophy. See Wayland.

More Family Reunion, 357, 358.

More, Dr. James, 183.
Moresville, N. Y. See Grand Gorge. Mosquito, 170, 340 .

Mother Hubbard, 350.

Mourning dove. See Dove.

Mouse, meadow, in mountain lake, $5,25,50,52,118,303-304$; white-footed or deer, 86, 154: in Yellowstohe Park, 337.

Movies, 56, 152, 353.

Moving, A, 107, 108.

Moxie Lake. See Maine woods.

"Mrs. A-_." See Ashley.

"Mt. Hymettus" " 313.

Muir, John ("Great Ice Chief"), ("John o" Mountains"), 290", $324,325,340,341,342,343$, 344 ; at Slabsides, 289, 290; a monologist, 290, 333, 341, 342; quoted, $341,342,343,344,345$; Muir Glacier, 325, 326.

Helen, 342.

Mule, 333, 334, 342.

Muley cow, the. See Dairy herd.

Munroe, Kirk, his Cab and Caboose, 301.

Murphy the Indian Killer, 139.

Muskrat, 135, 302; fur of, 60.

Nansen, Fridtjof, his First Crossing of Greenland, 301.

Napoleon, at Bridge of Lodi, 146.

Nathan, "Uncle," $322,323$.

National Bank Examiner, 273, 279. 298, 307; Receiver, 272.

Banks inaugurated, 230, 231 ; Organization Division in Bureau of, 231.

Museum, 337.

Natural history in boyhood, 134, 135: true and false, 330,338 . See "Real and Sham Natural History." See also Nature Fakers.

Naturalist's Voyage round the World. A. See Darwin.

Nature, Vision of. See Nature Interlude.

a square deal with, $330,331$.

and literature, 185 .

"Nature and the Poets," 260.

Nature Fakers, 330, 331, 338.

Interlude in More Family Reunion, 357, 358.

Negro (or colored person), 19, 140. 206, 211, 226, 232, 247, 249, 250, 251, 256, 257, 258, 336: chicken thieves, 250, 251. See also" "Old Drewer" and "S-" the messenger.

Negro jingles, 140.

Nest, The, at Riverby, 278, 330 , 361 ; alluded to, 292,329 . See also "Love-cote."

Neversink, 98, 121, 320, 321.

New England, 352.

Newark, New Jersey, 188, 191.

Newburgh, N. Y., 190.

New Hampshire, 12, 321. 
New Jersey, 172, 173, 176, 186, 190.

Now York, N. Y. 16, 17, 146, 172 , $173,175,187,190,192,193$, $194,215,242,274$.

State, 13, 123, 190, 191.

Evening Post, $210,213$.

Independent, 194.

Tribune, 210.

Zoological Park, 326.

Newkirk, Dr., 38, 39.

Newspaper Row, 234.

Newt. See Salamander.

Niagara Falls, 281.

Nicholas, Emperor, 169.

Nicknames of B., "Bird Man, The," 6: "John o' Birds," 25, 290, $309,358,359,360$; " Oom John," 220, 290, 293, 332; "Jack," 228; "Hermit of Slabsides," 287; "Sage of Slabsides," 289; "Man-not-afraidof-Company," 288; "Uncle John," 311, 313, 314, 320; "J. B."' $318,319,320,321,322$, 323; "Laird of Woodchuck Lodge," 347; "Gray-crested Fly-catcher," 356.

Nig. See Cat.

Nightingale, the, 280; "A Hunt for the Nightingale," 280.

Nip. See Dog.

Noah, a modern, 316.

Noon-mark, 135.

North Carolina, 330.

Uriah ("Father North"), 186. $189,191$.

Ursula. See Burroughs.

woods. See Adirondacks.

"Notes of a Walker," 296.

Notes on Walt Whitman, Poet and Person, first book of B.'s, 258, 259.

Nova Zembla, 11.

O'Brien, Fitz James, 207.

Observation, the art of, 308; accuracy in, 330 .

Occoquan, 203.

Occultation of Venus. See Venus.

Ocean. See Atlantic Ocean. See also Pacific Ocean.

Ocean Grove, 281.

O'Connor, William D., 258; his The Carpenter, 258.

Old Clump, 14, 25, 39, 47, 72, 102 , $118,310,311,347$.

Drewer. See Drewer.

Faithful. See Yellowstone Park.

Home, B.'s birthplace, 7, 15, 25, $60,92,107,108,120,133,136$, $156,175,179,180,184,192$, 195, 198, 201, 202, 242, 310, 352 .

School Baptist. See Baptist.

Stone School-house ("Old Stone Jug" "), 32-34, 134.

-time Water system. See Water system.
Olive Mountain, 165.

N. $Y .159,176,211,212$.

Olney, Jesse, his Geography, 141.

Onteora, N. Y., 349, 352.

"Oom John." See Nicknames of B.

Orchard, apple, 7, 15, 38, 107, 108, $113,114,142,273,349,351$, 353 ; oriole. See Oriole.

Orchid. See Cypripedium.

Orchis, purple fringed, 53.

Oregon robin. See Robin.

Oriole, Baltimore, 283, 284 ; nest of, 311, 312; orchard, 290.

Ornithology, no books or collections accessible in B.'s boyhood and youth, 36, 236. See Audubon's Birds. See also Wilson.

Osler, William, Dr., 328.

Otsego Lake, 177.

Otter, 16, 303.

"Our Rural Divinity." See Cow.

Ouzel, water, 326.

Oven, brick, 27, 65; Dutch, 66; in stove, 72 .

bird, or wag tail, 287 ; nest of, 310 ; oven bird holder, 287.

Overcoat, family, 58, 100.

Owl, 54, 57, 58, 284, 288, 319; pigmy, 334.

Oxen, 14, 34, 39, 82, 87, 88, 90, 106, 108, 152, 162, 352; East India oxen, 329 .

Oxford, 263, 271.

Oyster Bay. See Roosevelt.

Pacific Ocean, 345; Coast, 150, 330. 340 : "Pacific Notes," 360.

Packard car, 354.

Paine, L. B., 180, 181.

Panama, Isthmus of, 150.

Panther. See Puma.

Papaya. See Hawaiian Islands.

Paradise Lost. See Milton.

Paring-machine, 72.

Paris, 263.

Parker's Aids, 210.

Parnell of Internal Revenue, 258.

Parris, Samuel, 13.

Partridge. See Grouse.

Pasadena, California, 359.

Passenger pigeon, or wild pigeon. See Pigeon.

Passumpsic, 322

Pastimes. See Chores.

Patent Office, 185.

Patroons. See Anti-rent War.

Peabody Museum, 326.

Pears, 73, 74, 76, 273. See also Fruit-gathering.

Peekamose, 321.

Peeper. See Spring peeper.

Peggy Mel. See Honey-bee.

Pelham, Mass., 12.

Pelican, 329, 359.

Pennsylvania, 105; oil regions of, 279.

Avenue. See Washington. 
Pennyroyal rock, 32, 148.

Pepacton, East Branch of the Delaware, $7,41,137,276,357$; voyage on, $7,279,316,317$; Pepacton, the book, 316; alluded to, 328.

Peru, Conquest of. See Prescott.

Petersburg, 239.

Petriffed Forests, 341, 342.

Pewee, nest of, 311.

"Philomath," an early pen-name of B., 176.

Philosophy of History. See Schlegel.

Phobe, or phœbe-bird, 90, 99. 287,360 ; nest of, 99 .

Phonograph, 56.

Phrenology, 142, 143, 166, 172; Phrenological Journal, 172. See also Fowler \& Wells, and Gall and Spurzheim. See also Combe.

Pickering frog. See Spring peepers. Pickett, Gen. George Edward, 218. Picking geese, 75.

Pietro, Cartaino Sciarrino, sculptor of B., 348.

Pig, 53, 66, 247; pigs of Irish woman, 248.

Pigeon, Passenger or wild, 119-122, 152 ; calls of, 120 ; Pigeon-hunting, $B$.'s first, 120.

Pigmy owl. See Owl.

Pine Knot, Virginia, 338, 339, 340.

Pioneer days, 14, 87, 104; shack of, 14.

Pipit or titlark, 359.

Pittsburg, 354 .

Plainfleld, New Jersey, 173.

Pleasant Pond, 323.

Pleasure wagon, 77,78 .

Plough-boy of the Catskills, 153, $154,155,162$.

Ploutz, Howard, 313, 314, 315.

Plover, golden, 326; ring-neck, 359; African, 338.

Podunk, 28.

Poi. See Hawaiian Islands.

Poke-berry, 53, 137.

Poland, author of a history of, 179.

"Polly kissed me." See Gould.

Polo, Illinois, 181, 183.

Poole's Index, 198, 199.

Pope, Alexander, 178.

Gen. John, 208, 209, 210.

Porcupine, 321.

Port Wells, 325.

Post, New York, Evening. See N. $Y$. Evening Post.

Pot-hunters and netters, 120-122. See also Passenger pigeon.

Potomac river, 203, 219, 233, 260; Army of, 203, 208, 221; East Branch of, 235.

Poughkeepsie, N. Y., 197, 211, 220, $275,290,296$.

Poultry, fancy, 83.

Prairie horned lark. See Lark.

Prattsville, N. Y., 64.
Prescott, William Hickling, his Conquest of Peru, 213.

Presidents of the United States. See Van Buren, Harrison, Lincoln, Johnson, Grant, Cleveland, Roosevelt.

Preston, Major, 40.

Sylvester, 80.

Primrose, evening, 356.

Prince. See Horse. Prince and Pete. See Horse.

William Sound, 325.

Puma, 16, 351.

Pump-logs. See Old-time water system.

Pumpkin, 27, 84, 103; for targets, $118,119$.

Pumpkintown, 235.

Purple finch. See Finch.

fringed orchis. See Orchis.

Pussy willow, 360.

Pyle, Howard, his Tales of Robinhood.

Quadrille, 156, 170, 171.

Quail or Bob White, 215

Quartermaster General's Department, 226, 227; quartermaster, $226,232$.

Queenstown, 271.

Quilling, 101, 102.

Quilting party, 76.

Rab. See Dog.

Rabbit, 5, 6, 302; jack, 342.

Raccoon. See 'Coon.

Rachael. See Jacob and Rachael.

Radcliffe, Glacier, 325.

Railroads, 55; Train of cars on, 59.

Raspberry ("rozberry"), 53, 72, 281,305 . See also Antwerp. See also Berry-gathering.

Rat. See Rocky Mountain.

Raven, 78.

"Real and Sham Natural History," 330. See also Nature Fakers.

Red Cross, 237. See also Whitman.

Red fox. See Fox.

Red Kill, N. Y., 19, 28, 95, 128, $129,459$.

Red men. See Indian.

Red woods, 290.

Regents Examination, 339.

Republicans, 258.

Revolutionary War, 13, 17, 123, 124,125 ; alluded to, 12 .

"Revolutions," early essay of B.'s quoted from, 182.

"Return of the Birds, The" (first named, "With the Birds"), 6, $225,226$.

Reynard. See Fox.

Rhetoric, 8, 148 . See also Hill.

Richmond, 244, 258; fall of, 244 ; "On to Richmond!" 197 .

Riverby, home of B., at West Park, N. Y., 4, 274, 276, 277, 284, 285, 287, 289, 291, 292, 309, 
$316,329,330,360$; stone house at, 274, 275, 276, 279, 289, 292, 294, 323. Riverby, the book, 274; alluded to, 328 .

Robin, 26, 32, 90, 234, 278, 284, 309 , 311, 329, 360; Oregon. See Alaska.

Rochester, N. Y., 38, 305, 353.

Rock. See Boyhood Rock.

Rock Creek, 243.

"Rock me to Sleep, Mother." See Akers.

"Rock of Chickamauga." See Thomas.

Rocky Mountains, 9; pack rat of, 338.

Rome, 9.

Rondout, N. Y., 189, 190; river, 185, 321; camping-out on, 279, 321.

Rose, boyhood. See Boyhood rose. Rose's Brook, 349.

Rose Mary Rose (Rover). See Dog.

Roosevelt, Theodore, 220, 225, 290, $291,292,293,330,331,332$, $333,335,336,337,339,340$; quoted, 220, 291, 292, 293, 332, $333,336,337,338,339,340$.

Theodore, Jr., 331.

Mrs. Theodore, 290, 291, 292. 293, 339, 340.

Rosecrans, Gen. William Starke, 221.

Rosendale, N. Y., 185.

Rossettis, The, 263.

Rotisserie, 4.

Rough Rider, 336.

Rover. See Dog.

Roxbury, N. Y. (birthplace of B.), $14,19,39,40,41,45,58,77$, $105,123,130,142,144,146$, $148,149,150,151,153,171$. $180,212,242,286,297,347$, 357: Academy at, 153; Pageant at, $357,358$.

Ruffed grouse. See Grouse.

Rundle Place. See Woodchuck Lodge.

"Rural Divinity, Our," 7, 84. See also Cow.

Russia, 169.

"S-_ coloured messenger, 256, 257,258

Sagamore Hill, 337, 338.

"Sage of Concord." See Emerson.

"Sage of Slabsides." See Nicknames of $B$.

Saguenay, 322.

Sailing vessels, 56.

Saint Elias Range, 325.

Saint-Pierre, Bernardin de, his Studies of Nature, 174, 175.

Salamander or newt, 90.

Salem Witchcraft, 13.

"Sally in our Alley." See Donkey.

"Sally, Silly." See Silly Sally.
Salting cattle and sheep, 102, 103.

Samson, 214.

Sandervatherverander. See Indian.

Sandwich Islands. See Hawaiian Islands.

San Francisco, 342, 344

San Joaquin Valley, 343.

Sap-bush. See Sugar-bush.

Sap-gathering. See Sugar-making.

Sato, 354.

Saturday Press, 192, 194, 199.

Saw-mill, 37, 38, 344 .

Schistocerca americana. See American locust.

Schlegel, Karl Wilhelm Friedrich von, his Philosophy of History, 195.

Schoharie County, 123.

School. See School days of $\mathbf{B}$.

Scot, the 141, 142, 183, 281, 341; lassie, 350; mason, $275,276$.

Scotia, The, 262.

Scotland, 142, 154, 280, 341.

Scott, Sir Walter, 264.

Gen. Winfleld, 147.

Scout. See Boy Scout.

Scudder, boys, 49; boys and girls, 142; Rube, 62, 63, 64, 142, 162 . Warren, 131, 142, 162; Milton, 142; Peace, 142; Deacon, 113. 142 ; orchard of, $113,142,273$; "Aunt" Debby, 77, 78; "Old Sam Scudder cow," 83 .

Sea gull. See Gull.

Seal, hair, 359.

Seal Islands, 326.

Seaman, Frank, alluded to, 360.

Seattle, 324, 327.

Sebastopol, 169.

Second Coming of Christ. See Adventists.

Second-hand book-stalls, 173, 174, 175.

Senate Offices, 243.

Sensitive plant, or "shame lady," 329.

Shacksville, N. Y., 77, 79, 138.

Shakespeare, William, quoted, 28, 178,271

"Shame lady." See Sensitive plant.

Shattega. See Black Creek.

Shawangunk Mountains, 330.

Sheep, 7, 77, 83, 86, 90, 99, 102 $152,200,286,327$; "Woolgathering," 7; Merino and South Down sheep, 58 ; pasture, 86,152 ; shearing of, 99,100 ; washing of, 99; mountain. 335,336 ; old ram, 67 .

Sheridan, Gen. Philip Henry, 241. 242.

Sheridan's Ride. See Sheridan.

Sherlock Holmes' methods, 314.

Sherman, Gen. William Tecumseh, $221,227,242$.

Sherman's March to the Sea. See Sherman.

Shiloh, news of battle of, 201. 
"Shine Eye." See Solitaire.

Shout, John, 136.

Shrike, or butcher bird, 311.

Shrimp, fairy. See Fairy shrimp.

Shylock, 145.

Sialia, The (Bluebird), 330.

Siamese twins. See Sugar-bush.

Siberia, 326, 327.

Sierras, the, 290.

Silly Sally. See Cat.

Silver, Tim, 184.

Simplifled Spelling League, 170.

Sir Mephitus. See Skunk.

Skating, 137, 277, 302.

Skiis, 337.

Skunk, 99, 135, 349, 350, 355; alluded to, 297.

cabbage, 360.

Skylark. See Lark.

Slabsides, near West Park, N. Y.. $4,20,285,286,287,288,290$, $291,292,294,300,303,308$, $313,324,328,331,345,347$.

Slate pencil and pencil-making, 33$34,135,136$.

Sled, home-made, 137.

Slide Mountain, camping-out on, 281.

Slough of Despond, 189.

Smith, boys and girls, 142; Alexander ("Sandy"), 140, 141, 142, 153; Dave, 140, 153; John, 142, 201; Thomas ("Tommy"), 142 ; Will, 142.

College, 281; Glacier, 325.

Smithsonian Institute, 232, 234, 310.

Snake, 41; black, 104, 105, 305; garter, 305; green, 305.

Snipe, 233.

"Snow Walkers, The," 7, 115; tracks in snow, 302, 303.

Snyder Hollow, camping-out in, 279.

Soap-making, 70-71.

Socrates, 217; the hound, 313.

Soledad. See La Jolla.

Solitaire ("Shine Eye"), in Jamaica, song of, 329; in Yellowstone Park (Townsend's), 334.

Somerville, New Jersey, 173.

Songs of Nature, edited by B., 327. of Three Centuries. See Whittier.

South Down Hills, 271; sheep, 58.

Southern Cross, 329.

Spanish American War. See Kettle Hill.

"Sparrowhawk." See Boy Scout.

Sparrow, the, 278, 310; vesper or grass finch, 47, 86, 103; song of, 87 ; nest of, 87 ; white throat. 234; fox, 234; English, 264, 304309 ; grasshopper, 310; Henslow's, 310; swamp, 310, 340: song, 326, 360; golden-crowned, 326; white-crowned, 337 ; Lincoln's, 340 .
"Speckled Trout," 6, 259. See also Trout.

"Spell of Yosemite, The." See Yosemite.

Spenser, Edmund, 178.

Spice-bush, 360.

Splder, 303; trap-door, 359.

Spinning-wheel, 30, 67, 100.

Spiritualism, B.'s first printed article, 176, 177.

Spokane, 337.

Spooks and hobgoblins. See Hobgoblins.

Spot, the hound. See Dog.

Spurgeon, Charles Haddon, 263.

Spurzhelm, Kaspar, his Phrenology, 174, 175. See also Phrenology.

Springs, 46, 63, 74, 91, 103, 135, 290, 295; Big Spring, 248, 272.

Spring peepers (Hyla Crucifer), 36$37,161,233,278,360$.

Squires, 'Ras ("Big Thunder"), 130.

Squirrel, gray, 5 ; red, $5,53,85,86$, $90,107,135,243,304,347,356$; dancing the "juba," $85,86$.

Squirrels and Other Fur Bearers, compiled from B.'s works, 5 .

St. Lawrence river, 322.

St. Louis, 122.

St. Paul, 332.

St. Paul's Cathedral, 262, 263.

Stars and Stripes, 204, 206.

Stamford in the Catskills, 14, 179, 180.

Statue of B. (The Seer), 348, 349.

Steamboat, 56, 58, 174, 285. See The Baldwin.

Steamship. See The Scotia, the George W. Elder, The Manchuria.

Steele, Deputy-sheriff, 130, 131. 132. See also Anti-rent War. Steele's tavern, 58.

"Steepside," alluded to, 25, 26, 84, $118,153$.

Stephen, Fort. See Fort Stephen.

Stickeen, 290. See also Muir.

Stocks and whipping-post, 16.

Stone, 105, 106; clearing fields of, $105,106,200$; stone-boat, 34, 106, 152; stone house at Riverby, selecting stone for, 274 , 275 .

Stone-wall, 25, 34, 51, 52, 82, 85, $90,96,105,106,120,199,297$, 313.

Stowe, Harriet Beecher, her Uncle Tom's Cabin, 140.

Stratford-on-Avon, 263

Stratton Falls, 49, 79, 135, 156.

Strawberry, the, 8, 47, 71, 72, 321; wood berries, 47; "Strawberries," the essay, 7, 8. See also Berry - gathering, and Fruit gathering

Street of Lost Time, 155.

Stripe Coat. See Chipmunk. 
Studies of Nature. See Saint Plerre. Suckers, fishing for, 137, 138; snaring for, 301 .

Sugar-bush, 15, 26, 52, 89, 90, 91, $92,93,153,278$.

-making, 15, 72, 89-94, 148, 159 , 198, 199, 201, 278, 359, 360: Sap-weather, 24.

Summit of the Years, alluded to, 328.

Sumter, Fort. See Fort Sumter.

Sunday walks, 233, 234, 236, 249 , 259.

Suppau. See Indian.

Susquehanna river, 16.

Swallow, the, 8; eave, 55; barn, in Alaska, 326.

Swan, 276.

Swathekeen. See Indian.

Sweethearts, early, 34-35, 157, 158, $159,167$.

Swimming-hole, 49, 110.

Swingle, 101; swingling-knife, 101.

Sylph, the, 290, 292, 293.

Syruping-off. 'See Sugar-making.

“T. R." See Roosevelt.

Taft, Mary (Lowland Mary), 94, $158,159,166,171$.

Tallow dip. See Candle-making.

'Tam o' Shanter, 280.

Tanager, scarlet, 30.

Taro. See Hawaiian Islands.

"Taste," anecdote concerning, 146, 147.

"Taste of Maine Birch." See Maine. Taylor, Bayard, his lecture on Humboldt, 191.

Tecumseh, 29.

Teeth-pulling, 39.

Telegraph, 55, 56.

Telephone, 55.

Tenallytown Road, 235.

Tennessee, 221.

Tennyson, Lord Alfred, 280.

Tern, Arctic, 326.

Terry clock, 27.

Terry's Tavern, 161.

Texas, 169 .

Thistle, 87; thistle-down, 142.

Thomas, Gen. George Henry, 221. 227; and Missionary Ridge, 227.

Thomas Lake (Beecher Lake), 320.

Thoreau, Henry David, 217, 282, 347. See also Emerson and Thoreau.

"Thought on Culture, A," quoted from, 193 .

Thrasher, brown, 36.

Three Rivers, Canada, 12.

Threshing, 111, 112.

Thrush, the, 234; hermit, 8, 36; veery or Wilson's, 85, 234; water, 288.

Timber wolf. See Wolf.

Time and Change, alluded to, 328.

Times (London), 267.

Tip-ups and pot-pies, 198.
"Tippecanoe and Tyler, too." See Tyler.

Toad, the, 278; song of, 278, 360 .

Tobacco, 336, 337, 353, 354.

Tody, green, 329.

Toledo Art Museum, statue of B. (The Seer), 348.

Tom Tinker. See Cat.

Tongore, N. Y., 160, 161, 162, 165 , $171,176$.

Tories, 18, 127, 128, 139.

Totem poles, 326 .

Tower Camp, 335

Townsend's solitaire. See Solitaire.

"Tragedies of the Nests, The," 6.

Training, General, and Company, 40.

Travels, 261 et seq., 279, 280, 281 , $321,322,324-327,328,329$. $330,331-337,338-346,353$, $354,358,359$.

Treasury Building, 231; Department. See Currency Bureau.

Tribune, New York. See N, Y. Tribune.

Trout and trout-fishing, 6, 9, 18, 19 , $53,89,95-98,135,138,152$, $195,272,306,310,311,320$, $321,322,334,360$. See also "Speckled Trout."

Trowbridge, John Townsend, his Jack Hazard Series, 301.

Trustee, school, $160,173,176,184$. $198,220$.

Tulip tree, 243.

Turkey, 250, 251; turkey gobbler, 338.

Turtle, 281.

Turtle dove. See Dove.

Two Years before the Mast. See Dana.

Tyler, John, 29. See also HarrisonTyler Campaign.

Ivan, 313, 314.

Ulster and Delaware railway, 208. county, 159, 160, 165.

Unadilla,' N. Ý., 132.

Unalaska, 326

"Uncle" Eli, 73.

Henry, 54 .

John. See Nicknames of B.

John and Aunt Abby. See Kelly.

Martin. See Kelly.

William and Aunt Nora, 38.

Nathan. See Nathan.

Sam. See United States.

Uncle Tom's Cabin. See Stowe.

Zeke. See Kelly.

Under the Apple Trees, alluded to, 328.

United States, 29, 122, 140, 149 , $214,219,241,261,272,333$, 339, 340; Uncle Sam, working for, 224-272, 273, 307, 310; U. S., fortunes of, paralleled with B.'s, 188, 189, 194, 214, 221, 227, 242. 
Universalism, 178, 179.

Universe, 56, 300. See Accepting the Universe.

Up-renters. See Anti-rent War.

V Street. See Washington.

Valley Forge, 17.

Van Buren, Martin, 29.

Vanderbilt, Mrs. Frederick, 299.

Van Dyke, Dick, 153, 154

Vassar College, 289; Glacier, 325 ; Wake Robin Club at, 288, 289.

Vault. See Currency Bureau; keeper of, 231, 232, 255-257.

Veery. See Thrush.

Venus, Occultation of, by moon, 173.

Vermont, 321, 331.

Verse-writing, 192, 312, 327; alluded to, 328.

Vesper sparrow. See Sparrow.

Vicksburg, 219, 220, 221.

Vineyard at Riverby, $278,279,281$. $282,283,284,287,288,307$. See also Fruit-farming.

Vireo, 302.

Virginia, 140, 221, 338; hills of, 232.

Voice of the People, 125. See also Anti-rent War.

Volcanoes. See Hawaiian Islands.

"Waiting," 212. See also Versewriting.

Wake Robin (first nature book of B.'s), 220, 231, 259, 261; Wake Robin Club at Vassar. See Vassar.

Walden Pond, 281, 282.

Waldorf-Astoria on wheels, 354 .

Walking-stick cut by beavers, 3 ; the animal named a, 308; a disguised gun, 236.

War. See Anti-rent War, Civil War, Crimean War, Mexican War, Revolutionary War, War of 1812, Spanish-American War, and World War.

Warbler, 219, 234, 340; blackthroated blue, $35,218,339$ hooded, 218; mourning ground, nest of, 311; black-poll, 339; prairie, 339; Wilson's blackcap, 339; pine, 339; Dominican. 337,338 ; spring migration of, 339 .

War Department. See Washington.

of Revolution. See Revolutionary War.

of $1912,17$.

Warming-pans, 67.

Washington, D. C., 146, 199, 201. $202,210,220,223,224,225$, $228,229,231,232,233,235$, $237,239,241,242,243,244$ $245,246,247,257,258,259$, $272,273,290,330,338,339$, 359.

George, 17, 241; Life of Washing- ton, 139, 140; Headquarters of, at Newburgh, N. Y., 190.

Wasps, white-faced, 302 .

Wasson, David A., 217.

Water ouzel. See Ouzel.

Water system, old-time, 74,75 .

Wayland, Francis, his Moral Philosophy, 168.

Ways of Nature, $328,330$.

Weasel, 52, 303.

Weaving, 102.

Wellesley Glacier, 325.

Westminster Review, 226.

West Indies, 12.

West Park, N. Y., home of B., 274, 309.

West Point, N. Y., 212, 216, 219; Military Academy at, 213, 217: Library at, 217; Collection of mounted birds at, 218. See also Audubon's Birds.

West Settlement, 18, 34, 115, 157; school in, 35, 126, 127, 128, $134,135,136,139,140,143$, $144,147,149,151,152,153$, 322.

Whigs, 29.

Whipping-post and Stocks, 16.

Whippoorwill, the, calls of, 288.

White-foot. See Dairy herd.

White House, 225, 234, 247, 337, 339.

White Star Line, 271.

White-throat. See Sparrow.

Whitman, Walt, 215, 216, 228, 234 , $236,237,245,258,279,281$ : B. first read Leaves of Grass, 192; W. described by Allen, 215, 216; W.'s Drum Taps, 216, 238; W.'s ministry to the soldiers, 216, 234, 237, 238, 239 , 245 ; B.'s flrst meeting with W., 228; W.'s comment on meeting B., 228; B.'s comment on meeting W., 228; a self-constituted Red Cross, 237, 238; W.'s tribute to the boys in blue and gray, 245; his "Captain, My Captain," quoted from, 245 : B.'s account of W. on hospital rounds, 237,238 ; $W$.'s letters to his mother, 238; W. and Sunday breakfasts, 248, 249; W. quoted, 228, 245; indirectly, 238. See also Notes on Walt Whitman, Poet and Person.

Whittier, John Greenleaf, his Songs of Three Centuries, 212.

Wide Awake, 301

Wild cat, 351; Wild Cat Pass, 63. Geese. See Geese.

honey. See Honey. See also Locusts and Wild Honey.

"Wild Life about my Cabin," 324.

pigeon. See Pigeon.

puppies. See Dog.

Wilderness. See Battle of the Wilderness. 
Wilkinson's Human Body, 213.

Willard's Hotel, 225, 234.

Wilson, Alexander, 236.

Windrow, 106.

Winter, sports in, 137, 138

"Wincer Neighbors," 7

Winter Sunshine, 231, 233.

Wisconsin, 341 .

Witches and wizards. See Salem Witchcraft. "Wizard." See Edison.

"With the Birds" (B.'s first bird article). See "The Return of the Birds."

Wittenberg, camping-out on, 281.

Wolf, timber, gray, 338.

Wolfe, Gen. James, 322.

Woman in White. See Collins.

Woodchuck, 9, 67, 85, 297, 348, 349; a coat made of skins, 348, 349 ; as food, 349.

Lodge, midsummer home of $B$. near Roxbury in the Catskills, $5,46,110,114,312,313,347$, $348,351,352,353$.

Woodcock, mating song of, 360 , 361 ; bleat of, 310,360 ; flight of, 361 .

Woodpecker, 51, 309; downy, 90, 278, 309; hairy, 309. See also Flicker.

Wool, Gen. John Ellis, 203.

Woolheitzer, 89.

Words, new, B.'s sensitiveness to, 146,147
Wordsworth, william, 280.

"Work and Wait" a school-boy essay of B.'s, 176; quoted from, 177.

World War, 9, 123, 356, 357.

Wren, house, 6 ; nest of, 312 ; Bewick's, 339, 340 .

Wright, Silas, Governor during Anti-rent War, 132

Writing lessons, $136,137$.

Yacht. See Sialia. See also The Sylph.

Yale University, B. takes honorary degree at. See Illustration; Glacier, 325.

Yama Farms Inn, 330, 360.

Yankees, 18; Yankee notions, 131.

"Yankee Doodle," 206.

Yarrow, 87, 262.

Yearly: Meetings, 79.

Yellowstone Park, 225, 331, 333, 334, 337 ; Fort, 334 .

Yoking up Oxen. See Oxen.

Yorktown, 206, 210.

Yosemite, 290, 341, 343, 344; "The Spell of Yosemite," 346 .

Young, Edward, 178.

Youth's Companion, 301.

"Zeke." See Kelly, the anti-renter. "Zeke Uncle." See Kelly.

Zouaves, French (Les Enfants Per$d u s), 205,206$. 


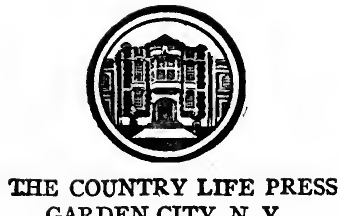

GARDEN CITY, N. Y. 





\section{YC147ry}

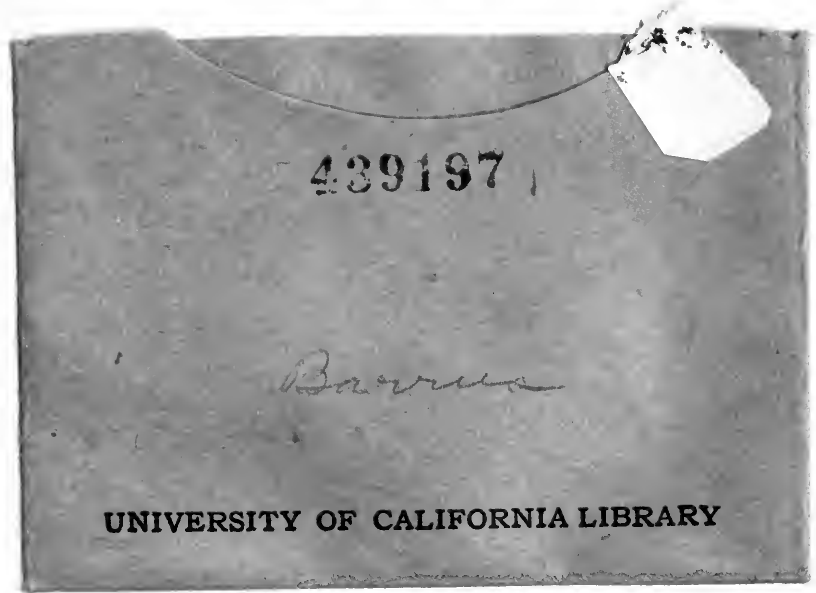




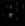

